Prepared in cooperation with the lowa Department of Natural Resources

\title{
Methods for Estimating Selected Low-Flow Frequency Statistics and Harmonic Mean Flows for Streams in lowa
}

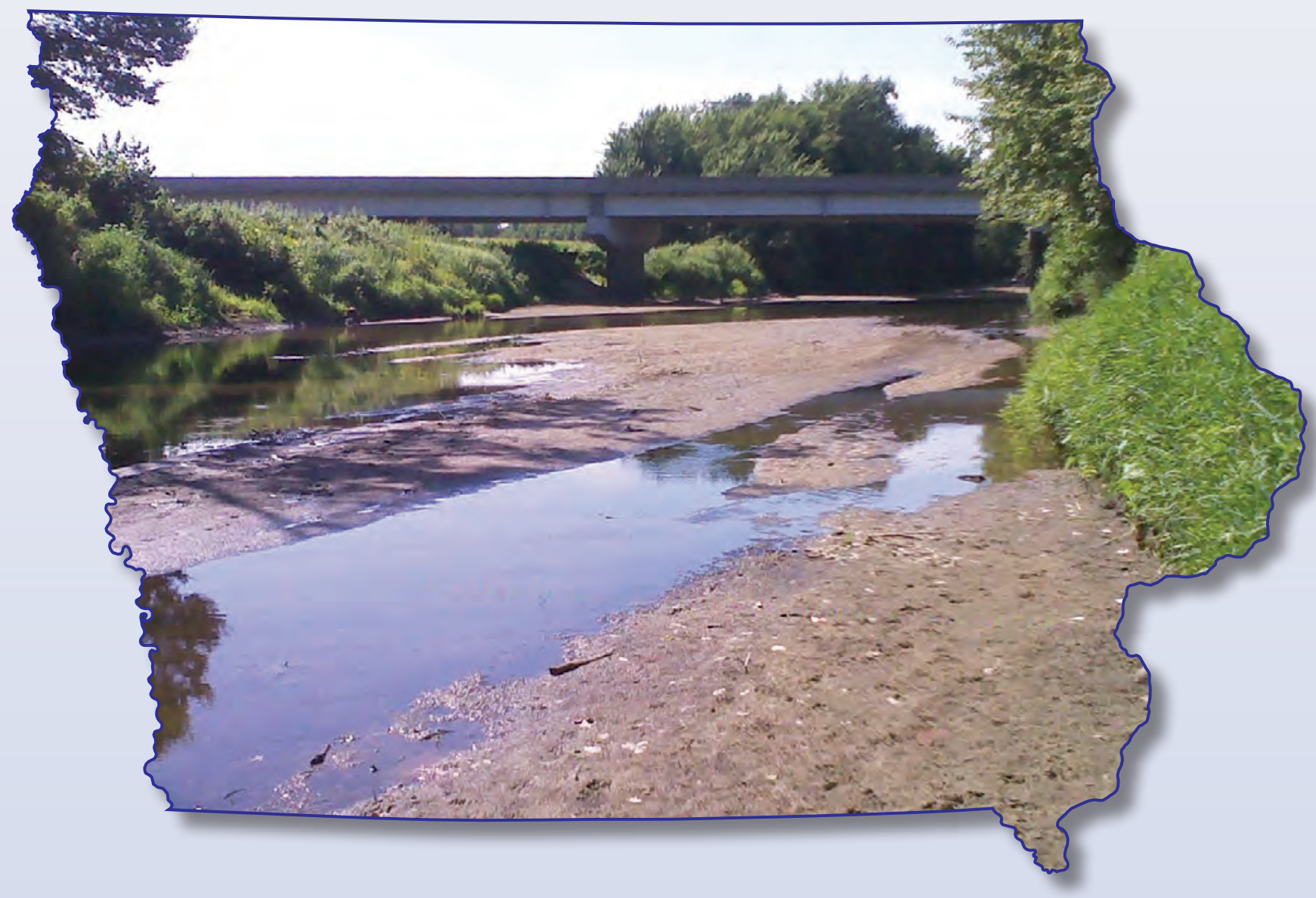

Scientific Investigations Report 2012-5171

Version 1.1, November 2017

U.S. Department of the Interior

U.S. Geological Survey 
Cover. Photograph of South Fork English River at State Highway 149 crossing north of South English, lowa. Photograph by U.S. Geological Survey. 


\section{Methods for Estimating Selected Low-Flow Frequency Statistics and Harmonic Mean Flows for Streams in lowa}

By David A. Eash and Kimberlee K. Barnes

Prepared in cooperation with the lowa Department of Natural Resources

Scientific Investigations Report 2012-5171

Version 1.1, November 2017 


\title{
U.S. Department of the Interior \\ RYAN K. ZINKE, Secretary
}

\section{U.S. Geological Survey William H. Werkheiser, Acting Director}

\author{
U.S. Geological Survey, Reston, Virginia: 2017 \\ First release: 2012 \\ Revised: November 2017 (ver 1.1)
}

\begin{abstract}
For more information on the USGS - the Federal source for science about the Earth, its natural and living resources, natural hazards, and the environment, visit http://www.usgs.gov or call 1-888-ASK-USGS.

For an overview of USGS information products, including maps, imagery, and publications, visit http://www.usgs.gov/pubprod

To order this and other USGS information products, visit http://store.usgs.gov
\end{abstract}

\footnotetext{
Any use of trade, firm, or product names is for descriptive purposes only and does not imply endorsement by the U.S. Government.

Although this information product, for the most part, is in the public domain, it also may contain copyrighted materials as noted in the text. Permission to reproduce copyrighted items must be secured from the copyright owner.
}

Suggested citation:

Eash, D.A., and Barnes, K.K., 2017, Methods for estimating selected low-flow frequency statistics and harmonic mean flows for streams in lowa (ver 1.1, November 2017): U.S. Geological Survey Scientific Investigations Report 2012-5171, 99 p., https://doi.org/10.3133/sir20125171. 


\section{Contents}

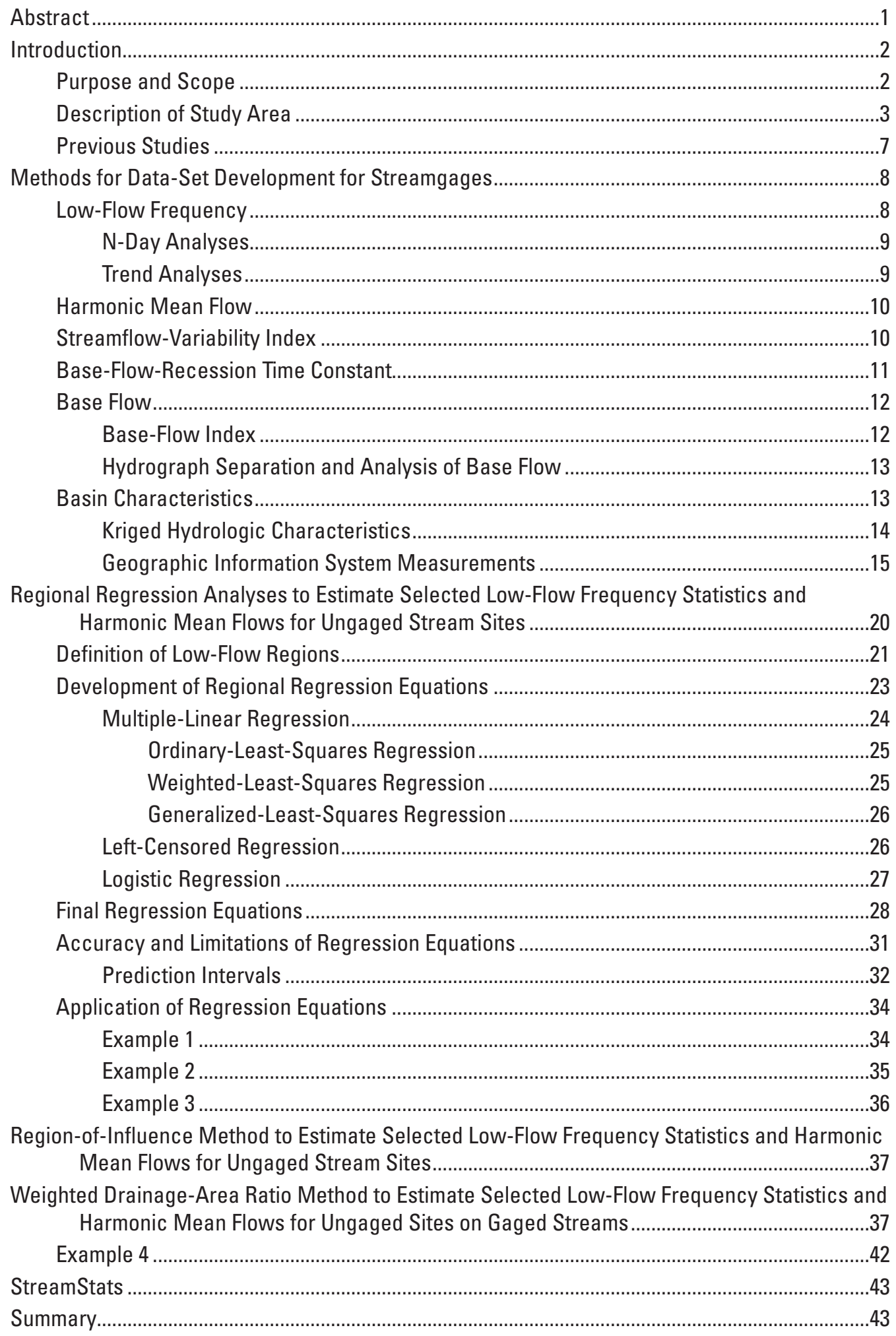


Acknowledgments 45

References Cited. .45

Appendix 1 ..... 95

\section{Figures}

1. Map showing location of low-flow regions and streamgages evaluated for regionalizing selected low-flow frequency statistics and harmonic mean flows in

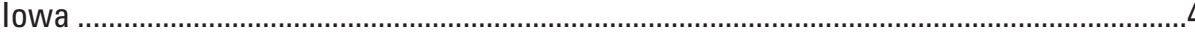

2. Map showing soil regions in lowa ...............................................................................

3. Map showing landform regions in lowa ..........................................................................6

4. Graph showing examples of flow-duration curves for streamgages Turkey River at Spillville, lowa (streamgage 05411600, map number 15), and South Fork Chariton River near Promise City, lowa (streamgage 06903700, map number 207)

5. Graph showing relation between base-flow index (BFI) and number of days (N) used to select an appropriate $\mathrm{N}$ value for $\mathrm{BFI}$ for the streamgage Chariton River near Chariton, lowa (streamgage 06903400, map number 205)

6. Graph showing semivariogram used to krige estimates of streamflow-variability index (STREAM_VAR) for lowa

7. Map showing streamflow-variability index (STREAM_VAR) isolines for lowa.......

8. Map showing annual base-flow-recession time constant (TAU_ANN) isolines for

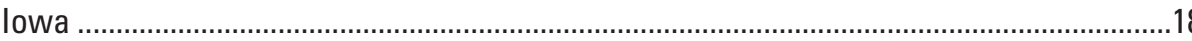

9. Map showing base-flow index (BFI) isolines for lowa.

10. Screenshot of the weighted-multiple-linear regression program (WREG) smoothing function for generalized-least squares (GLS) correlation of the time series of annual minimum 7-day mean flows as a function of distance between 81 streamgages in the southern region with 30 years of concurrent flow

11. Graph showing relation between the annual 7-day mean low flow for a recurrence interval of 10 years (M7D10Y) discharges computed from observed streamflow and those predicted from regression equations for low-flow regions in lowa

12. Graph showing relation of drainage-area ratio to absolute percent difference in annual 7-day mean low flow for a recurrence interval of 10 years (M7D10Y) statistics between estimates computed from observed streamflow and estimates derived from the drainage-area ratio method, from the weighted drainage-area ratio method, and from the regional regression equations.

\section{Tables}

1. Description of streamgages located in lowa and in neighboring States within a 50-mile buffer of lowa that were evaluated for use in the low-flow frequency and harmonic-mean-flow regressions for lowa

2. Selected low-flow frequency statistics and harmonic mean flows computed from observed streamflow and predicted from regional regression equations for streamgages evaluated in study..... 
3. Hydrologic characteristics computed from observed streamflow and basin characteristics measured for streamgages evaluated in study...

4. Summary of base-flow index (BFI) and hydrograph separation and analysis (HYSEP) of base-flow values computed from observed streamflow for streamgages in lowa.

5. Basin characteristics tested for significance in developing regression equations .......86

6. Model parameters used to fit semivariograms for kriged hydrologic characteristics...16

7. Cross-validation prediction errors of semivariogram models for kriged hydrologic characteristics.

8. Significant explanatory variables and predictive accuracies of preliminary statewide regression equations..

9. Streamgages removed from regional-regression analyses

10. Percentage of streamgages with estimates of zero flow computed from observed streamflow for selected low-flow frequency statistics and harmonic mean flows in each region of lowa

11. Regression equations for estimating selected low-flow frequency statistics and harmonic mean flows for unregulated streams in the northeast region of lowa

12. Regression equations for estimating selected low-flow frequency statistics and harmonic mean flows for unregulated streams in the northwest region of lowa ...........29

13. Regression equations for estimating selected low-flow frequency statistics and harmonic mean flows for unregulated streams in the southern region of lowa

14. Range of basin-characteristic values used to develop selected low-flow frequency and harmonic-mean-flow regression equations for unregulated streams in lowa ........88

15. Values needed to determine the 90-percent prediction intervals for estimates obtained from regional regression equations using covariance matrices in lowa.........89

16. Significant explanatory variables and predictive accuracies of preliminary region-of-influence equations in lowa.

17. Estimates of annual mean 7-day low flow for a recurrence interval of 10 years (M7D10Y) statistics computed from observed streamflow, the drainage-area ratio method, the weighted drainage-area ratio method, and regional regression equations; and absolute differences between the estimates computed from observed streamflow and estimates from the drainage-area ratio method, the weighted drainage-area ratio method, and regional regression equations for pairs of streamgages used to analyze the applicability of the drainage-area ratio and weighted drainage-area ratio methods for estimating M7D10Y statistics for ungaged sites on gaged lowa streams

18. Medians and standard deviations of absolute differences between annual mean 7-day low flow for a recurrence interval of 10 years (M7D10Y) statistics using observed streamflow and by using the drainage-area ratio method, the weighted drainage-area ratio method, and regional regression equations 


\section{Conversion Factors}

\begin{tabular}{|c|c|c|}
\hline Multiply & By & To obtain \\
\hline \multicolumn{3}{|c|}{ Length } \\
\hline inch (in.) & 2.54 & centimeter $(\mathrm{cm})$ \\
\hline foot $(\mathrm{ft})$ & 0.3048 & meter $(\mathrm{m})$ \\
\hline mile (mi) & 1.609 & kilometer $(\mathrm{km})$ \\
\hline foot per mile ( $\mathrm{ft} / \mathrm{mi})$ & 0.1894 & meter per kilometer $(\mathrm{m} / \mathrm{km})$ \\
\hline \multicolumn{3}{|c|}{ Area } \\
\hline square mile $\left(\mathrm{mi}^{2}\right)$ & 259.0 & hectare (ha) \\
\hline mile per square mile $\left(\mathrm{mi} / \mathrm{mi}^{2}\right)$ & 0.621 & kilometer per square kilometer $\left(\mathrm{km} / \mathrm{km}^{2}\right)$ \\
\hline square mile per mile $\left(\mathrm{mi}^{2} / \mathrm{mi}\right)$ & 1.609 & square kilometer per kilometer $\left(\mathrm{km}^{2} / \mathrm{km}\right)$ \\
\hline \multicolumn{3}{|c|}{ Flow rate } \\
\hline cubic foot per second $\left(\mathrm{ft}^{3} / \mathrm{s}\right)$ & 0.02832 & cubic meter per second $\left(\mathrm{m}^{3} / \mathrm{s}\right)$ \\
\hline \multicolumn{3}{|c|}{ Hydraulic conductivity } \\
\hline inch per second (in/s) & 25,400 & micrometers per second $(\mu \mathrm{m} / \mathrm{s})$ \\
\hline
\end{tabular}

\section{Acronyms}

$\begin{array}{ll}\text { Adj-R } & \text { Adjusted coefficient of determination } \\ \text { AMLE } & \text { Adjusted maximum-likelihood estimation } \\ \text { ANNIE } & \begin{array}{l}\text { USGS Interactive Hydrologic Analyses and Data Management computer } \\ \text { program }\end{array} \\ \text { BFI } & \text { Base-flow index } \\ \text { DAR } & \text { Drainage-area ratio } \\ \text { DEM } & \text { Digital elevation model } \\ \text { DRG } & \text { Digital raster graphics } \\ \text { DRNAREA } & \text { GIS-determined drainage area } \\ \text { DRNFREO } & \text { Drainage frequency } \\ e & \text { Base of the natural logarithm, approximately equal to 2.7183 } \\ \text { GIS } & \text { Geographic Information System } \\ \text { GLS } & \text { Generalized-least-squares regression } \\ \text { GRol } & \text { Geographic space Rol } \\ \text { HRol } & \text { Hybrid Rol, a combination of PRol and GRol } \\ \text { HUC } & \text { Hydrologic unit code } \\ \text { HYSEP } & \text { Hydrograph separation and analysis } \\ \text { IDNR } & \text { lowa Department of Natural Resources } \\ \text { IOWDM } & \text { USGS Input and Output for a Watershed Data Management (WDM file) } \\ & \text { computer program }\end{array}$


KSATSSUR Average soil permeability or saturated hydraulic conductivity of soil

LOWESS Locally-Weighted Scatter plot Smoother

M1D10Y Annual 1-day mean low flow for a recurrence interval of 10 years

M1D10Y1012 Seasonal (October through December) 1-day mean low flow for a recurrence interval of 10 years

M7D2Y Annual 7-day mean low flow for a recurrence interval of 2 years

M7D10Y Annual 7-day mean low flow for a recurrence interval of 10 years

M7D10Y1012 Seasonal (October through December) 7-day mean low flow for a recurrence interval of 10 years

M30D5Y Annual 30-day mean low flow for a recurrence interval of 5 years

M30D10Y Annual 30-day mean low flow for a recurrence interval of 10 years

MEV Model error variance

MLE Maximum-likelihood estimation

MSE Mean-square error

NED National elevation dataset

NHD National hydrography dataset

NPDES National Pollution Discharge Elimination System

NRCS Natural Resources Conservation Service

NWIS National Water Information System

OLS Ordinary-least-squares regression

PAM Partitioning around medoids

PRC8 Mean August precipitation

PRISM Parameter-elevation Regressions on Independent Slopes Model

PRol Independent or predictor-variable space Rol

Pseudo- $\mathrm{R}^{2} \quad$ Pseudo coefficient of determination

$P_{\text {zero }}$

Probability of the low-flow frequency statistic being equal to zero

$\mathrm{OAH} \quad$ Harmonic mean flow

RMSE Root mean square error, also referred to as SEE

Rol Region of influence

RRE Regional regression equation

RSD Relative stream density

SEE Average standard error of estimate, also referred to as RMSE

SEM Standard error of model

SEP Average standard error of prediction

SOILASSURGO Hydrologic soil type A

SOILBSSURGO Hydrologic soil type B 


$\begin{array}{ll}\text { SOILCSSURGO } & \text { Hydrologic soil type C } \\ \text { SSURGO } & \text { NRCS Soil Survey Geographic database } \\ \text { StreamStats } & \text { USGS Web-based GIS tool (http://water.usgs.gov/osw/streamstats/index.htm/ } \\ \text { STREAM_VAR } & \text { Streamflow-variability index } \\ \text { SWSTAT } & \text { USGS Surface-Water Statistics computer program } \\ \text { TAU_ANN } & \text { Annual base-flow-recession time constant } \\ \text { TMDL } & \text { Total Maximum Daily Load } \\ \text { U } & \text { Covariance matrix } \\ \text { USDA } & \text { U.S. Department of Agriculture } \\ \text { USEPA } & \text { U.S. Environmental Protection Agency } \\ \text { USGS } & \text { U.S. Geological Survey } \\ \text { UTM } & \text { Universal Transverse Mercator } \\ \text { VIF } & \text { Variance inflation factor } \\ \text { WBD } & \text { Watershed boundary dataset } \\ \text { WDAR } & \text { Weighted drainage-area ratio } \\ \text { WLA } & \text { Waste-load allocation } \\ \text { WLS } & \text { Weighted-least-squares regression } \\ \text { WREG } & \text { Weighted-multiple-linear regression program }\end{array}$




\title{
Methods for Estimating Selected Low-Flow Frequency Statistics and Harmonic Mean Flows for Streams in lowa
}

\author{
By David A. Eash and Kimberlee K. Barnes
}

\section{Abstract}

A statewide study was conducted to develop regression equations for estimating six selected low-flow frequency statistics and harmonic mean flows for ungaged stream sites in Iowa. The estimation equations developed for the six low-flow frequency statistics include: the annual 1-, 7-, and 30-day mean low flows for a recurrence interval of 10 years, the annual 30-day mean low flow for a recurrence interval of 5 years, and the seasonal (October 1 through December 31 ) 1- and 7-day mean low flows for a recurrence interval of 10 years. Estimation equations also were developed for the harmonic-mean-flow statistic. Estimates of these seven selected statistics are provided for 208 U.S. Geological Survey continuous-record streamgages using data through September 30, 2006. The study area comprises streamgages located within Iowa and 50 miles beyond the State's borders. Because trend analyses indicated statistically significant positive trends when considering the entire period of record for the majority of the streamgages, the longest, most recent period of record without a significant trend was determined for each streamgage for use in the study. The median number of years of record used to compute each of these seven selected statistics was 35. Geographic information system software was used to measure 54 selected basin characteristics for each streamgage. Following the removal of two streamgages from the initial data set, data collected for 206 streamgages were compiled to investigate three approaches for regionalization of the seven selected statistics. Regionalization, a process using statistical regression analysis, provides a relation for efficiently transferring information from a group of streamgages in a region to ungaged sites in the region. The three regionalization approaches tested included statewide, regional, and region-of-influence regressions. For the regional regression, the study area was divided into three low-flow regions on the basis of hydrologic characteristics, landform regions, and soil regions. A comparison of root mean square errors and average standard errors of prediction for the statewide, regional, and region-of-influence regressions determined that the regional regression provided the best estimates of the seven selected statistics at ungaged sites in Iowa.
Because a significant number of streams in Iowa reach zero flow as their minimum flow during low-flow years, four different types of regression analyses were used: left-censored, logistic, generalized-least-squares, and weighted-least-squares regression. A total of 192 streamgages were included in the development of 27 regression equations for the three low-flow regions. For the northeast and northwest regions, a censoring threshold was used to develop 12 left-censored regression equations to estimate the 6 low-flow frequency statistics for each region. For the southern region a total of 12 regression equations were developed; 6 logistic regression equations were developed to estimate the probability of zero flow for the 6 low-flow frequency statistics and 6 generalized leastsquares regression equations were developed to estimate the 6 low-flow frequency statistics, if nonzero flow is estimated first by use of the logistic equations. A weighted-least-squares regression equation was developed for each region to estimate the harmonic-mean-flow statistic. Average standard errors of estimate for the left-censored equations for the northeast region range from 64.7 to 88.1 percent and for the northwest region range from 85.8 to 111.8 percent. Misclassification percentages for the logistic equations for the southern region range from 5.6 to 14.0 percent. Average standard errors of prediction for generalized least-squares equations for the southern region range from 71.7 to 98.9 percent and pseudo coefficients of determination for the generalized-least-squares equations range from 87.7 to 91.8 percent. Average standard errors of prediction for weighted-least-squares equations developed for estimating the harmonic-mean-flow statistic for each of the three regions range from 66.4 to 80.4 percent.

The regression equations are applicable only to stream sites in Iowa with low flows not significantly affected by regulation, diversion, or urbanization and with basin characteristics within the range of those used to develop the equations. If the equations are used at ungaged sites on regulated streams, or on streams affected by water-supply and agricultural withdrawals, then the estimates will need to be adjusted by the amount of regulation or withdrawal to estimate the actual flow conditions if that is of interest. Caution is advised when applying the equations for basins with characteristics near the applicable limits of the equations and for basins located in karst topography. A test of two drainage-area ratio methods 
using 31 pairs of streamgages, for the annual 7-day mean lowflow statistic for a recurrence interval of 10 years, indicates a weighted drainage-area ratio method provides better estimates than regional regression equations for an ungaged site on a gaged stream in Iowa when the drainage-area ratio is between 0.5 and 1.4.

These regression equations will be implemented within the U.S. Geological Survey StreamStats web-based geographic-information-system tool. StreamStats allows users to click on any ungaged site on a river and compute estimates of the seven selected statistics; in addition, 90-percent prediction intervals and the measured basin characteristics for the ungaged sites also are provided. StreamStats also allows users to click on any streamgage in Iowa and estimates computed for these seven selected statistics are provided for the streamgage.

\section{Introduction}

Knowledge of the magnitude and frequency of low flows for streams is fundamental for water-supply planning and design, waste-load allocation, reservoir storage design, and maintenance and quantity and quality of water for irrigation, recreation, and wildlife conservation. Low-flow statistics indicate the probable availability of water in streams during times when conflicts between water supply and demand are most prevalent. Because of this, low-flow statistics are needed by Federal, State, and local agencies for water-quality regulatory activities and water-supply planning and management. These statistics can be used as thresholds when setting wastewatertreatment plant effluent limits and allowable pollutant loads to meet water-quality regulations. Low-flow statistics can be used by commercial, industrial, and hydroelectric facilities to determine availability of water for water supply, waste discharge, and power generation. Low-flow statistics also can be used in ecological research. Low-flow conditions can disturb ecosystems and create biological responses and changes in habitat such as reduced populations of aquatic species and shifts in the relative distribution of species (Miller and Golladay, 1996).

Currently (2012), 384 stream reaches in Iowa were designated as impaired (Category 5 of the State's Section 303(d) list that exceed specific water-quality and/or biological criteria) (Iowa Department of Natural Resources and the U.S. Environmental Protection Agency, 2010). These stream reaches are scheduled to have pollutant loads analyzed and maximum loading rates established by Total Maximum Daily Load (TMDL) assessments (U.S. Environmental Protection Agency, 2011). Reliable estimates of expected streamflow are needed for specific periods of the year when determining the maximum allowable load of a pollutant in a stream. Estimates of expected streamflow are especially important for low-flow periods when agencies need to determine waste-load allocations (WLAs) for National Pollution Discharge Elimination
System (NPDES) discharge permits for municipalities, industries, and other entities with facilities that release treated wastewater into a stream. A WLA is the loading capacity or maximum quantity of a pollutant each point-source discharger is allowed to release into a particular stream. WLAs are used to establish water-quality-based limits for point-source discharges.

Seasonal low-flow statistics are used by Iowa Department of Natural Resources (IDNR) for setting thresholds for controlled discharges from wastewater-treatment plants during the period October through December. Controlled discharges from wastewater-treatment plants are only allowed twice a year, one in the spring and another in the fall. Because streamflows in Iowa are typically lower in the fall than in the spring, fall is the critical season used to develop discharge limits for these facilities (Connie Dou, Iowa Department of Natural Resources, written commun., 2007).

The U.S. Geological Survey (USGS) operates a network of streamgages in Iowa that provides streamflow data for a variety of purposes, and low-flow frequency statistics and harmonic-mean flows can be calculated from streamflow data collected at these locations. However, it is not possible to operate streamgages at every location; therefore, methods are needed for estimating low-flow frequency statistics and harmonic mean flows at ungaged stream sites. In response to the need to update and improve the accuracy of estimates of low-flow frequency statistics and harmonic mean flows for ungaged stream sites in Iowa, the USGS, in cooperation with the IDNR, initiated a statewide study in 2007. This study updates selected low-flow frequency and harmonic-mean-flow estimates for streams in Iowa with data collected through September 30, 2006. Major components of the study included (1) computing seven selected statistics at 208 continuousrecord streamgages within Iowa and adjacent States with at least 10 years of streamflow record using the longest, most recent period of record through September 30, 2006, without a significant trend; (2) measuring 54 basin characteristics for each streamgage that include hydrologic-characteristic measurements from five kriged grids developed for the study area; (3) developing 27 regional regression equations to estimate 7 selected statistics at ungaged stream sites based on basin characteristics; and (4) testing two drainage-area ratio methods to determine if either method provides better estimates for a selected low-flow frequency statistic for ungaged sites on gaged streams in Iowa compared to regional regression estimates and to determine the appropriate range of drainage-area ratios to use with the method.

\section{Purpose and Scope}

Regression equations for estimating selected low-flow frequency statistics and harmonic-mean flows were developed for use in Iowa and are described in this report. The regression equations relate selected low-flow frequency statistics and harmonic mean flows to physical and hydrologic characteristics 
of drainage basins. In addition, the regression equations developed from this study also are included in the USGS StreamStats Web-based geographic information system (GIS) tool (http://water.usgs.gov/osw/streamstats/index.html). StreamStats allows users to obtain selected streamflow-statistic estimates, upstream drainage-basin characteristics, and other information for user-selected stream sites. Using a GIS-based interactive map of Iowa, the user can 'point and click' on a stream site and StreamStats will delineate the basin boundary upstream from the selected site. The user also can 'point and click' on USGS streamgages and receive selected streamflow statistics and other streamgage information.

This report presents 27 regional regression equations that can be used to estimate 7 selected statistics for ungaged sites on unregulated streams in Iowa. Sixteen of the equations can be used to estimate low-flow frequency statistics for annual 1-, 7-, and 30-day mean low flows for a recurrence interval of 10 years (M1D10Y, M7D10Y, and M30D10Y) and an annual 30-day mean low flow for a recurrence interval of 5 years (M30D5Y). Eight of the equations can be used to estimate low-flow frequency statistics for seasonal (October 1 through December 31) 1- and 7-day mean low flows for a recurrence interval of 10 years (M1D10Y1012 and M7D10Y1012). Three of the equations can be used to estimate the harmonic-meanflow statistic. Low-flow frequency and harmonic-mean-flow statistical names used in this report were selected to maintain consistency with names used within StreamStats (http://water. usgs.gov/osw/streamstats/StatisticsDefinitions.html).

The equations were developed using selected low-flow frequency statistics and harmonic-mean flows computed for 192 continuous-record streamgages unaffected by regulation or diversion that are located in Iowa and in adjacent States within a 50-mile (mi) buffer of Iowa (all gaged drainage basins are within the buffer). Selected low-flow frequency statistics and harmonic mean flows computed for 208 streamgages are presented in this report. Low-flow frequency statistics and harmonic mean flows for these 208 streamgages were computed using streamflow data collected through September 30, 2006, and were computed using 10 or more years of record. Because significant positive trends in annual low flow were found when considering the entire period of streamflow record for the majority of the streamgages included in this study, low-flow frequency statistics and harmonic mean flows were computed for each streamgage using the longest, most-recent period of record without a significant trend in low flow. The accuracy and limitations of the regression equations and the methodology used to develop the equations are described in the report.

\section{Description of Study Area}

The study area (fig. 1) includes the entire State of Iowa and adjacent areas within a 50-mi buffer of Iowa in the neighboring states of Illinois, Minnesota, Missouri, Nebraska, South Dakota, and Wisconsin. A map of Iowa soil regions created by the National Cooperative Soil Survey and the Natural Resources Conservation Service (NRCS) is shown in figure 2 (ftp://ftp-fc.sc.egov.usda.gov/IA/technical/ IowaSoilRegionsMap.html). There are 10 landform regions in the State, each having distinctive topography and geology (fig. 3).

The Mississippi and Missouri River Alluvial Plains and Iowa-Cedar Lowland (formerly included in the Mississippi Alluvial Plain; Prior, 1991) landform regions make up a small part of Iowa; these regions are characterized as broad flatfloored flood plains underlain by water-transported deposits (Prior and others, 2009).

The Southern Iowa Drift Plain is characteristic of an older, postglacial landscape that has eroded to form a steeply to gently rolling topography and a well-established drainage system (Prior, 1991). The region formed as a result of repeated continental glacial advances across southern Iowa, during which the bedrock surface of the uplands was smoothed and the valleys were filled with thick deposits of glacial till. Periods of glaciation were followed by interglacial periods of erosion. The sequence of repeated glacial scour and fill formed a nearly level drift plain across southern Iowa. The topography of southern Iowa developed as a result of the erosion of this drift plain; common terrain characteristics are integrated drainage networks, stepped erosional surfaces, and exposed bedrock in the deeper alluvial valleys (Prior, 1991). Nearly all of the upland soils of southern Iowa are formed from moderate deposits of wind-blown loess that subsequently covered the glacial tills. Soils in southern Iowa are generally characterized as loess over clay-loam till and clay paleosol; thickness of loess deposits in southern Iowa range from 6 to over 16 feet (ft) (Oschwald and others, 1965).

The Des Moines Lobe landform region is characteristic of a young, postglacial landscape that is unique with respect to the rest of the State (Prior, 1991). This region generally comprises low-relief terrain, accentuated by natural lakes, potholes, and marshes, where surface-water drainage typically is poorly defined and sluggish. Soils of this region generally consist of friable, calcareous loam glacial till with thick deposits of compact, uniform pebbly loam (Oschwald and others, 1965; Prior, 1991).

The Iowan Surface landform region is a low-relief plain with well-established, low-gradient drainage networks. Topography of this region appears slightly inclined to gently rolling with long slopes and open views to the horizon (Prior 1991). Soils of this region are characterized as thin, discontinuous loess or loam and clay loam over glacial drift (Prior, 1991; Oschwald and others, 1965).

The Northwest Iowa Plains landform region is similar to the Iowan Surface landform region in terms of erosional history and overall appearance. The topography of this region is a gently rolling landscape of low, uniform relief. A wellestablished branching network of streams covers this region, providing effective drainage and a uniformly ridged land surface (Prior, 1991). Most of the valleys are wide swales that merge gradually with long, even slopes up to broad, gently rounded basin divides. Windblown loess is abundant and 


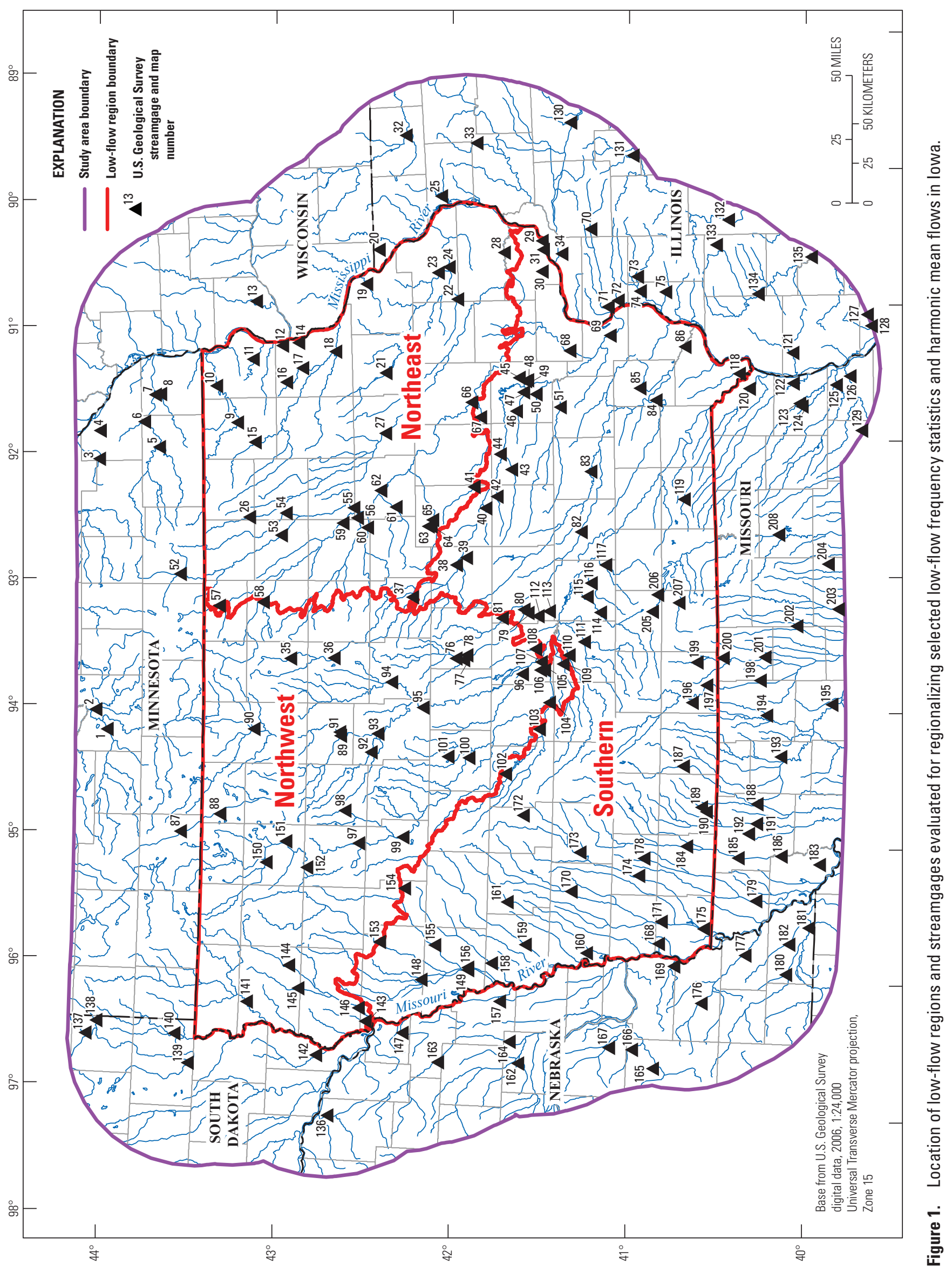


nearly continuous across the Northwest Iowa Plains; depth of the mantle varies generally from 16 to $4 \mathrm{ft}$ in a southwest to northeast direction across the region. Soils in this region are characterized as loess over clay loam till (Oschwald and others, 1965).
The East-Central Iowa Drift Plain is similar to the Southern Iowa Drift Plain and was formerly included as part of the Southern Iowa Drift and the Iowan Surface but is now considered a separate landform because of its uniqueness (Prior and others, 2009). The East-Central Iowa Drift Plain has bedrock

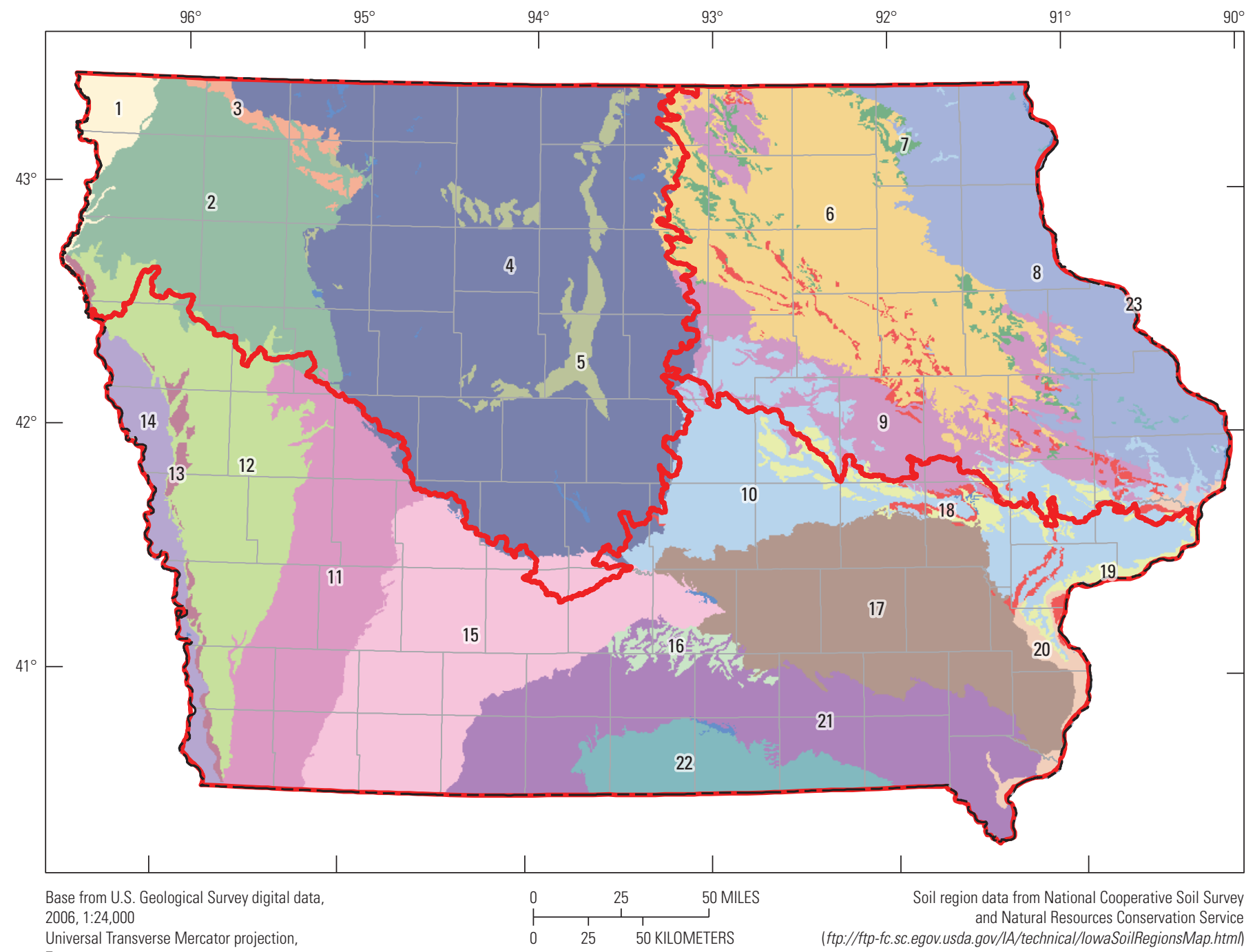
Zone 15

\section{EXPLANATION}

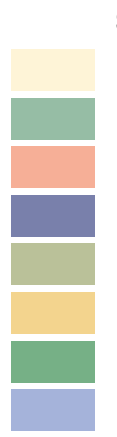

Soil region

1 Semi Arid Loess over Glacial Till

2 Loess (Northwest lowa)

3 Tazewell Glacial Til

4 Loamy Wisconsin Glacial Till

5 Clayey Lacustrine Deposits

6 Loamy Glacial Till

7 Shallow to Bedrock

8 Loess with Bedrock Outcrops
9 Shallow Loess Over Glacial Till

10 Loess Ridges And Sideslopes

11 Loess With Glacial Till Outcrops

12 Deep Loess

13 Missouri River Bluffs

14 Missouri River Alluvium

15 Loess Ridges/Glacial Till (Southwest lowa)

16 Loess, Shale, and Glacial Till
17 Loess Ridges/Glacial Till (Southeast lowa)

18 Eolian Sand

19 Loess (Timbered)

20 Alluvium

21 Loess Ridges/Glacial Till Sideslopes

22 Loess Ridges/Clay Paleosol

23 Water

Low-flow region boundary

Figure 2. Soil regions in lowa. 
closer to the surface and more bedrock outcropping than does the Southern Iowa Drift Plain. Topography of the region consists of steeply rolling hills and valleys. A mantle of loess covers the uplands and upper hill slopes. Soils in this region are characterized as loess over glacial till or limestone bedrock (Oschwald and others, 1965).

The Paleozoic Plateau landform region has a bedrockdominated, erosional topography that is characterized by plateau-like uplands, integrated drainage networks with steep gradients, and deeply entrenched valleys (Prior, 1991; Horick and Soenksen, 1989; Iowa Natural Resources Council, 1958). Stream erosion and hillslope development have stripped away glacial deposits from all but limited areas of this region. Karst topography occurs in the Paleozoic Plateau where carbonate rocks occur at depths of less than $50 \mathrm{ft}$ beneath the land surface. Dissolution of these carbonate rocks (limestone and dolomite) by groundwater has enlarged cracks and crevices in the bedrock and has resulted in surface depressions, sinkholes,

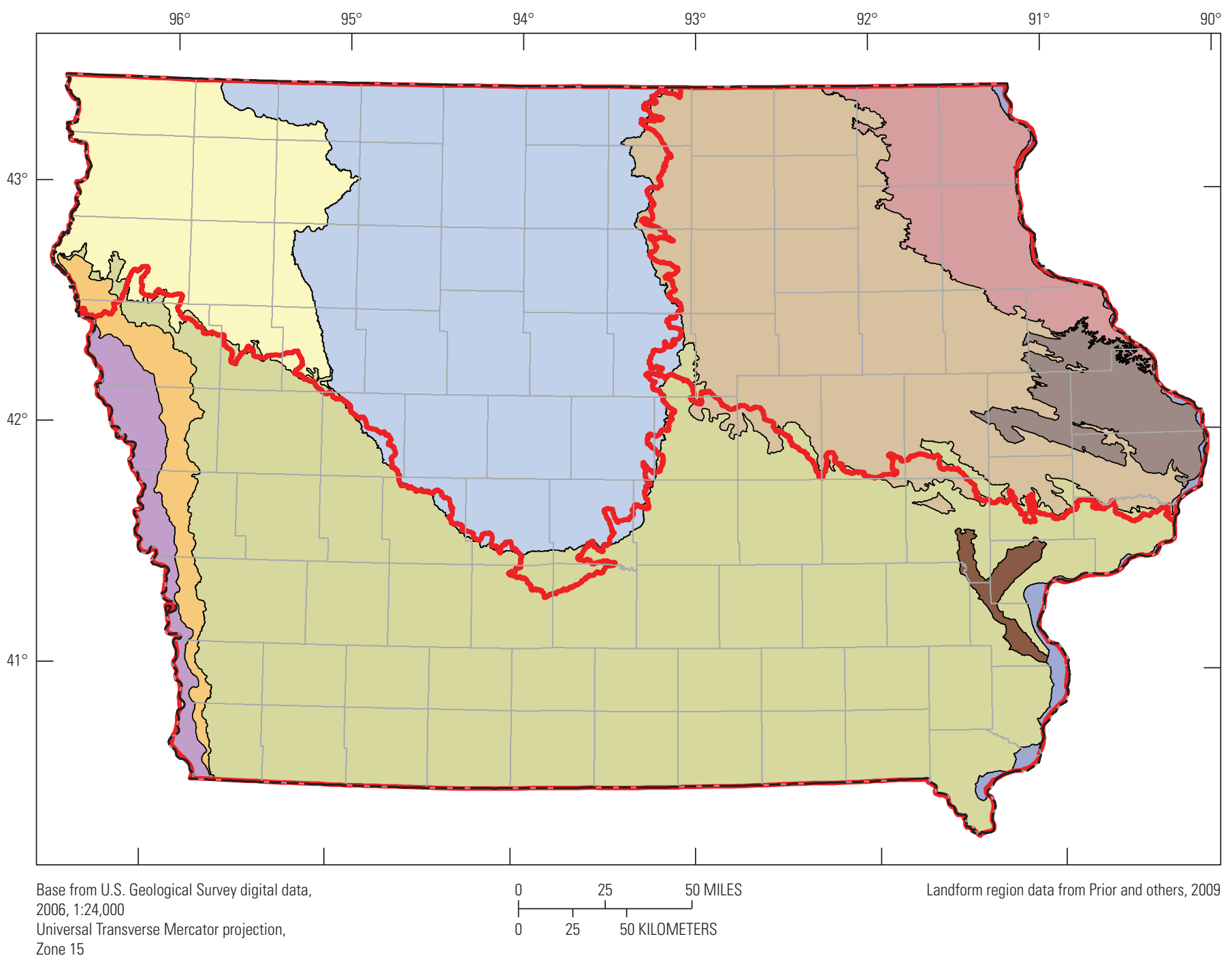

EXPLANATION

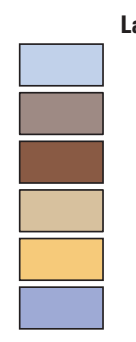

Landform region

Des Moines Lobe

East-Central lowa Drift Plain

lowa-Cedar Lowland

lowan Surface

Loess Hills

Mississippi River Alluvial Plain

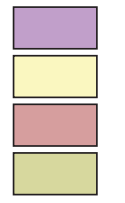

Missouri River Alluvial Plain

Northwest lowa Plains

Paleozoic Plateau

Southern lowa Drift Plain

Low-flow region boundary

Figure 3. Landform regions in lowa. 
caves, caverns, and springs. Where sinkholes have formed in streambeds, streams can abruptly disappear as surface-water runoff is captured and redirected to groundwater flow. Soils in this region are characterized as thin loess and glacial drift over bedrock or clay loam till (Prior, 1991; Oschwald and others, 1965).

The Loess Hills landform region is one of the State's most distinctive landscapes. The irregular Loess Hills extend as a narrow band that borders the full length of the Missouri River in western Iowa. The topography is sharp-featured, with alternating peaks and saddles that drop and climb along narrow, uneven ridge crests (Prior, 1991). A dense drainage network forming tight hollows, narrow ravines, and steep gullies distinguishes the intricately sculptured terrain. Loess is wind-deposited silt that is highly erodible and is very unstable when exposed surfaces become saturated with water. Loess depths in the Loess Hills are generally over $60 \mathrm{ft}$ (Prior, 1991).

Most precipitation in the study area results from storms moving inland primarily from the Gulf of Mexico and secondarily from the Pacific Ocean (Soenksen and Eash, 1991). Annual precipitation, which is mostly rain, ranges from 26 inches (in.) in the extreme northwest to as much as $38 \mathrm{in.} \mathrm{in}$ the southeast; the statewide average is around 34 in. (National Climatic Data Center, 2012). About 75 percent of the annual precipitation is received during April through September. Typically during August through February, streamflow in most unregulated streams in the study area is base flow; during March through July, streamflow is significantly greater, primarily as a result of snowmelt during late February through early April and rainfall during May through July. Annual minimum streamflows typically occur during August through February.

Base flow in streams in Iowa has increased, and more precipitation flowed into streams as base flow than as surface flow over the second half of the $20^{\text {th }}$ century (Schilling and Libra, 2003). Reasons for the observed base-flow trends are hypothesized to be as follows: improved conservation practices, added artificial drainage, increasing row crop intensity, and channel incision. Increasing base flow in streams in Iowa is significantly related to increasing row crop production; a 13- to 52-percent increase in row crop percentage in many Iowa basins has contributed to a 7- to 31-percent increase in base flow (Schilling, 2005). Analyses of streamflow trends for the United States found positive trends in minimum flows; the trends appear to have occurred around 1970 as an abrupt change rather than as a gradual change (McCabe and Wolock, 2002; Lins, 2005). Kendall's tau trend analysis of annual minimum daily mean discharges for 18 streamgages in Iowa included in the McCabe and Wolock (2002) study indicated significant positive trends for all 18 streamgages (David Wolock, U.S. Geological Survey, written commun., 2007). Lins (2005) found positive trends in the Upper Mississippi region and the pattern of trends is dominated by increases in streamflow during the months of September to December. A study by Small and others (2006) found that positive trends in 7-day low flow for the upper Mississippi region during 1948-97 appear to be related to an increase in fall precipitation.

\section{Previous Studies}

This is the fourth in a series of reports that describe low-flow characteristics for Iowa streams. The first report (Schwob, 1958) contained information on low-flow frequency and flow duration for 51 continuous-record streamgages using streamflow data collected through the 1953 water year and storage requirements for critical low-flow periods for 18 of the streamgages. A water year is the period October 1 through September 30 and is designated by the year in which it ends. Schwob also presented methods for estimating low-flow frequency and flow duration for ungaged sites that required the collection of discharge measurements at the ungaged sites. The second report (Heinitz, 1970) contained information on average discharge, low-flow frequency, flow duration, and storage requirements for continuous-record streamgages using streamflow data collected through the 1966 water year. Data on flow duration were presented for 113 streamgages and on low-flow frequency for 77 streamgages. Storage requirements for draft rates, or the amount of water that can be stored during high flows and released to supplement low flows, were presented for 65 streamgages. Annual 7-day mean low flows for a recurrence interval of 2 years (M7D2Y) were presented for 431 low-flow partial-record sites, and for some of these sites, M7D10Y low-flow frequency data were presented. Heinitz also presented a regression equation for estimating average discharge for ungaged sites that required the measurement of drainage area and annual precipitation for the ungaged site, and a method for estimating draft storage requirements for ungaged sites that required the collection of a few low-flow discharge measurements at ungaged sites. The third report (Lara, 1979) contained information on annual and seasonal low-flow frequency and flow duration for 142 continuousrecord streamgages using streamflow data collected through the 1976 water year. Data on the average discharge, the 84-percent exceedance discharge, and the M7D2Y and M7D10Y low-flow frequency discharges were presented for 426 low-flow partial-record sites. Lara (1979) also presented a regional regression equation for estimating average discharge for ungaged sites for three hydrologic regions identified for the State that required the measurement of drainage area and annual precipitation. Lara (1979) attempted to develop regional regression equations for low-flow frequency, but reported the equations could not be successfully applied because low flows are closely related to geologic characteristics, which at the time, could not be easily quantified or described by simple indexes. The collection of base-flow discharge measurements at ungaged sites remained the recommended procedure for estimating low-flow characteristics. Two maps (plates 3 and 4) show areal trends of M7D2Y and M7D10Y low-flow frequency discharges that could be used for very approximate estimates (Lara, 1979). 


\section{Methods for Data-Set Development for Streamgages}

Data used in this report were collected for 208 active and inactive continuous-record streamgages located in Iowa and within a 50-mi buffer of Iowa in the neighboring States of Illinois, Minnesota, Missouri, Nebraska, South Dakota, and Wisconsin (fig. 1 and table 1 at end of report). Streamgages with at least 10 complete years of daily mean discharges and unaffected by regulation or diversion were initially selected for evaluation in the study, which included 133 streamgages in Iowa and 75 streamgages in neighboring States. Streamgages from neighboring States were used to improve the representativeness of selected low-flow frequency statistics and harmonic mean flows and basin characteristics found in Iowa border areas and to provide better estimates of the error of the regression equations for ungaged sites near the State border. Daily mean discharge data collected through the 2006 water year (through September 30, 2006) were retrieved for the 208 streamgages from the USGS National Water Information System (NWIS) database for use in computing selected lowflow frequency statistics and harmonic mean flows.

Streamflow data were reviewed to eliminate data affected by regulations or diversions from biasing the computation of selected low-flow frequency statistics and harmonic mean flows. Decisions on inclusion or exclusion of data for streamgages were made using hydrologic judgment according to available information regarding the occurrence, timing, and extent of regulations or diversions upstream from the streamgages. No explicit decision criteria were used. In general, all streamgages with data affected by upstream regulations or affected by upstream diversions during typical low-flow periods were deleted from the study data set. Information available about possible regulations or diversions at streamgages was not always complete and the veracity was questionable in some cases. Thus, it is possible that some data affected by regulation or diversion could have been included in the study data set. However, the overall effect on the development of regional regression equations is believed to be minimal. Streamflow statistics for 22 streamgages operated by the Iowa Water Science Center that were excluded from this study are presented in the appendix.

A standard, continuous-record streamgage records gage height (the stage or water-surface elevation) continuously from which a daily mean discharge is computed by use of a stage-discharge relation. A low-flow partial-record site is a site on a stream where base-flow discharge measurements are collected periodically for correlation to streamflows at a nearby hydrologically similar streamgage. As noted in the previous section, 426 low-flow partial-record sites located in Iowa were included in the last low-flow study (Lara, 1979). Base-flow measurements were collected at these sites during 1957 to 1976, since then, no additional measurements have been collected. Low-flow studies typically include data from partial-record sites to supplement the continuous-record streamgage data set with an expanded range and geographic coverage of basin and low-flow characteristics. On the basis of studies indicating positive trends in low flows in Iowa and the Upper Mississippi region (Schilling and Libra, 2003; Schilling, 2005; McCabe and Wolock, 2002; Lins, 2005) and on the basis of computations of M7D10Y low-flow frequency statistics for several Iowa streamgages included in this study that also indicated positive trends in annual low flow for different record lengths, data from the 426 partial-record sites were not included in this study because of the possibility that data limited to the period 1957-76 may bias the results of regional regression equations.

\section{Low-Flow Frequency}

To estimate low-flow discharges for selected recurrence intervals at continuous-record streamgages, such as the M7D10Y, a low-flow frequency analysis was performed. For this report, low-flow frequencies were estimated for annual statistics of M1D10Y, M7D10Y, M30D10Y, and M30D5Y and for seasonal statistics (October 1 through December 31) of M1D10Y1012 and M7D10Y1012 for each of the 208 streamgages (table 1). The magnitude and frequency of low flows are computed for a streamgage by relating a specific number of consecutive daily mean discharges during an annual period to annual minimum nonexceedance probability or recurrence interval. Annual nonexceedance probability is expressed as the chance that a selected low-flow magnitude will not be exceeded in any one year. Recurrence interval, which is the reciprocal of the annual nonexceedance probability, is the average number of years between nonexceedances of a selected low-flow magnitude. For example, if a theoretical 7-day mean low-flow discharge is not exceeded once on the average during any 10-year period (recurrence interval), then it has a 10-percent chance (annual nonexceedance probability equals 0.1 ) of not being exceeded during any one year. This low-flow discharge is referred to as the annual 7-day, mean low flow for a recurrence interval of 10 years, or M7D10Y. Likewise, if a theoretical 30-day mean low-flow discharge is not exceeded on the average during any 5 -year period, then it has a 20-percent chance of not being exceeded during a specific year. This low-flow discharge is referred to as the annual 30-day, mean low flow for a recurrence interval of 5 years, or M30D5Y. Although the recurrence interval represents the long-term average period between low flows of a specific magnitude, rare low flows could occur at shorter intervals or even within the same year. Discharge values estimated for low-flow frequency statistics like M7D10Y and M30D5Y change as streamflow records become longer.

The USGS has established standard methods for estimating low-flow frequency statistics for streamgages (Riggs, 1972). In this study, the USGS computer programs IOWDM, ANNIE, and SWSTAT (http://water.usgs.gov/software/ surface_water.html) were used to format daily mean discharge data and to compute N-day, Kendall's tau, flow duration, and 
low-flow frequency analyses (Lumb and others, 1990; Flynn and others, 1995).

\section{N-Day Analyses}

Low-flow frequency statistics are computed using the annual minimum mean discharges for any specific number of consecutive days (N-day low flows) during an annual period. The mean discharge for each $\mathrm{N}$-day period throughout the annual period is calculated and the minimum value is used for that annual period. For example, the M7D10Y low-flow statistic is computed from the annual series of minimum 7-day mean flows for a streamgage. From the daily mean discharge record, the mean flow for each consecutive 7-day period is determined and the lowest mean value for each year is assigned to that year in the annual series. The series of annual minimum $\mathrm{N}$-day values are then fit to a log-Pearson Type III distribution to determine the low-flow frequency (Riggs, 1972). More specific information about the log-Pearson Type III distribution can be found in Interagency Advisory Committee on Water Data (1982). Low-flow frequency statistics also can be computed on a seasonal or monthly basis by limiting the daily mean discharge data used for the annual series to just the season or month of interest. For example, M7D10Y1012 low-flow statistics for the fall season are computed by fitting a probability distribution to the annual series of minimum 7-day mean flows calculated from daily mean discharges during October 1 through December 31 of each year. Annual and seasonal N-day discharge values for some streamgages included this study were equal to zero. A conditional probability adjustment for zero flow values (Interagency Advisory Committee on Water Data, 1982, appendix 5) was used for low-flow frequency analyses for streamgages with one or more annual or seasonal $\mathrm{N}$-day discharge values of zero.

The annual period used in this study for the computation of annual low-flow frequency statistics is defined as the climatic year (April 1 through March 31). The climatic year is used for low-flow frequency analyses because low-flow events in Iowa typically occur during the late summer through winter months. N-day periods analyzed in this study for each annual climatic year were 1-, 7-, and 30-day periods. A seasonal period (October 1 through December 31) also was used in this study for the computation of fall low-flow frequency statistics. N-day periods analyzed in this study for each annual fall season were 1- and 7-day periods. For streamgages included in the study, the number of climatic years of record are often one year less than the number of fall (October 1 through December 31) years of record (table 1) because many streamgages are operated on a water-year basis (October 1 to September 30), and the first half of the first water year of record is not included when analyzing the data by climate year because of incomplete data for a full climate year. As a result, seven streamgages with at least 10 years of fall record only had 9 years of annual climate-year record (table 1); five of these seven streamgages were included in the study for the development of regression equations for low-flow frequency statistics for the fall season and for the harmonic mean flow, but were not included in the study for the development of annual (climate-year) regression equations for low-flow frequency statistics.

\section{Trend Analyses}

$\mathrm{N}$-day data calculated for annual climatic years and for annual fall seasons were analyzed for the entire period of record (table 1) for trends using the Kendall's tau hypothesis test in the SWSTAT program (Lumb and others, 1990). Trends in the N-day data could introduce a bias into the low-flow frequency analyses because a major assumption of frequency analyses is annual low flows are independent and stationary over time. The Kendall's tau test computes the monotonic relation between $\mathrm{N}$-day values (discharge) and time (climatic years) (Helsel and Hirsch, 2002). A p-value threshold of 5 percent $(\alpha=0.05)$ was used in this study for the Kendall's tau test and $p$-values less than or equal to 5 percent were flagged as having statistically significant trends (positive or negative). Five Kendall tau tests, one test for each annual and fall $\mathrm{N}$-day record, were performed for each streamgage included in the study. The Kendall's tau test was performed for the five $\mathrm{N}$-day time series at each streamgage: the annual climate-year minimum 1-, 7-, and 30-day low flows and the annual fall minimum 1- and 7-day low flows. Results of the Kendall's tau tests indicated statistically significant positive trends for 133 of the 208 streamgages tested using the entire period of record. Annual and seasonal precipitation data for Iowa were tested for trends using Kendall's tau analyses. While statistically significant trends in Iowa precipitation are apparent for some areas of the State for some of the periods of record tested, the precipitation data do not appear to fully explain the low-flow trends. Changes in agricultural practices are hypothesized to be the primary cause of the positive low-flow trends in the State (Schilling and Libra, 2003: Schilling, 2005). Two approaches were considered for this study to try to minimize the bias of significant positive trends in the computation of selected low-flow frequency statistics and harmonic mean flows: (1) use a common period of record for each streamgage (for example, do not use any N-day values prior to 1970) or (2) use a variable length of record for each streamgage (use the longest, most recent period of record without a significant trend). Because the variable-length record approach allows for longer record lengths to be included for many streamgages, it was selected for use in this study. A series of Kendall's tau analyses were computed for each streamgage using the initial base period 1985-2006; from 1985, the length of record tested was increased by 5 -year increments backwards in time until a significant positive trend was detected for any one of the five $\mathrm{N}$-day annual low-flow records being tested. Trend analyses were then computed by decreasing the length of record by 1-year increments sequentially until a significant positive trend was not detected for each of the five $\mathrm{N}$-day records. This procedure was used for each streamgage to determine the beginning year of the longest period of recent record without 
a significant trend for any of the five N-day records. Approximately 10,000 Kendall's tau trend analyses were computed as part of the variable-length record approach. Results of the trend analyses indicated a strong directional effect in which streamgages in the eastern and southern areas of the State have longer periods of record without significant trends compared to streamgages in the western and northern parts of the State. Streamgages with discontinued or intermittent records were evaluated with respect to other nearby streamgage records to determine an appropriate period of record to use. Table 1 lists the longest period of record without a significant trend for all five N-day records for each streamgage under the column heading of "Period of record used for low-flow study." A difference in the period of record listed in this column from the preceding column heading of "Entire period of record," indicates that a significant trend was found for the entire period of record and a shorter period of record was used for the computation of selected low-flow frequency statistics and harmonic mean flows.

The number of climatic years used for the low-flow study for the 208 streamgages ranged from 10 to 70 years with a mean of 33.3 years and a median of 35 years. The number of years of fall record used in the study ranged from 10 to 72 years with a mean of 33.0 years and a median of 35 years.

\section{Harmonic Mean Flow}

Design flows are used in water-pollution control programs to provide adequate protection against pollutant exposure periods of a given duration (Rossman, 1990a). The harmonic-mean-flow statistic (QAH) can serve as a design flow for human health criteria that are based on lifetime exposures because it can be used to calculate the average exposure concentration of a contaminant for an average contaminant loading rate (Rossman 1990b; Koltun and Whitehead, 2002). A QAH value was calculated for each of the 208 streamgages from the daily mean discharge record using the USGS BIOFLO (version 2.0) computer program (Straub, 2001), which is based on a computer program developed by the U.S. Environmental Protection Agency called DFLOW (Rossman, 1990b). The exposure concentration will be greater and more deleterious on days with low flow than on days with high flows. The QAH statistic computed from a streamflow record generally is smaller than the corresponding arithmetic mean discharge, is adjusted for the days with zero flow, and gives greater weight to low daily mean discharges than high daily mean discharges. The QAH streamflow statistic is calculated as:

where

$$
Q A H=\left(\frac{N_{n z}}{N_{t}}\right)\left(\frac{N_{n z}}{\sum_{i=1}^{N_{n z}} \frac{1}{Q_{i}}}\right)
$$

$Q_{i} \quad$ is the daily mean discharge,

$N_{n z} \quad$ is the number of non-zero $Q_{i}$, and

$N_{t} \quad$ is the total number of $Q_{i}$.
If $N_{n z}$ equals $N_{t}$, QAH is equal to the reciprocal of the mean of the reciprocals of all $Q_{i}$. Values of QAH computed for each of the 208 streamgages are presented in table 2 (at end of report) as observed values.

\section{Streamflow-Variability Index}

The streamflow-variability index (STREAM_VAR) initially was proposed by Lane and Lei (1950) to help produce synthetic flow-duration curves. Subsequently, a generalized STREAM_VAR has been used in the development of regression equations for estimating QAH in Kentucky (Martin and Ruhl, 1993) and Ohio (Koltun and Whitehead, 2002), and for estimating low-flow frequency statistics in Kentucky (Martin and Arihood, 2010).

A STREAM_VAR value was calculated for each of the 208 streamgages (observed value listed in table 3 at end of report) by (1) computing a flow-duration curve using daily mean discharge data to obtain discharge values at 5-percent exceedance intervals from 5 to 95 percent, and (2) calculating the standard deviation of the logarithms of the 19 discharge values corresponding to the 5-percent exceedance intervals from 5 to 95 percent (Searcy, 1959). The flow-duration curve is a cumulative frequency curve that shows the percentage of time that a specific discharge is equaled or exceeded (fig. 4). For example, the 80th percentile represents the discharge value that 80 percent of the daily mean discharges are equal to or greater than.

The STREAM_VAR statistic is calculated as:

$$
\text { STREAM_VAR }=\sqrt{\frac{\sum_{i=5,5}^{95}\left(\log \left(Q_{c i}\right)-\overline{\log \left(Q_{c}\right)}\right)^{2}}{18}}
$$

where

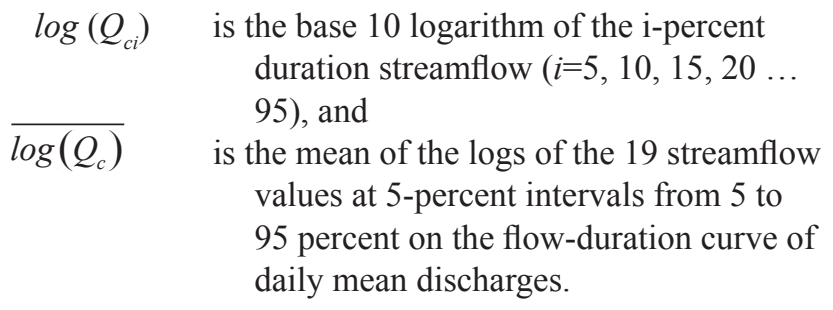

If an i-percent duration streamflow value is zero (which cannot be $\log$-transformed), the $\log \left(Q_{c i}\right)$ value was set to zero in equation 2 to allow all nineteen 5-percent intervals to be included in the calculation of STREAM_VAR.

STREAM_VAR is a measure of the slope of the flowduration curve and is a measure of the capacity of a watershed to sustain base flow in a stream (Martin and Arihood, 2010). Small values of STREAM_VAR (less than about 0.55 ) indicate a flatter slope of the flow-duration curve and represent sustained base flows. Large values of STREAM_VAR (greater than about 0.55 ) indicate a steeper slope of the flow-duration curve, which may go to zero flow at the low end (high percentiles); such large values represent an absence of sustained 


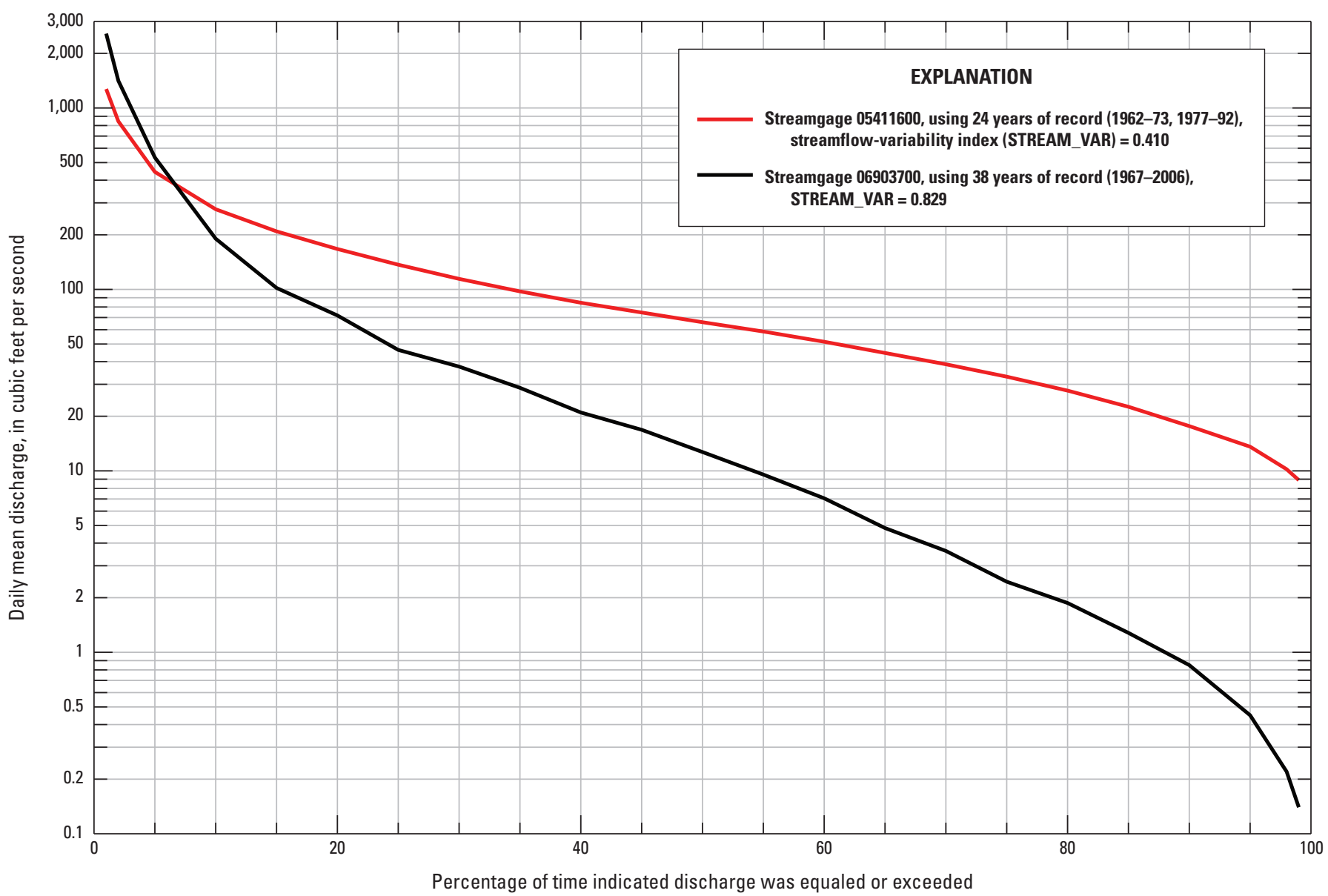

Figure 4. Examples of flow-duration curves for streamgages Turkey River at Spillville, lowa (streamgage 05411600, map number 15), and South Fork Chariton River near Promise City, lowa (streamgage 06903700, map number 207).

base flow. Flow-duration curves for which relatively small and large STREAM_VAR values were computed are shown in figure 4 for two streamgages in Iowa. The Turkey River at Spillville, Iowa (streamgage 05411600, map number 15), has a published drainage area of $177 \mathrm{mi}^{2}$ and an observed STREAM_VAR value of 0.410 calculated from 24 years of record. The South Fork Chariton River near Promise City, Iowa (streamgage 06903700, map number 207), has a similar published drainage area of $168 \mathrm{mi}^{2}$ and an observed STREAM_VAR value of 0.829 calculated from 38 years of record. The duration curve for the Turkey River streamgage is much flatter than the curve for the Chariton River streamgage, which indicates sustained base flow at the Turkey River streamgage; whereas the steeper duration curve for the Chariton River streamgage indicates the absence of sustained base flows.

\section{Base-Flow-Recession Time Constant}

Boussinesq (1903) advanced the refined problem of outflow from a horizontal, unconfined aquifer discharging into a fully incised stream (Funkhouser and others, 2008). Brutsaert and Nieber (1977) demonstrated that the Boussinesq problem can be calculated as:

$$
\frac{d Q}{d t}=-a Q^{b}
$$

where

$$
\begin{array}{ll}
Q & \text { is streamflow, } \\
T & \text { is time, and }
\end{array}
$$

$a$ and $b \quad$ are constants.

For this low-flow study, only the large-time behavior was analyzed (Funkhouser and others, 2008), for which a value of 1 generally is assigned to $b$ (Brutsaert and Lopez, 1998; Eng and Brutsaert, 1999). For the large-time solution, $a$ is calculated as:

$$
\alpha=\frac{1}{\tau}=\frac{\pi^{2} K p d L_{s}^{2}}{f A^{2}}
$$

where

$\tau \quad$ is the reciprocal of $a$ (see equation 3 ),

$K \quad$ is the hydraulic conductivity, 
$p \quad$ is approximately 0.3465 (Brutsaert and

Nieber, 1977),

$d \quad$ is the aquifer thickness,

$L_{\mathrm{s}} \quad$ is the upstream stream length,

$f$ is the drainable porosity, and

$A \quad$ is the drainage area;

and thus:

$$
Q_{t+\Delta t}=Q_{t} e^{-\Delta t / \tau}
$$

where

$$
\begin{aligned}
\mathrm{Q}_{t+\Delta t} & \text { is the streamflow at time } t+\Delta t \\
Q_{t} & \text { is the streamflow at time } t, \text { and } \\
\Delta t & \text { is the change in time. }
\end{aligned}
$$

The variable $\tau$ is a long-term base-flow-recession time constant, which characterizes the rate of recession of base flow as a number of days (Brutsaert and Lopez, 1998; Eng and Brutsaert, 1999); the variable $\tau$ will hereby be referred to as the streamflow statistic TAU_ANN. Instead of using equation 4, an effective value of TAU_ANN can be calculated from daily mean discharges for continuous-record streamgages by use of equation 5 (Eng and Milly, 2007; Funkhouser and others, 2008). An empirical Monte Carlo program (EmpMC program; Ken Eng, U.S. Geological Survey, written commun., 2007) was used to identify 500 pairs of days using a peak threshold of 25 percent. The 25-percent threshold is used to limit the program analysis to hydrograph peaks below the 25 th percentile duration value of the record of daily mean discharges. The program was used to compute TAU_ANN and TAU_1012 (October 1 through December 31) values for each of the 208 streamgages for six different 4-day periods. Covariances computed for the six different analyses were used to determine the best 4-day period to use for computing TAU_ANN and TAU_1012 values for this study. The time period of 6-9 days following the start of a hydrograph recession was selected as the best 4-day period to use for Iowa. The associated daily mean discharges for these days then were used to compute 500 TAU_ANN values for each of the 208 streamgages using equation 5. Observed TAU_ANN baseflow-recession time constant values, computed as the mean of the 500 values, are listed in table 3 for each streamgage.

\section{Base Flow}

Two base-flow separation programs, base-flow index and hydrograph separation and analysis, were used in this study to compute the base-flow component of streamflow. Both programs partition the streamflow hydrograph into surface-runoff and base-flow components. The surface-runoff component is associated with precipitation that enters the stream as overland runoff and the base-flow component with groundwater discharge.

\section{Base-Flow Index}

A computer program called Base-Flow Index (BFI) (Wahl and Wahl, 1988, 1995) implements a technique developed by the Institute of Hydrology (1980a, 1980b) that divides the water year into $\mathrm{N}$-day increments and the minimum streamflow is determined during each $\mathrm{N}$-day period. Minimum $\mathrm{N}$-day streamflows are compared to adjacent $\mathrm{N}$-day minimums to identify turning points on a base-flow hydrograph (Esralew and Lewis, 2010). Straight lines between the turning points designate the base-flow hydrograph, and an estimate of the volume of base flow is calculated from the area beneath the hydrograph. The BFI program computes a ratio of base flow to total streamflow for each year of record, and the mean value of the annual ratios is used for the BFI value. A BFI value was computed for each of the 208 streamgages (observed value listed in table 3).

The default N-day period used by the BFI program is 5 days. This $\mathrm{N}$-day period is not appropriate for all streamgages. To identify an appropriate $\mathrm{N}$ value for each streamgage, $\mathrm{BFI}$ values were calculated for $\mathrm{N}$ values ranging from 1 to 10 days. A graph showing the relation of $\mathrm{N}$ values and BFI was used to determine an appropriate $\mathrm{N}$ value for each streamgage through a visual identification of a change in slope of the graph. An appropriate $\mathrm{N}$ value to use for BFI was selected from the graph where the slope no longer substantially changed (Wahl and Wahl, 1995). Figure 5 shows the graph for the Chariton River near Chariton, Iowa (streamgage 06903400, map number 205) for which an $\mathrm{N}$ value of 2 was selected from the graph and thus a BFI value of 0.182 was determined for the period of record analyzed. The default value of 0.9 for the turning point parameter $(f)$ was used for all

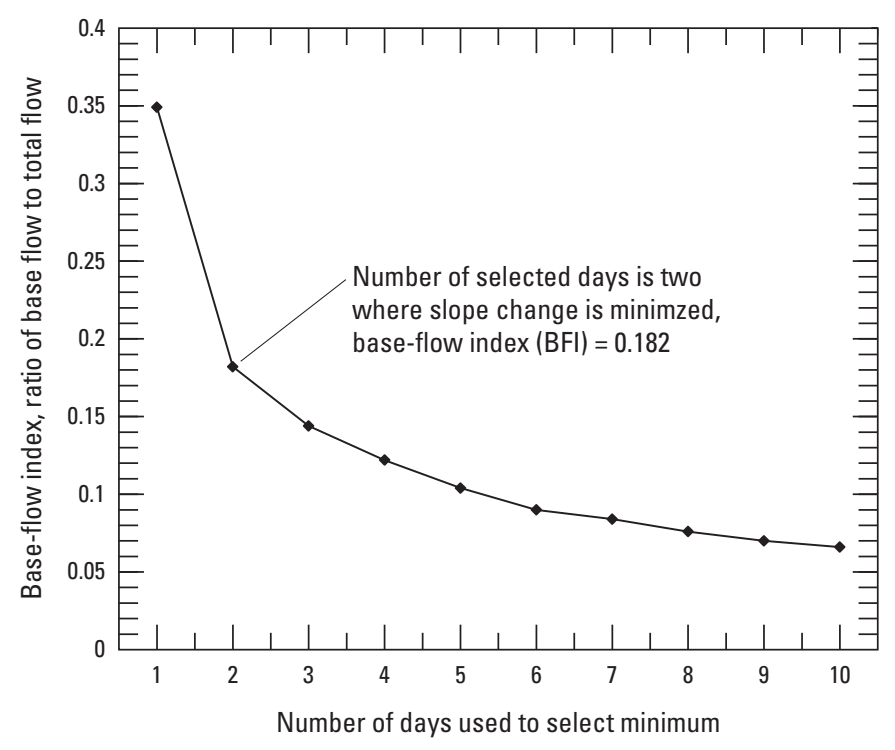

Figure 5. Relation between base-flow index (BFI) and number of days (N) used to select an appropriate $\mathrm{N}$ value for $\mathrm{BFI}$ for the streamgage Chariton River near Chariton, lowa (streamgage 06903400, map number 205). 
streamgages because BFI computations have not been shown to be highly sensitive to variations of $f$ (Wahl and Wahl, 1995).

\section{Hydrograph Separation and Analysis of Base Flow}

A computer program for streamflow hydrograph separation and analysis called HYSEP (Sloto and Crouse, 1996) implements three techniques developed by Pettyjohn and Henning (1979). The local minimum technique was used in this study. This method checks each daily mean discharge value for a specified period of record to determine if a particular day has the lowest discharge in one-half the interval minus 1 day before and after that day. If a particular day is the lowest discharge, then it is a local minimum and a straight line is used to connect that particular day to adjacent local minimums. Linear interpolations are used to estimate base-flow values for each day between local minimums. The local minimum technique can be visualized as connecting the lowest points on the hydrograph with straight lines. The HYSEP program computes a percentage of base flow to total streamflow for each year of record, and the median value of the annual percentages is used for the HYSEP value. A HYSEP value was computed for each of the 208 streamgages (observed value listed in table 3).

Table 4 summarizes mean and median BFI and HYSEP values for all streamgages located in Iowa (excludes the 75 streamgages in adjacent States) and for each of the three low-flow regions. Seven streamgages located in Iowa, which are not assigned to low-flow regions in table 1, were included in the statewide summary but not included in the regional summaries. Mean and median summary values listed in table 4 for BFI and HYSEP indicate that the northeast region has the greatest percentage (58 to 59 percent) of base flow to annual streamflow compared to the rest of the State, and that the southern region has the smallest percentage ( 46 to 51 percent) of base flow to annual streamflow. Mean and median summary values for the northwest region are slightly smaller than those for the northeast region indicating that the percentage of base flow to annual streamflow is about 5 to 13 percent greater for the northern regions compared to the southern region.

\section{Basin Characteristics}

Low-flow characteristics of streams are related to the physical, geologic, and climatic properties of drainage basins (Smakhtin, 2001). In most studies, drainage area is a significant variable in explaining low-flow variability (Funkhouser and others, 2008; Kroll and others, 2004). Basin characteristics investigated in this study as potential explanatory variables in the regression analysis were selected on the basis of their theoretical relation to low flows, results of previous studies in similar hydrologic areas, and the ability to quantify the basin characteristics using GIS technology and digital data sets. The use of GIS enables the automation of the basin-characteristic measurements and solution of the regional regression equations using StreamStats.

Using GIS technology, 54 basin characteristics were measured for each of the 208 streamgages include in this study. Table 5 (at end of report) provides a brief description of each basin characteristic and the data source used to measure the characteristic. Basin-characteristic names used in this study were selected to maintain consistency with the names of explanatory variables in the USGS StreamStats Web-based GIS tool (http://water.usgs.gov/osw/streamstats/bcdefinitions1. $h t m l)$.

The basin characteristics can be separated into four categories: morphometric (physical or shape) characteristics, hydrologic characteristics, pedologic (soils)/geologic/land use characteristics, or climatic characteristics. Morphometric characteristics were measured from one to three data sources, which are described in the following section Geographic Information System Measurements. Hydrologic characteristics were initially computed for each streamgage using daily mean discharge data as previously described in the sections Streamflow-Variability Index, Base-Flow-Recession Time Constant, and Base Flow and were subsequently mapped using a kriging procedure that is described in the following section Kriged Hydrologic Characteristics. The pedologic, geologic, and land-use characteristics were computed from the NRCS Soil Survey Geographic (SSURGO) Database (Soil Survey Staff, 2012) for the seven soil characteristics, from the Iowa Geological and Water Survey Des Moines Lobe landform region boundary for the Des Moines Lobe geologic

Table 4. Summary of base-flow index (BFI) and hydrograph separation and analysis (HYSEP) of base-flow values computed from observed streamflow for streamgages in lowa.

\begin{tabular}{lccccc}
\hline \multicolumn{1}{c}{ Region } & $\begin{array}{c}\text { Number of } \\
\text { streamgages }^{\mathbf{1}}\end{array}$ & $\begin{array}{c}\text { Mean BFI } \\
\text { (percent) }\end{array}$ & $\begin{array}{c}\text { Median BFI } \\
\text { (percent) }\end{array}$ & $\begin{array}{c}\text { Mean HYSEP } \\
\text { (percent) }\end{array}$ & $\begin{array}{c}\text { Median HYSEP } \\
\text { (percent) }\end{array}$ \\
\hline Statewide & 2133 & 52 & 55 & 52 & 55 \\
Northeast & 32 & 59 & 58 & 59 & 58 \\
Northwest & 31 & 56 & 56 & 56 & 56 \\
Southern & 63 & 46 & 50 & 46 & 51 \\
\hline
\end{tabular}

${ }^{1}$ Excludes 75 streamgages located in adjacent States.

${ }^{2}$ Includes seven streamgages in Iowa listed in table 1 that are not assigned to low-flow regions. 
characteristic (Prior and others, 2009), and from the MultiResolution Land Characteristics Consortium 2001 National Land Cover Database for the land-use characteristic that measured percent area of row crops (http://www.mrlc.gov/ index.php; Homer and others, 2004). The climatic characteristics were computed from Oregon State University Parameterelevation Regressions on Independent Slopes Model (PRISM) data sets (PRISM Climate Group, 2008).

\section{Kriged Hydrologic Characteristics}

Kriging is a geostatistical method that can be used to determine optimal weights for measurements at sampled locations (streamgages) for the estimation of values at unsampled locations (ungaged sites). Values initially computed for the five hydrologic characteristics (BFI, HYSEP, TAU_ANN, TAU_1012, and STREAM_VAR; table 3 does not include TAU_1012) from daily mean discharge data were subsequently kriged to create isoline maps using Geostatistical Analyst tools in ArcGIS version 9.3 (Environmental Systems Research Institute, 2001, 2009). These five kriged grids then were used to interpolate values for each of five hydrologic characteristics for each of the 208 streamgages for use as explanatory variables in the regression analyses. Prior to kriging, semivariogram modeling was used to characterize the degree of spatial correlation in each of the hydrologiccharacteristic data sets using Geostatistical Analyst tools in ArcGIS version 9.3 (Environmental Systems Research Institute, 2001, 2009). The semivariogram model defines the linear weighting function used to krige each grid of observed hydrologic-characteristic values. An informative discussion of semivariogram modeling and kriging is presented in Bossong and others (1999) and in Environmental Systems Research Institute (2001).

Each hydrologic-characteristic data set was checked for anisotropy, which indicates a directional trend in the spatial correlation of the data. Four of the five hydrologic-characteristic data sets (BFI, HYSEP, TAU_ANN, and TAU_1012) were determined to be anisotropic, and directional semivariogram modeling was used to account for the directional trends. The STREAM_VAR data set was determined to be isotropic, and directional semivariogram modeling was not required. Figure 6 shows the semivariogram model that was developed for the STREAM_VAR data plotted with a lag of 25,000 meters $(\mathrm{m})(15.5 \mathrm{mi})$. The semivariogram shows a plot of the squared differences per pair of STREAM_VAR values as a function of distance between streamgages. The correlation between STREAM_VAR values at two streamgages is assumed to depend on the distance between the two streamgages. This dependence can be evaluated by squaring the difference between the STREAM_VAR values at each pair of streamgages and then grouping the squared differences according to the distance between the paired locations. A model that is represented by a mathematical expression is fit to the semivariogram points to pass a smooth curve through the scattered points. A number of different semivariogram models were tested for best fit of each hydrologic-characteristic data set and cross-validation estimation accuracy. Various model parameters also were tested for each hydrologic-characteristic data set, including the number of lags, lag sizes, nugget values, partial sill values, major range values, minor range values, search angles, and the maximum and minimum number of streamgages to include in the searches. The semivariogram model for STREAM_VAR (fig. 6) was developed using 204 of the initial 208 streamgages. Four outliers were removed from the data set to improve the fit of the semivariogram model to the data and to improve the estimation accuracy of the model. Three to four outliers also were removed from each of the other four hydrologic-characteristic data sets to improve the fit and accuracy of the models. A Gaussian model was determined to provide the best fit and estimation accuracy for all five of the hydrologic-characteristic data sets. The Gaussian model parameters used to fit the STREAM_VAR semivariogram (fig. 6) are listed in table 6 with the Gaussian model parameters used to fit semivariograms for the other four hydrologic-characteristic data sets.

The parameters of preliminary semivariogram models were calibrated using a kriging cross-validation technique. In this technique, the fitted semivariogram is used in a series of sequential kriging analyses in which data points are individually deleted and estimates are made for the deleted point locations. After kriged values at all data point locations have been estimated, the kriged values and standard deviations of the data are used to obtain cross-validation prediction errors. A successful calibration is based on the criteria for these prediction errors. Generally, the best model has the standardized mean nearest to zero, the smallest root-mean-squared prediction error, the average standard error nearest to the root-mean-squared prediction error, and the standardized rootmean-squared prediction error nearest to one (Environmental Systems Research Institute, 2001). Cross-validation prediction errors are listed in table 7 for the semivariogram models used to krige the five hydrologic-characteristic data sets (table 6).

Universal or ordinary kriging was used to create a grid of estimated values for the study area for each of the five hydrologic characteristics. The grids created from the kriging process were contoured using ArcGIS version 9.3 (Environmental Systems Research Institute, 2009) to create isoline maps. Several different grid sizes were tested during the kriging and contouring process to evaluate the detail and generality of isoline delineations. Grid spacings of 47,000 m (29.2 mi) for STREAM_VAR and TAU_ANN, 50,000 m (31.1 mi) for TAU_1012, 64,000 m (39.8 mi) for HYSEP, and 67,000 m $(41.6 \mathrm{mi})$ for BFI were determined to provide the best balance between creating isoline maps with the lowest prediction errors and isoline delineations considered to provide the best level of detail and generality. Isoline maps created from kriged grids for three (STREAM_VAR, TAU_ANN, and BFI) of the five hydrologic characteristics that were used to develop regression equations are shown in figures 7-9. 


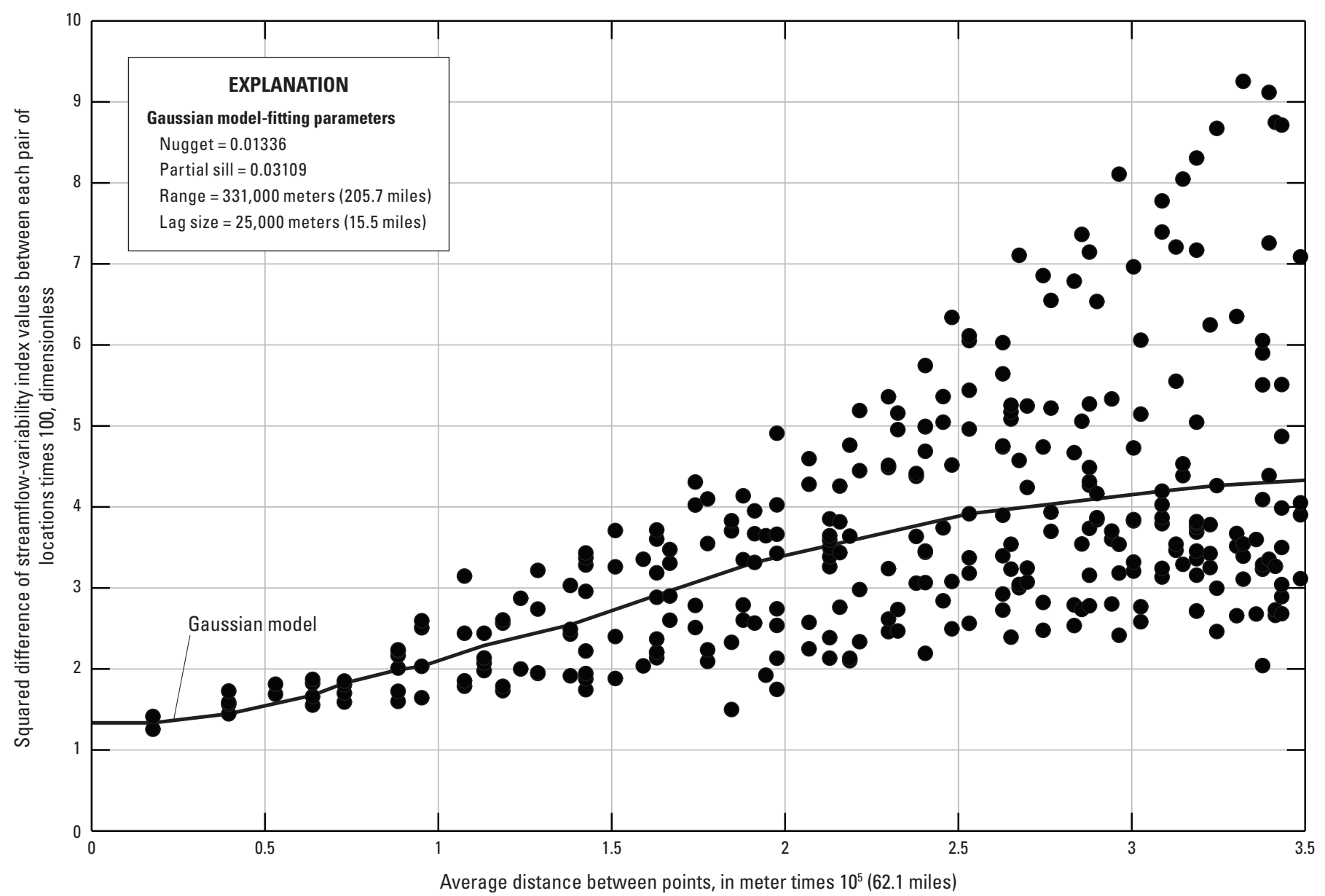

Figure 6. Semivariogram used to krige estimates of streamflow-variability index (STREAM_VAR) for lowa.

\section{Geographic Information System Measurements}

Three primary GIS-data layers were processed to produce the Iowa StreamStats data layers. These data layers were needed to delineate accurate stream networks and basin boundaries, and the layers were used to measure 27 morphometric basin characteristics (table 5). The three primary GIS-data layers include the 1:24,000-scale USGS National Hydrography Dataset (NHD) (http://nhd.usgs.gov/; Simley and Carswell, 2009), the 1:24,000-scale USDA/NRCS Watershed Boundary Dataset (WBD) (http://datagateway.nrcs.usda. gov/; USGS and NRCS, 2009) using 12-digit hydrologic unit codes (HUCs), and the 10-m (32.81 ft) USGS National Elevation Dataset (NED) (http://ned.usgs.gov/; Gesch, 2007).

Several preprocessing steps were needed for each of the three data layers to facilitate rapid determination of basin characteristics. Preprocessing of the NHD included removing flowline paths that represent man-made features (a stream network that only represents natural streams is needed) and selection of the primary flow path in those areas where the NHD indicated split flow (such as might occur when flow splits around an island in a river or with a braided channel). The NHD and WBD had to be verified that the stream from the NHD only crossed the watershed boundary (from the WBD) at the outlet (unless the watershed is downstream from another watershed, in which case the main-stem stream will enter the watershed at one place); and watershed outlets should align exactly to the confluences of the streams. For the NED, downloaded blocks were mosaicked into one tile, data were extracted for a 4-kilometer $(\mathrm{km})(2.5 \mathrm{mi})$ buffer area around each 8-digit HUC, and projected from decimal degrees to Universal Transverse Mercator (UTM) Zone 15. A hydrocorrected digital elevation model (DEM) was then developed by filling depressions or sinks, using the basin boundaries from the WBD to conserve known drainage divides, and using the streams from the NHD to create well-defined flow paths through the elevation data.

ArcHydro Tools, version 1.3, a set of utilities developed to operate in the ArcGIS, version 9.3, environment (Environmental Systems Research Institute, 2009) was used to process fifty-eight 8-digit HUCs to create StreamStats data layers for the entire State. To calculate basin characteristics to develop the Iowa low-flow frequency and harmonic-meanflow regional regression equations, additional data layers were generated. These primary base-grid data layers include 

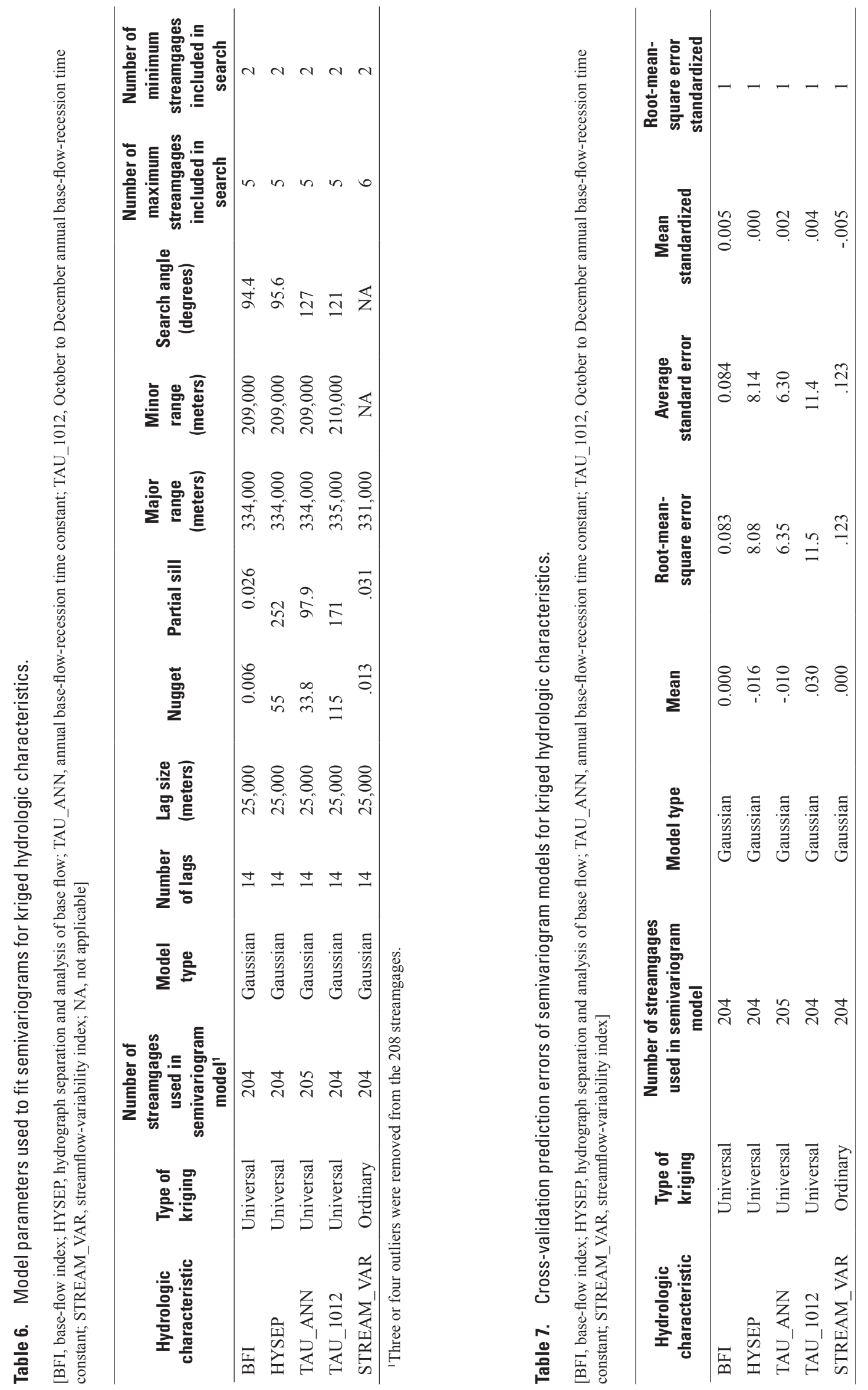


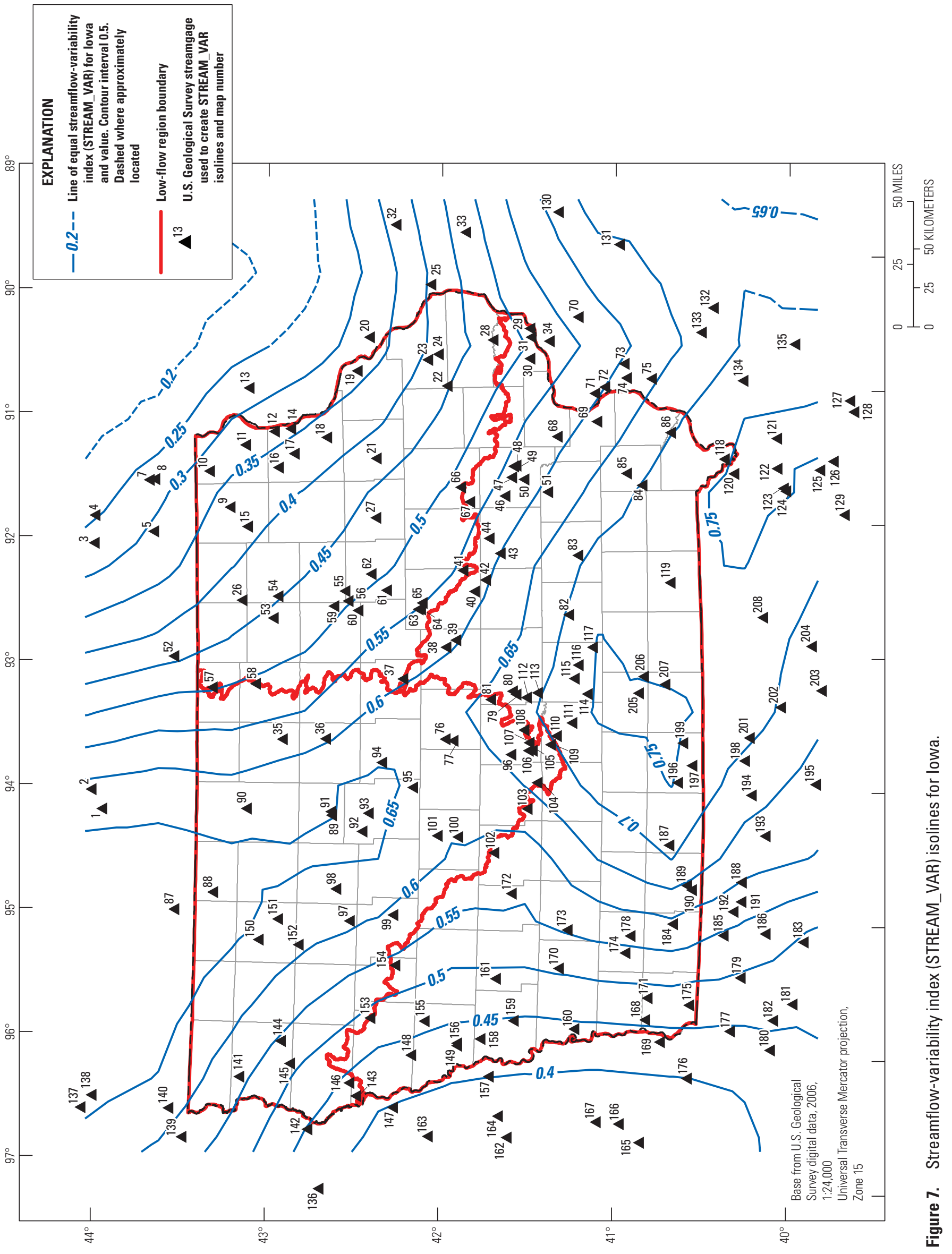




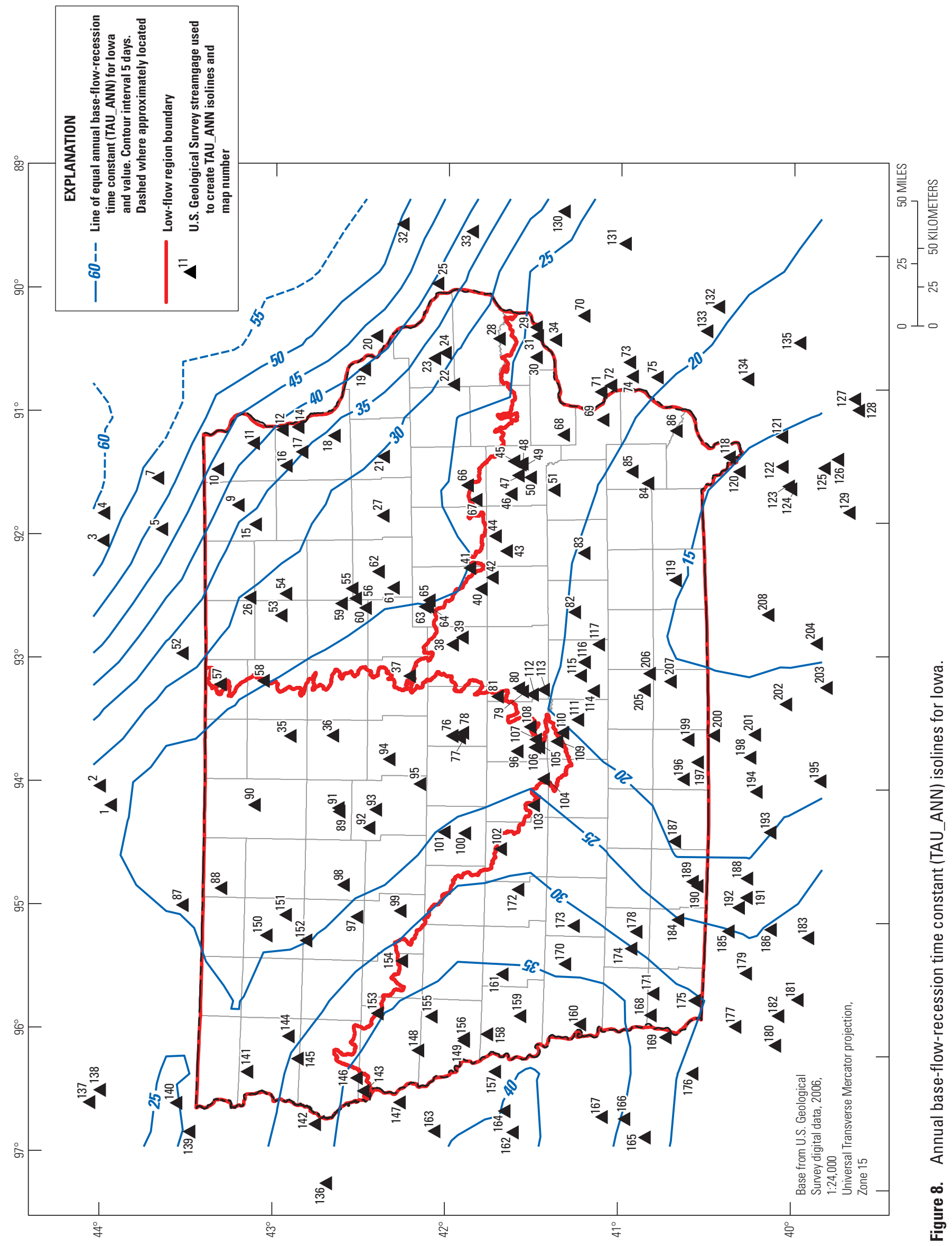




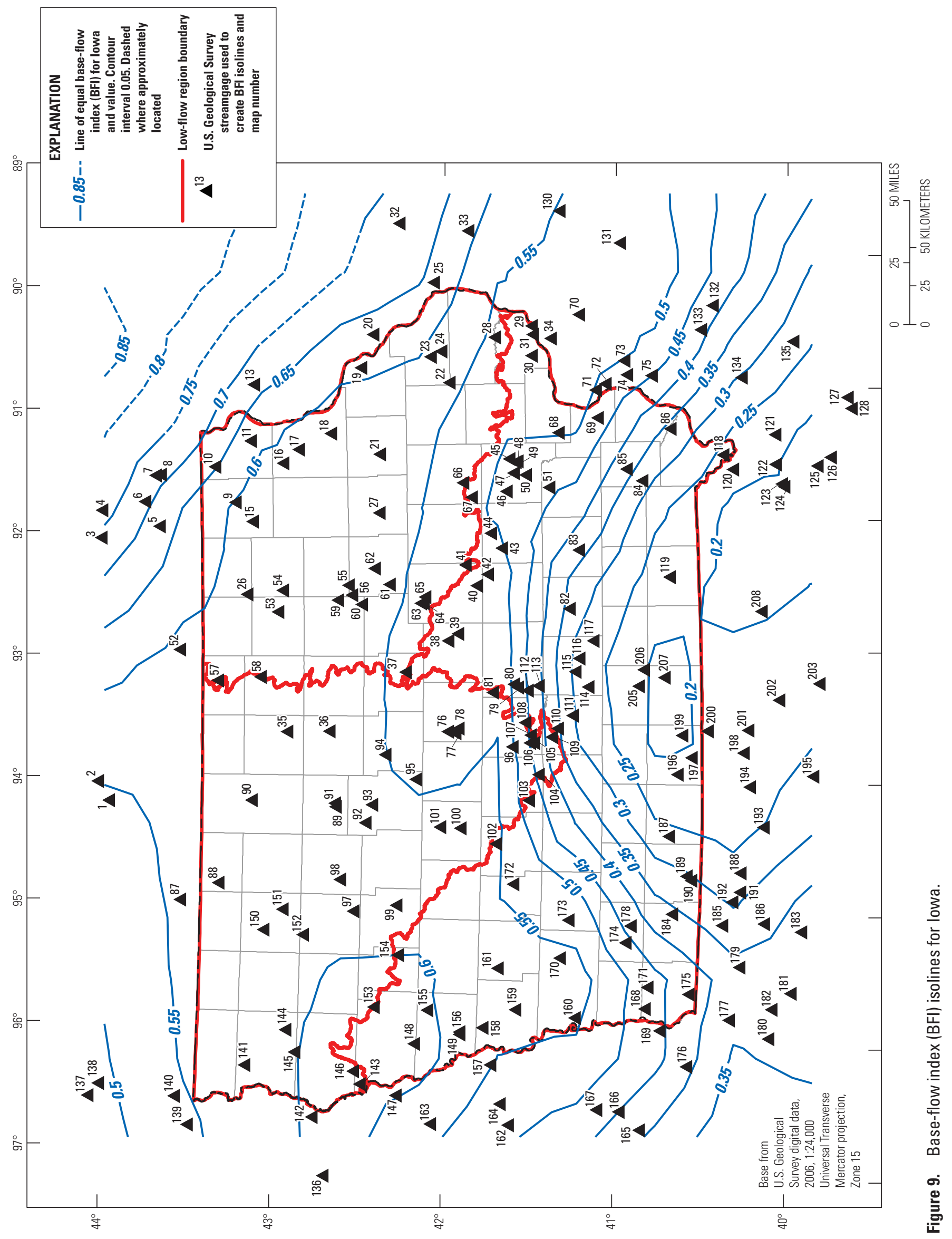


catchments, flow accumulation, flow direction, and an artificial flow-path grid used to delineate drainage basins. These additional layers then were used to create layers that control the StreamStats delineation of a watershed, subwatersheds, and stream networks within these watersheds, including the created layers named AdjointCatchment, Catchment, DrainageLine, DrainagePoint, LongestFlowPathCat, and LongestFlowPathAdjCat. Once processing was complete for all 58 processing units, a global geodatabase was created to direct StreamStats to how all units relate to each other. In addition, the DEM was resampled to $150 \mathrm{~m}$ for use in the basin-length calculations. All 54 basin characteristics listed in table 5 were measured using ArcHydro Tools or Spatial Analyst tools in ArcGIS, version 9.3 (Environmental Systems Research Institute, 2009).

In order to measure basin characteristics for streamgages located outside of Iowa, similar preprocessing steps were performed on GIS data layers for an additional twenty-seven 8-digit HUCs located in neighboring states. These 27 HUCs are not part of the GIS data layers used by StreamStats for Iowa. Because certified WBD data were not available at the time in adjacent states, the preprocessing of these 27 HUCs did not include the "walling" of basin boundaries using WBD; preprocessing did include the "burning" of streams from the NHD into the NED. However, a global geodatabase was not created for these 27 HUCs because none of the streamgages within these HUCs accumulated flow from more than one HUC.

GIS measurements of the five hydrologic basin characteristics (table 5) were interpolated by area-weighting values for streamgage watershed boundaries from grids that were created using a kriging procedure described in the previous section, Kriged Hydrologic Characteristics. GIS measurements of seven soil characteristics (table 5) were made using a threestep process. First, the NRCS Soil Data Viewer tool, built as an extension of ArcMap, was used to create four 8-digit HUC data layers for the soil characteristics. Second, a shapefile was created for the hydrosoils data layer (includes the four hydrologic soil types A, B, C, and D), and a grid was created for each of the SAND, CLAY, and KSATSSUR data layers. Third, the ARCMAP attribute selection tool was used to calculate a percent-area value for each hydrologic soil type, and the Spatial Analyst tool was used to calculate area-weighted values for SAND, CLAY, and KSATSSUR for each streamgage watershed boundary. The geologic characteristic DESMOIN, the land-use characteristic ROWCROP, and the 14 climatic characteristics (table 5) were all measured from grids as areaweighted values for each streamgage watershed.

Table 3 lists two drainage area values for each streamgage included in the study. Each streamgage has a drainage area that is listed in the USGS NWIS data base which is referred to as the "published" drainage area. Published drainage areas were determined primarily from 1:24,000-scale topographic maps by manual planimetering or GIS digitizing methods when streamgage operation began. Drainage area values listed in table 3 as "GIS" drainage area, for the basin characteristic DRNAREA, were measured as part of this study using a two-step process within ArcHydro Tools. First, a streamgage location was selected using the point generation tool and second, one of the watershed delineation tools (such as Batch Watershed Delineation) was used to automatically delineate the watershed boundary using hydro-corrected DEM data. The watershed delineation process in the second step delineates the basin boundary from the DEM data proceeding from the streamgage location until an existing basin boundary is reached within the WBD data and then the delineation follows the WBD boundary for the remainder of the watershed delineation. For some streamgages with small drainage areas that are located completely within a 12-digit HUC, the entire watershed delineation was made from the DEM data.

GIS delineations of watershed boundaries were inspected for streamgages with drainage area differences greater than 5 percent from published values. Basin boundaries of several GIS-delineated watersheds were edited where the delineation did not match well with digital raster graphics (DRG) elevation contours. Most edits made only a small difference in the drainage area value for the watershed. If the GIS-delineated basin boundary was accurate according to the 8-digit HUC, WBD line work, and DRG contour lines, then the GIS delineation was accepted even if it exceeded a 5-percent difference from the published drainage area. GIS delineations are generally believed to be more accurate than the published drainage areas. The majority of the GIS watershed delineations are using part of the WBD boundaries, which have been certified by NRCS, and use of the WBD data accounts for some of the differences between GIS and published values of drainage areas. GIS measurements of drainage area (DRNAREA) were used to develop the regression equations because StreamStats will use the same GIS data layers and delineation methods for determining watershed boundaries and drainage areas for ungaged stream sites. Drainage areas of the 208 streamgages ranged from 1.4 to $7,783 \mathrm{mi}^{2}$.

\section{Regional Regression Analyses to Estimate Selected Low-Flow Frequency Statistics and Harmonic Mean Flows for Ungaged Stream Sites}

In a regional regression study, subdividing a large study area into subregions that are relatively homogeneous in terms of low-flow hydrology typically helps to reduce error in the regression equations. Because low-flow regions have not been determined for Iowa in previous studies, preliminary statewide regression equations were initially developed for each of the seven selected statistics using all streamgages with low-flow frequency and harmonic-mean-flow statistic values greater than zero flow. Because linear regression analysis assumes a continuous response of streamflow to basin characteristics, streamgages with estimates of zero flow for the seven 
selected statistics cannot be used to estimate parameters of a linear regression model. Table 8 lists the significant variables identified and the predictive accuracies obtained for preliminary statewide regression equations initially developed for each of the seven selected statistics using ordinary-leastsquares (OLS) and subsequently finalized using weightedleast-squares (WLS) or generalized-least-squares (GLS) multiple-linear regression analyses (see following sections for further discussion of OLS, WLS, and GLS regression). The preliminary statewide low-flow frequency and harmonicmean-flow equations provided base-level predictive accuracies that regional regression equations can be compared against to evaluate improvement in accuracy. Because regional regression equations provided improved accuracies, the statewide equations were not developed further and are not listed in this report; they are summarized in table 8 to provide a reference showing the improvement obtained through regionalization.

\section{Definition of Low-Flow Regions}

Two streamgages were removed from the initial data set of 208 streamgages during the development of the statewide equations. The Iowa River at Wapello, Iowa, (streamgage 05465500, map number 69) was removed because of regulation, and the Big Nemaha Falls at Falls City, Nebr., (streamgage 06815000, map number 181) was removed because the drainage basin upstream from the streamgage extends outside of the 50-mi buffer of Iowa delineating the study area (table 9). These two streamgages are listed in tables $1-3$ because they were included in the kriging of the five hydrologic characteristics before being removed from the study; their inclusion or exclusion from the kriging data sets is not believed to significantly affect the kriging results.

Residual values (differences between low-flow frequency or harmonic-mean-flow statistics computed from observed streamflow and those predicted from the regression equations) from the preliminary statewide regression analyses were mapped at streamgage locations to identify spatial trends in the predictive accuracy of the regression equations. Differences in plotted residual values for the streamgages were grouped to define general low-flow regions within the study area. Streamgages were grouped into regression subsets on the basis of the low-flow regions, and OLS multiple-linear regression analyses were performed for each region. Because of the amount of variability in the residual mapping between the seven selected statistics, a cluster analysis method also was used to help define low-flow regions. A cluster analysis method called partitioning around medoids (PAM) using Spotfire S+ statistical software (TIBCO Software Inc., 2008) was used to define low-flow regions in Iowa. Cluster analysis is a statistical technique that was used to partition streamgages into groups (clusters) with similar streamflow or basin characteristics. The cluster analyses were based on the basin characteristics previously identified as significant variables in the preliminary statewide regression equations developed for each

Table 8. Significant explanatory variables and predictive accuracies of preliminary statewide regression equations.

[RMSE, root mean square error; Pseudo- ${ }^{2}$, pseudo coefficient of determination; SEP, average standard error of prediction; M1D10Y, annual 1-day mean low flow for a recurrence interval of 10 years; DRNAREA, GIS drainage area; $(+)$, explanatory variable has positive relation to the response variable; STREAM_VAR, streamflow-variability index; (-), explanatory variable has negative relation to the response variable; SOILDSSURGO, hydrologic soil type D; NA, not applicable; M7D10Y, annual 7-day mean low flow for a recurrence interval of 10 years; KSATSSUR, average soil permeability; M30D10Y, annual 30-day mean low flow for a recurrence interval of 10 years; CLAY, percent volume of clay content of soil; M30D5Y, annual 30-day mean low flow for a recurrence interval of 5 years; PRC8, mean August precipitation; M1D10Y1012, seasonal (October through December) 1-day mean low flow for a recurrence interval of 10 years; PRECIP, mean annual precipitation; M7D10Y1012, seasonal (October through December) 7-day mean low flow for a recurrence interval of 10 years; QAH, harmonic mean flow]

\begin{tabular}{|c|c|c|c|c|c|}
\hline Statistic & $\begin{array}{l}\text { Number of streamgages } \\
\text { used to develop } \\
\text { preliminary equation' }\end{array}$ & $\begin{array}{l}\text { Most significant explanatory variables identified } \\
\text { for the preliminary equation and } \\
\text { explanatory-variable relation signs }\end{array}$ & $\begin{array}{c}\text { RMSE } \\
\text { (percent) }\end{array}$ & $\begin{array}{c}\text { Pseudo-R }^{2} \\
\text { (percent) }\end{array}$ & $\begin{array}{c}\text { SEP } \\
\text { (percent) }\end{array}$ \\
\hline \multicolumn{6}{|c|}{ Preliminary generalized least-squares regression analyses results } \\
\hline M1D10Y & 158 & DRNAREA(+), STREAM_VAR(-), SOILDSSURGO(-) & NA & 79.9 & 157.5 \\
\hline M7D10Y & 166 & DRNAREA(+), STREAM_VAR(-), KSATSSUR(+) & NA & 81.1 & 149.8 \\
\hline M30D10Y & 180 & DRNAREA(+), STREAM_VAR(-), CLAY(-) & NA & 87.3 & 114.6 \\
\hline M30D5Y & 187 & DRNAREA(+), STREAM_VAR(-), PRC8(+) & NA & 89.2 & 96.8 \\
\hline M1D10Y1012 & 177 & DRNAREA(+), STREAM_VAR(-), PRECIP(+) & NA & 86.9 & 109.0 \\
\hline M7D10Y1012 & 179 & DRNAREA(+), STREAM_VAR(-), KSATSSUR(+) & NA & 90.0 & 83.9 \\
\hline \multicolumn{6}{|c|}{ Preliminary weighted least-squares regression analysis results } \\
\hline QAH & 206 & DRNAREA(+), STREAM VAR(-), CLAY(-) & 93.6 & NA & 294.5 \\
\hline
\end{tabular}

${ }^{1}$ Streamgages with estimates of zero flow were excluded from the regression analysis.

${ }^{2}$ Based on mean-square error residuals. 
Table 9. Streamgages removed from regional-regression analyses.

[USGS, U.S. Geological Survey. Streamgage locations are shown in figure 1]

\begin{tabular}{ccll}
\hline $\begin{array}{c}\text { Map } \\
\text { number }\end{array}$ & $\begin{array}{c}\text { USGS } \\
\text { streamgage } \\
\text { number }\end{array}$ & \multicolumn{1}{c}{ Streamgage name } & \multicolumn{1}{c}{$\begin{array}{l}\text { Reason for removal of streamgage from regression analy- } \\
\text { ses }\end{array}$} \\
\hline 29 & 05422470 & Crow Creek at Bettendorf, Iowa & Urbanization. \\
69 & 05465500 & Iowa River at Wapello, Iowa & $\begin{array}{l}\text { Regulation from upstream dam. } \\
\text { Diversion by City of Ames for water supply. }\end{array}$ \\
78 & 05471000 & $\begin{array}{l}\text { South Skunk River below Squaw Creek near } \\
\text { Ames, Iowa }\end{array}$ & Regulation from Yankton, Long, Shetek and Heron Lakes. \\
87 & 05476000 & Des Moines River at Jackson, Minn. & Diversion by City of Des Moines for water supply. \\
105 & 05484650 & Raccoon River at 63rd Street at Des Moines, Iowa & Urbanization. \\
106 & 05484800 & Walnut Creek at Des Moines, Iowa & Diversion by City of Des Moines for water supply. \\
107 & 05484900 & Raccoon River at Fleur Drive, Des Moines, Iowa & Diversion by City of Ankeny for water supply. \\
108 & 05485640 & Fourmile Creek at Des Moines, Iowa & Large gravel-quarry operation about 1-mile upstream. \\
140 & 06482610 & Split Rock Creek at Corson, S. Dak. & Regulation from many upstream impoundment dams. \\
157 & 06608000 & Tekamah Creek at Tekamah, Nebr. & Diversion for irrigation. \\
162 & 06799385 & Pebble Creek at Scribner, Nebr. & Diversion for irrigation. \\
163 & 06799450 & Logan Creek at Pender, Nebr. & Diversion for irrigation. \\
164 & 06799500 & Logan Creek near Uehling, Nebr. & Regulation from flood-control and grade-stabilization \\
169 & 06806500 & Weeping Water Creek at Union, Nebr. & structures. \\
176 & 06810500 & Little Nemaha River near Syracuse, Nebr. & Diversion for irrigation. \\
181 & 06815000 & Big Nemaha Falls at Falls City, Nebr. & Drainage basin extends outside 50-mile buffer used for \\
& & & study area. \\
\hline
\end{tabular}

of the seven selected statistics (table 8). Drainage area was not included in the analyses because it is not a unique characteristic for any one cluster. The PAM method of cluster analysis uses medoids instead of centroids to form groups for which average dissimilarity of basin-characteristic values in each group are minimal (http://www.unesco.org/webworld/idams/ advguide/Chapt7_1_1.htm, accessed April 8, 2011). Cluster analyses resulted in two to three well-defined groups, which along with the residual mapping, helped to define a significant difference between the southern and northern areas of the State and between the northeastern and northwestern areas of the State.

Streamgages then were grouped into several two- and three-region data sets on the basis of Iowa's landform regions. Analysis-of-covariance regression (Helsel and Hirsch, 2002) was used to test each region for statistically significant differences by comparing the intercept for each region's regression model to that for the rest of the study area by assigning a location variable for each region. Each location-indicator variable was set at 1 if the streamgage was in a particular region, or 0 if the streamgage was not in a particular region. A two-variable OLS regression analysis that included drainage area and the location-indicator variable was performed statewide for each of the seven selected statistics for each of the low-flow regions being tested. Statistical significance for each region was determined using a 95-percent confidence level. Statistical significance for the location-indicator variable indicates a difference in the regression intercept between streamgages in that region and streamgages in the rest of the study area. Several two- and three-region combinations were determined to be significantly different from each other, and preliminary regional regression equations were developed for several of the selected low-flow frequency statistics for each of these regional combinations.

Comparisons of the preliminary regional regression analyses indicated improved overall predictive accuracies by subdividing the State into three regions rather than two regions. The goal of the regionalization analyses was to define the best overall regions for all seven selected statistics and to have an adequate number of streamgages (preferably, at least 30) in each regional data set for the regression analyses. Streamgages flagged as outliers (high leverage or high influence points) in the GLS or WLS regression analyses, using a weighted-multiple-linear regression program (WREG) (Eng and others, 2009), were reviewed for inaccurate data and for possible effects of urbanization, regulation, or diversion. In addition to the two streamgages previously removed from the low-flow frequency and harmonic-mean-flow regression data sets, 14 additional streamgages, which were flagged as outliers, also were removed from the regression data sets (table 9). These 14 streamgages were removed because streamflow at these sites were identified by field personnel in their respective 
States, who were familiar with the sites, as possibly being affected by anthropogenic alterations. All other streamgages that were flagged as outliers were kept in the regression data sets because there was no justification for removing them. Thus, a total of 192 streamgages were considered to have unaltered streamflow for the regional regression analyses. All 192 of these streamgages have at least 10 years of record that can be used for the development of the two fall season lowflow frequency and the harmonic-mean-flow equations. Of the 192 streamgages, five have only 9 years of annual climatic record, thus, only a total of 187 streamgages were used for the development of the four annual low-flow frequency equations.

Three low-flow regions (northeast, northwest, and southern) were defined for Iowa after testing a number of different regional combinations. The three low-flow regions were then tested using two slightly different groupings of streamgages; first on the basis of a strict definition of landform-region boundaries, and second on the basis of residuals defining low-flow regional boundaries for streamgages located close to landform-region boundaries. Predictive accuracies were improved for regions defined on the basis of residuals compared to regions defined on the basis of strict landform-region boundaries, which appears reasonable because low-flow regional boundaries are not actually distinct lines, but the boundaries are transition zones where the hydrologic characteristics of one region transition to the hydrologic characteristics of another region. Figure 1 shows the three low-flow regions defined for Iowa for the development of final regional regression equations. Low-flow regional boundaries were defined along 12-digit WBD HUC boundaries to avoid drawing a low-flow region boundary through a HUC polygon. For a 12-digit HUC that overlies a landform region boundary, the low-flow region boundary was drawn to include the landform region that comprises the majority of the 12-digit HUC area.

The northeast low-flow region is defined by the Iowan Surface, the Paleozoic Plateau, and the East-Central Iowa Drift Plain landform regions and contains approximately 24 percent of the total land area of the State (fig. 3). The northeast low-flow region generally has shallower loess deposits, more bedrock outcropping, more springs, higher soil-permeability rates, and greater sustained base flow than the other two lowflow regions (figs. 2 and 7). The northwest low-flow region is defined by the Des Moines Lobe and the Northwest Iowa Plains landform regions and contains approximately 30 percent of the total land area of the State (fig. 3). The northwest low-flow region generally has lower relief than the other two low-flow regions. The southern low-flow region is defined by the Southern Iowa Drift Plain, the Loess Hills, the IowaCedar Lowland, and the Mississippi River and Missouri River Alluvial Plains landform regions and contains approximately 46 percent of the total land area of the State (fig. 3). The southern low-flow region generally has deeper loess deposits and lower soil-permeability rates compared to the other two low-flow regions (fig. 2).

\section{Development of Regional Regression Equations}

Because a significant number of streams in Iowa have zero flow as their minimum flow during low-flow years, four types of regression analyses were performed to develop the final equations for the three low-flow regions-left-censored, logistic-, WLS-, and GLS-regression analyses. For the northeast and northwest regions, left-censored regression analyses were performed to allow the use of a censoring threshold $\left(0.1 \mathrm{ft}^{3} / \mathrm{s}\right)$ in the development of equations to estimate the six low-flow frequency statistics (M1D10Y, M7D10Y, M30D10Y, M30D5Y, M1D10Y1012, and M7D10Y1012). A WLS multiple-linear regression analysis, weighted on the basis of streamgage record length, was used to develop an equation to estimate QAH for the northeast and northwest regions. For the southern region, logistic regression analyses were performed to develop equations to estimate the probability of zero flow for the six low-flow frequency statistics. GLS multiple-linear regression analyses, weighted on the basis of streamgage record length and the variance and cross-correlation of the annual low flows, were used to develop six equations to estimate nonzero low-flow frequency statistics. Again, WLS regression analysis was used to develop an equation to estimate QAH for the southern region.

Differences in the percentage of streamgages with estimates of zero flow, computed from observed streamflow for the six low-flow frequency statistics, between the northern and southern regions of the State required the use of different regression analyses. The percentage of streamgages with estimates of zero flow computed from observed streamflow for each selected statistic for each region are listed in the shaded columns in table 10. Estimates of zero flow computed from observed streamflow are often considered to be censored data (Kroll and Stedinger, 1996; Kroll and Vogel, 2002), and the use of multiple-linear regression is not recommended for censored data (Helsel and Hirsch, 2002). Thus, two types of censored-regression methods were used in the development of equations to estimate the six low-flow frequency statistics. The choice of censored-regression methods depends on the amount of censoring in each region for each low-flow frequency statistic (Helsel and Hirsch, 2002). If less than 20 percent of the observed low-flow frequency statistic was zero flow, then a left-censored regression method was used because a censoring threshold only applies to the low-end of the low-flow frequency statistics. If between 20 to 50 percent of the observed low-flow frequency statistic was zero flow, then a logistic regression method was used to first estimate the probability of zero flow at ungaged sites and then, if necessary, multiple-linear regression is used to estimate low-flow frequency statistics for sites that logistic-regression equations estimate are likely to have flow.

Estimates of zero flow computed from observed streamflow are less than 20 percent in the northeast and northwest regions for the six low-flow frequency statistics and are generally within the 20 to 50 percent range for the southern region (table 10). Although zero flows are not estimated for 
any streamgages in the northeast region for two low-flow frequency statistics (M30D10Y and M30D5Y), and multiplelinear regression is applicable, left-censored regression was used to develop all six low-flow frequency equations. Likewise, for the southern region where zero flow estimates are less than 20 percent for two low-flow frequency statistics (M30D10Y and M30D5Y), and left-censored regression is preferred, logistic regression was used to develop all six lowflow frequency equations. For both regions, the same regression method was used to develop all six low-flow frequency equations to avoid the possibility of inconsistencies in estimates, such as an estimate of M7D10Y exceeding an estimate of M30D10Y. Because there were no zero flows computed from observed streamflow for QAH, standard multiple-linear regression analyses were used to develop an equation for each region for estimating QAH.

\section{Multiple-Linear Regression}

Multiple-linear-regression analysis is the most common method used to develop equations for the estimation of streamflow statistics at ungaged sites. Multiple-linear regression models the relation between two or more basin characteristics (called explanatory or independent variables) and a streamflow statistic (called a response or dependent variable) by fitting a linear equation to the data. Every value of each basin characteristic is associated with the value of the streamflow statistic. Upon the development of regression equations, measurements of the basin characteristics at ungaged stream locations can be used to estimate the streamflow statistic.
The general form of equations developed from multiplelinear-regression analysis is:

$$
Y_{i}=b_{0}+b_{1} X_{1}+b_{2} X_{2}+\ldots+b_{n} X_{n}+e_{i}
$$

where

$$
\begin{array}{cc}
Y_{i} \quad \begin{array}{c}
\text { is the response variable (estimate of the } \\
\text { streamflow statistic computed from } \\
\text { observed streamflow) for site } i, \\
X_{1} \text { to } X_{n}
\end{array} \\
\begin{array}{c}
\text { are the } n \text { explanatory variables (basin } \\
\text { characteristics) for site } i,
\end{array} \\
b_{0} \text { to } b_{n} \quad \begin{aligned}
\text { are the } n+1 \text { regression model coefficients, } \\
\text { and }
\end{aligned} \\
\quad \begin{array}{c}
\text { is the residual error (difference between } \\
\text { the observed and predicted values of the } \\
\text { response variable) for site } i .
\end{array}
\end{array}
$$

Assumptions for the use of regression analyses are: (1) the model adequately describes the linear relation between the response and explanatory variables, (2) the mean of $e_{i}$ is zero, (3) the variance of $e_{i}$ is constant and independent of the values of $X_{n}$, (4) the values of $e_{i}$ are normally distributed, and (5) the values of $e_{i}$ are independent of each other (Iman and Conover, 1983). Because streamflow data are naturally correlated spatially and temporally, assumption 5 is not completely satisfied with the use of OLS. As a result, WLS regression was used to develop the final equations for estimating QAH, and GLS regression was used to develop the final equations for estimating selected low-flow frequency statistics for the southern region. A general overview of the OLS, WLS, and

\begin{tabular}{|c|c|c|c|c|c|c|c|c|c|}
\hline \multirow[t]{2}{*}{ Statistic } & \multicolumn{3}{|c|}{$\begin{array}{l}\text { Northeast region ( } \mathrm{N}=43 \text { for annual- } \\
\text { frequency analyses; } \mathrm{N}=44 \text { for fall- } \\
\text { frequency and } \mathrm{QAH} \text { analyses*) }\end{array}$} & \multicolumn{3}{|c|}{$\begin{array}{l}\text { Northwest region ( } \mathrm{N}=37 \text { for annual- } \\
\text { frequency analyses; } \mathrm{N}=38 \text { for fall- } \\
\text { frequency and } \mathrm{QAH} \text { analyses }{ }^{*} \text { ) }\end{array}$} & \multicolumn{3}{|c|}{$\begin{array}{l}\text { Southern region ( } \mathrm{N}=107 \text { for annual- } \\
\text { frequency analyses; } \mathrm{N}=110 \text { for fall- } \\
\text { frequency and } \mathrm{OAH} \text { analyses*) }\end{array}$} \\
\hline & $\begin{array}{c}N \text { with } \\
0>0\end{array}$ & $\begin{array}{c}N \text { with } \\
0=0\end{array}$ & $\begin{array}{c}\mathbf{0}=\mathbf{0} \\
\text { (percent) }\end{array}$ & $\begin{array}{c}N \text { with } \\
0>0\end{array}$ & $\begin{array}{c}N \text { with } \\
0=0\end{array}$ & $\begin{array}{c}0=0 \\
\text { (percent) }\end{array}$ & $\begin{array}{c}N \text { with } \\
0>0\end{array}$ & $\begin{array}{c}N \text { with } \\
\mathbf{Q}=\mathbf{0}\end{array}$ & $\begin{array}{c}0=0 \\
\text { (percent) }\end{array}$ \\
\hline M1D10Y & 40 & 3 & 7 & 31 & 6 & 16 & 75 & 32 & 30 \\
\hline M7D10Y & 41 & 2 & 5 & 32 & 5 & 14 & 80 & 27 & 25 \\
\hline M30D10Y & 43 & 0 & 0 & 34 & 3 & 8 & 90 & 17 & 16 \\
\hline M30D5Y & 43 & 0 & 0 & 35 & 2 & 5 & 96 & 11 & 10 \\
\hline M1D10Y1012 & 43 & 1 & 2 & 35 & 3 & 8 & 86 & 24 & 22 \\
\hline M7D10Y1012 & 43 & 1 & 2 & 35 & 3 & 8 & 88 & 22 & 20 \\
\hline QAH & 44 & 0 & 0 & 38 & 0 & 0 & 110 & 0 & 0 \\
\hline
\end{tabular}
GLS multiple-linear regression techniques used to develop the

Table 10. Percentage of streamgages with estimates of zero flow computed from observed streamflow for selected low-flow frequency statistics and harmonic mean flows in each region of lowa.

$[\mathrm{N}$, number of streamgages; QAH, harmonic mean flow; *differences in the number of streamgages between annual- and fall-frequency analyses is because some annual-climatic records only have 9 years of record, and these streamgages were not included in the development of annual-frequency equations; Q, lowflow estimate computed from observed streamflow (cubic feet per second); >, greater than; M1D10Y, annual 1-day mean low flow for a recurrence interval of 10 years; shaded column, the percentage of streamgages with estimates of zero flow computed from observed streamflow for each selected statistic for the region; M7D10Y, annual 7-day mean low flow for a recurrence interval of 10 years; M30D10Y, annual 30-day mean low flow for a recurrence interval of 10 years; M30D5Y, annual 30-day mean low flow for a recurrence interval of 5 years; M1D10Y1012, seasonal (October through December) 1-day mean low flow for a recurrence interval of 10 years; M7D10Y1012, seasonal (October through December) 7-day mean low flow for a recurrence interval of 10 years] 
initial and final equations is presented in the following three sections.

\section{Ordinary-Least-Squares Regression}

OLS regression analyses were used to develop initial multiple-linear regression equations, or models, for all seven selected statistics. Final equations were developed using WLS, GLS, or censored regression procedures. OLS regression analyses were used to identify the best combinations of basin characteristics to use as explanatory variables in the development of regression models and to define the low-flow regions.

Logarithmic transformations (base 10) were performed for all response variables and for selected explanatory variables used in the OLS, WLS, GLS, and censored regression analyses. Data transformations, other than logarithmic transformations, also were used for selected explanatory variables to obtain a more constant variance of the residuals about the regression line and to linearize the relation between the response variable and the explanatory variables. The response variable is assumed to be a linear function of one or more explanatory variables. A base- 10 logarithmic transformation has the form of:

$$
\log Y_{i}=b_{0}+b_{1} \log X_{1}+b_{2} \log X_{2}+\ldots+b_{n} \log X_{n}+e_{i}
$$

When equation 7 is retransformed back to its original units, it is algebraically equivalent to:

$$
Y_{i}=10^{b o} X_{1}^{b 1} X_{2}^{b 2} \ldots X_{n}^{b n} 10^{e i}
$$

Several basin characteristics were deleted from the original regression data set of 54 basin characteristics because of multicollinearity. Multicollinearity is the condition wherein at least one explanatory variable is closely related to (that is, not independent of) one or more other explanatory variables. Regression models that include variables with multicollinearity may be unreliable because coefficients in the models may be unstable. Correlation coefficients greater than 0.5 , or less than -0.5 , and plots of the data were used as guides in identifying variables with multicollinearity. The hydrologic validity of variables with multicollinearity in the context of low flows or the harmonic mean flow was the principal criterion used in determining which basin characteristics were deleted from the data set.

OLS regression analyses were performed using Spotfire S+ statistical software (TIBCO Software Inc., 2008). Initial selections of significant explanatory variables for the OLS regression models were performed using the Efroymson stepwise-selection method (Efroymson, 1960). The Efroymson method is an automatic procedure for regression model selection when there are a large number of potential explanatory variables. The procedure is similar to forward selection, which tests basin characteristics one by one and identifies those that are statistically significant, except as each new basin characteristic is identified as being significant, partial correlations are checked to see if any previously identified variables can be deleted (Ahearn, 2010). When basin characteristics were found to be highly correlated to each other, only one basin characteristic at a time was tested in the Efroymson selection process.

The Efroymson analyses produced a subset of potential significant basin characteristics for each selected statistic. Each subset of basin characteristics was then iteratively tested using standard OLS regression analyses to identify several sets of the best equations (regression models) that contained no more than three significant explanatory variables (basin characteristics). A limit of three explanatory variables per equation was used to minimize overfitting of the regression models. Results of the OLS models were evaluated to determine their adequacy, including graphical relations and residual plots, variance inflation factor (VIF), Cook's D statistic (Cook, 1977; Helsel and Hirsch, 2002), high-leverage points, the average standard error of estimate (SEE), and the adjusted coefficient of determination (adj-R ${ }^{2}$ ) (Helsel and Hirsch, 2002). The selection of explanatory variables, and the signs and magnitudes of their respective regression coefficients, were each evaluated to ensure hydrologic validity in the context of low-flow frequency and the harmonic mean flow. This criterion takes precedence over all other criteria. All explanatory variables selected by OLS regression in this study were statistically significant at the 95-percent confidence level. Explanatory variables were selected to minimize SEE and to maximize the adj- $\mathrm{R}^{2}$. SEE is a measure of the fit of the observed data to the regression model (difference between the value of the observed streamflow statistic and the value of the predicted streamflow statistic) and of the error inherent in the regression model; SEE also is referred to as the root mean square error (RMSE). Adj- $\mathrm{R}^{2}$ is a measure of the proportion of the variation in the response variable that is explained by the explanatory variables and adjusted for the number of streamgages and explanatory variables used in the analysis. Correlation between explanatory variables and VIF (Marquardt, 1970; Helsel and Hirsch, 2002) was used to assess multicollinearity in the regression models. Multicollinearity problems were identified with a regression-diagnostics tool implemented in the USGS library version 4.0 (Lorenz and others, 2011) for Spotfire S+ statistical software (TIBCO Software Inc., 2008) by checking each explanatory variable for VIF greater than 2 .

\section{Weighted-Least-Squares Regression}

WLS multiple-linear regression was used to develop one regression equation for each of the three low-flow regions for estimating QAH because estimates of QAH at all 192 streamgages (tables 2 and 10) were greater than zero flow. Tasker (1980) reports that OLS regression assumes that the time-sampling variance in the response-variable estimates are the same for each streamgage used in the analysis (assumption of homoscedasticity); implying that all observations of the response variable are equally reliable. In hydrologic regression, this assumption is usually violated because the reliability of response-variable estimates depends primarily on the length 
of the observed streamflow records. WLS regression adjusts for the variation in the reliability of the response-variable estimates by using a weight for each streamgage to account for differences in the lengths of streamflow records. WLS regression analyses were performed using the WREG program (Eng and others, 2009). A customized, user-defined weighting matrix was used to weight streamgages in each low-flow region for application of WREG for the development of QAH regression equations. Each regional weighting matrix was created on the basis of record length, computed as the number of years of record at the streamgage divided by the average number of years of record of all streamgages in the regression data set. Thus, short-record streamgages received reduced weight in the regression analyses, and long-record streamgages received increased weight. The sum of the weights assigned to each streamgage in each region equaled the total number of streamgages included in the WLS regression analysis for each region. WLS models were selected for use over the OLS models for the development of the three regional QAH equations because increased weight is given to response-variable estimates with long record lengths, and thus, presumably, the WLS equations have improved accuracy. Final WLS regression models were selected primarily on the basis of minimizing values of the SEE and the average standard error of prediction (SEP). (GLS regression, described in the next section, is not applicable to the QAH statistic, because it is not a frequency-based statistic with an annual probability estimated, but it is a singular value computed directly from all the daily mean flow values for the streamgage period of record. Weights within GLS regression are derived from, in addition to the length of record, the annual flow variability and correlation of annual flows among streamgages, which affect the amount of new, independent information contributed by each streamgage included in the regression.)

\section{Generalized-Least-Squares Regression}

GLS multiple-linear regression was used to develop six regression equations for estimating selected low-flow frequency statistics for the southern region because the percentage of streamgages in this region with estimates of zero flow computed from observed streamflow was greater than 20 percent for the majority of the low-flow frequencies (table 10). GLS regression analyses were performed using the WREG program (Eng and others, 2009). GLS regression, as described by Stedinger and Tasker (1985), Tasker and Stedinger (1989), and Griffis and Stedinger (2007), is a method that weights streamgages in the regression according to differences in streamflow reliability (record lengths) and variability (record variance) and according to spatial cross correlations of concurrent streamflow among streamgages. Compared to OLS regression, GLS regression provides improved estimates of streamflow statistics and improved estimates of the predictive accuracy of the regression equations (Stedinger and Tasker, 1985). Compared to WLS regression, GLS regression may not be as appropriate for the development of equations for the estimation of low-flow frequency statistics if a set of basin characteristics cannot be identified that describes most of the variability of the low-flow frequency statistics (Ken Eng, U.S. Geological Survey, written commun., 2007). GLS regression is considered more appropriate than WLS regression if low-flow regression data are highly correlated spatially, as was the case for Iowa low-flow data (Ken Eng, U.S. Geological Survey, written commun., 2009). The correlation smoothing function used by the WREG program to compute a weighting matrix for the 81 streamgages included in the development of the GLS regression equation for estimating M7D10Y for the southern region with 30 years of concurrent flow is shown in figure 10. The smoothing function relates the correlation between annual low-flow time series at two streamgages to the geographic distance between the streamgages for every paired combination of the 81 streamgages with 30 years of concurrent flow data (annual series of minimum 7-day mean low flows for all streamgages in the southern region is shown in figure 10). Strong evidence of cross correlation is shown in figure 10, justifying the use of GLS regression over WLS regression, because of the abundance of paired points for 30 years of concurrent flow that form the long tail extending towards the bottom right side of the graph. Final GLS regression models were selected primarily on the basis of minimizing values of the standard error of model (SEM) and the SEP and maximizing values of the pseudo- $\mathrm{R}^{2}$. The pseudo- $\mathrm{R}^{2}$, or pseudo coefficient of determination, is a measure of the percentage of the variation explained by the basin characteristics (explanatory variables) included in the model. The pseudo- $\mathrm{R}^{2}$ value is calculated on the basis of the degrees of freedom in the regression (Griffis and Stedinger, 2007).

\section{Left-Censored Regression}

Left-censored regression, also referred to as Tobit regression, was used to develop six equations for both the northeast and northwest regions; because the number of streamgages in these regions with estimates of zero flow for low-flow frequencies computed from observed streamflow was less than 20 percent (table 10). Censored and uncensored response data can be included together in a censored-regression analysis. Censored regression is similar to multiple-linear regression, except that the regression coefficients are fit by maximum-likelihood estimation (MLE) (Helsel and Hirsch, 2002). MLE is comparable to a curve-matching process, in which a probability distribution is best matched to the observed data. MLE assumes that residuals are normally distributed around the regression line for the estimation of the slope and intercept, and the range of predicted values has constant variance. Additional information on MLE is presented in Helsel and Hirsch (2002) and in Runkel and others (2004). Cohn (1988) has shown that censored regression estimates are slightly biased, and an adjustment for first-order bias in these estimates is made by an adjusted maximum-likelihood estimation (AMLE) computation. An AMLE procedure implemented in the USGS computer-program library version 4.0 (Lorenz and others, 2011) for Spotfire 


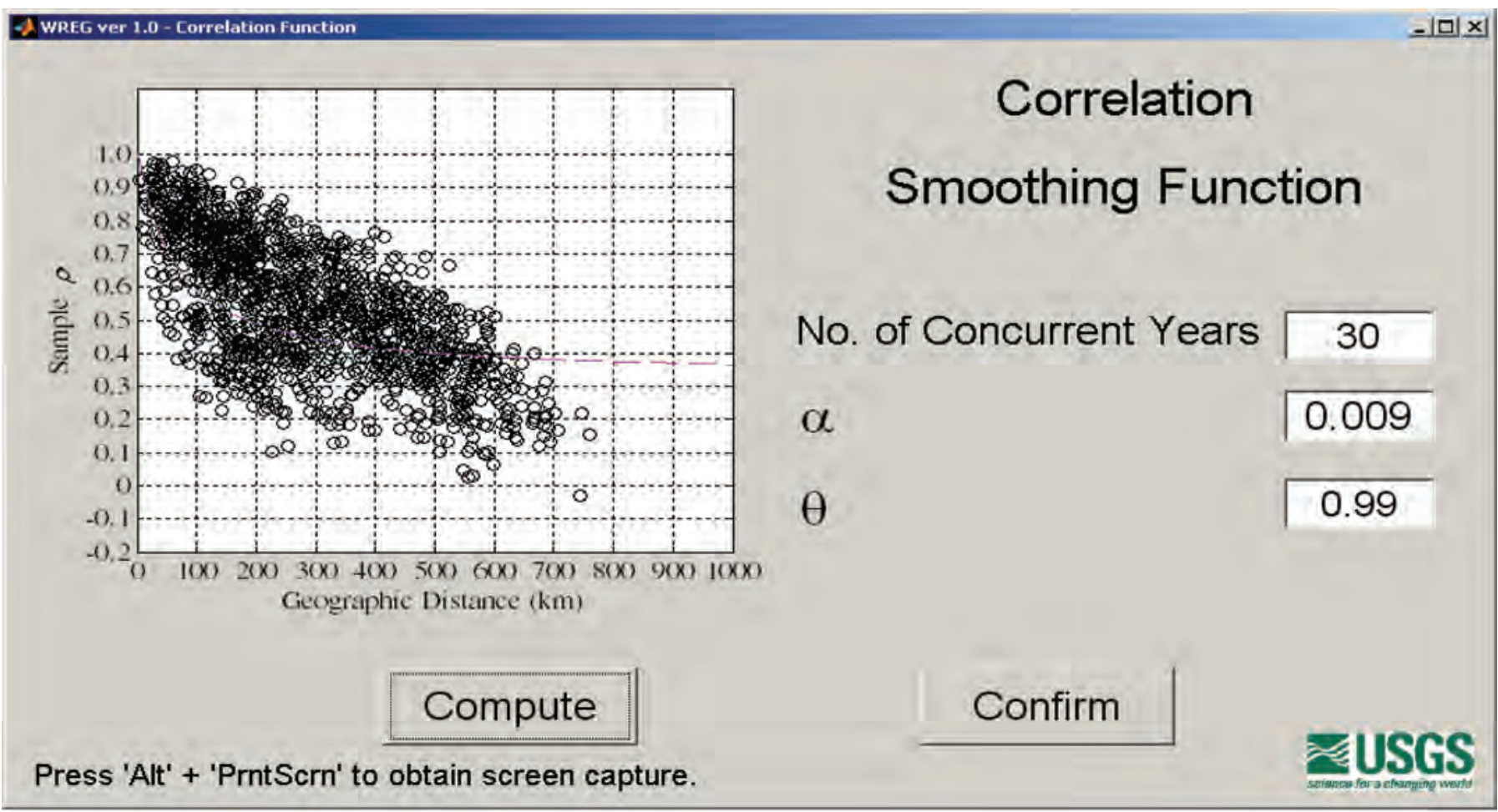

Figure 10. Screenshot of the weighted-multiple-linear regression program (WREG) smoothing function for generalized-least squares (GLS) correlation of the time series of annual minimum 7-day mean flows as a function of distance between 81 streamgages in the southern region with 30 years of concurrent flow.

S+ statistical software (TIBCO Software Inc., 2008) was used to develop the left-censored regression equations in this study. A censoring threshold of $0.1 \mathrm{ft}^{3} / \mathrm{s}$ was used to censor small response-variable discharges and zero flows estimated for the six low-flow frequency statistics. A censoring threshold is applied only to small values; thus the method is referred to as left-censored regression.

Daily mean discharge values are recorded for streamgages as low as $0.01 \mathrm{ft}^{3} / \mathrm{s}$ and low-flow frequency estimates less than $0.01 \mathrm{ft}^{3} / \mathrm{s}$ are computed from observed streamflow (table 2). Because of the uncertainty in measuring daily mean discharges and estimating low-flow frequencies below $0.1 \mathrm{ft}^{3} / \mathrm{s}$, a censoring threshold set at $0.1 \mathrm{ft}^{3} / \mathrm{s}$ was used to develop the left-censored regression equations for this study. Thus, in addition to the censoring of zero flows, low-flow frequency estimates computed from observed streamflow less than or equal to $0.1 \mathrm{ft}^{3} / \mathrm{s}$ also were censored in the regression analyses. Final left-censored regression models were selected primarily on the basis of minimizing values of the SEE.

\section{Logistic Regression}

Logistic regression analysis was used to develop six regression equations for the southern region to estimate the probability of zero flow because the number of streamgages in this region with low-flow frequency estimates of zero flow was greater than 20 percent for the majority of the low-flow frequencies (table 10). For the logistic regression performed in this study, the response variable is binary or categorical; a response value of zero was assigned to streamgages with estimates of zero flow for low-flow frequencies computed from observed streamflow and a response value of one was assigned to streamgages with estimates greater than zero for low-flow frequencies. The probability of the response variable being in one category or the other is tested to determine if it differs as a function of continuous explanatory variables (Helsel and Hirsch, 2002). Predictions from logistic regression will fall between zero and one and are understood as the probability (p) of observing a response of one (predicts flow at ungaged site to be greater than zero). Therefore, $(1-p)$ is the probability of observing a response of zero (predicts zero flow at ungaged site). Recent applications of logistic regression that are specific to low-flow studies can be found in Martin and Arihood (2010), Funkhouser and others (2008), Hortness (2006), and Bent and Steeves (2006). The logistic regression analyses were computed using Spotfire $\mathrm{S}+$ statistical software (TIBCO Software Inc., 2008). The form of the logistic regression equation is:

$$
P_{z e r o}=1-\left(\frac{e^{a_{0}+c_{1} V_{1}+\ldots+c_{n} V_{n}}}{1+e^{a_{0}+c_{1} V_{1}+\ldots+c_{n} V_{n}}}\right)
$$


where

$$
\begin{gathered}
P_{\text {zero }} \quad \begin{array}{r}
\text { is the probability of the low-flow frequency } \\
\text { statistic being equal to zero, }
\end{array} \\
a_{0} \quad \begin{array}{r}
\text { is the regression model constant, } \\
e
\end{array} \text { is the base of the natural logarithm and is } \\
\text { approximately equal to } 2.7183, \\
c_{1} \text { to } c_{n} \quad \text { are the regression model coefficients, and } \\
V_{1} \text { to } V_{n} \quad \begin{array}{l}
\text { are the explanatory variables (basin } \\
\text { characteristics). }
\end{array}
\end{gathered}
$$

A separate logistic regression equation was developed for each of the six low-flow frequency statistics for the southern region. The logistic equations estimate the probability of low-flow frequency statistics being zero at an ungaged site. A probability cutpoint is used in logistic regression analyses as a threshold between the two response categories of "flow" or "zero flow." The cutpoint probability used for this study is 0.5 . Therefore, probabilities computed from the equations for ungaged sites that are greater than or equal to 0.5 are predicted to have "zero flow" and probabilities less than 0.5 are predicted to have "flow." The predictive accuracy of the logistic regression equations was evaluated using the percentage of streamgages incorrectly estimated to have zero flow (misclassification percentage). Final logistic regression models were selected primarily on the basis of minimizing the misclassification percentage.

\section{Final Regression Equations}

Final regression equations developed for the northeast, northwest, and southern low-flow regions defined for Iowa are listed in tables 11-13, along with the number of streamgages included in each regression analysis and several performance metrics. StreamStats variable names are used for the response and explanatory variables in the final regression equations (tables 11-13); definitions of the variables and the units of measure are listed in tables 2 and 5 . Ten basin characteristics are used as explanatory variables in the final regression equations (table 14 at end of report); these include three morphometric characteristics (DRNAREA, DRNFREQ, and RSD), three hydrologic characteristics (BFI, TAU_ANN, and STREAM_VAR), and four pedologic characteristics (SOILASSURGO, SOILBSSURGO, SOILCSSURGO, and KSATSSUR). GIS software is required to measure the basin characteristics included as explanatory variables in the final regression equations. All explanatory variables included in the final regression equations were statistically significant at the 95-percent confidence level and were not correlated with other explanatory variables used in the same equation. The performance metrics in tables 11-13 indicate the predictive accuracy of the final regression equations. Because four types of regression were used to develop the final equations, performance metrics are reported differently for each type of regression.

For the 12 left-censored regression equations developed for estimating selected low-flow frequencies for the northeast and northwest regions, SEE (in percent) is reported. For the six GLS regression equations developed for estimating selected low-flow frequencies for the southern region, a pseudo- $\mathrm{R}^{2}$ (in percent), a standard error of model (SEM, in percent), and an average standard error of prediction (SEP, in percent) are reported. SEE is not appropriate for evaluating GLS regressions because of the unequal weighting given to the streamgages in GLS regression (Risley and others, 2008). The resulting unequally weighted GLS residuals produce inflated SEE values that are not comparable to SEE from the left-censored or WLS regression analyses. The pseudo- $\mathrm{R}^{2}$, or pseudo coefficient of determination, is a measure of the percentage of the variation explained by the basin characteristics (explanatory variables) included in the model. The pseudo- $\mathrm{R}^{2}$ value is calculated on the basis of the degrees of freedom in the regression. Griffis and Stedinger (2007) describe how the pseudo- $\mathrm{R}^{2}$ is more appropriate than the traditional $\mathrm{R}^{2}$ or adjusted $\mathrm{R}^{2}$ in measuring the true variation explained by the explanatory variables in the GLS model. SEM measures the error of the model itself and does not include sampling error. SEM is the square root of the GLS model error variance (MEV) (Tasker and Stedinger, 1989). SEP represents the sum of the model error and the sampling error. SEP is the square root of the GLS average variance of prediction (Tasker and Stedinger, 1989; Eng and others, 2009). For the three WLS regression equations developed for estimating QAH for each of the three regions, a SEP (in percent) and a RMSE (in percent) are reported. The SEP reported for the WLS regression equations is based on the mean-square error (MSE) of the residuals and is computed differently than the SEP reported for the GLS regression equations. For the six logistic regression equations developed for estimating selected low-flow frequencies for the southern region, a misclassification percentage is reported. The misclassification percentage is a measure of the percentage of streamgages in the logistic regression analysis that were incorrectly estimated to have zero flow.

The logistic regression equations developed for the southern region (table 13) should be used first to determine the probability of a specific low-flow frequency statistic equaling zero flow for an ungaged site in this region before the lowflow frequency statistic is estimated using the GLS regression equation. If the resulting probability $\left(P_{z e r o}\right)$ is greater or equal to 0.5 , then the value for that low-flow frequency statistic is estimated to be zero flow and the appropriate GLS regression equation should not be used. If the resulting probability is less than 0.5 , then the appropriate GLS regression equation should be used to estimate the value of the low-flow frequency statistic. For example, if the probability estimate $\left(P_{z e r o}\right)$ for M7D10Y from the logistic regression equation is 0.55 , the estimate for M7D10Y is zero flow; if the probability estimate $\left(P_{\text {zero }}\right)$ is 0.45 , an estimate for M7D10Y should be calculated from the appropriate GLS regression equation.

With the exception of SEP, the performance metrics indicate how well the equations perform on the streamgages used in the regression analyses. SEP is a measure of the accuracy that GLS and WLS regression models can predict low-flow 
Table 11. Regression equations for estimating selected low-flow frequency statistics and harmonic mean flows for unregulated streams in the northeast region of lowa.

[SEE, average standard error of estimate; RMSE, root mean square error; SEP, average standard error of prediction; M1D10Y, annual 1-day mean low flow for a recurrence interval of 10 years; DRNAREA, GIS drainage area; TAU_ANN, annual base-flow-recession time constant; KSATSSUR, average soil permeability; NA, not applicable; M7D10Y, annual 7-day mean low flow for a recurrence interval of 10 years; M30D10Y, annual 30-day mean low flow for a recurrence interval of 10 years; M30D5Y, annual 30-day mean low flow for a recurrence interval of 5 years; M1D10Y1012, seasonal (October through December) 1-day mean low flow for a recurrence interval of 10 years; M7D10Y1012, seasonal (October through December) 7-day mean low flow for a recurrence interval of 10 years; QAH, harmonic mean flow; STREAM_VAR, streamflow-variability index; DRNFREQ, drainage frequency]

\begin{tabular}{|c|c|c|c|}
\hline Statistic equation & $\begin{array}{c}\text { Number of } \\
\text { streamgages used to } \\
\text { develop equation }\end{array}$ & $\begin{array}{c}\text { SEE or RMSE } \\
\text { (percent) }\end{array}$ & $\begin{array}{c}\text { SEP } \\
\text { (percent) }\end{array}$ \\
\hline \multicolumn{4}{|l|}{ Left-censored regression equations } \\
\hline M1D10Y $=10^{-8.64}$ DRNAREA $^{1.22}$ TAU_ANN $^{3.69}$ KSATSSUR $^{1.01}$ & 43 & 80.6 & NA \\
\hline M7D10Y $=10^{-8.56}$ DRNAREA $^{1.23}$ TAU_ANN $^{3.63} \mathrm{KSATSSUR}^{1.04}$ & 43 & 84.6 & NA \\
\hline M30D10Y $=10^{-8.26}$ DRNAREA $^{1.23}$ TAU_ANN $^{3.48}$ KSATSSUR $^{1.03}$ & 43 & 88.1 & NA \\
\hline M30D5Y $=10^{-6.48}$ DRNAREA $^{1.16}$ TAU_ANN $^{2.75}$ KSATSSUR $^{0.727}$ & 43 & 64.7 & NA \\
\hline M1D10Y1012 $=10^{-7.93}$ DRNAREA $^{1.16}$ TAU_ANN $^{3.33}$ KSATSSUR $^{1.08}$ & 44 & 72.3 & NA \\
\hline M7D10Y1012 $=10^{-7.57}$ DRNAREA $^{1.16}$ TAU_ANN $^{3.17} \mathrm{KSATSSUR}^{1.05}$ & 44 & 66.5 & NA \\
\hline \multicolumn{4}{|l|}{ Weighted least-squares regression equation } \\
\hline $\mathrm{QAH}=10^{-1.83} \mathrm{DRNAREA}^{1.21} \mathrm{STREAM}_{\mathrm{VAR}}{ }^{-1.52} \mathrm{DRNFREQ}^{0.843}$ & 44 & 63.7 & $66.4 *$ \\
\hline
\end{tabular}

${ }^{*}$ Based on mean-square error residuals.

Table 12. Regression equations for estimating selected low-flow frequency statistics and harmonic mean flows for unregulated streams in the northwest region of lowa.

[SEE, average standard error of estimate; RMSE, root mean square error; SEP, average standard error of prediction; M1D10Y, annual 1-day mean low flow for a recurrence interval of 10 years; DRNAREA, GIS drainage area; BFI, base-flow index; SOILASSURGO, hydrologic soil type A; NA, not applicable; M7D10Y, annual 7-day mean low flow for a recurrence interval of 10 years; M30D10Y, annual 30-day mean low flow for a recurrence interval of 10 years; M30D5Y, annual 30-day mean low flow for a recurrence interval of 5 years; M1D10Y1012, seasonal (October through December) 1-day mean low flow for a recurrence interval of 10 years; M7D10Y1012, seasonal (October through December) 7-day mean low flow for a recurrence interval of 10 years; QAH, harmonic mean flow; TAU_ANN, annual base-flow-recession time constant; RSD, relative stream density]

\begin{tabular}{|c|c|c|c|}
\hline Statistic equation & $\begin{array}{c}\text { Number of } \\
\text { streamgages used to } \\
\text { develop equation }\end{array}$ & $\begin{array}{l}\text { SEE or RMSE } \\
\text { (percent) }\end{array}$ & $\begin{array}{c}\text { SEP } \\
\text { (percent) }\end{array}$ \\
\hline \multicolumn{4}{|l|}{ Left-censored regression equations } \\
\hline M1D10Y $=10^{-9.88} 10^{1.97(\text { DRNAREA })^{0.15}} 10^{14.5(\mathrm{BFI})^{2}} 10^{0.135(\text { SOILASSURGO) }}$ & 37 & 104.8 & NA \\
\hline M7D10Y $=10^{-9.35} 10^{1.92(\text { DRNAREA })^{0.15}} 10^{13.5(\mathrm{BFI})^{2}} 10^{0.134(\text { SOILASSURGO) }}$ & 37 & 111.8 & NA \\
\hline $\mathrm{M} 30 \mathrm{D} 10 \mathrm{Y}=10^{-5.55} 10^{1.69(\mathrm{DRNAREA})^{0.15}} 10^{7.72(\mathrm{BFI})^{3}} 10^{0.113(\text { SOILASSURGO) }}$ & 37 & 109.7 & NA \\
\hline M30D5Y $=10^{-4.87} 10^{1.55(\text { DRNAREA })^{0.15}} 10^{4.47(\mathrm{BFI})^{2}} 10^{0.090(\text { SOILASSURGO) }}$ & 37 & 87.2 & NA \\
\hline M1D10Y1012 $=10^{-6.07} 10^{1.61(\text { DRNAREA })^{0.15}} 10^{6.78(\mathrm{BFI})^{2}} 10^{0.108(\text { SOILASSURGO) }}$ & 38 & 85.8 & NA \\
\hline M7D10Y1012 $=10^{-5.76} 10^{1.60(\text { DRNAREA })^{0.15}} 10^{6.25(\mathrm{BFI})^{2}} 10^{0.102 \text { (SOILASSURGO) }}$ & 38 & 88.4 & NA \\
\hline \multicolumn{4}{|l|}{ Weighted least-squares regression equation } \\
\hline $\mathrm{QAH}=10^{-5.87} \mathrm{DRNAREA}{ }^{1.39} 10^{0.088\left(\mathrm{TAU} \_\mathrm{ANN}\right)} 10^{3.07(\mathrm{RSD})}$ & 38 & 71.6 & $75.1 *$ \\
\hline
\end{tabular}

*Based on mean-square error residuals. 


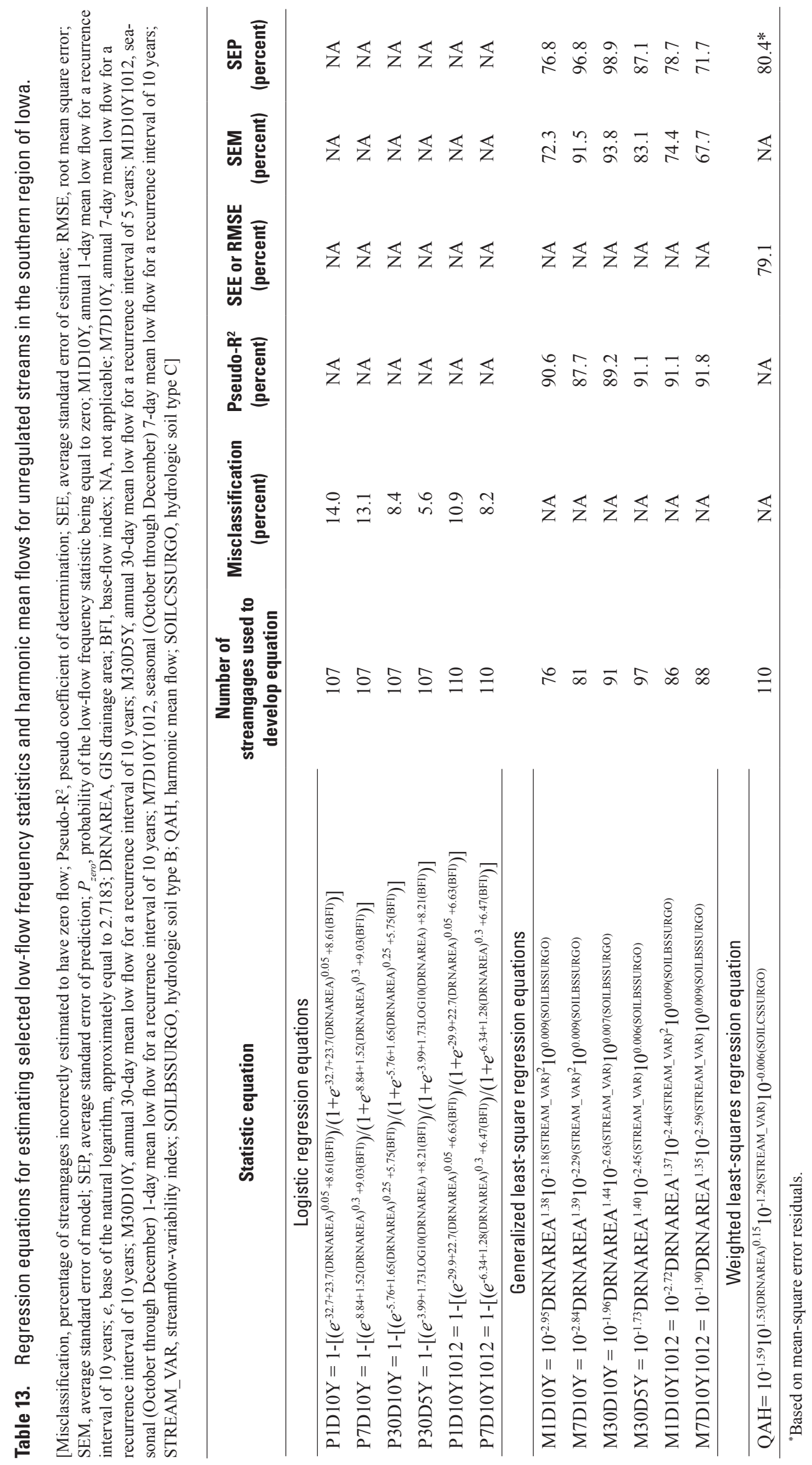


frequency and harmonic-mean-flow statistic values at ungaged sites. The same explanatory variables were used to develop all low-flow frequency equations for each region to minimize the possibility of predictive inconsistencies between estimates of different low-flow frequency statistics, so that estimates will decrease with decreasing n-days and increasing recurrence interval. For example, maintaining the same regression-model form (same explanatory variables) helps to maximize the probability an estimate for M1D10Y is less than an estimate for M7D10Y, an estimate for M7D10Y is less than an estimate for M30D10Y, and an estimate for M30D10Y is less than an estimate for M30D5Y.

Output from the WREG program (Eng and others, 2009) for GLS and WLS regression models identifies streamgages that are possible outliers in the data set as plotted points or tabulated values that exceed a leverage threshold value or an influence threshold value. Leverage points (Eng and others, 2009) are outliers that may unduly influence the estimation of regression constants and are a measure of how large or small explanatory variables (basin characteristics) are for a specific streamgage as compared to the centroid of values of the same explanatory variables at all other streamgages. Influence points are measured by Cook's D statistic (Cook, 1977; Helsel and Hirsch, 2002), and these are outliers that have unduly influenced the estimation of regression constants. The WREG program also was used to develop preliminary GLS regression equations for selected low-flow frequency statistics for the northeast and northwest regions; these equations were not published because of the use of the left-censored regression analyses. Streamgages identified as outliers for the GLS or WLS regression models were noted for each low-flow frequency and harmonic-mean-flow statistic for each low-flow region. As previously noted in an earlier section Definition of Low-Flow Regions, 14 streamgages identified by the WREG program as outliers were removed from the regression data sets (table 9) because of a documented or suspected alteration in the watershed that may affect low-flow conditions.

\section{Accuracy and Limitations of Regression Equations}

The regional regression equations developed in this study apply only to stream sites in Iowa where low flows are not significantly affected by regulation, diversion, or urbanization. The applicability and accuracy of the regional equations depend on whether the basin characteristics measured for an ungaged stream site are within the range of the characteristic values used to develop the regression equations. The acceptable range of basin characteristic values used to develop each regional regression equation (tables 11-13) are tabulated as minimum and maximum values in table 14 (at end of report). The applicability of the regional equations is unknown when any characteristic value measured for an ungaged site is outside the acceptable range. In addition, basin-characteristic measurements at ungaged sites should be computed using the same GIS data sets and measurement methods used in this study; the USGS StreamStats Web-based GIS tool includes the same GIS data layers and measurement methods as used to develop the regression equations in this study.

The frequency regression equations presented in this report should be used with caution for ungaged stream sites with basin-characteristic values approaching the minimum or maximum limits (table 14) because inconsistencies in the estimates may result. Two types of inconsistencies in estimates may result for ungaged sites: (1) for the same recurrence interval, the discharge estimate for a smaller number of consecutive days may be greater than the discharge estimate for a larger number of consecutive days, for example, a M7D10Y discharge may be estimated to be greater than a M30D10Y discharge; and (2) for different recurrence intervals, the discharge estimate for a larger recurrence interval may be greater than the discharge estimate for a smaller recurrence interval, for example, a M30D10Y estimate may be greater than a M30D5Y estimate. Inconsistencies in estimates occurred for four of the streamgages listed in table 2, because some of their basin-characteristic values (table 3 ) are at or near the minimum or maximum limits listed in table 14. For the northwest region, the predicted discharge for M7D10Y exceeds or equals the predicted discharge for M30D10Y for streamgages 06478518 (map number 136), 06600000 (map number 143), and 06606600 (map number 153); and for the northeast region, the predicted discharge for M30D10Y exceeds the predicted discharge for M30D5Y for streamgage 05410490 (map number 13). Different regression models were tested for the northwest region to minimize the occurrence of inconsistencies in estimates. Although an attempt was made to reduce the occurrence of inconsistencies in estimates by using the same explanatory variables for each regional set of low-flow frequency equations, the possibility exists that inconsistencies in estimates may occur. Inconsistencies in estimates may occur because regional regression equations were developed separately and have variable prediction intervals depending on the size and variability of the datasets used to develop the regression equations. If inconsistencies in estimates are obtained for an ungaged stream site, a comparison of all low-flow frequency estimates for the site and a check of streamgage data or other published data may help to determine which low-flow frequency statistic is inconsistent.

Although reported SEE and SEP performance metrics are not directly comparable between the regional equations, in general, predictive accuracies tend to be the best for the northeast region, second best for the southern region, and poorest for the northwest region. For the selected low-flow frequency equations, SEE for the northeast region ranges from 64.7 to 88.1 percent, SEP for the southern region ranges from 71.7 to 98.9 percent, and SEE for the northwest region ranges from 85.8 to 111.8 percent. SEP for the regional QAH equations were 66.4 (northeast), 75.1 (northwest), and 80.4 percent (southern). The percentage of variation in the response variables explained by the explanatory variables (pseudo- $\mathrm{R}^{2}$ ) for the selected low-flow frequency equations developed for 
the southern region ranges from 87.7 to 91.8 percent. Misclassification (the percentage of streamgages incorrectly estimated to have zero flow for the logistic equations developed for the southern region) ranges from 5.6 to 14.0 percent. Of the six low-flow frequency equations developed for each region, the M7D10Y1012, M1D10Y1012, and M30D5Y regression equations generally have the best predictive accuracy and the M30D10Y and M7D10Y equations generally have the poorest accuracy. The generally better predictive accuracies obtained for the seasonal equations (October to December), as compared to the annual equations, indicate less variation in base flows during the fall when compared to the entire climatic year.

The natural variability of streamflow may be an important factor associated with the predictive accuracy of low-flow frequency and harmonic-mean-flow regression equations. Estimation of streamflow statistics that have greater variability will have poorer predictive accuracies than estimation of statistics with less variability. Streamflow variability, as mapped for kriged STREAM_VAR values (fig. 7), generally is lower for the northeast region, compared to the other two regions, and overall predictive accuracies are best for estimating selected low-flow frequency statistics and harmonic mean flows in the northeast region.

The regression equations presented in this report also should be used with caution in areas where low flows are affected by significant gains as a result of large springs or significant losses as a result of sinkholes common to karst topography in areas underlain by limestone. The Paleozoic Plateau landform region, within the northeast low-flow region (fig. 3), contains karst areas where low flows may vary considerably spatially because of gaining or losing stream reaches. User judgment may be required to decide if an ungaged site in a karst area may be affected by significant gains or losses in low flow, and low-flow frequency and harmonic-mean-flow regression estimates should be compared against streamgage data or other published data. The regression equations also should be used with caution for streams within the Mississippi River and Missouri River Alluvial Plains landform regions (fig. 3) because streamgage data representing these landform regions were not included in the development of the regression equations. If the equations are used at ungaged sites on regulated streams, or on streams affected by water-supply and agricultural withdrawals, then the estimates will need to be adjusted by the amount of regulation or withdrawal to estimate the actual flow conditions if that is of interest.

Because of the uncertainty in measuring and estimating flows below $0.1 \mathrm{ft}^{3} / \mathrm{s}$, the censoring threshold used to develop the left-censored regression equations for the northeast and northwest regions was set at $0.1 \mathrm{ft}^{3} / \mathrm{s}$. Thus, selected low-flow frequency estimates calculated from left-censored regression equations that are $0.1 \mathrm{ft}^{3} / \mathrm{s}$, or lower, should be reported as less than $0.1 \mathrm{ft}^{3} / \mathrm{s}$. For the southern region, selected low-flow frequency estimates calculated from GLS regression equations that are lower than $0.1 \mathrm{ft}^{3} / \mathrm{s}$ also should be reported as less than $0.1 \mathrm{ft}^{3} / \mathrm{s}$ to maintain a consistent prediction-discharge-reporting limit for Iowa. Likewise, QAH estimates calculated from WLS regression equations that are lower than $0.1 \mathrm{ft}^{3} / \mathrm{s}$ also should be reported as less than $0.1 \mathrm{ft}^{3} / \mathrm{s}$. Because the precision of response- and explanatory-variable data used to develop the equations was often limited to three significant figures, selected-statistic discharges estimated from the regression equations also should be limited to three significant figures.

Figure 11 shows the relation between observed and predicted discharges for M7D10Y for each of the three low-flow regions. The uncertainty of regression estimates can be seen graphically as a greater scatter of observed in relation to predicted points along the 1:1 line. A greater uncertainty is evident for M7D10Y discharges below the prediction-dischargereporting limit of $0.1 \mathrm{ft}^{3} / \mathrm{s}$. The point shown on figure 11 for the northeast region as map number 17 is the streamgage 05412100 Roberts Creek above Saint Olaf, Iowa (fig. 1). The Roberts Creek Basin is within a karst area of northeastern Iowa (Rowden and others, 1995) and as shown on figure 11 and listed in table 2, the predicted M7D10Y discharge for this streamgage is significantly greater than the observed M7D10Y discharge, indicating the possibility of a losing stream reach upstream from the site.

\section{Prediction Intervals}

Although regression equations presented in tables 11-13 can be used to estimate selected low-flow frequency statistics and harmonic mean flows, the true values of the selected low-flow frequency statistics and harmonic mean flows are unknown. A measure of the uncertainty associated with the regression estimate of a low-flow frequency or harmonicmean-flow statistic is the prediction interval. The interval is the estimated value plus or minus a given margin of error. A prediction interval is the probability that the actual value of the estimated low-flow frequency or harmonic-mean-flow statistic will be within this margin of error (Helsel and Hirsch, 2002). The prediction interval determines the range of discharge values predicted for selected statistics given a confidence level and the SEP or SEE. For a 90-percent prediction interval, the true low-flow frequency or harmonic-mean-flow statistic has a 90-percent probability of being within the margin of error. The USGS StreamStats Web-based GIS tool (http://water.usgs. gov/osw/streamstats/index.html) uses the 90-percent prediction interval estimates as part of the computation of lowflow frequency and harmonic-mean-flow statistic estimates for ungaged stream sites. The following equation, modified from Tasker and Driver (1988), can be used to compute the 90-percent prediction interval for the true value of a low-flow frequency or harmonic-mean-flow statistic for an ungaged site: 

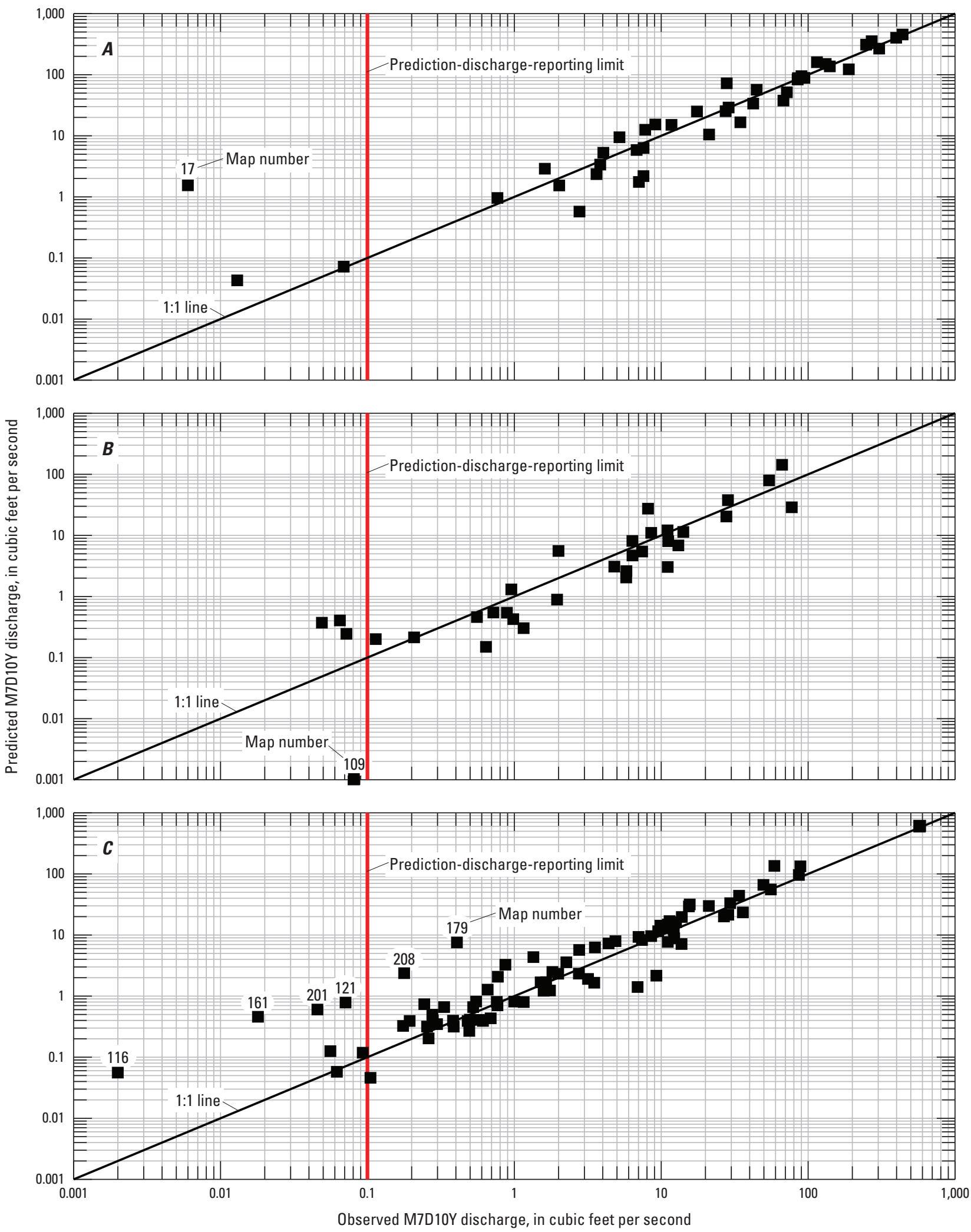

Figure 11. Relation between the annual 7-day mean low flow for a recurrence interval of 10 years (M7D10Y) discharges computed from observed streamflow and those predicted from regression equations for low-flow regions in lowa. $A$, Northeast region. $B$, Northwest region. $C$, Southern region. 


$$
\frac{Q}{T}<Q<Q T
$$

where

$Q \quad$ is the low-flow frequency or harmonic-meanflow discharge predicted for the ungaged site from the regression equation, and $T$ is computed as:

$$
T=10^{\left[t_{(a / 2, n-p)} S_{i}\right]}
$$

where

$$
\begin{gathered}
t_{(\alpha 2, n-p)} \quad \text { is the critical value from the student's } \\
t \text {-distribution at alpha level } \alpha(\alpha=0.10 \text { for } \\
\text { 90-percent prediction intervals, critical } \\
\text { values may be obtained in many statistics } \\
\text { textbooks, Iman and Conover (1983), or } \\
\text { from the World-Wide Web; } \\
\text { is the degrees of freedom with } n \text { streamgages } \\
\text { included in the regression analysis and } p \\
\text { parameters in the equation (the number of } \\
\text { explanatory variables plus one); and } \\
\text { is the standard error of prediction for site } i, \\
\text { and is computed as: } \\
S_{i}=\left[M E V+X_{i} U X_{i}^{\prime}\right]^{0.5}
\end{gathered}
$$

where

$$
M E V \quad \text { is the model error variance from GLS }
$$
regression or the MSE from left-censored regression or from WLS regression equations developed in this study using a user-defined weighting matrix;

$X_{i} \quad$ is the row vector for the streamgage $i$, starting with the number 1 , followed by the logarithmic values of the basin characteristics used in the regression;

$U \quad$ is the covariance matrix for the annual or seasonal regression coefficients; and

$X_{i}^{\prime} \quad$ is the matrix algebra transpose of $X_{i}$ (Ludwig and Tasker, 1993; Ries and Friesz, 2000).

Similar to the SEP, $S_{i}$ represents the sum of the model error and the sampling error for a single site $i$. The $X_{i} U X_{i}^{\prime}$, term in equation 12 also is referred to as the sampling error variance. The values of $t_{(\alpha / 2, n-p)}$ and $U$ needed to determine prediction intervals for estimates obtained by the regression equations in tables 11-13 are presented in table 15 (at end of report).

\section{Application of Regression Equations}

Methods for applying the regional regression equations listed in tables 11-13 are described in the following examples:

\section{Example 1}

This example is a calculation of M7D10Y (annual 7-day mean low flow for a recurrence interval of 10 years) for a stream site in the southern region. Figure 1 shows the location of the streamgage 06903700 South Fork Chariton River near Promise City, Iowa, as map number 207. This watershed is located entirely with the southern region. Estimating selected low-flow frequency statistics for the southern region is a one- or two-step process. The first step is to estimate the probability of zero flow using the logistic regression equations listed in table 13. The logistic regression equations are only used to estimate the probability of zero flow for frequency statistics for stream sites in the southern region. Using the USGS StreamStats Web-based GIS tool, DRNAREA (drainage area) is measured as $169.52 \mathrm{mi}^{2}$ and BFI (base-flow index) is measured as 0.192 (table 3). Because both basin-characteristic values are within the range of values listed in table 14 , the logistic regression equation is applicable for estimating the probability of zero flow for M7D10Y. The M7D10Y logistic regression equation from table 13 is

$$
\begin{gathered}
\text { P7D10Y }=1-\left[\left(e^{-8.84+1.52(\text { DRNAREA })^{0.3}+9.03(\mathrm{BFI})}\right) /\left(1+e^{-8.84+1.52(\text { DRNAREA })^{0.3}+9.03(\mathrm{BFI})}\right)\right] \\
\text { P7D10Y }=1-\left[\left(e^{-8.84+1.52(169.52)^{0.3}+9.03(0.192)}\right) /\left(1+e^{-8.84+1.52(169.52)^{0.3}+9.03(0.192)}\right)\right] \\
\text { P7D10Y }=1-\left[\left(e^{-0.0168}\right) /\left(1+e^{-0.0168}\right)\right] \\
\text { P7D10Y }=0.504
\end{gathered}
$$

Because the estimate for P7D10Y is greater than the cutpoint-probability threshold of 0.5 used for this study, the estimate for M7D10Y is zero flow. 


\section{Example 2}

This example is a calculation of M30D10Y (annual 30-day mean low flow for a recurrence interval of 10 years) for the same stream site (map number 207, fig. 1) in the southern region as illustrated in example 1. Again, the first step is to estimate the probability of zero flow. The M30D10Y logistic regression equation from table 13 is

$$
\begin{aligned}
& \text { P30D10Y }=1-\left[\left(e^{-5.76+1.65 \text { (DRNAREA })^{0.25}+5.75(\mathrm{BFI})}\right) /\left(1+e^{-5.76+1.65 \text { (DRNAREA) }^{0.25}+5.75(\mathrm{BFI})}\right)\right] \\
& \text { P30D10Y }=1-\left[\left(e^{-5.76+1.65(169.52)^{0.25}+5.75(0.192)}\right) /\left(1+e^{-5.76+1.65(169.52)^{0.25}+5.75(0.192)}\right)\right] \\
& \mathrm{P} 30 \mathrm{D} 10 \mathrm{Y}=1-\left[\left(e^{1.2977}\right) /\left(1+e^{1.2977}\right)\right] \\
& \mathrm{P} 30 \mathrm{D} 10 \mathrm{Y}=0.215
\end{aligned}
$$

Because the estimate for P30D10Y is less than the cutpoint-probability threshold of 0.5 used for this study, the flow is estimated to be greater than zero for M30D10Y. Therefore, the second step is to estimate the amount of flow for M30D10Y using the GLS regression equation listed in table 13. Using StreamStats, STREAM_VAR (streamflow-Variability index) is measured as 0.760 and SOILBSSURGO (hydrologic soil type B) is measured as 17.984 percent (table 3 ). Because all three basin characteristic values are within the range of values listed in table 14, the GLS regression equation is applicable for estimating M30D10Y. The M30D10Y GLS regression equation from table 13 is:

$$
\begin{gathered}
\text { M30D10Y }=10^{-1.96} \text { DRNAREA }^{1.44} 10^{-2.63(\text { STREAM_VAR })} 10^{0.007(\text { SOILBSSURGO) }} \\
\text { M30D10Y }=10^{-1.96}(169.52)^{1.44} 10^{-2.63(0.760)} 10^{0.007(17.984)} \\
\text { M30D10Y }=0.24 \mathrm{ft}^{3} / \mathrm{s}
\end{gathered}
$$

To calculate a 90 -percent prediction interval for this M30D10Y estimate using equation 10, the $X_{i}$ vector is

$$
X_{i}=\{1, \log 10(169.52), 0.760,17.984\},
$$

the model error variance $(\mathrm{MEV})$ from table 15 is 0.119068 , and the covariance matrix $(U)$ is:

\begin{tabular}{r|crrr}
\hline & Intercept & \multicolumn{1}{c}{ DRNAREA } & STREAM_VAR & SOILBSSURGO \\
\cline { 2 - 5 } Intercept & 0.173419660 & -0.012204313 & -0.175826400 & -0.000491100 \\
DRNAREA & -.012204313 & .005005351 & -.002544634 & .000005606 \\
STREAM_VAR & -.175826400 & -.002544634 & .254156970 & .000480857 \\
SOILBSSURG0 & -.000491100 & .000005606 & .000480857 & .000002804 \\
\hline
\end{tabular}

Using matrix algebra, the product of $X_{i} U X_{i}^{\prime}$ is determined in two steps: (1) by multiplying $X_{i}^{\prime}$ (the transpose of $X_{i}$ ) by the covariance matrix, $\mathrm{U}$, to obtain $U X_{i}^{\prime}$, and (2) by multiplying $U X_{i}^{\prime}$ by $X_{i}$. In this example, the value of $X_{i} U X_{i}^{\prime}$ is 0.011641 .

The standard error of prediction for this site as computed from equation 12 is

$$
S_{i}=[0.119068+0.011641]^{0.5}=0.361537
$$

and $\mathrm{T}$ from equation 11 is

$$
T=10^{(1.6626)(0.361537)}=3.9911,
$$

where the critical value $\left(t_{(\alpha / 2, n-p)}\right)$ from the student's $t$-distribution for the 90-percent prediction interval is 1.6626 (table 15).

The 90-percent prediction interval is estimated from equation 10 as

$$
\begin{gathered}
0.24 / 3.9911<\mathrm{M} 30 \mathrm{D} 10 \mathrm{Y}<(0.24)(3.9911), \text { or, } \\
0.06<\mathrm{M} 30 \mathrm{D} 10 \mathrm{Y}<0.96 .
\end{gathered}
$$

Because the lower end of the prediction interval is below the prediction-discharge-reporting limit of $0.1 \mathrm{ft}^{3} / \mathrm{s}$ established for this study, the 90-percent prediction interval estimate is

$$
<0.1 \mathrm{ft}^{3} / \mathrm{s}<\mathrm{M} 30 \mathrm{D} 10 \mathrm{Y}<0.96 \mathrm{ft}^{3} / \mathrm{s} .
$$




\section{Example 3}

This example is a calculation of M1D10Y (annual 1-day mean low flow for a recurrence interval of 10 years) for a stream site in the northeast region. Figure 1 shows the location of the streamgage 05420560 Wapsipinicon River near Elma, Iowa, as map number 26. This watershed is located entirely within the northeast low-flow region. Using StreamStats, DRNAREA (drainage area) is measured as $96.44 \mathrm{mi}^{2}$, TAU_ANN (annual base-flow-recession time constant) is measured as 29.732 days, and KSATSSUR (average soil permeability or hydraulic conductivity of the soil) is measured as $17.800 \mu \mathrm{m} / \mathrm{s}$ (table 3). Because all three basin-characteristic values are within the range of values listed in table 14, the left-censored regression equation is applicable for estimating M1D10Y. The M1D10Y left-censored regression equation from table 11 is

$$
\begin{gathered}
\text { M1D10Y }=10^{-8.64} \text { DRNAREA }^{1.22} \text { TAU_ANN }{ }^{3.69} \mathrm{KSATSSUR}^{1.01} \\
\text { M1D10Y }=10^{-8.64}(96.44)^{1.22}(29.732)^{3.69}(17.800)^{1.01} \\
\text { M1D10Y }=3.02 \mathrm{ft}^{3} / \mathrm{s}
\end{gathered}
$$

To calculate a 90-percent prediction interval for this M1D10Y estimate using equation 10, the $X_{i}$ vector is

$$
X_{i}=\{1, \log 10(96.44), \log 10(29.732), \log 10(17.800)\},
$$

the model error variance $(\mathrm{MEV})$ from table 15 is 0.094433 , and the covariance matrix $(U)$ is:

\begin{tabular}{r|rrrr}
\hline \multicolumn{1}{c}{} & \multicolumn{1}{c}{ Intercept } & \multicolumn{1}{c}{ DRNAREA } & \multicolumn{1}{c}{ TAU_ANN } & \multicolumn{1}{c}{ KSATSSUR } \\
\cline { 2 - 5 } Intercept & 7.599114317 & -0.017291210 & -3.340946820 & -2.069765708 \\
DRNAREA & -.017291210 & .076139961 & .034377290 & -.190210256 \\
TAU_ANN & -3.340946818 & .034377288 & 1.893205880 & .313756238 \\
KSATSSUR & -2.069765708 & -.190210256 & .313756240 & 1.751366356 \\
\hline
\end{tabular}

Using matrix algebra, the product of $X_{i} U X_{i}^{\prime}$ is determined in two steps: (1) by multiplying $X_{i}^{\prime}$ (the transpose of $X_{i}$ ) by the covariance matrix, $\mathrm{U}$, to obtain $U X_{i}^{\prime}$, and (2) by multiplying $U X_{i}^{\prime}$ by $X_{i}$. In this example, the value of $X_{i} U X_{i}^{\prime}$ is 0.070618 .

The standard error of prediction for this site as computed from equation 12 is

and $T$ from equation 11 is

$$
S_{i}=[0.094433+0.070618]^{0.5}=0.406265
$$

$$
T=10^{(1.6849)(0.406265)}=4.8363,
$$

where the critical value $\left(t_{(\alpha / 2, n-p)}\right)$ from the student's $t$-distribution for the 90 -percent prediction interval is 1.6849 (table 15).

The 90-percent prediction interval is estimated from equation 10 as

$$
\begin{gathered}
3.02 / 4.8363<\mathrm{M} 1 \mathrm{D} 10 \mathrm{Y}<(3.02)(4.8363), \text { or, } \\
0.62 \mathrm{ft}^{3} / \mathrm{s}<\mathrm{M} 1 \mathrm{D} 10 \mathrm{Y}<14.6 \mathrm{ft}^{3} / \mathrm{s}
\end{gathered}
$$




\section{Region-of-Influence Method to Estimate Selected Low-Flow Frequency Statistics and Harmonic Mean Flows for Ungaged Stream Sites}

The region-of-influence (RoI) method has been used to estimate flood-frequency discharges at ungaged sites by relating basin characteristics to flood-frequency discharges for a unique subset of streamgages (Burn, 1990; Eng and others, 2005, 2007). The RoI method also is applicable for the estimation of low-flow frequency statistics and harmonic mean flows. The RoI method was tested as part of this study using WREG (Eng and others, 2009) to determine whether predictive accuracies for selected low-flow frequency statistics and harmonic mean flows may be improved using RoI compared to traditional regional regression. The RoI method defines a unique subset, or region of influence, for each ungaged site determined by selecting streamgages with basin characteristics similar to those measured for the ungaged site. The RoI is defined as the N "nearest" streamgages to the ungaged site, where "nearest" is measured by similarity of basin characteristics in Euclidean space. An advantage of this method is extrapolation errors tend to be small because the predictions naturally occur near the center of the space of the basin characteristics.

To investigate the RoI method for this study, basin characteristics identified as the most significant in the statewide OLS regression analyses were selected and compiled into a RoI data set that included the same number of streamgages as used for the development of statewide regression equations (table 8). The RoI method in WREG allows three approaches for defining hydrologic similarity among streamgage basins: independent or predictor-variable space RoI (PRoI), geographic space RoI (GRoI), and a combination of predictorvariable and geographic spaces called hybrid RoI (HRoI). Preliminary RoI analyses were performed to determine the best combination of three input parameters required by the RoI program in WREG: (1) the best set of basin characteristics must be selected for use as explanatory variables, (2) the number of streamgages $(\mathrm{N})$ must be selected to compose the specific region of influence for the statewide study area, and (3) the PRoI, GRoI, or HRoI RoI approach must be selected.

RMSEs were evaluated for the preliminary RoI analyses to determine the best combination of the three required input parameters for WREG. Table 16 lists the best combinations of explanatory variables with the lowest RMSEs that were identified statewide, and by low-flow regions, for each of the seven selected statistics through iterative RoI analyses using WREG. Although statewide and regional RMSE and SEP performance metrics are not directly comparable, overall, RMSEs for RoI were poorer than SEPs for statewide GLS regression equations (table 8) and were poorer than SEEs or SEPs for regional regression equations (tables 11-13). Because regional regression equations provided improved predictive accuracies, the
RoI method was not developed further and RoI equations are not listed in this report but are summarized in table 16 to provide a reference for showing the improvement obtained using regional regression equations.

\section{Weighted Drainage-Area Ratio Method to Estimate Selected Low-Flow Frequency Statistics and Harmonic Mean Flows for Ungaged Sites on Gaged Streams}

Two drainage-area ratio methods were tested in this study to determine the preferred method to use for ungaged sites on gaged streams in Iowa and to determine the appropriate range of drainage-area ratios between a streamgage and an ungaged stream site. A simple drainage-area ratio (DAR) method was tested alongside a weighted drainage-area ratio (WDAR) method, hereafter these methods are referred to as DAR and WDAR. A gaged stream is a stream with a streamgage for which low-flow frequency or harmonic-mean-flow statistics have been computed.

The DAR method is based on the assumption that streamflow at an ungaged site is the same per unit area as that for a streamgage located upstream or downstream from the ungaged site. Low-flow frequency or harmonic-mean-flow statistics calculated for the streamgage are multiplied by the DAR of the ungaged site and the streamgage to estimate low-flow frequency or harmonic-mean-flow statistics at the ungaged site. The accuracy of the DAR method depends on similarities in drainage area and other basin characteristics (such as soils, geology, precipitation) between the two sites. The DAR method calculation is:

$$
Q_{D A R u}=\left[\frac{D A_{u}}{D A_{g}}\right] Q_{o g}
$$

where

$$
\begin{array}{cl}
Q_{D A R u} & \begin{array}{l}
\text { is the DAR low-flow frequency or harmonic- } \\
\text { mean-flow estimate of the ungaged site, }
\end{array} \\
D A_{u} & \text { is the drainage area of the ungaged site, } \\
D A_{g} & \text { is the drainage area of the streamgage, and } \\
Q_{o g} & \begin{array}{l}
\text { is the low-flow frequency or harmonic-mean- } \\
\text { flow estimate computed from the observed } \\
\text { streamgage record. }
\end{array}
\end{array}
$$

The DAR method typically is applied when an ungaged site is on the same stream as a streamgage and the DAR of the two sites is between 0.5 and 1.5 (Hortness, 2006). Some studies have tested DARs to determine the range for which the DAR method provides estimates of low-flow statistics that are better than estimates obtained using regional regression equations (RRE). In Ohio, Koltun and Schwartz (1986) 


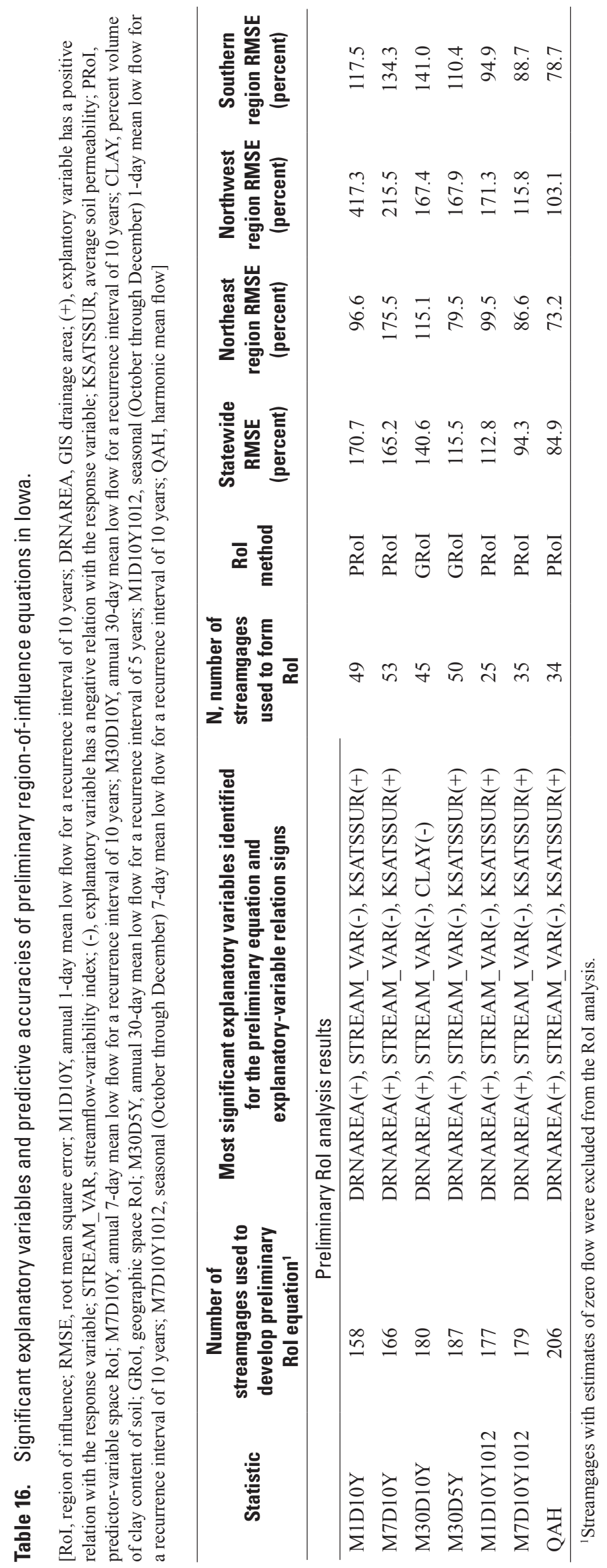


recommended a DAR range between 0.85 and 1.15 for estimating low-flow statistics; in Massachusetts, Ries and Friesz (2000) determined that a range of 0.3 to 1.5 was applicable for low-flow statistics.

The WDAR method applies an adjustment or weight to the RRE predicted estimate for the ungaged site on the basis of the difference between the observed and the RRE predicted estimates for the streamgage and on the basis of the difference in drainage areas between the two sites (Martin and Arihood, 2010; Eash, 2001). The WDAR method calculation is:

$$
Q_{W D A R u}=Q_{r u}\left[R-\left(\frac{2(|\Delta D A|)(R-1)}{D A_{g}}\right)\right]
$$

where

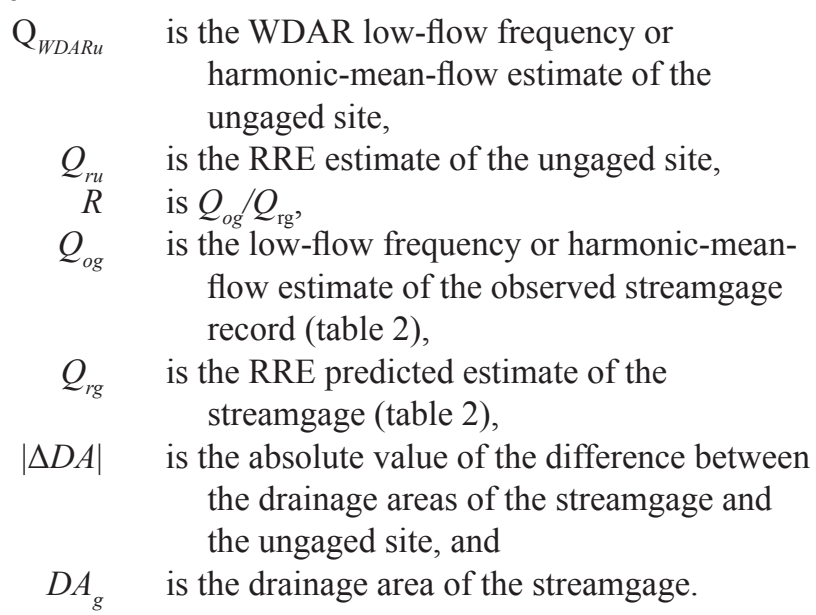

As the ratio of the estimate computed from the observed streamflow $\left(Q_{o g}\right)$ to the RRE predicted estimate $\left(Q_{r g}\right)$ approaches one for the streamgage, or as the difference in drainage area between the two sites approaches 50 percent, the value of the weighting term shown in brackets on the right side of equation 14 approaches one and it no longer has an effect on the RRE estimate for the ungaged site $\left(Q_{r u}\right)$.

To determine which method, DAR or WDAR, is preferred for Iowa and to determine the appropriate range of DARs for applying either method, 31 pairs of streamgages were selected for testing estimates of the M7D10Y statistic (table 17 at end of report) following an experiment design described by Ries and Friesz (2000). A set totaling 48 streamgages comprise the 31 pairs of streamgages. Each pair of streamgages is located on the same stream. Fourteen streamgages were tested twice because 13 of the 14 are paired with a streamgage located upstream and a streamgage located downstream, and 1 of the 14 was paired with streamgages located on two upstream forks. The set of 48 streamgages is located on 17 different streams in Iowa, and the set is located within all the landform regions of the State with the exception of the Mississippi and Missouri River Alluvial Plains (figs. 1 and 3). The period of record used to compute the M7D10Y statistic for each streamgage ranged between 11 to 52 years, with the mean and median number of years of record equal to 38.1 and 41.0, respectively. Drainage area sizes for the 48 streamgages range from about 61 to $7,783 \mathrm{mi}^{2}$, with mean and median drainage area sizes of 1,760 and 1,371 $\mathrm{mi}^{2}$, respectively (table 17). For the 31 pairs of streamgages, 9 pairs are located entirely within the northeast region with drainage area sizes ranging from 96 to $6,506 \mathrm{mi}^{2}, 11$ pairs are located primarily within the northwest region with drainage area sizes ranging from 227 to $3,425 \mathrm{mi}^{2}$, and 11 pairs are located primarily within the southern region with drainage area sizes ranging from 61 to $7,783 \mathrm{mi}^{2}$ (tables 2 and 17).

Thirty-one pairs of M7D10Y estimates were calculated for both the DAR and WDAR methods in which each of the paired streamgages was alternately assumed to be an ungaged site with the other paired site used as the streamgage. Absolute differences, in percent, between the estimates computed from the observed streamflow and the DAR, WDAR, and RRE estimates were determined for the M7D10Y statistic for each streamgage assumed to be an ungaged site (table 17). Figure 12 shows the absolute differences, in percent, from the estimates computed from observed streamflow and the DAR, WDAR, and RRE estimates plotted against the DAR of the assumed ungaged site and the streamgage. Smoothed curves are plotted through each data set to indicate the range of ratios in which the DAR or WDAR estimates may provide better results than the RRE estimates. The smoothed curves were obtained using a LOWESS (LOcally-WEighted Scatter plot Smoother) algorithm computed using Spotfire S+ statistical software (TIBCO Software Inc., 2008).

The LOWESS curves (fig. 12) indicate that absolute differences between the estimates computed from observed streamflow and the DAR method generally are larger than the absolute difference between estimates computed from observed streamflow and the RRE predictions. The LOWESS curves also indicate that absolute differences between the estimates computed from observed streamflow and the WDAR method generally are smaller than the absolute difference between estimates computed from observed streamflow and the RRE predictions when the ratio of the drainage area of the ungaged gage is within about 0.5 and 1.4 times the drainage area of the streamgage. This range of DARs was used to separate the data into six groups based on estimation method and whether the DAR for the hypothetical assumed ungaged location was within the noted range. The groups were (1) DAR estimates for sites with ratios less than 0.5 and greater than 1.4 , (2) DAR estimates for sites with ratios between 0.5 and 1.4 , (3) WDAR estimates for sites with ratios less than 0.5 and greater than 1.4, (4) WDAR estimates for sites with ratios between 0.5 and 1.4, (5) RRE estimates for sites with DARs less than 0.5 and greater than 1.4, and (6) RRE estimates for sites with DARs between 0.5 and 1.4. Medians and standard deviations of the absolute differences, in percent, are presented for each group in table 18, along with the medians and standard deviations for all DAR, WDAR, and RRE estimates.

Table 18 shows that the median absolute difference, in percent, in the estimated M7D10Y low-flow statistics for the DAR and WDAR methods are about 1 and 2 percent larger, 

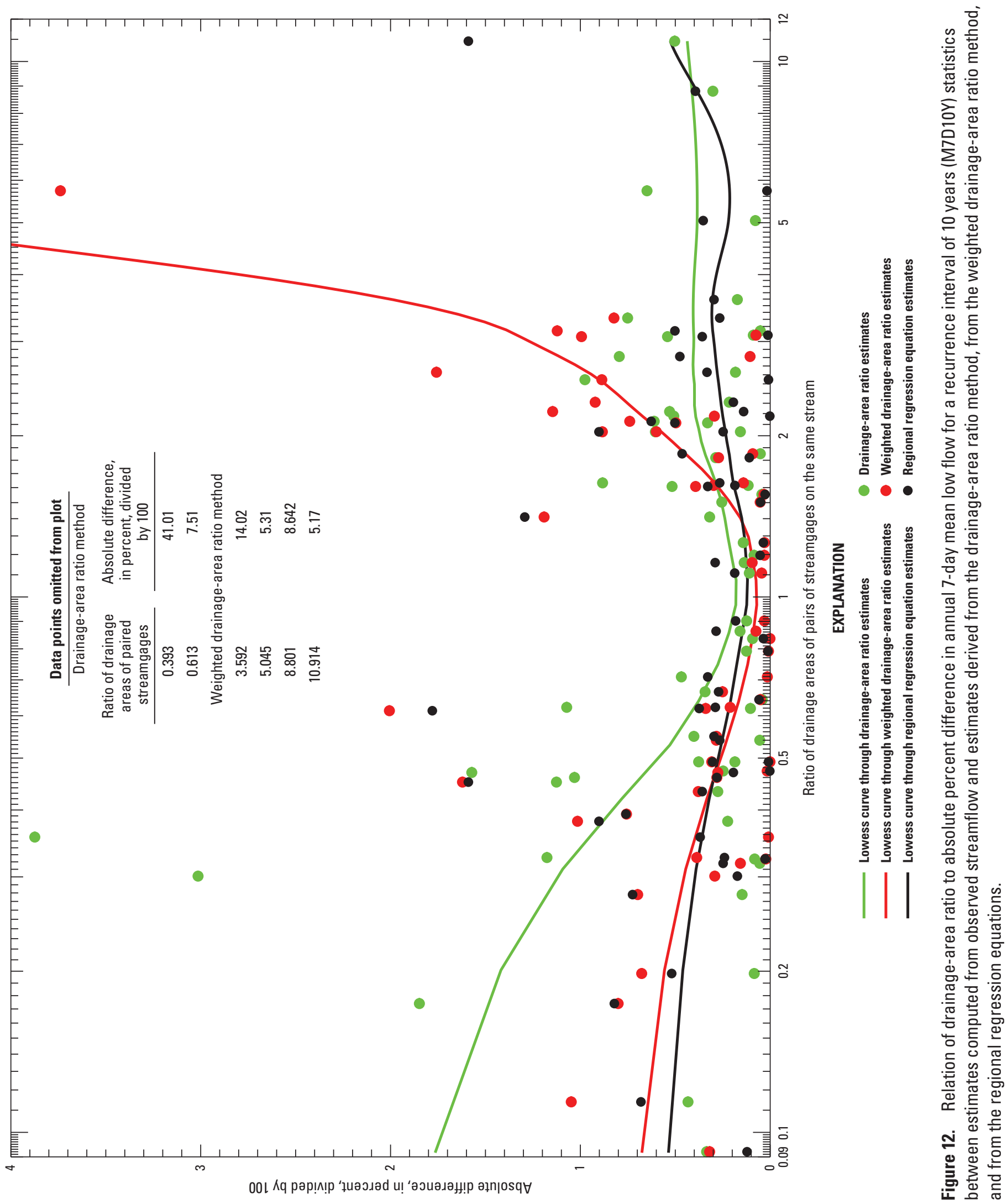
respectively, than that for the RRE equations when all the data are considered, and that the standard deviations for the DAR and WDAR methods are both much larger than that for the RRE equation. When DARs for the streamgages are between 0.5 and 1.4, the median differences for the DAR and WDAR methods are about 14 and 21 percent less, respectively, and the standard deviations are about 142 and 7 percent more, respectively, than the corresponding values for the RRE equations. When drainage area ratios for the streamgages are less than 0.5 or greater than 1.4 , the median differences for the DAR and WDAR methods are about 3 and 25 percent greater, respectively, and the standard deviations are much larger than the corresponding values for the RRE equations.

The Wilcoxon signed-rank test was computed using Spotfire S+ statistical software (TIBCO Software Inc., 2008) to determine the statistical difference between the medians of the groups. For the DAR method, this test showed that the median difference of the DAR estimates is not significantly less $(p=0.71)$ than the median difference of the RRE estimates when the DAR is between 0.5 and 1.4. The test also showed that the median difference for the DAR estimates is not significantly larger $(p=0.21)$ than the median difference for the RRE estimates when the drainage-area ratio is less than 0.5 or greater than 1.4. For the WDAR method, this test showed that the median difference of the WDAR estimates is significantly less $(p=0.01)$ than the median difference of the RRE estimates when the drainage-area ratio is between 0.5 and 1.4. The test also showed that the median difference for the WDAR estimates is significantly larger $(p=0.00)$ than the median difference for the RRE estimates when the DAR is less than 0.5 or greater than 1.4.

On the basis of the Wilcoxon signed-rank test, the WDAR method generally would provide estimates of M7D10Y that are better than estimates obtained using the RREs, when the DAR is between about 0.5 and 1.4. It is assumed that the WDAR method also may provide estimates that are better than estimates obtained using RREs for the five other selected low-flow frequency statistics and for harmonic mean flows presented in this report, when the drainage-area ratio is between 0.5 and 1.4 based on the results of the M7D10Y test. It should be noted that use of the WDAR method when the DAR is greater than 1.4 may produce negative values for some estimates (table 17). Users of the WDAR method should consider that potential errors of estimates (estimation accuracies) for individual ungaged sites cannot be quantified. If a standard error of the estimate or 90-percent prediction intervals are needed, then it may be better to use the RRE method. To summarize, on the basis of the drainage-area testing that is described in this section, a WDAR method is the preferred method for estimating low-flow frequency statistics and harmonic mean flows for an ungaged site on a gaged stream in Iowa when the DAR is between 0.5 and 1.4.

Table 18. Medians and standard deviations of absolute differences between annual mean 7-day low flow for a recurrence interval of 10 years (M7D10Y) statistics using observed streamflow and by using the drainage-area ratio method, the weighted drainage-area ratio method, and regional regression equations.

$[<$, actual value is less than value shown; $>$, actual value is greater than value shown]

\begin{tabular}{llccc}
\hline \multicolumn{1}{c}{ Group } & $\begin{array}{c}\text { Drainage-area } \\
\text { ratio range }\end{array}$ & $\begin{array}{c}\text { Number in } \\
\text { group }\end{array}$ & $\begin{array}{c}\text { Median absolute } \\
\text { difference } \\
\text { (percent) }\end{array}$ & $\begin{array}{c}\text { Standard } \\
\text { deviation }\end{array}$ \\
\hline All estimates & ALL & 186 & 29.1 & 330.2 \\
Drainage-area ratio method & ALL & 62 & 29.4 & 524.9 \\
& $<0.5$ and $>1.4$ & 46 & 33.3 & 600.5 \\
& 0.5 to 1.4 & 16 & 13.1 & 183.8 \\
Weighted drainage-area ratio & All & 62 & 30.3 & 222.2 \\
method & $<0.5$ and $>1.4$ & 46 & 54.9 & 251.4 \\
& 0.5 to 1.4 & 16 & 6.3 & 48.6 \\
Regional regression equations & ALL & 62 & 28.3 & 39.0 \\
& $<0.5$ and $>1.4$ & 46 & 30.0 & 38.3 \\
& 0.5 to 1.4 & 16 & 26.9 & 41.4 \\
\hline
\end{tabular}




\section{Example 4}

This example is a calculation of a WDAR (weighted drainage-area ratio) estimate for the M7D10Y (annual 7-day mean low flow for a recurrence interval of 10 years) statistic for a stream site in the northwest region. Streamgage 06605600 Little Sioux River at Gillette Grove is shown in fig. 1 as map number 151; this streamgage will be assumed to be an ungaged site for this example. Another streamgage 06605850 Little Sioux River at Linn Grove, is also shown in fig. 1 as map number 152, which is located downstream on the same stream; this site will be used as the streamgage in this example. This watershed is located entirely within the northwest region. Five steps are required to calculate an estimate for the WDAR method using equation 14:

$$
Q_{W D A R u}=Q_{r u}\left[R-\left(\frac{2(|\Delta D A|)(R-1)}{D A_{g}}\right)\right]
$$

The first step is to calculate $Q_{r u}$, which is the RRE predicted estimate for the ungaged site (map number 151). Using the USGS StreamStats Web-based GIS tool to measure basin characteristics for the ungaged site, DRNAREA (drainage area) is measured as 1,352.59 $\mathrm{mi}^{2}$, BFI (base-flow index) is measured as 0.569, and SOILASSURGO (hydrologic soil type A) is measured as 1.717 (table 3). Because all three basin characteristic values are within the range of values listed in table 14, the left-censored regression equation is applicable for estimating M7D10Y. The M7D10Y left-censored regression equation from table 12 is

$$
\begin{gathered}
\text { M7D10Y }=10^{-9.35} 10^{1.92(\text { DRNAREA })^{0.15}} 10^{13.5\left(\mathrm{BFI}^{2}\right.} 10^{0.134(\text { SOILASSURGO) }} \\
\text { M7D10Y }=10^{-9.35} 10^{1.92(1,352.59)^{0.15}} 10^{13.5(0.569)^{2}} 10^{0.134(1.717)} \\
\text { M7D10Y }=8.18 \mathrm{ft}^{3} / \mathrm{s}=Q_{r u}
\end{gathered}
$$

The second step is to calculate the DAR between the ungaged site and the streamgage to determine whether the WDAR method is applicable for the ungaged site. The drainage area of the ungaged site $\left(1,352.59 \mathrm{mi}^{2}\right.$, map number 151) divided by the drainage area of the streamgage $\left(\mathrm{DA}_{\mathrm{g}}\right)$ in equation $14\left(1,567.26 \mathrm{mi}^{2}\right.$, map number 152) produces a DAR of 0.863. Because this DAR is between 0.5 and 1.4, the WDAR method is applicable for the ungaged site. The third step is to calculate $|\underline{D A A}|$, which is the absolute difference between the drainage area of the ungaged site and the drainage area of the streamgage.

$$
\begin{gathered}
|\underline{\mathrm{DA}}|=1,352.59-1,567.26 \\
|\underline{\mathrm{DA}}|=214.67 \mathrm{mi}^{2}
\end{gathered}
$$

The fourth step is to calculate $\mathrm{R}$, which is the ratio of $Q_{o g}$, the M7D10Y estimate from the observed streamgage record, and $Q_{r g}$, the M7D10Y RRE predicted estimate for the streamgage; values for $Q_{o g}$ and $Q_{r g}$ are obtained from table 2 (map number 152).

$$
\begin{gathered}
R=Q_{o g} / Q_{r g} \\
R=8.55 / 11.03 \\
R=0.775
\end{gathered}
$$

The fifth step is to solve equation 14 by calculating $Q_{\text {WDARu }}$, the WDAR M7D10Y estimate for the ungaged site.

$$
\begin{gathered}
Q_{\text {WDARu }}=8.18[0.775-(2(214.67)(0.775-1) / 1,567.26)] \\
Q_{\text {WDARu }}=6.84 \mathrm{ft}^{3} / \mathrm{s} .
\end{gathered}
$$




\section{StreamStats}

StreamStats is a USGS Web-based GIS tool (http:// water.usgs.gov/osw/streamstats/index.html) that allows users to obtain streamflow statistics, drainage-basin characteristics, and other information for user-selected sites on streams. Users can select stream site locations of interest from an interactive map and can obtain information for these locations. If a user selects the location of a USGS streamgage, the user will get previously published information for the streamgage from a database. If a stream site location is selected where no data are available (an ungaged site), a GIS program will estimate information for the site. The GIS program determines the boundary of the drainage basin upstream from the stream site, measures the basin characteristics of the drainage basin, and solves the appropriate regression equations to estimate streamflow statistics for that site. The results are presented in a table and a map showing the basin-boundary outline. The estimates are applicable for stream sites not significantly affected by regulation, diversions or urbanization. In the past, it could take an experienced person more than a day to estimate this information at an ungaged site. StreamStats reduces the effort to only a few minutes.

StreamStats makes the process of computing streamflow statistics for ungaged sites much faster, more accurate, and more consistent than previously used manual methods. It also makes streamflow statistics for streamgages available without the need to locate, obtain, and read the publications in which they were originally provided. Examples of streamflow statistics that can be provided by StreamStats include the 1-percent flood probability, the median annual flow, and the mean 7-day, 10 -year low flow. Examples of basin characteristics include the drainage area, stream slope, mean annual precipitation, percent of area underlain by hydrologic soil types, and so forth. Basin characteristics provided by StreamStats are the physical, geologic, and climatic properties that have been statistically related to movement of water through a drainage basin to a stream site.

Streamflow statistics can be needed at any location along a stream and can assist with water-resources planning, management, and permitting; design and permitting of facilities such as wastewater-treatment plants and water-supply reservoirs; and design of structures such as roads, bridges, culverts, dams, locks, and levees. In addition, planners, regulators and others often need to know the physical and climatic characteristics (basin characteristics) of the drainage basins upstream from locations of interest to help them understand the processes that control water availability and water quality at these locations.

The regression equations presented in this report will be incorporated in the USGS StreamStats Web-based GIS tool (http://water.usgs.gov/osw/streamstats/index.html). StreamStats will provide users the ability to estimate six selected low-flow frequency statistics, harmonic mean flows, and 90-percent prediction intervals for ungaged stream sites in Iowa.

\section{Summary}

Reliable estimates of low-flow statistics are essential for the effective management of water resources related to watersupply planning and management, and for setting wastewatertreatment plant effluent limits and allowable pollutant loads to meet water-quality standards for irrigation, recreation, and wildlife conservation. In response to the need to update and improve the predictive accuracy of estimates of selected lowflow frequency statistics and harmonic mean flows for stream sites in Iowa, the U.S. Geological Survey, in cooperation with the Iowa Department of Natural Resources, initiated a statewide study in 2007.

Major components of the study included (1) computing seven selected statistics at 208 continuous-record streamgages within Iowa and adjacent States with at least 10 years of streamflow record using the longest, most recent period of record through September 30, 2006, without a significant trend; (2) measuring 54 basin characteristics for each streamgage that include hydrologic-characteristic measurements from five kriged grids developed for the study area; (3) developing 27 regional regression equations to estimate 7 selected statistics at ungaged stream sites based on basin characteristics; and (4) testing two drainage-area ratio methods to determine if either method provides better estimates for a selected low-flow frequency statistic for ungaged sites on gaged streams in Iowa compared to regional regression estimates and to determine the appropriate range of drainage-area ratios to use with the method.

Five Kendall's tau tests, one test for each annual and fall $\mathrm{N}$-day record, were performed for each streamgage included in the study because trends in the N-day data could introduce a bias into the selected low-flow frequency analyses. Results of the Kendall's tau tests indicated statistically significant positive trends for 133 of the 208 streamgages tested when considering the entire period of record. A variable-length-record approach to determine the longest period of record without a significant trend for all five N-day records using Kendall's tau trend analyses was selected for use for this study because it allows for longer record lengths to be included in the selected low-flow frequency analyses for many streamgages. The number of climatic years of record used for the low-flow study for the 208 streamgages ranged from 10 to 70 years with a median of 35 years. The number of years of fall record used in the study ranged from 10 to 72 years with a median of 35 years. Drainage areas of the 208 streamgages ranged from 1.4 to $7,783 \mathrm{mi}^{2}$.

Methods described in this report for estimating selected low-flow frequency statistics and harmonic mean flows are applicable to streams in Iowa that are not significantly affected by regulation, diversion, or urbanization. Estimation equations were developed for six selected low-flow frequency statistics for the annual 1-, 7-, and 30-day mean low flows for a recurrence interval of 10 years (M1D10Y, M7D10Y, and M30D10Y), the annual 30-day mean low flow for a recurrence interval of 5 years (M30D5Y), the seasonal 
(October 1 through December 31) 1- and 7-day mean low flows for a recurrence interval of 10 years (M1D10Y1012 and M7D10Y1012), and for the harmonic-mean-flow statistic (QAH).

Three regionalization approaches were investigated in this study for estimating selected low-flow frequency statistics and harmonic mean flows at ungaged sites in Iowa: statewide, regional, and region-of-influence regression. Regression analyses were used to relate physical and climatic characteristics of drainage basins to selected low-flow frequency statistics and harmonic mean flows. Data collected for 206 streamgages (excluded two streamgages because of regulation and drainage area being outside 50 miles of Iowa) were compiled into statewide, regional, and region-of-influence data sets for regression analyses. Root mean square errors (RMSEs), or average standard errors of estimate (SEE), and average standard errors of prediction (SEP) calculated for each equation for each selected low-flow frequency statistic and harmonic mean flow were compared for each regression to evaluate the predictive accuracy. Because the regional-regression provided the best predictive accuracy of the three approaches investigated, preliminary equations developed for the statewide and region-of-influence methods are not listed in this report.

The study area, which included all of Iowa and adjacent areas (within 50 miles of the State border) of neighboring States, was divided into three low-flow regions on the basis of hydrologic characteristics, landform regions, and soil regions. Because a significant number of streams in Iowa reach zero flow as their minimum flow during low-flow years, four different types of regression analyses were performed to develop the final equations for the three low-flow regions-left-censored, logistic-, WLS-, and GLS-regression analyses. For the northeast and northwest regions, left-censored regression analyses were performed to allow the use of a censoring threshold in the development of equations to estimate the six low-flow frequency statistics, and a weighted least-square (WLS) regression analysis was used to develop an equation to estimate QAH. For the southern region, logistic-regression analyses were performed to develop equations to estimate the probability of zero flow for the six low-flow frequency statistics, and generalized least-squares (GLS) regression analyses were used to develop six equations to estimate nonzero low-flow frequency statistics and WLS regression analysis was used to develop an equation to estimate QAH. The logistic-regression equations should be used to estimate the probability of zero flow for ungaged stream sites in the southern region, before GLS equations are used, if necessary, to estimate nonzero low-flow frequency statistics. If the resulting probability of zero flow is greater than or equal to 0.5 , then the value for that low-flow frequency statistic is estimated to be zero flow, and the associated GLS-regression equation should not be used.

Preliminary multiple-linear-regression analyses, using ordinary least-squares regression (OLS), were conducted to test for significant differences among the low-flow regions and to identify the most significant basin characteristics for inclusion in the GLS, WLS, logistic, and left-censored regressions.
The final regression analyses included 192 streamgages after 14 additional streamgages were removed from the regression data set. These additional 14 streamgages were removed because they were flagged as outliers in the regression analyses and were identified by field personnel as possibly being affected by alterations of flow.

All 54 basin characteristics measured for each streamgage were determined from digital databases using geographic information system (GIS) software. Ten basin characteristics are used as explanatory variables in the final regression equations; these include three morphometric characteristics: drainage area (DRNAREA), drainage frequency (DRNFREQ), and relative stream density (RSD); three hydrologic characteristics: base-flow index (BFI), annual base-flow-recession time constant (TAU_ANN), and streamflow-variability index (STREAM_VAR); and four pedologic characteristics: hydrologic soil type A (SOILASSURGO), hydrologic soil type B (SOILBSSURGO), hydrologic soil type C (SOILCSSURGO), and average soil permeability (KSATSSUR). Predictive accuracies for the selected low-flow frequency equations developed for each region are indicated by several performance metrics. SEEs for the left-censored equations for the northeast region range from 64.7 to 88.1 percent and for the northwest region range from 85.8 to 111.8 percent. Misclassification percentages for the logistic equations for the southern region range from 5.6 to 14.0 percent. SEPs for GLS equations for the southern region range from 71.1 to 98.9 percent, and the pseudo coefficients of determination (pseudo- $\mathrm{R}^{2}$ ) for the GLS equations range from 87.7 to 91.8 percent. SEPs for WLS equations developed to estimate QAH for each of the three regions range from 66.4 to 80.4 percent. Although SEE and SEP performance metrics are not directly comparable between the regional equations, in general, predictive accuracies tend to be the best for the northeast region, second best for the southern region, and poorest for the northwest region. Of the six low-flow frequency equations developed for each region, the M7D10Y1012, M1D10Y1012, and M30D5Y regression equations generally have the best predictive accuracy and the M30D10Y and M7D10Y equations generally have the poorest accuracy.

Two drainage-area ratio (DAR) methods were compared with the regional regression equations using 31 pairs of streamgages to determine the most accurate method to use for ungaged sites on gaged streams in Iowa and to determine the appropriate range of DARs between a streamgage and an ungaged stream site. A simple DAR method, a weighted drainage-are ratio (WDAR) method, and the regional-regression equation (RRE) results were compared to the M7D10Y statistic computed from observed streamflow. Results of the testing indicate the WDAR method is the preferred method because it provides better estimates for the M7D10Y statistic compared to the other two methods for an ungaged site on a gaged stream in Iowa when the DAR is between 0.5 and 1.4.

The regional-regression equations developed in this study are not intended for use at ungaged stream sites in which the basin characteristics are outside the range of those used to 
develop the equations. Inconsistencies in estimates may result for the frequency equation estimates, if basin-characteristic values approach the minimum or maximum limits of the range. Selected low-flow frequency statistics and harmonic mean flows estimated by the equations represent flow conditions in Iowa not significantly affected by regulation, diversion, or urbanization. The regression equations should be used with caution in areas where low flows are affected by significant gains as a result of large springs or significant losses as a result of sinkholes common to karst topography. If the equations are used at ungaged sites on regulated streams, or on streams affected by water-supply and agricultural withdrawals, then the estimates will need to be adjusted if actual flow conditions are of interest.

GIS software is required to measure the basin characteristics included as explanatory variables in the regression equations. Low-flow frequency estimates calculated from censored regression equations that are 0.1 cubic feet per second $\left(\mathrm{ft}^{3} / \mathrm{s}\right)$, or lower, should be reported as less than $0.1 \mathrm{ft}^{3} / \mathrm{s}$. Selected low-flow frequency and harmonic-mean-flow estimates calculated to be lower than $0.1 \mathrm{ft}^{3} / \mathrm{s}$ from GLS regression equations for the southern region or from WLS regression equations for all three low-flow regions, also should be reported as less than $0.1 \mathrm{ft}^{3} / \mathrm{s}$ to maintain a consistent prediction-dischargereporting limit for Iowa.

All 27 regression equations developed for this study are to be included in the USGS StreamStats Web-based GIS tool. StreamStats will provide users with a set of annual and seasonal low-flow frequency and harmonic-mean-flow estimates for ungaged stream sites within Iowa in addition to the basin characteristics for the sites. Ninety-percent prediction intervals also are automatically calculated. A 90-percent prediction interval denotes there is 90-percent certainty that the true value of a low-flow frequency or harmonic-mean-flow statistic at an ungaged stream site will be within a plus or minus interval around the predicted low-flow frequency or harmonicmean-flow statistic.

\section{Acknowledgments}

The authors gratefully acknowledge the following USGS personnel: Julie Kiang, for her assistance with many parts of the regression analyses, particularly with regional regression analyses for zero flows; Kris Lund; for her work to prepare GIS base data layers required for StreamStats; Rochelle Galer, for her work to measure basin characteristics for streamgages, to prepare base GIS data layers required for StreamStats and for areas in neighboring States, to prepare SSURGO data layers required for use with the Soil Data Viewer, and to test Iowa precipitation data for trends; Gabe Ritter, for his work to prepare GIS base data layers required for StreamStats, and to create programs for calculating STREAM_VAR and for improving the efficiency of calculating BFI; Ken Eng, for his assistance with the measurement of TAU_ANN and
TAU 1012; Ed Fischer, for his work to create scripts for automating the computations from SWSTAT, HYSEP, and BIOFLO, and Mike Linhart, for his work to develop preliminary statewide RoI regression equations for each of the seven selected low-flow statistics. The authors would also like to express their appreciation to the many other USGS personnel who assisted with collection and analysis of streamflow data used in this study.

\section{References Cited}

Ahearn, E.A., 2010, Regional regression equations to estimate flow-duration statistics at ungaged stream sites in Connecticut: U.S. Geological Survey Scientific Investigations Report 2010-5052, 45 p. (Also available at http://pubs.usgs.gov/ sir/2010/5052/.)

Bent, G.C., and Steeves, P.A., 2006, A revised logistic regression equation and an automated procedure for mapping the probability of a stream flowing perennially in Massachusetts: U.S. Geological Survey Scientific Investigations Report 2006-5031, 107 p., 1 CD-ROM. (Also available at http://pubs.usgs.gov/sir/2006/5031/.)

Bossong, C.R., Karlinger, M.R., Troutman, B.M., and Vecchia, A.V., 1999, Overview and technical and practical aspects for use of geostatistics in hazardous-, toxic-, and radioactive-waste-site investigations: U.S. Geological Survey Water-Resources Investigations Report 98-4145, 70 p.

Boussinesq, J., 1903, Sur le de'bit, en temps de s'echeresse, d'une source allimente'e par une nappe d' eaux d' infiltration: Comptes Rendus Hebdomadaires des Seances de l'Academie des Sciences, v. 136, p. 1511-1517.

Brutsaert, W., and Lopez, J.P., 1998, Basin-scale geohydrologic drought flow features of riparian aquifers in the southern Great Plains: Water Resources Research, v. 34, no. 2, p. 233-240, accessed April 7, 2011, at http://www.agu.org/ journals/wr/v034/i002/97WR03068/97WR03068.pdf.

Brutsaert, W., and Nieber, J.L., 1977, Regionalized drought flow hydrographs from a mature glaciated plateau: Water Resources Research, v. 13, no. 3, p. 637-643, accessed April 7, 2011, at http://www.agu.org/journals/wr/v013/i003/ WR013i003p00637/WR013i003p00637.pdf.

Burn, D.H., 1990, Evaluation of regional flood frequency analysis with region of influence approach: Water Resources Research, v. 26, no. 10, p. 2257-2265, accessed April 11, 2011, at http://www.agu.org/journals/wr/v026/i010/ WR026i010p02257/WR026i010p02257.pdf. 
Cohn, T.A., 1988, Adjusted maximum likelihood estimation of the moments of lognormal populations from type I censored samples: U.S. Geological Survey Open-File Report 88-350, $34 \mathrm{p}$.

Cook, R.D., 1977, Detection of influential observation in linear regression: Technometrics, v. 19, p. 15-18, accessed April 7, 2011, at: http://www.ime.usp.br/ abe/lista/ pdfWiH1zqnMHo.pdf.

Eash, D.A., 2001, Techniques for estimating flood-frequency discharges for streams in Iowa: U.S. Geological Survey Water-Resources Investigations Report 00-4233, 88 p. (Also available at http://ia.water.usgs.gov/pubs/reports/ WRIR_00-4233.pdf.)

Efroymson, M.A., 1960, Multiple regression analysis, in Ralston, A., and Wilf, H.S., eds., Mathematical methods for digital computers: New York, John Wiley and Sons, Inc., p. 191-203.

Eng, K., and Brutsaert, W., 1999, Generality of drought flow characteristics within the Arkansas River Basin: Journal Geophysical Research, v. 104, no. D16, p. 19435-19441, accessed April 7, 2011, at http://www.agu.org/journals/jd/ v104/iD16/1999JD900087/1999JD900087.pdf.

Eng, Ken, Tasker, G.D., and Milly, P.C.D., 2005, An analysis of region-of-influence methods for flood regionalization in the Gulf-Atlantic Rolling Plains: Journal of American Water Resources Association, v. 41, no. 1, p. 135-143, accessed April 11, 2011, at http://water.usgs.gov/nrp/proj.bib/ Publications/2005/eng_tasker_etal_2005.pdf.

Eng, K., and Milly, P.C.D., 2007, Relating low-flow characteristics to the base flow recession time constant at partial record stream gauges: Water Resources Research, v. 43, W01201, doi:10.1029/2006WR005293, accessed April 7, 2011, at http://www.agu.org/journals/wr/wr0701/2006WR00 5293/2006WR005293.pdf.

Eng, Ken, Milly, P.C.D., and Tasker, G.D., 2007, Flood regionalization: a hybrid geographic and predictor-variable region-of-influence regression method: Journal of Hydrologic Engineering, ASCE, v. 12, no. 6, p. 585-591, accessed April 11, 2011, at http://scitation.aip.org/getpdf/servlet/Get PDFServlet? filetype $=p d f \& i d=J H Y E F F 00001200000600$ $0585000001 \&$ idtype $=$ cvips \& doi $=10.1061 /($ ASCE) 1084 0699(2007)12:6(585)\&prog=normal.

Eng, Ken, Chen, Yin-Yu, and Kiang, J.E., 2009, User's guide to the weighted-multiple-linear-regression program (WREG version 1.0): U.S. Geological Survey Techniques and Methods, book 4, chap. A8, 21 p. (Also available at http://pubs. usgs.gov/tm/tm 4 a8/.)
Environmental Systems Research Institute, Inc., 2001, ArcGIS geostatistical analyst, Statistical tools for data exploration, modeling, and advanced surface generation: Redlands, Calif., Environmental Systems Research Institute, Inc., 23 p., accessed April 7, 2011, at http://www.esri.com/ library/whitepapers/pdfs/geostat.pdf.

Environmental Systems Research Institute, Inc., 2009, ArcGIS desktop help, accessed April 7, 2011, at http://webhelp.esri. com/arcgisdesktop/9.3.

Esralew, R.A., and Lewis, J.M., 2010, Trends in base flow, total flow, and base-flow index of selected streams in and near Oklahoma through 2008: U.S. Geological Survey Scientific Investigations Report 2010-5104, 143 p. (Also available at $h t t p: / / p u b s . u s g s . g o v / s i r / 2010 / 5104 /$.

Flynn, K.M., Hummel, P.R., Lumb, A.M., and Kittle, J.L., Jr., 1995, User's manual for ANNIE, version 2, a computer program for interactive hydrologic data management: U.S. Geological Survey Water-Resources Investigations Report 95-4085, 211 p. (Also available at http://water.usgs. gov/software/ANNIE/.)

Funkhouser, J.E., Eng, K., and Moix, M.W., 2008, Low-flow characteristics and regionalization of low-flow characteristics for selected streams in Arkansas: U.S. Geological Survey Scientific Investigations Report 2008-5065, 161 p. (Also available at $h t t p: / / p u b s . u s g s . g o v / s i r / 2008 / 5065 /$.

Gesch, D.B., 2007, The National Elevation Dataset, in Maune, D., ed., Digital Elevation Model technologies and applications: The DEM Users Manual, 2d ed.: Bethesda, Maryland, American Society for Photogrammetry and Remote Sensing, p. 99-118, accessed April 7, 2011, at http://topotools. cr.usgs.gov/pdfs/Gesch_Chp_4_Nat_Elev_Data_2007.pdf, see also http://ned.usgs.gov/.

Griffis, V.W., and Stedinger, J.R., 2007, The use of GLS regression in regional hydrologic analyses: Journal of Hydrology, v. 344, p. 82-95, accessed April 8, 2011, at http://www.sciencedirect.com/ science?_ob=ArticleURL\&_udi=B6V6C-4P4FVB6-5\&_ user $=696292 \&$ _coverDate $=09 \% 2 F 30 \% 2 F 2007 \&$ $r d o c=1 \&$ fmt $=$ high\&_orig $=$ gateway\&_ origin $=$ gateway\&_sort $=d \& \_d o c a n c h o r=\& v i e w=c \&$ searchStrId $=1710990029 \&$ rerunOrigin $=$ google\&_ acct $=C 000038819$ \&_version $=1 \& \_u r l$ Version $=0$ \&_userid $=$ 696292\&md5=184db778baelda5c1274cb01de303855\&se archtype $=a$.

Heinitz, A.J., 1970, Low-flow characteristics of Iowa streams through 1966: Iowa Natural Resources Council Bulletin, no. $10,176 \mathrm{p}$. 
Helsel, D.R., and Hirsch, R.M., 2002, Statistical methods in water resources: U.S. Geological Survey Techniques of Water-Resources Investigations, book 4, chap. A3, 510 p. (Also available at http://pubs.usgs.gov/twri/twri4a3/html/ pdf_new.html.)

Homer, Collin, Huang, Chengquan, Yang, Limin, Wylie, Bruce, and Coan, Michael, 2004, Development of a 2001 National Land-Cover Database for the United States: Photogrammetric Engineering and Remote Sensing, v. 70, no. 7, July 2004, p. 829-840, accessed April 7, 2011, at http://www.mrlc.gov/pdf/July_PERS.pdf, also see http:// www.mrlc.gov/index.php.

Horick, P.J., and Soenksen, P.J., 1989, Water resources of northeast Iowa: Iowa Department of Natural Resources, Geological Survey Bureau, Water Atlas 8, 133 p., accessed April 8, 2011, at http://www.igsb.uiowa.edu/Mapping/ abstract/wa8.htm.

Hortness, J.E., 2006, Estimating low-flow frequency statistics for unregulated streams in Idaho: U.S. Geological Survey Scientific Investigations Report 2006-5035, 31 p. (Also available at http://pubs.usgs.gov/sir/2006/5035/.)

Iman, R.L., and Conover, W.J., 1983, A modern approach to statistics: New York, John Wiley and Sons, Inc., 497 p.

Institute of Hydrology, 1980a, Low flow studies: Wallingford, Oxon, United Kingdom, Report no. 1, 41 p.

Institute of Hydrology, 1980b, Low flow studies: Wallingford, Oxon, United Kingdom, Report no. 3, p. 12-19.

Interagency Advisory Committee on Water Data, 1982, Guidelines for determining flood flow frequency: Reston, Va., Hydrology Subcommittee Bulletin 17B, 28 p. and appendixes, accessed April 7, 2011, at http://water.usgs.gov/osw/ bulletin 17b/dl_flow.pdf.

Iowa Department of Natural Resources and the U.S. Environmental Protection Agency, 2010, The FINAL 2010 Iowa list of Section 303(d) Impaired Waters: Technical Fact Sheet, accessed February 29, 2012, at http://www. iowadnr.gov/Portals/idnr/uploads/watermonitoring/ impairedwaters $/ 2010 /$ Fact\%20Sheet\%20for\%20Finalapproved\%202010\%20list.pdf.

Iowa Natural Resources Council, 1958, An inventory of water resources and water problems, northeastern Iowa river basins: Des Moines, Iowa, Iowa Natural Resources Council Bulletin, no. 7, 74 p.

Koltun, G.F., and Schwartz, R.R., 1986, Multiple-regression equations for estimating low flows at ungaged stream sites in Ohio: U.S. Geological Survey Water-Resources Investigations Report 86-4354, 39 p., 6 pls. (Also available at http://pubs.er.usgs.gov/publication/wri864354.)
Koltun, G.F., and Whitehead, M.T., 2002, Techniques for estimating selected streamflow characteristics of rural, unregulated streams in Ohio: U.S. Geological Survey Water-Resources Investigations Report 02-4068, 50 p. (Also available at http://oh.water.usgs.gov/reports/wrir/ wrir02-4068.pdf.)

Kroll, C.N., and Stedinger, J.R., 1996, Estimation of moments and quantiles using censored data: Water Resources Research, v. 32, no. 4, p. 1005-1012, accessed April 8, 2011, at http://www.esf.edu/ere/kroll/estimation_of_ moments_cencosred_data.pdf.

Kroll, C.N., and Vogel, R.M., 2002, Probability distribution of low streamflow series in the United States: Journal of Hydrologic Engineering, v. 7, no. 2, p. 137-146, accessed April 8, 2011, at http://engineering.tufts.edu/cee/people/ vogel/publications/probability-low.pdf.

Kroll, Chuck, Luz, Joana, Allen, Brad, Vogel, R.M., 2004, Developing a watershed characteristics database to improve low streamflow prediction: Journal of Hydrologic Engineering, v. 9, no. 2, p. 116-125, accessed April 11, 2011, at http://www.esf.edu/ere/kroll/developingDatabase.pdf.

Lane, E.W., and Lei, Kai, 1950, Stream flow variability: Proceedings of American Society of Civil Engineers, Transactions, v. 115, p. 1084-1134.

Lara, O.G., 1979, Annual and seasonal low-flow characteristics of Iowa streams: U.S. Geological Survey Open-File Report 79-555, Iowa Natural Resources Council Bulletin, no. 13, 507 p., accessed April 7, 2011, Plates 3 and 4 available at ftp://ftp.igsb.uiowa.edu/gis_library/IA_State/ Hydrologic/Surface_Waters/USGS_stream_low_flow_ Plate3.html and ftp://ftp.igsb.uiowa.edu/gis_library/ IA_State/Hydrologic/Surface_Waters/USGS_stream_low_ flow_Plate4.html.

Lins, Harry, 2005, Streamflow trends in the United States: U.S. Geological Fact Sheet 2005-3017, 4 p. (Also available at http://pubs.usgs.gov/fs/2005/3017/.)

Lorenz, D.L., and others, 2011, USGS library for S-PLUS for windows - Release 4.0: U.S. Geological Survey Open-File Report 2011-1130, accessed February 7, 2012, at http:// water.usgs.gov/software/S-PLUS/.

Ludwig, A.H., and Tasker, G.D., 1993, Regionalization of low flow characteristics of Arkansas streams: U.S. Geological Survey Water-Resources Investigations Report 93-4013, 19 p. (Also available at http://pubs.usgs.gov/wri/1993/4013/ report.pdf.) 
Lumb, A.M., Kittle, J.L., Jr., and Flynn, K.M., 1990, Users manual for ANNIE, a computer program for interactive hydrologic analyses and data management: U.S. Geological Survey Water-Resources Investigations Report 89-4080, 236 p. (Also available at http://water.usgs.gov/software/ ANNIE/.)

Marquardt, D.W., 1970, Generalized inverses, ridge regression, biased linear estimation, and nonlinear estimation: Technometrics, v. 12, no. 3, p. 591-612, accessed April 11, 2011, at http://www.jstor.org/stable/1267205.

Martin, G.R., and Arihood, L.D., 2010, Methods for estimating selected low-flow frequency statistics for unregulated streams in Kentucky: U.S. Geological Survey Scientific Investigations Report 2010-5217, 83 p. (Also available at http://pubs.usgs.gov/sir/2010/5217/.)

Martin, G.R., and Ruhl, K.J., 1993, Regionalization of harmonic-mean streamflows in Kentucky: U.S. Geological Survey Water-Resources Investigations Report 92-4173, 47 p., 1 pl. (Also available at http://pubs.usgs.gov/wri/ wri924173/index.html\#pdf.)

McCabe, G.J., and Wolock, D.M., 2002. A step increase in streamflow in the conterminous United States: Geophysical Research Letter, v. 29, p. 2185-2188. (Also available at http://ks.water.usgs.gov/pubs/reports/dmw.grl.v29.html.)

Miller, A.M., and Golladay, S.W., 1996, Effects of spates and drying on macroinvertebrate assemblages of an intermittent and a perennial stream: Journal of North American Benthological Society, v. 15 , no. 4, p. 670-689, accessed June 7, 2011, at http://www.jstor.org/sici? sici=08873593\%28199612\%2915\%3A4\%3C670\%3AEOSADO\%3E2 $.0 . C O \% 3 B 2-9 \&$.

Multi-Resolution Land Characteristics Consortium (MRLC), 2012, National Land Cover Database (NLCD): accessed May 1, 2012, at http://www.mrlc.gov/index.php.

National Climatic Data Center, 2012, Climate of Iowa, accessed April 30, 2012, at http://www.crh.noaa.gov/ images/dvn/downloads/Clim_IA_01.pdf.

National Cooperative Soil Survey and Natural Resources Conservation Service, 2012, Iowa Soil Regions Based on Parent Materials, accessed August 15, 2012, at ftp://ftp-fc.sc.egov. usda.gov/IA/technical/IowaSoilRegionsMap.html.

Oschwald, W.R., Riecken, F.F., Dideriksen, R.I., Scholtes, W.H., and Schaller, F.W., 1965, Principal soils of Iowa: Ames, Iowa, Iowa State University, Department of Agronomy, Special Report, no. 42, 77 p.
Pettyjohn, W.A., and Henning, Roger, 1979, Preliminary estimate of ground-water recharge rates, related streamflow and water quality in Ohio: Ohio State University Water Resources Center Project Completion Report Number 552, 323 p., accessed April 7, 2011, at https://kb.osu.edu/dspace/ bitstream/1811/36354/1/OH_WRC_552.pdf.

Prior, J.C., 1991, Landforms of Iowa: Iowa City, University of

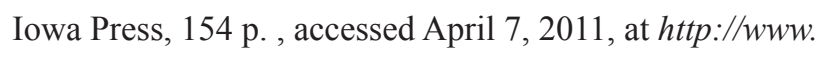
igsb.uiowa.edu/Browsellandform.htm.

Prior, J.C., Kohrt, C.J., and Quade, D.J., 2009, The landform regions of Iowa, vector digital data: Iowa Geological Survey, Iowa Department of Natural Resources, Iowa City, Iowa, accessed April 7, 2011, at ftp://ftp.igsb.uiowa.edu/ gis_library/ia_state/geologic/landform/landform_regions. zip.

PRISM Climate Group, 2008, Normal annual precipitation grid for the conterminous United States, accessed April 7, 2011, at http://www.prism.oregonstate.edu/state_products/ maps.phtml?id=US, also see http://www.prism.oregonstate. edu/pub/prism/docs/prisguid.pdf.

Riggs, H.C., 1972, Low-flow investigations: U.S. Geological Survey Techniques of Water-Resources Investigations, book 4, chap. B1, 18 p. , accessed April 7, 2011, at http:// pubs.usgs.gov/twri/twri4b1/index.html.

Ries, K.G., and Friesz, P.J., 2000, Methods for estimating low-flow statistics for Massachusetts streams: U.S. Geological Survey Water-Resources Investigations Report 00-4135, 81 p. (Also available at http://pubs.usgs.gov/wri/ wri004135/.)

Risley, John, Stonewall, Adam, and Haluska, Tana, 2008, Estimating flow-duration and low-flow frequency statistics for unregulated streams in Oregon: U.S. Geological Survey Scientific Investigations Report 2008-5126, 22 p. (Also available at $h t t p: / / p u b s . u s g s . g o v /$ sir/2008/5126/.)

Rossman, L.A., 1990a, Design stream flows based on harmonic means: Journal of Hydraulic Engineering, v. 116, no. 7, p. 946-950. 
Rossman, L.A., 1990b, DFLOW user's manual: Cincinnati, Ohio, U.S. Environmental Protection Agency, Risk Reduction Engineering Laboratory, 26 p. , accessed April 7, 2011, at http://nepis.epa.gov/Exe/ZyNET.exe/30001JEH.TXT?ZyA ctionD $=$ ZyDocument\&Client $=E P A \& I n d e x=1986+$ Thru +19 $90 \&$ Docs $=\&$ Query $=600890051 \% 20$ or\%20dflow $\% 20$ or $\% 20$ user's\%20or\%20manual\%20or\%20rossman\&Time $=\&$ EndTime $=\&$ SearchMethod $=1 \&$ TocRestrict $=n \&$ Toc $=\&$ TocEntry $=\& Q$ Field $=$ pubnumber $\% 5 E \% 22600890051 \% 22 \& Q$ Field $Y$ ear $=\&$ QFieldMonth $=\&$ QFieldDay $=\&$ UseQField $=$ pubnum ber\&IntQFieldOp $=1 \&$ ExtQFieldOp $=1 \&$ XmlQuery $=\&$ File $=D \% 3 \mathrm{~A} \% 5$ Czyfiles $\% 5$ CIndex $\% 20$ Data\%5C86thru $90 \% 5 \mathrm{C}$ Txt\%5C00000005\%5C30001JEH.txt\&User $=$ ANONYMOU $S \&$ Password $=$ anonymous\&SortMethod $=h \% 7 C-\&$ Maximu mDocuments $=10 \&$ FuzzyDegree $=0 \&$ ImageQuality $=r 75 \mathrm{~g} 8 /$ $r 75 g 8 / x 150 y 150 g 16 / i 425 \&$ Display $=p \% 7 C f \&$ DefSeekPage $=x \&$ SearchBack $=Z y$ ActionL\&Back $=Z y$ ActionS\&BackDesc $=$ Results\%20page\&MaximumPages $=1 \& Z y$ Entry $=1 \&$ SeekP age $=x \& Z y P U R L$.

Rowden, R.D., Libra, R.D., and Hallberg, G.R., 1995, Surface water monitoring in the Big Spring Basin 1986-1992, A summary review: Iowa Department of Natural Resources Geological Survey Bureau Technical Information Series 33, 109 p., accessed April 8, 2011, at http://www.igsb.uiowa. edu/webapps/gsbpubs/pdf/TIS-33.pdf.

Runkel, R.L., Crawford, C.G., and Cohn, T.A., 2004, Load estimator (LOADEST): A FORTRAN program for estimating constituents loads in streams and rivers: U.S. Geological Survey Techniques and Methods, book 4, chap. A5, 69 p. (Also available online at http://pubs.usgs.gov/tm/2005/ tm4A5/pdf/508final.pdf.)

Schilling, K.E., 2005, Relation of baseflow to row crop intensity in Iowa: Agriculture, Ecosystems and Environment, v. 105, no. 1-2, p. 433-438, accessed April 7, 2011, at http://www.sciencedirect.com/science?_ob=ArticleURL\&_ $u d i=B 6 T 3 Y-4 C P D 8 F G-3 \& \_u s e r=696292 \&$ coverDate $=01 \% 2 F 31 \% 2 F 2005 \& \_r d o c=1 \&$ fmt $=$ high \& orig $=$ gateway\&_origin $=$ gateway\&_sort $=d \&$ docanchor $=\&$ view $=c \&$ searchStrId $=1709861362 \&$ rerunOrigin $=$ google\&_acct $=C 000038819 \& \_$version $=1 \&$ _ urlVersion $=0 \& \_u s e r i d=696292 \& m d 5=83 e 59 e 04 a f f 6 f f f 8 a f b$ fdb57a097318c\&searchtype $=a$.
Schilling, K.E., and Libra, R.D., 2003, Increased baseflow in Iowa over the second half of the 20th century: Journal of American Water Resources Association, v. 39, no. 4, p. 851-860, accessed April 7, 2011, at http://onlinelibrary. wiley.com/doi/10.1111/j.1752-1688.2003.tb04410.x/pdf.

Schwob, H.H., 1958, Low-flow characteristics of Iowa streams: Iowa Natural Resources Council Bulletin, no. 9, $111 \mathrm{p}$.

Searcy, J.M., 1959, Flow-duration curves, manual of hydrology-Part 2, low-flow techniques: U.S. Geological Survey Water Supply Paper 1542-A, 33 p. (Also available at $h t t p: / /$ pubs.er.usgs.gov/publication/wsp1542A.)

Simley, J.D., and Carswell, W.J., Jr., 2009, The National Map-Hydrography: U.S. Geological Survey Fact Sheet 2009-3054, 4 p. (Also available at http://pubs.usgs.gov/ fs/2009/3054/, also see http://nhd.usgs.gov/.)

Sloto, R.A., and Crouse, M.Y., 1996, HYSEP, A computer program for streamflow hydrograph separation and analysis: U.S. Geological Survey Water-Resources Investigations Report 96-4010, 46 p. (Also available at http://pubs.usgs. gov/wri/1996/4040/report.pdf.)

Smakhtin, V.U., 2001, Low flow hydrology, a review: Journal of Hydrology, v. 240, Issues 3-4, p. 147-186, accessed April 7, 2011, at http://www.sciencedirect.com/ science?_ob=ArticleURL\&_udi $=$ B6V6C-420SJJR-1\&_ user $=696292 \&$ coverDate $=01 \% 2 F 10 \% 2 F 2001 \&$ $r d o c=1 \&$ fmt $=$ high\&_orig $=$ gateway\&_ origin $=$ gateway \&_sort $=d \& \_d o c a n c h o r=\& v i e w=c \&$ searchStrId $=1709981733 \&$ rerunOrigin $=$ google\&_ acct $=$ C000038819\&_version $=1 \& \_u r l$ Version $=0$ \&_userid $=$ $696292 \& m d 5=4 d 5 b 6240162 e 8 b c b d 48 f 6 b 59 d 936 e 55 f \& s e a$ rchtype $=a$.

Small, David, Islam, Shafiqul, and Vogel, R.M., 2006, Trends in precipitation and streamflow in the eastern U.S., Paradox or perception?: Geophysical Research Letters, v. 33, LO3403, 4 p., accessed April 7, 2011, at http://engineering. tufts.edu/cee/people/vogel/publications/trends-streamflow. $p d f$.

Soenksen, P.J., and Eash, D.A., 1991, Iowa floods and droughts, in National Water Summary 1988-89-Hydrologic events and floods and droughts: U.S. Geological Survey Water-Supply Paper 2375. (Also available at $h t t p: / /$ pubs.er.usgs.gov/publication/wsp2375.) 
Soil Survey Staff, 2012, Natural Resources Conservation Service, U.S. Department of Agriculture, Soil Survey Geographic (SSURGO) Database for all counties included in study area shown in figure 1, accessed April 30, 2012, at http://soildatamart.nrcs.usda.gov/.

Stedinger, J.R. and Tasker, G.D., 1985, Regional hydrologic analysis 1 - Ordinary, weighted, and generalized least square compared: Water Resources Research, v. 21, no. 9, p. 1421-1432, accessed April 8, 2011, at http:// www.agu.org/journals/wr/v021/i009/WR021i009p01421/ WR021i009p01421.pdf.

Straub, D.E., 2001, Low-flow characteristics of streams in Ohio through water year 1997: U.S. Geological Survey Water-Resources Investigations Report 01-4140, 415 p. (Also available at $h t t p: / / o h$.water.usgs.gov/reports/wrir/ wrir01-4140.pdf.)

Tasker, G.D., 1980, Hydrologic regression with weighted least squares: Water Resources Research, v. 16, no. 6, p. 1107-1113, accessed April 8, 2011, at http://www. agu.org/journals/wr/v016/i006/WR016i006p01107/ WR016i006p01107.pdf.

Tasker, G.D., and Driver, N.E., 1988, Nationwide regression models for predicting urban runoff water quality at unmonitored sites: Water Resources Bulletin, v. 24, no. 5, p. 1091-1101, accessed April 8, 2011, at http:// onlinelibrary.wiley.com/doi/10.1111/j.1752-1688.1988. tb03026.x/pdf.

Tasker, G.D., and Stedinger, J.R., 1989, An operational GLS model for hydrologic regression: Journal of Hydrology, v. 111, p. 361-375, accessed April 8, 2011, at http:// www.sciencedirect.com/science? ob=ArticleURL\& $u d i=B 6 V 6 C-487 D D 3 J-S K \& \_u s e r=696292 \&$ coverDate $=12 \% 2 \mathrm{~F} 31 \% 2 \mathrm{~F} 1989 \& \_r d o c=1 \&$ fmt $=$ high \& orig $=$ gateway\&_origin $=$ gateway\&_sort $=d \&$ docanchor $=\&$ view $=c \&$ searchStrId $=1710988392 \&$ rerunOrigin $=$ google\&_acct $=C 000038819 \&$ \&ersion $=1$ \& urlVersion $=0 \& \_u s e r i \bar{d}=696292 \& m d 5=f 5 f 3 \overline{11} 6 e 25045 e 1 \overline{b b}$ 991f7d08c4f4603\&searchtype $=a$.

TIBCO Software Inc., 2008, TIBCO Spotfire S+ 8.1 for Windows ${ }^{\circledR}$ User's Guide: Palo Alto, Calif., 582 p., accessed May 1, 2012, at http://www.msi.co.jp/splus/support/ download/V81/getstart.pdf

U.S. Department of Agriculture, Natural Resources Conservation Service, 2012, Geospatial data gateway: U.S. Department of Agriculture, accessed March 30, 2012, at http:// datagateway.nrcs.usda.gov/.

U.S. Department of Agriculture, Natural Resources Conservation Service, 2012, Soil data mart: U.S. Department of Agriculture, accessed May 1, 2012, at http://soildatamart. nrcs.usda.gov/SDM\%20Web\%20Application/default.aspx.
U.S. Environmental Protection Agency, 2011, accessed February 29, 2012, at http://www.iowadnr.gov/Portals/idnr/ uploads/watermonitoring/impairedwaters/2010/IA\%20 2010\%20Integrated\%20Report_Cat-5_30Jun2011.pdf.

U.S. Geological Survey, 2012, National hydrography dataset: U.S. Geological Survey, accessed April 30, 2012, at http:// nhd.usgs.gov/.

U.S. Geological Survey, 2012, National elevation dataset: U.S. Geological Survey, accessed April 30, 2012, at http://ned.usgs.gov/.

U.S. Geological Survey, 2012, Welcome to StreamStats: U.S. Geological Survey, accessed April 30, 2012, at http://water. usgs.gov/osw/streamstats/index.html, also see http://water. usgs.gov/osw/streamstats/bcdefinitionsl.html.

U.S. Geological Survey and U.S. Department of Agriculture, Natural Resources Conservation Service, 2009, Federal guidelines, requirements, and procedures for the National Watershed Boundary Dataset: U.S. Geological Survey Techniques and Methods 11-A3, $55 \mathrm{p}$. (Also available at $h t t p: / /$ pubs.usgs.gov/tm/tm11a3/, also see http://datagateway.nrcs. usda.gov/).

Wahl, K.L., and Wahl, T.L., 1988, Effects of regional groundwater level declines on streamflow in the Oklahoma Panhandle, in Proceedings of the Symposium on Water-Use Data for Water Resources Management: American Water Resources Association, August 1988, Tucson, Ariz., p. 239-249, accessed April 7, 2011, at http://www.usbr.gov/ pmts/hydraulics_lab/twahl/bfi/bfi_beaver_river.pdf.

Wahl, K.L., and Wahl, T.L., 1995, Determining the flow of Comal Springs at New Braunfels, Texas: Texas Water '95, American Society of Civil Engineers Symposium, August 16-17, 1995, San Antonio, Texas, p. 77-86, accessed April 7, 2011, at http://www.usbr.gov/pmts/ hydraulics_lab/pubs/PAP/PAP-0708.pdf. 


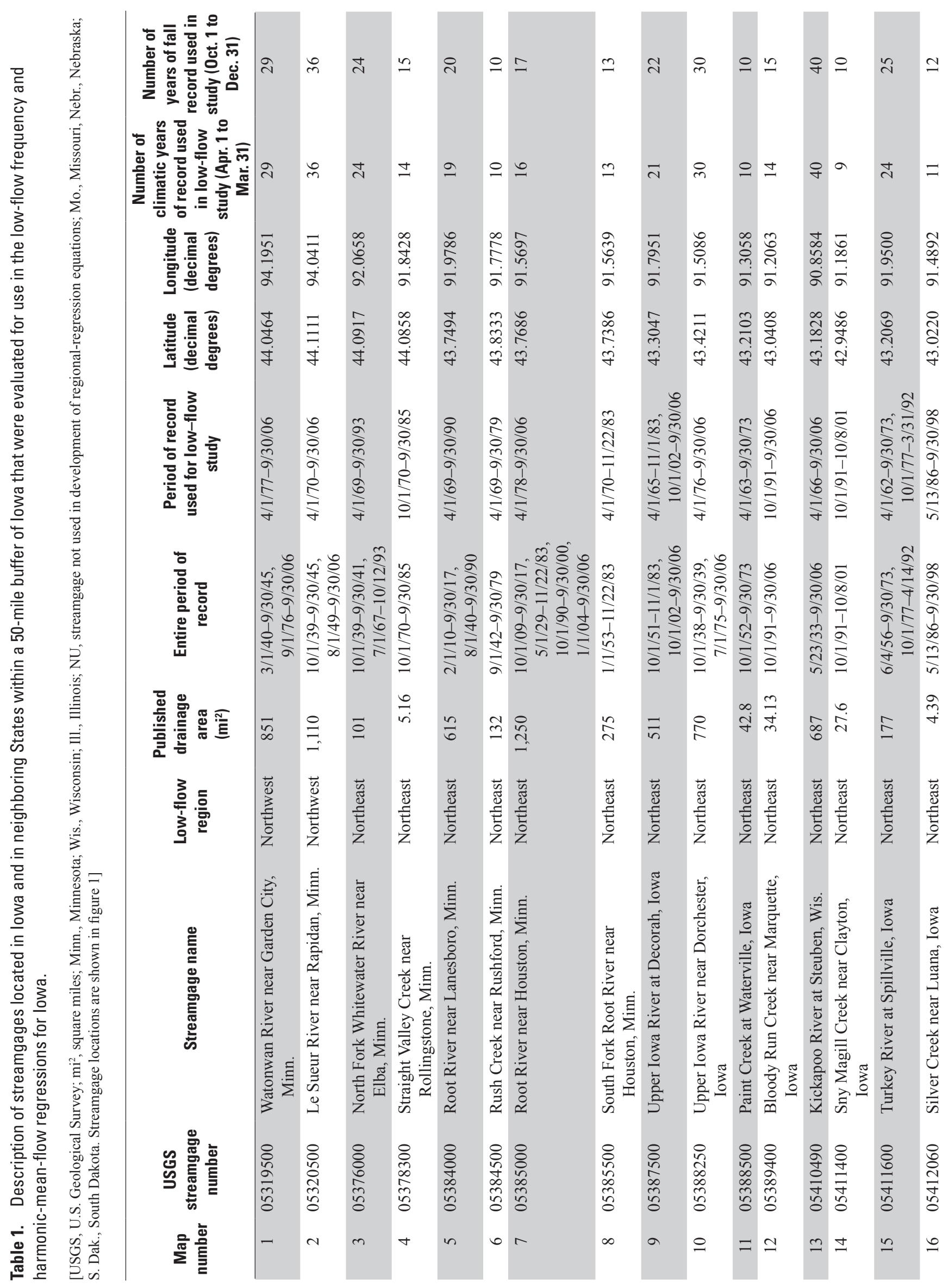




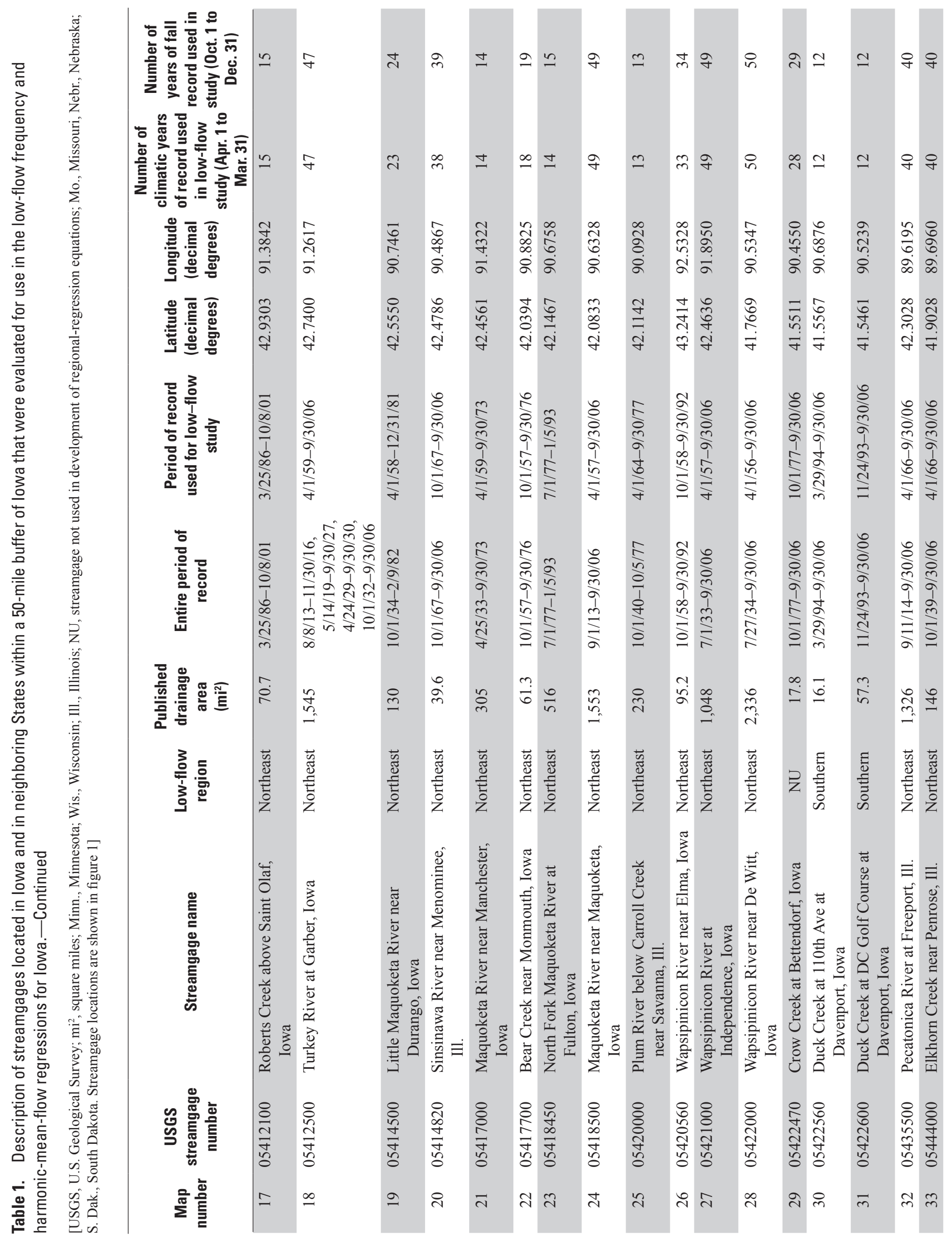


Tables

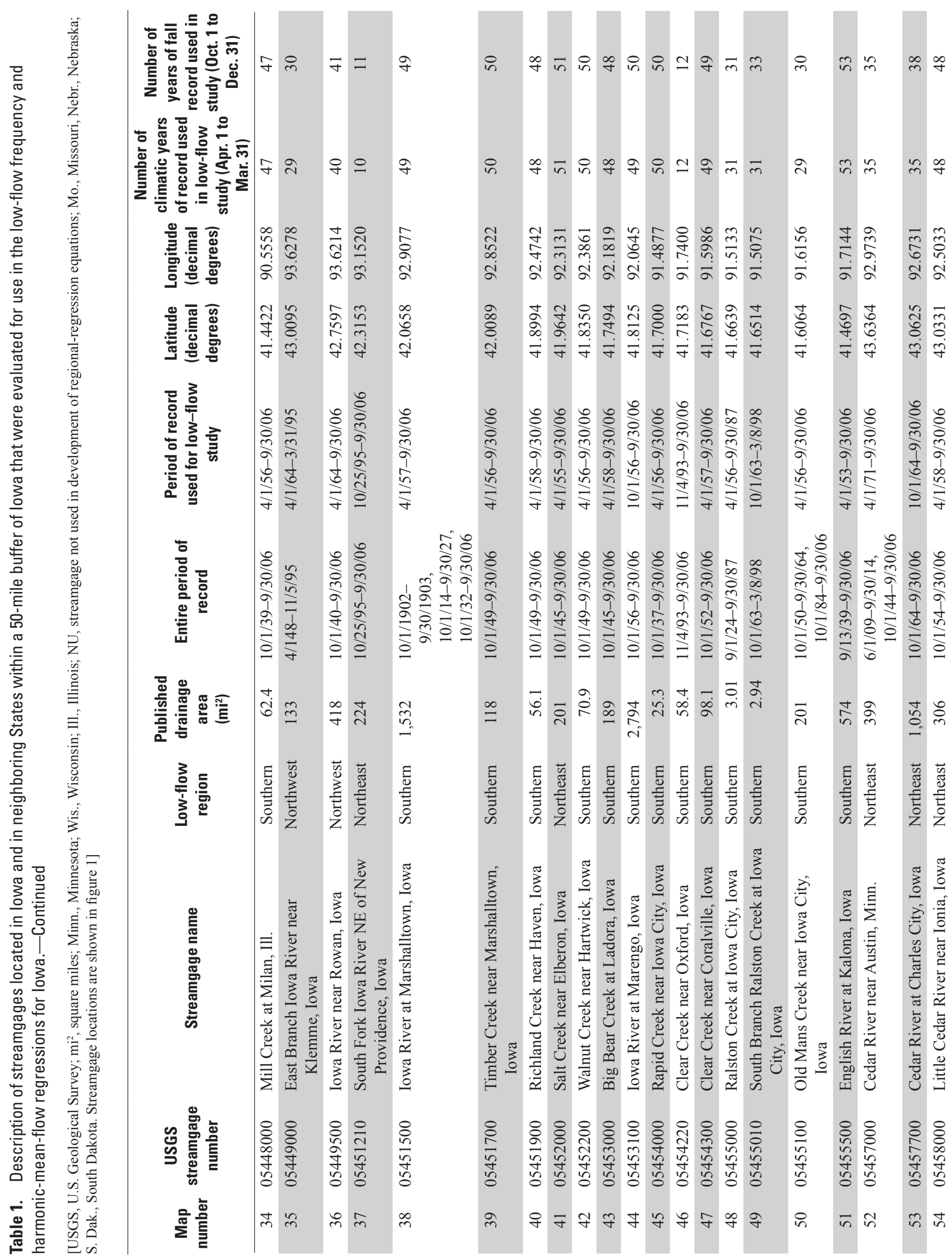




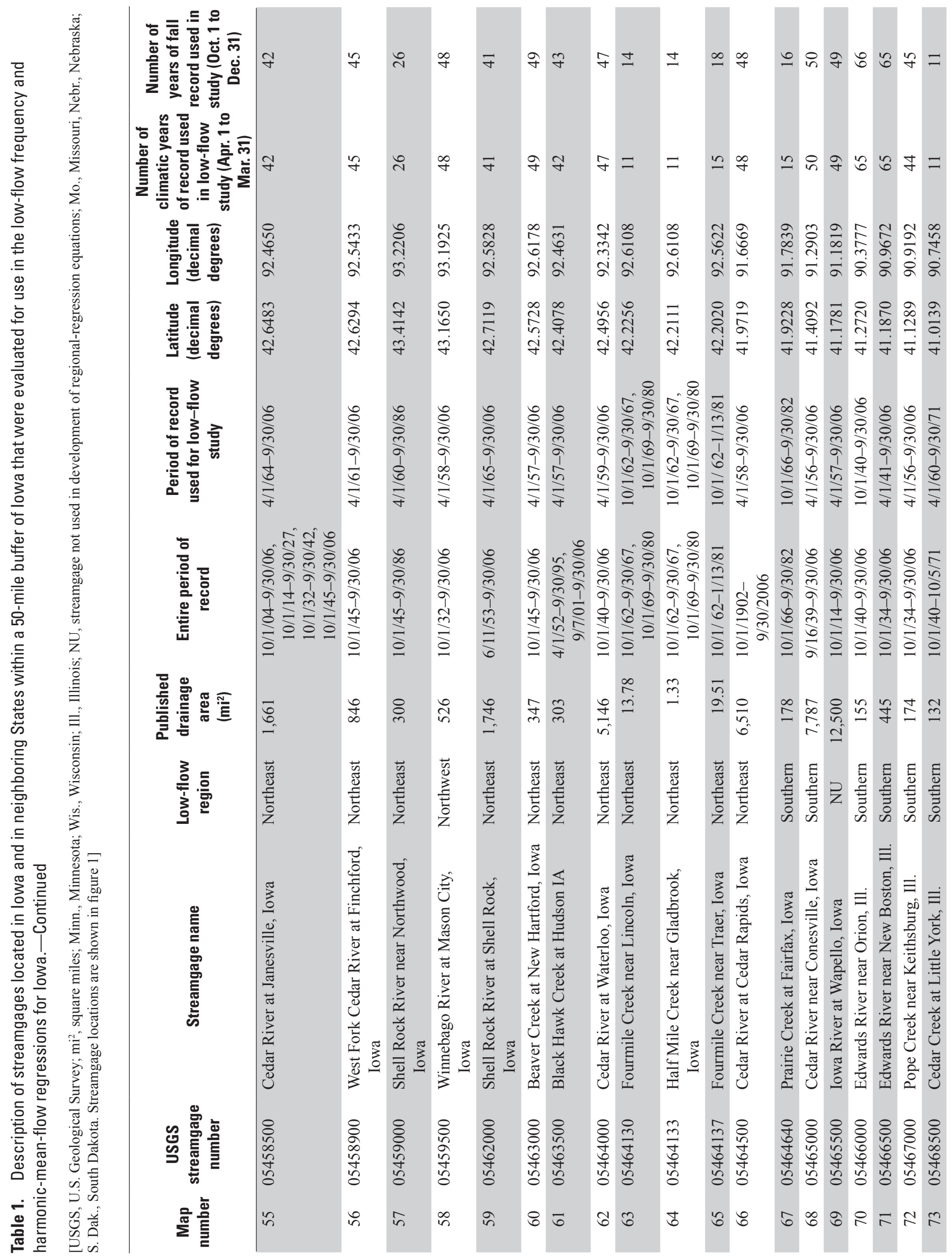




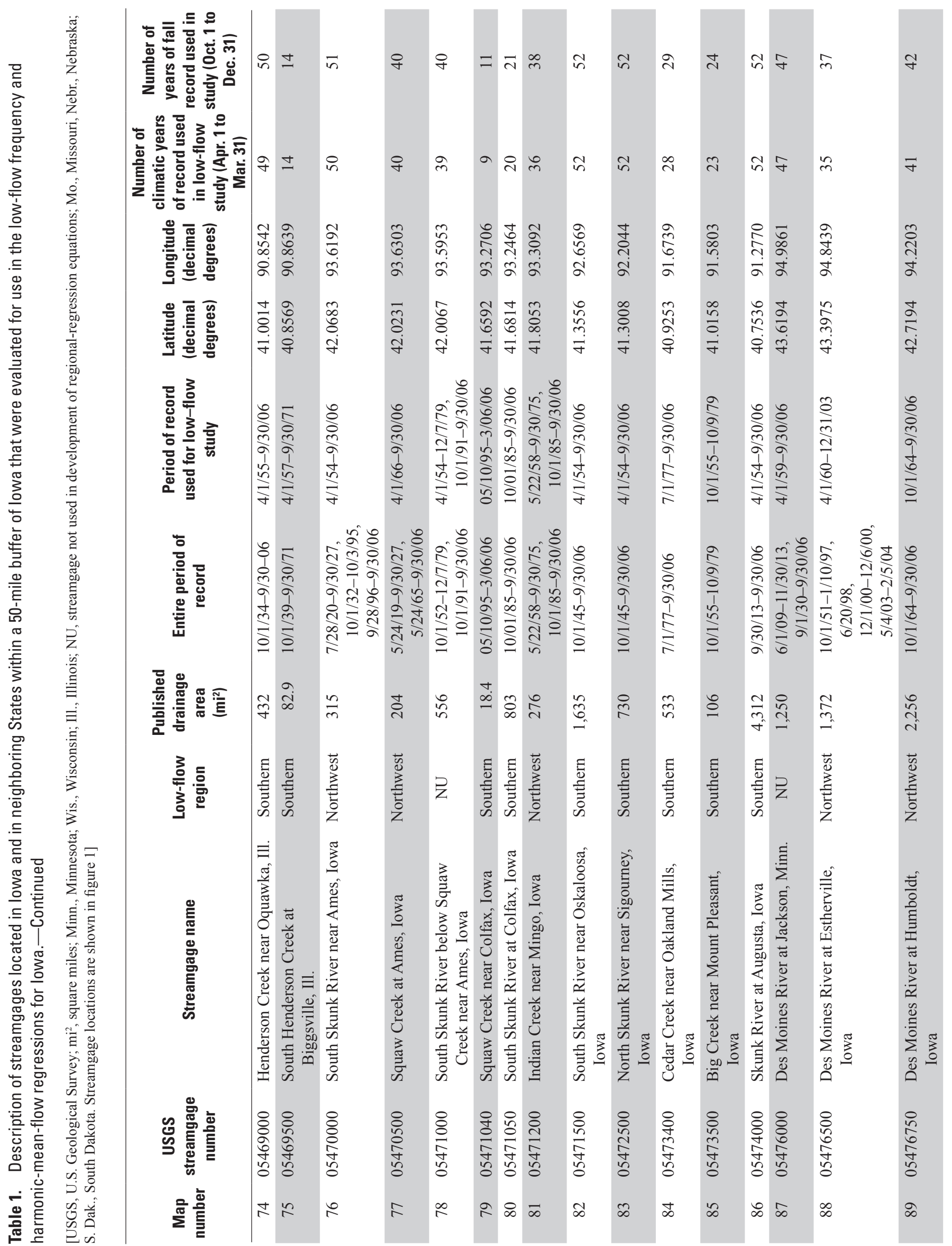




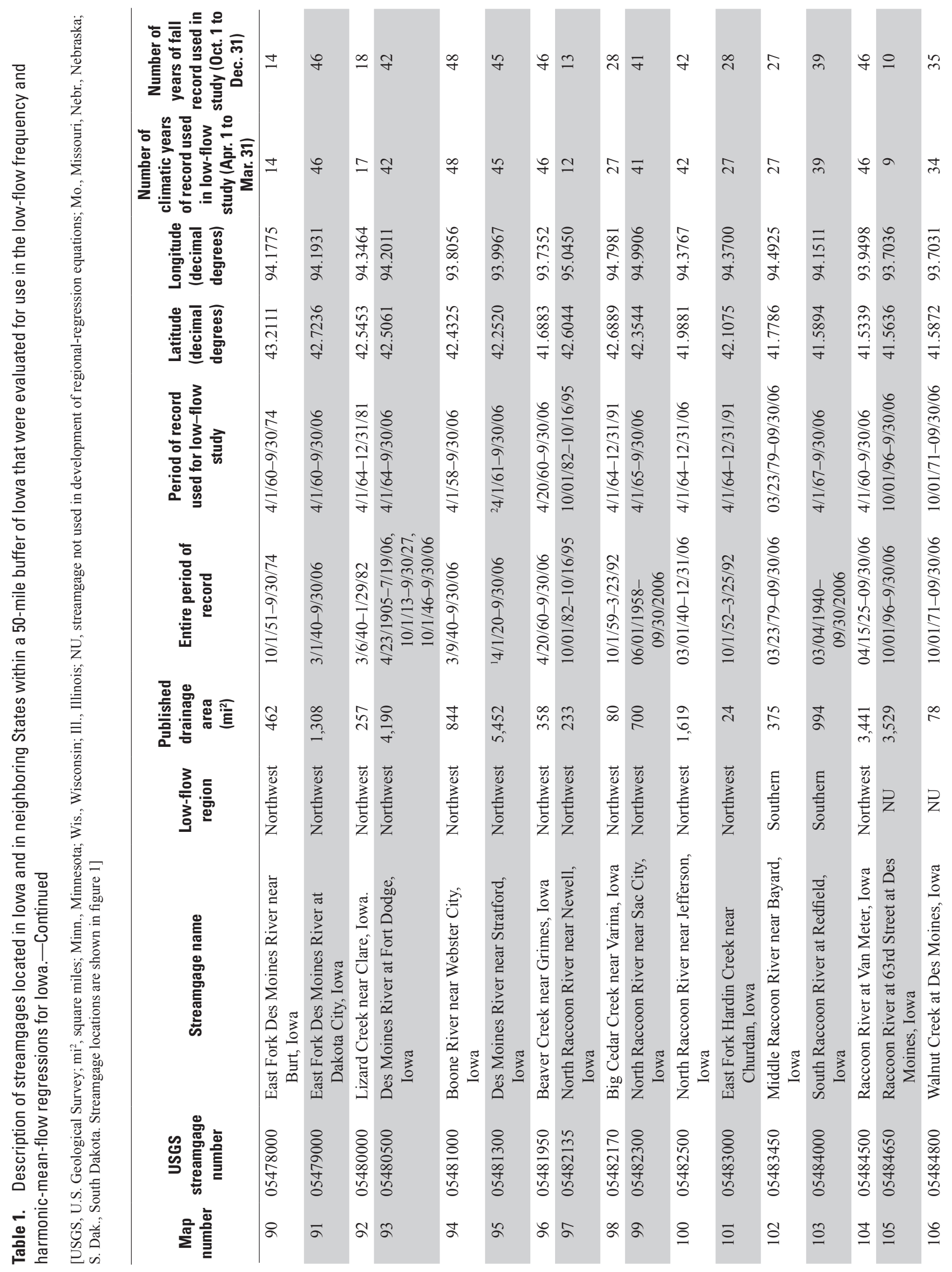




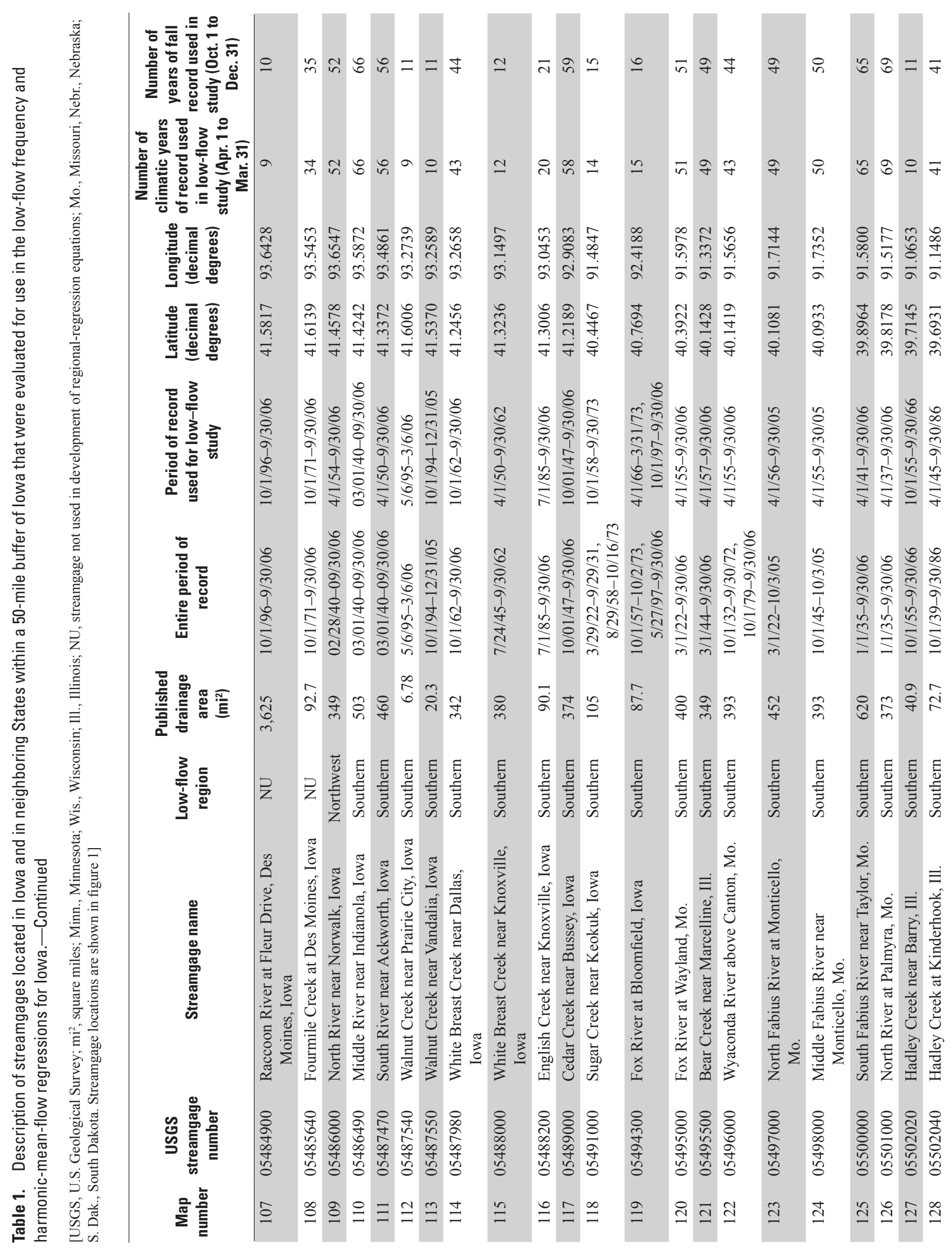




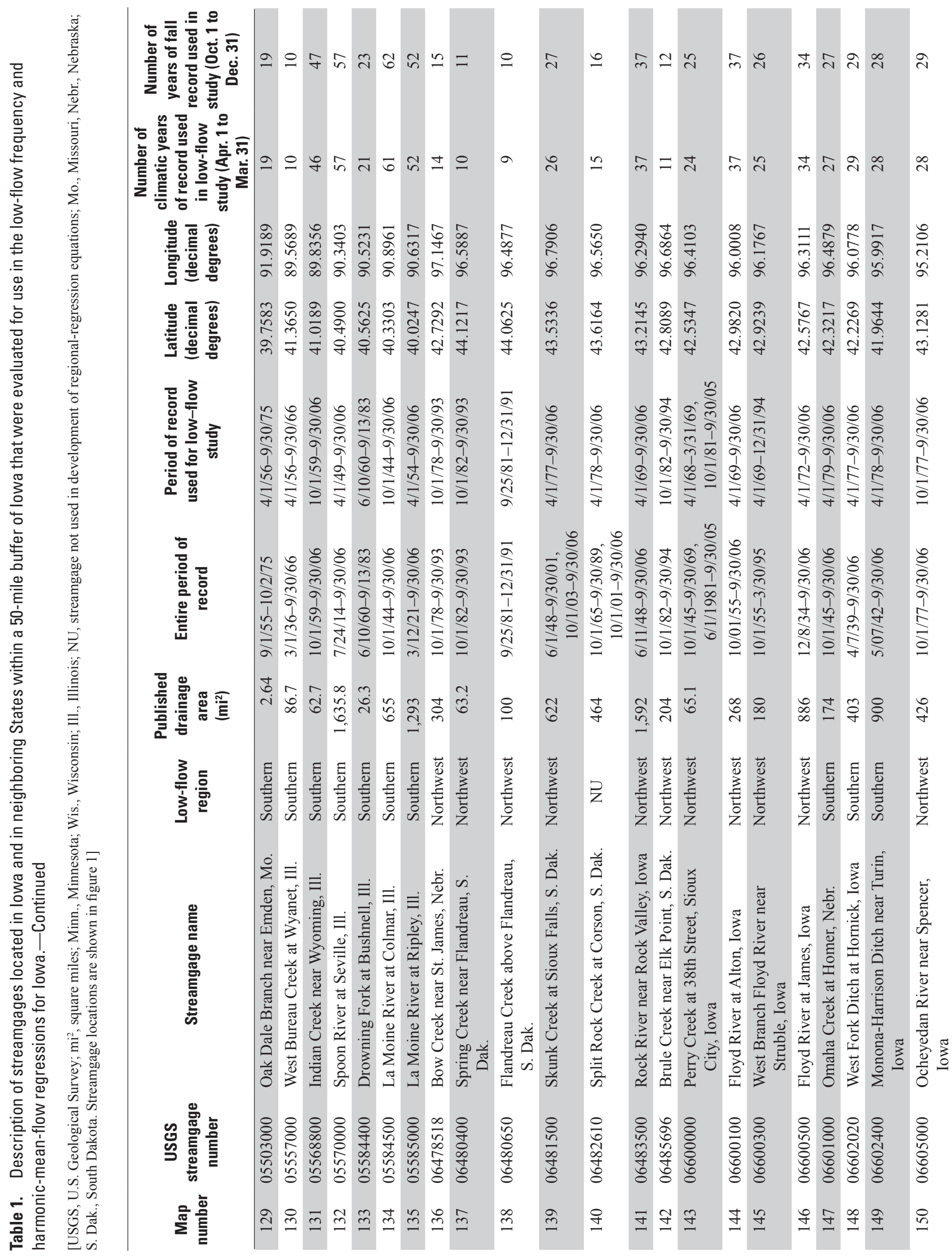


Tables $\quad 59$

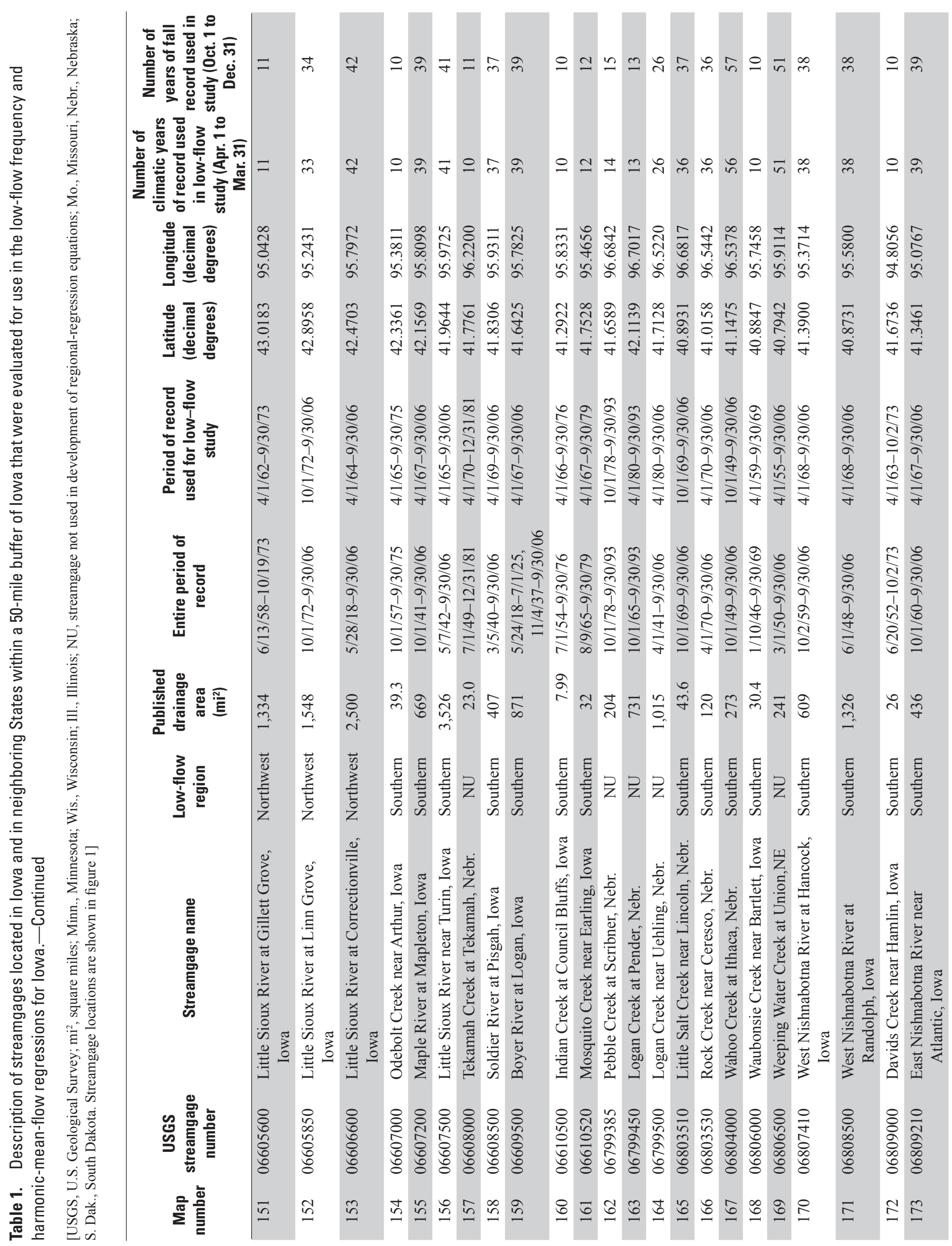




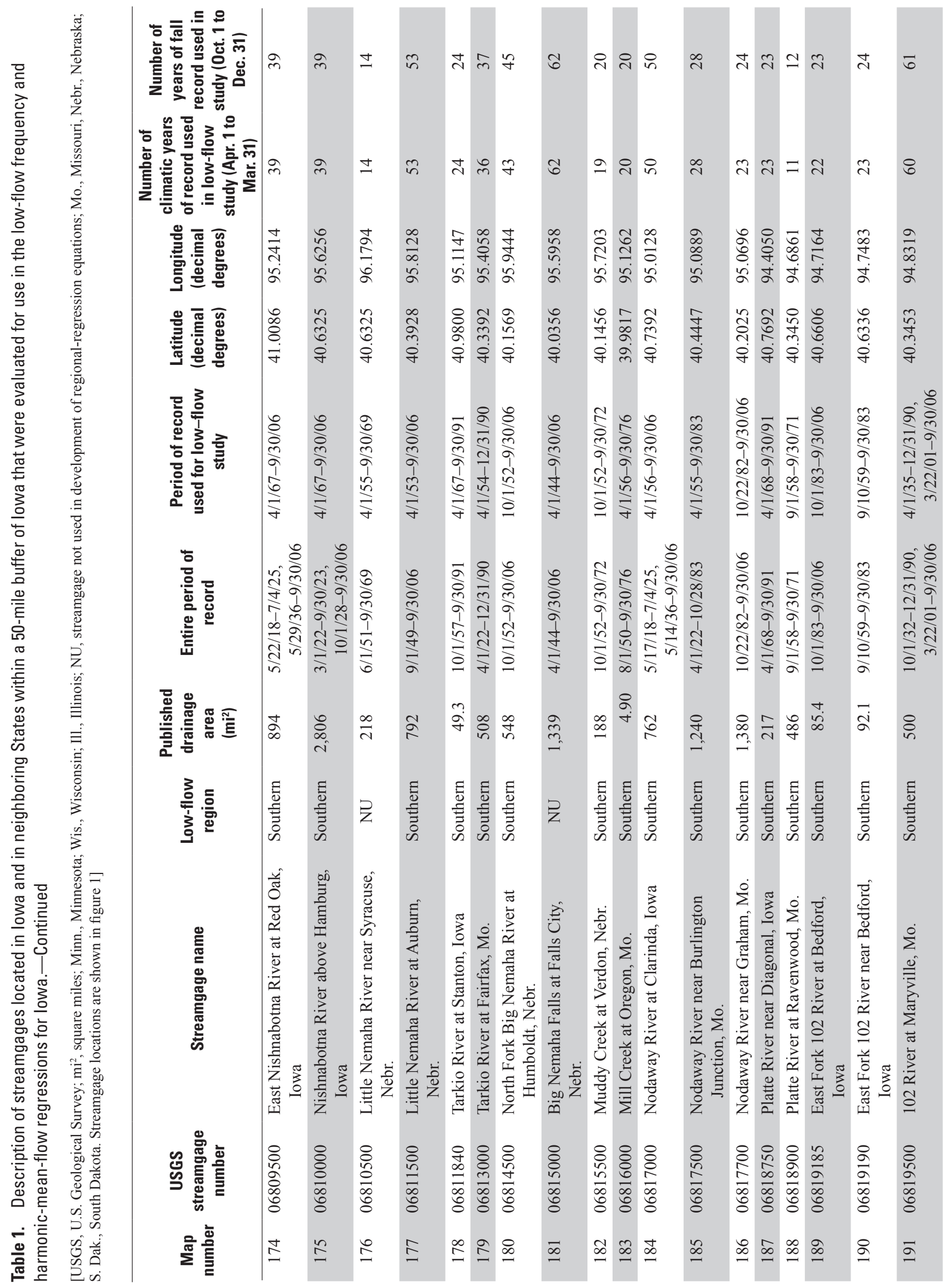




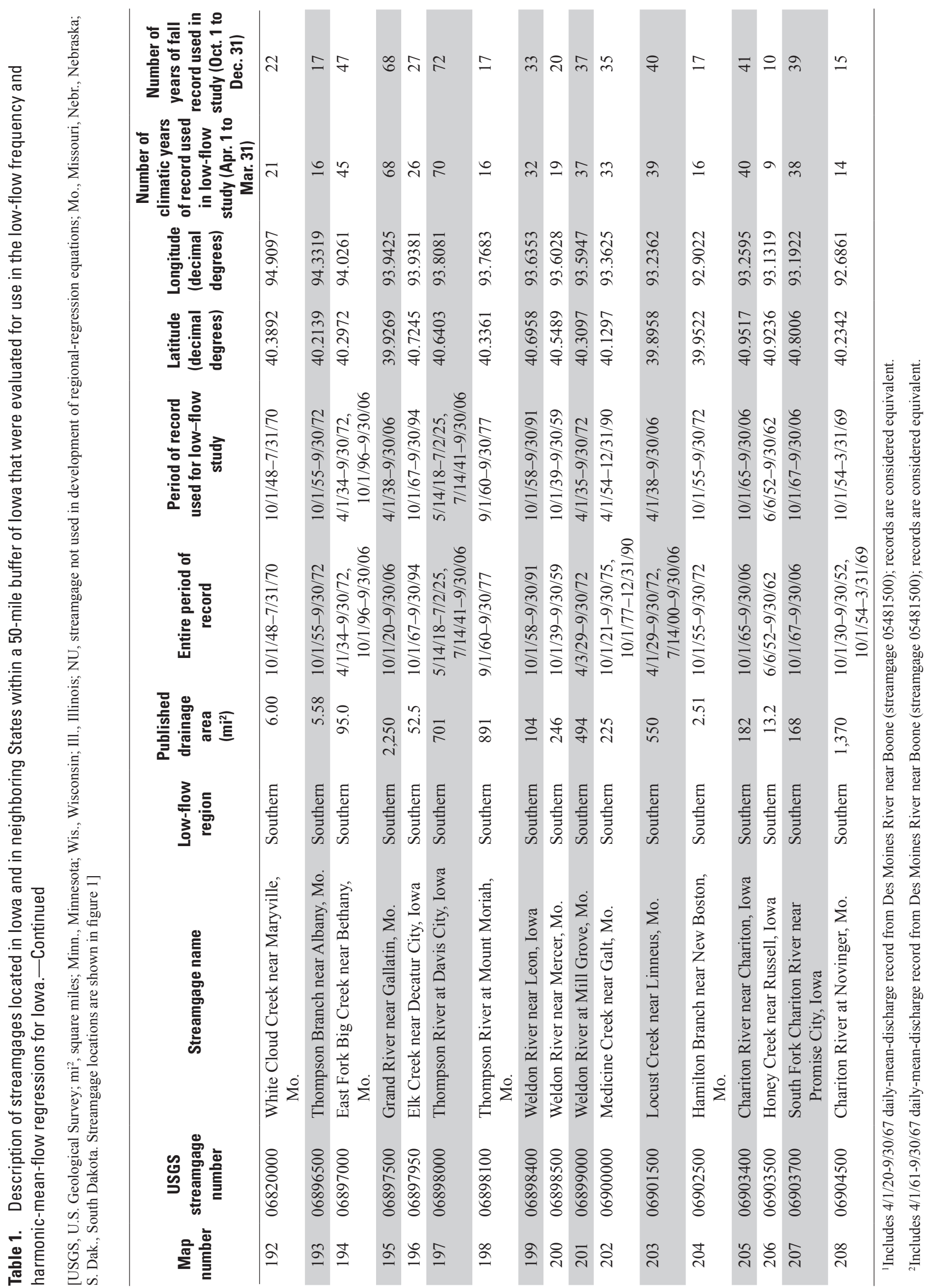


Table 2. Selected low-flow frequency statistics and harmonic mean flows computed from observed streamflow and predicted from regional regression equations for streamgages evaluated in study.

[USGS, U.S. Geological Survey; $\mathrm{mi}^{2}$, square miles; M1D10Y, annual 1-day mean low flow for a recurrence interval of 10 years; $\mathrm{ft}^{3} / \mathrm{s}$, cubic feet per second; M7D10Y, annual 7-day mean low flow for a recurrence interval of 10 years; M30D10Y, annual 30-day mean low flow for a recurrence interval of 10 years; M30D5Y, annual 30-day mean low flow for a recurrence interval of 5 years; M1D10Y1012, seasonal (October through December) 1-day mean low flow for a recurrence interval of 10 years; M7D10Y1012, seasonal (October through December) 7-day mean low flow for a recurrence interval of 10 years; QAH, harmonic mean flow. Streamgage locations are shown in figure 1; NU, streamgage not used in development of regional-regression equations; <, less than]

\begin{tabular}{|c|c|c|c|c|c|c|c|c|}
\hline $\begin{array}{c}\text { Map } \\
\text { number }\end{array}$ & $\begin{array}{c}\text { USGS } \\
\text { streamgage } \\
\text { number }\end{array}$ & $\begin{array}{l}\text { Low-flow } \\
\text { region }\end{array}$ & $\begin{array}{c}\text { Published } \\
\text { drainage area } \\
\left(\mathbf{m i}^{2}\right)\end{array}$ & $\begin{array}{c}\text { Observed } \\
\text { M1D10Y } \\
\left(\mathrm{ft}^{3} / \mathrm{s}\right)\end{array}$ & $\begin{array}{c}\text { Predicted } \\
\text { M1D10Y } \\
\left(\mathrm{ft}^{3} / \mathrm{s}\right)\end{array}$ & $\begin{array}{c}\text { Observed } \\
\text { M7D10Y } \\
\left(\mathrm{ft}^{3} / \mathrm{s}\right)\end{array}$ & $\begin{array}{c}\text { Predicted } \\
\text { M7D10Y } \\
\left(\mathrm{ft}^{3} / \mathrm{s}\right)\end{array}$ & $\begin{array}{c}\text { Observed } \\
\text { M30D10Y } \\
\left(\mathrm{ft}^{3} / \mathrm{s}\right)\end{array}$ \\
\hline 1 & 05319500 & Northwest & 851 & 5.37 & 1.59 & 5.78 & 2.05 & 7.31 \\
\hline 2 & 05320500 & Northwest & 1,110 & 10.5 & 10.6 & 11.0 & 12.1 & 13.2 \\
\hline 3 & 05376000 & Northeast & 101 & 14.8 & 23.5 & 17.5 & 25.0 & 18.8 \\
\hline 4 & 05378300 & Northeast & 5.16 & .70 & .93 & .77 & .96 & .93 \\
\hline 5 & 05384000 & Northeast & 615 & 80.9 & 79.4 & 85.3 & 88.0 & 89.4 \\
\hline 6 & 05384500 & Northeast & 132 & 27.7 & 27.0 & 28.8 & 29.0 & 31.3 \\
\hline 7 & 05385000 & Northeast & 1,250 & 297 & 241 & 305 & 267 & 338 \\
\hline 8 & 05385500 & Northeast & 275 & 68.5 & 47.7 & 71.7 & 51.6 & 74.3 \\
\hline 9 & 05387500 & Northeast & 511 & 39.7 & 50.4 & 44.7 & 56.8 & 52.0 \\
\hline 10 & 05388250 & Northeast & 770 & 79.8 & 83.9 & 90.2 & 94.8 & 105 \\
\hline 11 & 05388500 & Northeast & 42.8 & 1.50 & 2.68 & 1.62 & 2.89 & 1.71 \\
\hline 12 & 05389400 & Northeast & 34.13 & 6.87 & 2.00 & 7.58 & 2.19 & 8.27 \\
\hline 13 & 05410490 & Northeast & 687 & 238 & 283 & 248 & 311 & 270 \\
\hline 14 & 05411400 & Northeast & 27.6 & 5.18 & NU & 5.75 & NU & 6.88 \\
\hline 15 & 05411600 & Northeast & 177 & 8.44 & 13.5 & 9.12 & 15.3 & 10.9 \\
\hline 16 & 05412060 & Northeast & 4.39 & .01 & $<.1$ & .01 & $<.1$ & .03 \\
\hline 17 & 05412100 & Northeast & 70.7 & .00 & 1.41 & .01 & 1.55 & .04 \\
\hline 18 & 05412500 & Northeast & 1,545 & 104 & 139 & 115 & 160 & 136 \\
\hline 19 & 05414500 & Northeast & 130 & 6.42 & 5.70 & 7.59 & 6.32 & 9.82 \\
\hline 20 & 05414820 & Northeast & 39.6 & 6.37 & 1.65 & 7.05 & 1.76 & 8.04 \\
\hline 21 & 05417000 & Northeast & 305 & 27.0 & 14.5 & 34.6 & 16.6 & 40.1 \\
\hline 22 & 05417700 & Northeast & 61.3 & 2.27 & .52 & 2.78 & .58 & 3.53 \\
\hline 23 & 05418450 & Northeast & 516 & 62.6 & 33.5 & 68.0 & 37.7 & 85.3 \\
\hline 24 & 05418500 & Northeast & 1,553 & 162 & 106 & 189 & 123 & 221 \\
\hline 25 & 05420000 & Northeast & 230 & 11.0 & 14.0 & 11.8 & 15.1 & 14.4 \\
\hline 26 & 05420560 & Northeast & 95.2 & 3.42 & 3.02 & 3.85 & 3.38 & 4.46 \\
\hline 27 & 05421000 & Northeast & 1,048 & 26.5 & 62.7 & 27.9 & 72.4 & 34.5 \\
\hline 28 & 05422000 & Northeast & 2,336 & 124 & 129 & 132 & 150 & 152 \\
\hline 29 & 05422470 & $\mathrm{NU}$ & 17.8 & .20 & $\mathrm{NU}$ & .28 & $\mathrm{NU}$ & .56 \\
\hline 30 & 05422560 & Southern & 16.1 & .08 & .00 & .09 & .00 & .18 \\
\hline 31 & 05422600 & Southern & 57.3 & .38 & .56 & .77 & .70 & 1.63 \\
\hline 32 & 05435500 & Northeast & 1,326 & 256 & 325 & 271 & 354 & 297 \\
\hline 33 & 05444000 & Northeast & 146 & 19.5 & 9.71 & 21.2 & 10.5 & 23.7 \\
\hline 34 & 05448000 & Southern & 62.4 & .15 & .59 & .24 & .74 & .41 \\
\hline 35 & 05449000 & Northwest & 133 & .74 & .44 & .89 & .54 & .94 \\
\hline 36 & 05449500 & Northwest & 418 & 10.0 & 2.58 & 11.1 & 3.04 & 13.5 \\
\hline 37 & 05451210 & Northeast & 224 & 1.68 & 1.36 & 2.02 & 1.54 & 2.88 \\
\hline
\end{tabular}


Table 2. Selected low-flow frequency statistics and harmonic mean flows computed from observed streamflow and predicted from regional regression equations for streamgages evaluated in study.-Continued

[USGS, U.S. Geological Survey; $\mathrm{mi}^{2}$, square miles; M1D10Y, annual 1-day mean low flow for a recurrence interval of 10 years; $\mathrm{ft}^{3} / \mathrm{s}$, cubic feet per second; M7D10Y, annual 7-day mean low flow for a recurrence interval of 10 years; M30D10Y, annual 30-day mean low flow for a recurrence interval of 10 years; M30D5Y, annual 30-day mean low flow for a recurrence interval of 5 years; M1D10Y1012, seasonal (October through December) 1-day mean low flow for a recurrence interval of 10 years; M7D10Y1012, seasonal (October through December) 7-day mean low flow for a recurrence interval of 10 years; QAH, harmonic mean flow. Streamgage locations are shown in figure 1; NU, streamgage not used in development of regional-regression equations; <, less than]

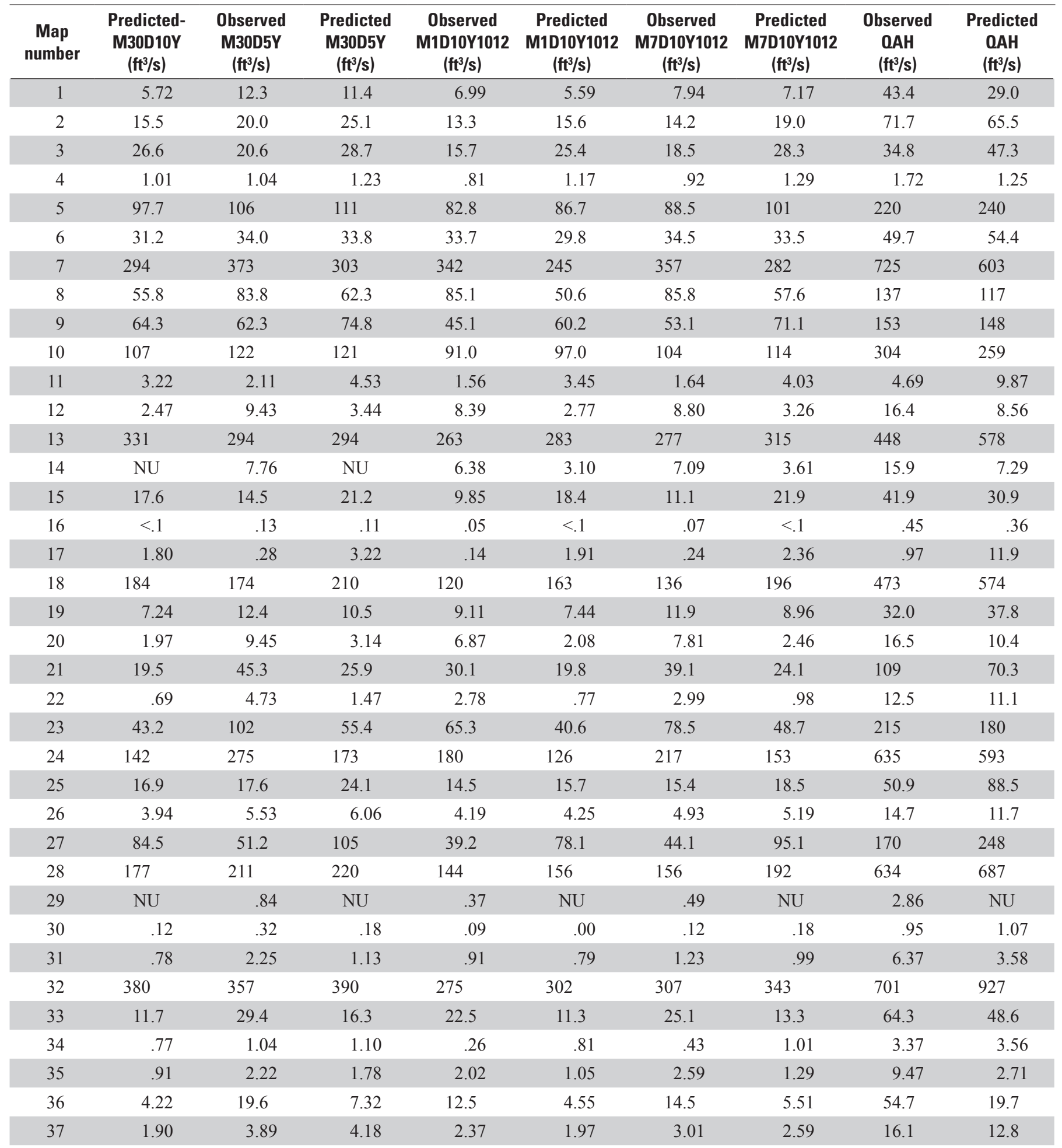


Table 2. Selected low-flow frequency statistics and harmonic mean flows computed from observed streamflow and predicted from regional regression equations for streamgages evaluated in study.-Continued

[USGS, U.S. Geological Survey; $\mathrm{mi}^{2}$, square miles; M1D10Y, annual 1-day mean low flow for a recurrence interval of 10 years; $\mathrm{ft}^{3} / \mathrm{s}$, cubic feet per second; M7D10Y, annual 7-day mean low flow for a recurrence interval of 10 years; M30D10Y, annual 30-day mean low flow for a recurrence interval of 10 years; M30D5Y, annual 30-day mean low flow for a recurrence interval of 5 years; M1D10Y1012, seasonal (October through December) 1-day mean low flow for a recurrence interval of 10 years; M7D10Y1012, seasonal (October through December) 7-day mean low flow for a recurrence interval of 10 years; QAH, harmonic mean flow. Streamgage locations are shown in figure 1; NU, streamgage not used in development of regional-regression equations; <, less than]

\begin{tabular}{|c|c|c|c|c|c|c|c|c|}
\hline $\begin{array}{c}\text { Map } \\
\text { number }\end{array}$ & $\begin{array}{c}\text { USGS } \\
\text { streamgage } \\
\text { number }\end{array}$ & $\begin{array}{l}\text { Low-flow } \\
\text { region }\end{array}$ & $\begin{array}{c}\text { Published } \\
\text { drainage area } \\
\left(\mathrm{mi}^{2}\right)\end{array}$ & $\begin{array}{c}\text { Observed } \\
\text { M1D10Y } \\
\left(\mathrm{ft}^{3} / \mathrm{s}\right)\end{array}$ & $\begin{array}{c}\text { Predicted } \\
\text { M1D10Y } \\
\left(\mathrm{ft}^{3} / \mathbf{s}\right)\end{array}$ & $\begin{array}{c}\text { Observed } \\
\text { M7D10Y } \\
\left(\mathrm{ft}^{3} / \mathrm{s}\right)\end{array}$ & $\begin{array}{c}\text { Predicted } \\
\text { M7D10Y } \\
\left(\mathrm{ft}^{3} / \mathbf{s}\right)\end{array}$ & $\begin{array}{c}\text { Observed } \\
\text { M30D10Y } \\
\left(\mathrm{ft}^{3} / \mathrm{s}\right)\end{array}$ \\
\hline 38 & 05451500 & Southern & 1,532 & 29.9 & 34.6 & 33.9 & 44.0 & 44.6 \\
\hline 39 & 05451700 & Southern & 118 & .20 & 1.03 & .66 & 1.28 & 1.07 \\
\hline 40 & 05451900 & Southern & 56.1 & .18 & .32 & .38 & .40 & .65 \\
\hline 41 & 05452000 & Northeast & 201 & 3.14 & 2.11 & 3.63 & 2.36 & 4.78 \\
\hline 42 & 05452200 & Southern & 70.9 & .20 & .40 & .28 & .50 & .34 \\
\hline 43 & 05453000 & Southern & 189 & 1.67 & 1.01 & 1.75 & 1.23 & 2.60 \\
\hline 44 & 05453100 & Southern & 2,794 & 82.5 & 75.2 & 86.6 & 96.1 & 103 \\
\hline 45 & 05454000 & Southern & 25.3 & .00 & .00 & .00 & .00 & .00 \\
\hline 46 & 05454220 & Southern & 58.4 & .60 & .35 & .69 & .43 & .94 \\
\hline 47 & 05454300 & Southern & 98.1 & .88 & .66 & 1.00 & .81 & 1.45 \\
\hline 48 & 05455000 & Southern & 3.01 & .00 & .00 & .00 & .00 & .00 \\
\hline 49 & 05455010 & Southern & 2.94 & .00 & .00 & .00 & .00 & .00 \\
\hline 50 & 05455100 & Southern & 201 & .67 & 1.68 & .77 & 2.08 & 1.20 \\
\hline 51 & 05455500 & Southern & 574 & 2.05 & 4.58 & 2.77 & 5.70 & 4.25 \\
\hline 52 & 05457000 & Northeast & 399 & 38.9 & 29.8 & 42.3 & 33.7 & 46.0 \\
\hline 53 & 05457700 & Northeast & 1,054 & 82.1 & 77.5 & 94.4 & 88.8 & 110 \\
\hline 54 & 05458000 & Northeast & 306 & 7.25 & 11.1 & 7.79 & 12.6 & 9.02 \\
\hline 55 & 05458500 & Northeast & 1,661 & 125 & 119 & 141 & 137 & 159 \\
\hline 56 & 05458900 & Northeast & 846 & 24.9 & 21.7 & 27.5 & 25.3 & 32.8 \\
\hline 57 & 05459000 & Northeast & 300 & 5.00 & 8.32 & 5.20 & 9.47 & 6.60 \\
\hline 58 & 05459500 & Northwest & 526 & 8.45 & 6.86 & 11.2 & 8.04 & 14.4 \\
\hline 59 & 05462000 & Northeast & 1,746 & 70.4 & 71.5 & 84.9 & 83.5 & 107 \\
\hline 60 & 05463000 & Northeast & 347 & 6.10 & 5.13 & 6.81 & 5.86 & 8.54 \\
\hline 61 & 05463500 & Northeast & 303 & 3.33 & 4.64 & 4.04 & 5.28 & 6.53 \\
\hline 62 & 05464000 & Northeast & 5,146 & 355 & 342 & 398 & 403 & 448 \\
\hline 63 & 05464130 & Northeast & 13.78 & .06 & $<.1$ & .07 & $<.1$ & .09 \\
\hline 64 & 05464133 & Northeast & 1.33 & .00 & $<.1$ & .00 & $<.1$ & .00 \\
\hline 65 & 05464137 & Northeast & 19.51 & .00 & .10 & .00 & .11 & .05 \\
\hline 66 & 05464500 & Northeast & 6,510 & 329 & 385 & 440 & 456 & 504 \\
\hline 67 & 05464640 & Southern & 178 & .50 & 2.59 & .87 & 3.27 & 1.35 \\
\hline 68 & 05465000 & Southern & 7,787 & 484 & 459 & 575 & 606 & 660 \\
\hline 69 & 05465500 & NU & 12,500 & 797 & $\mathrm{NU}$ & 907 & $\mathrm{NU}$ & 1,020 \\
\hline 70 & 05466000 & Southern & 155 & 1.30 & 1.37 & 1.51 & 1.68 & 2.14 \\
\hline 71 & 05466500 & Southern & 445 & 6.47 & 6.61 & 7.40 & 8.28 & 9.75 \\
\hline 72 & 05467000 & Southern & 174 & 2.25 & 1.87 & 2.75 & 2.33 & 3.52 \\
\hline 73 & 05468500 & Southern & 132 & 5.99 & 1.14 & 6.91 & 1.41 & 9.01 \\
\hline 74 & 05469000 & Southern & 432 & .00 & 6.77 & .00 & 8.50 & .00 \\
\hline 75 & 05469500 & Southern & 82.9 & .00 & .47 & .00 & .57 & .00 \\
\hline
\end{tabular}


Table 2. Selected low-flow frequency statistics and harmonic mean flows computed from observed streamflow and predicted from regional regression equations for streamgages evaluated in study.-Continued

[USGS, U.S. Geological Survey; $\mathrm{mi}^{2}$, square miles; M1D10Y, annual 1-day mean low flow for a recurrence interval of 10 years; $\mathrm{ft}^{3} / \mathrm{s}$, cubic feet per second; M7D10Y, annual 7-day mean low flow for a recurrence interval of 10 years; M30D10Y, annual 30-day mean low flow for a recurrence interval of 10 years; M30D5Y, annual 30-day mean low flow for a recurrence interval of 5 years; M1D10Y1012, seasonal (October through December) 1-day mean low flow for a recurrence interval of 10 years; M7D10Y1012, seasonal (October through December) 7-day mean low flow for a recurrence interval of 10 years; QAH, harmonic mean flow. Streamgage locations are shown in figure 1; NU, streamgage not used in development of regional-regression equations; <, less than]

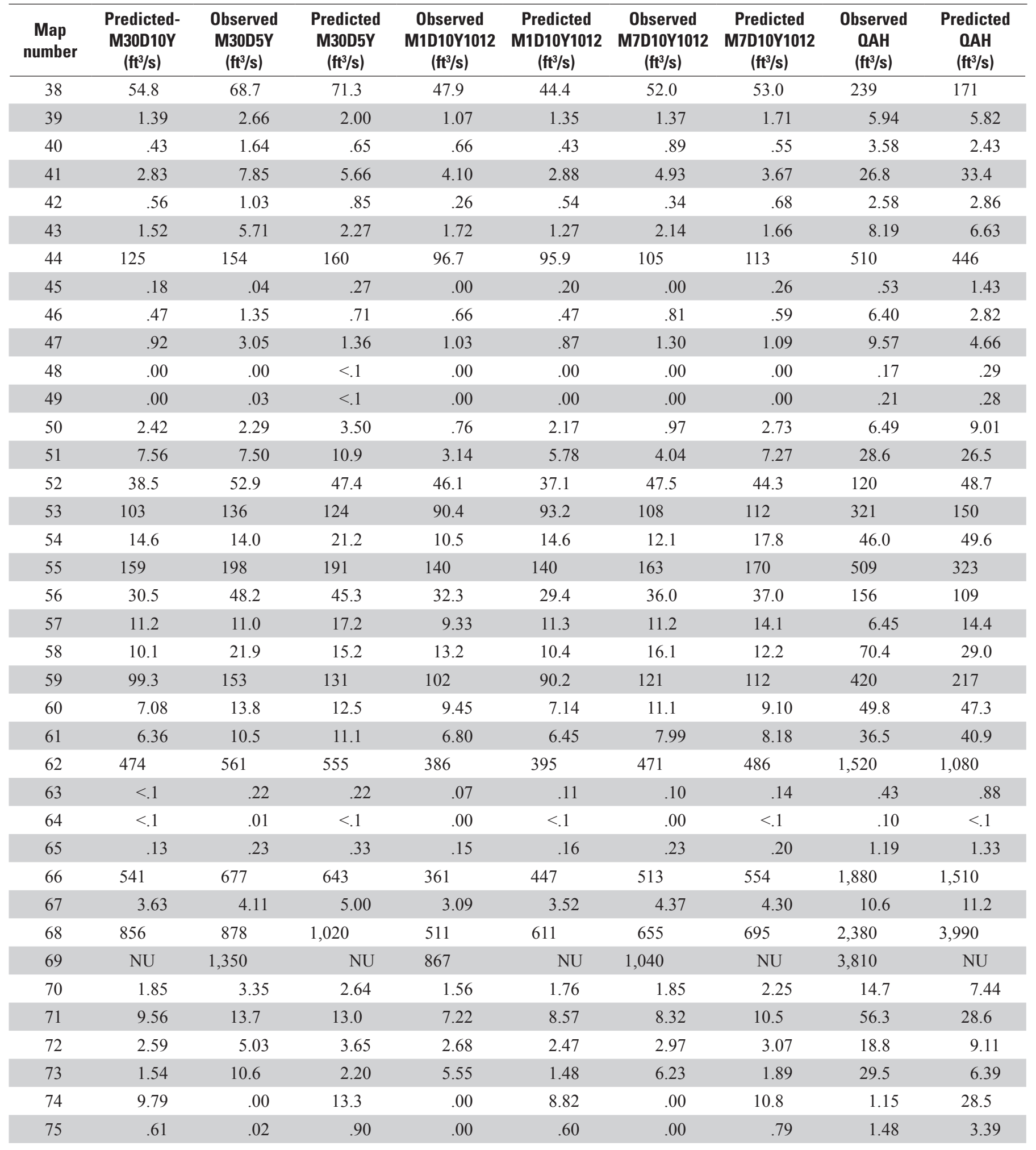


Table 2. Selected low-flow frequency statistics and harmonic mean flows computed from observed streamflow and predicted from regional regression equations for streamgages evaluated in study.-Continued

[USGS, U.S. Geological Survey; $\mathrm{mi}^{2}$, square miles; M1D10Y, annual 1-day mean low flow for a recurrence interval of 10 years; $\mathrm{ft}^{3} / \mathrm{s}$, cubic feet per second; M7D10Y, annual 7-day mean low flow for a recurrence interval of 10 years; M30D10Y, annual 30-day mean low flow for a recurrence interval of 10 years; M30D5Y, annual 30-day mean low flow for a recurrence interval of 5 years; M1D10Y1012, seasonal (October through December) 1-day mean low flow for a recurrence interval of 10 years; M7D10Y1012, seasonal (October through December) 7-day mean low flow for a recurrence interval of 10 years; QAH, harmonic mean flow. Streamgage locations are shown in figure 1; NU, streamgage not used in development of regional-regression equations; $<$, less than]

\begin{tabular}{|c|c|c|c|c|c|c|c|c|}
\hline $\begin{array}{c}\text { Map } \\
\text { number }\end{array}$ & $\begin{array}{c}\text { USGS } \\
\text { streamgage } \\
\text { number }\end{array}$ & $\begin{array}{l}\text { Low-flow } \\
\text { region }\end{array}$ & $\begin{array}{c}\text { Published } \\
\text { drainage area } \\
\left(\mathrm{mi}^{2}\right)\end{array}$ & $\begin{array}{c}\text { Observed } \\
\text { M1D10Y } \\
\left(\mathrm{ft}^{3} / \mathbf{s}\right)\end{array}$ & $\begin{array}{c}\text { Predicted } \\
\text { M1D10Y } \\
\left(\mathrm{ft}^{3} / \mathrm{s}\right)\end{array}$ & $\begin{array}{c}\text { Observed } \\
\text { M7D10Y } \\
\left(\mathrm{ft}^{3} / \mathrm{s}\right)\end{array}$ & $\begin{array}{c}\text { Predicted } \\
\text { M7D10Y } \\
\left(\mathrm{ft}^{3} / \mathbf{s}\right)\end{array}$ & $\begin{array}{c}\text { Observed } \\
\text { M30D10Y } \\
\left(\mathrm{ft}^{3} / \mathrm{s}\right)\end{array}$ \\
\hline 76 & 05470000 & Northwest & 315 & 0.07 & 0.15 & 0.11 & 0.20 & 0.21 \\
\hline 77 & 05470500 & Northwest & 204 & .00 & $<.1$ & .00 & $<.1$ & .15 \\
\hline 78 & 05471000 & $\mathrm{NU}$ & 556 & .00 & $\mathrm{NU}$ & .00 & $\mathrm{NU}$ & .00 \\
\hline 79 & 05471040 & Southern & 18.4 & .32 & $\mathrm{NU}$ & .42 & $\mathrm{NU}$ & .63 \\
\hline 80 & 05471050 & Southern & 803 & 9.14 & 9.73 & 12.2 & 12.1 & 16.6 \\
\hline 81 & 05471200 & Northwest & 276 & .35 & .11 & .64 & .15 & 1.60 \\
\hline 82 & 05471500 & Southern & 1,635 & 14.1 & 23.6 & 15.4 & 29.4 & 20.9 \\
\hline 83 & 05472500 & Southern & 730 & 3.76 & 5.90 & 4.39 & 7.28 & 5.99 \\
\hline 84 & 05473400 & Southern & 533 & 1.12 & 1.02 & 1.59 & 1.22 & 3.30 \\
\hline 85 & 05473500 & Southern & 106 & .00 & .27 & .00 & .33 & .01 \\
\hline 86 & 05474000 & Southern & 4,312 & 44.6 & 53.0 & 49.7 & 66.2 & 62.3 \\
\hline 87 & 05476000 & NU & 1,250 & .11 & $\mathrm{NU}$ & .35 & $\mathrm{NU}$ & 1.15 \\
\hline 88 & 05476500 & Northwest & 1,372 & 1.80 & 4.76 & 2.00 & 5.56 & 2.82 \\
\hline 89 & 05476750 & Northwest & 2,256 & 25.1 & 18.3 & 27.8 & 20.4 & 31.3 \\
\hline 90 & 05478000 & Northwest & 462 & .85 & 1.08 & .96 & 1.31 & 1.56 \\
\hline 91 & 05479000 & Northwest & 1,308 & 11.7 & 5.98 & 13.1 & 6.85 & 15.6 \\
\hline 92 & 05480000 & Northwest & 257 & .00 & .33 & .07 & .41 & .51 \\
\hline 93 & 05480500 & Northwest & 4,190 & 42.6 & 74.0 & 54.3 & 79.4 & 66.9 \\
\hline 94 & 05481000 & Northwest & 844 & 5.33 & 2.23 & 5.80 & 2.60 & 7.00 \\
\hline 95 & 05481300 & Northwest & 5,452 & 58.9 & 135 & 66.5 & 143 & 83.9 \\
\hline 96 & 05481950 & Northwest & 358 & .01 & .30 & .05 & .37 & .26 \\
\hline 97 & 05482135 & Northwest & 233 & .61 & .46 & .072 & .55 & 1.43 \\
\hline 98 & 05482170 & Northwest & 80 & .00 & $<.1$ & .00 & .10 & .00 \\
\hline 99 & 05482300 & Northwest & 700 & 4.65 & 2.72 & 4.80 & 3.08 & 6.15 \\
\hline 100 & 05482500 & Northwest & 1,619 & 12.9 & 10.3 & 14.2 & 11.4 & 20.1 \\
\hline 101 & 05483000 & Northwest & 24 & .00 & $<.1$ & .00 & $<.1$ & .00 \\
\hline 102 & 05483450 & Southern & 375 & 11.0 & 5.67 & 13.8 & 7.13 & 18.3 \\
\hline 103 & 05484000 & Southern & 994 & 30.7 & 18.5 & 36.0 & 23.5 & 44.4 \\
\hline 104 & 05484500 & Northwest & 3,441 & 64.7 & 26.0 & 77.5 & 28.9 & 94.7 \\
\hline 105 & 05484650 & $\mathrm{NU}$ & 3,529 & 93.6 & NU & 114 & $\mathrm{NU}$ & 137 \\
\hline 106 & 05484800 & $\mathrm{NU}$ & 78 & .00 & NU & .07 & $\mathrm{NU}$ & .96 \\
\hline 107 & 05484900 & $\mathrm{NU}$ & 3,625 & 56.1 & $\mathrm{NU}$ & 92.2 & $\mathrm{NU}$ & 106 \\
\hline 108 & 05485640 & $\mathrm{NU}$ & 92.7 & .22 & NU & .52 & $\mathrm{NU}$ & 1.36 \\
\hline 109 & 05486000 & Northwest & 349 & .01 & $<.1$ & .08 & $<.1$ & .36 \\
\hline 110 & 05486490 & Southern & 503 & 1.30 & 2.04 & 1.82 & 2.49 & 3.04 \\
\hline 111 & 05487470 & Southern & 460 & .57 & .67 & .76 & .81 & 1.20 \\
\hline 112 & 05487540 & Southern & 6.78 & .05 & $\mathrm{NU}$ & .08 & $\mathrm{NU}$ & .14 \\
\hline 113 & 05487550 & Southern & 20.3 & .07 & .00 & .11 & .00 & .28 \\
\hline
\end{tabular}


Table 2. Selected low-flow frequency statistics and harmonic mean flows computed from observed streamflow and predicted from regional regression equations for streamgages evaluated in study.-Continued

[USGS, U.S. Geological Survey; $\mathrm{mi}^{2}$, square miles; M1D10Y, annual 1-day mean low flow for a recurrence interval of 10 years; $\mathrm{ft}^{3} / \mathrm{s}$, cubic feet per second; M7D10Y, annual 7-day mean low flow for a recurrence interval of 10 years; M30D10Y, annual 30-day mean low flow for a recurrence interval of 10 years; M30D5Y, annual 30-day mean low flow for a recurrence interval of 5 years; M1D10Y1012, seasonal (October through December) 1-day mean low flow for a recurrence interval of 10 years; M7D10Y1012, seasonal (October through December) 7-day mean low flow for a recurrence interval of 10 years; QAH, harmonic mean flow. Streamgage locations are shown in figure 1; NU, streamgage not used in development of regional-regression equations; <, less than]

\begin{tabular}{|c|c|c|c|c|c|c|c|c|c|}
\hline $\begin{array}{c}\text { Map } \\
\text { number }\end{array}$ & $\begin{array}{l}\text { Predicted- } \\
\text { M30D10Y } \\
\left(\mathrm{ft}^{3} / \mathrm{s}\right)\end{array}$ & $\begin{array}{c}\text { Observed } \\
\text { M30D5Y } \\
\left(\mathrm{ft}^{3} / \mathrm{s}\right)\end{array}$ & $\begin{array}{c}\text { Predicted } \\
\text { M30D5Y } \\
\left(\mathrm{ft}^{3} / \mathrm{s}\right)\end{array}$ & $\begin{array}{c}\text { Observed } \\
\text { M1D10Y1012 } \\
\left(\mathrm{ft}^{3} / \mathrm{s}\right)\end{array}$ & $\begin{array}{c}\text { Predicted } \\
\text { M1D10Y1012 } \\
\left(\mathrm{ft}^{3} / \mathrm{s}\right)\end{array}$ & $\begin{array}{c}\text { Observed } \\
\text { M7D10Y1012 } \\
\left(\mathrm{ft}^{3} / \mathrm{s}\right)\end{array}$ & $\begin{array}{c}\text { Predicted } \\
\text { M7D10Y1012 } \\
\left(\mathrm{ft}^{3} / \mathrm{s}\right)\end{array}$ & $\begin{array}{c}\text { Observed } \\
\text { OAH } \\
\left(\mathrm{ft}^{3} / \mathrm{s}\right)\end{array}$ & $\begin{array}{c}\text { Predicted } \\
\text { OAH } \\
\left(\mathrm{ft}^{3} / \mathrm{s}\right)\end{array}$ \\
\hline 76 & 0.67 & 1.18 & 1.71 & 0.35 & 0.74 & 0.42 & 0.99 & 3.51 & 4.33 \\
\hline 77 & .37 & .66 & 1.00 & .00 & .42 & .00 & .56 & 2.36 & 2.14 \\
\hline 78 & NU & .05 & $\mathrm{NU}$ & .00 & $\mathrm{NU}$ & .00 & $\mathrm{NU}$ & 3.00 & $\mathrm{NU}$ \\
\hline 79 & $\mathrm{NU}$ & .78 & $\mathrm{NU}$ & .36 & .00 & .47 & $<.1$ & 2.43 & .74 \\
\hline 80 & 15.1 & 26.3 & 20.8 & 16.3 & 12.1 & 18.2 & 15.3 & 88.4 & 53.1 \\
\hline 81 & .51 & 2.93 & 1.35 & 2.05 & .58 & 2.61 & .77 & 10.7 & 5.03 \\
\hline 82 & 38.7 & 38.4 & 52.1 & 17.7 & 28.9 & 20.0 & 36.6 & 135 & 148 \\
\hline 83 & 9.76 & 14.3 & 13.9 & 4.92 & 7.25 & 5.45 & 9.42 & 23.5 & 37.0 \\
\hline 84 & 2.11 & 4.72 & 3.46 & 1.40 & 1.19 & 1.71 & 1.75 & 19.3 & 12.5 \\
\hline 85 & .44 & .04 & .71 & .00 & .34 & .00 & .46 & 1.00 & 2.60 \\
\hline 86 & 102 & 105 & 139 & 53.6 & 63.2 & 61.9 & 80.9 & 397 & 594 \\
\hline 87 & $\mathrm{NU}$ & 3.65 & $\mathrm{NU}$ & 1.29 & $\mathrm{NU}$ & 3.24 & $\mathrm{NU}$ & 10.2 & $\mathrm{NU}$ \\
\hline 88 & 9.13 & 6.06 & 17.4 & 3.54 & 9.27 & 4.78 & 11.8 & 18.9 & 51.1 \\
\hline 89 & 25.5 & 48.2 & 43.2 & 34.4 & 24.9 & 41.0 & 31.3 & 182 & 79.9 \\
\hline 90 & 2.37 & 2.35 & 4.78 & 1.29 & 2.58 & 1.84 & 3.26 & 13.4 & 12.0 \\
\hline 91 & 9.80 & 23.1 & 17.9 & 13.5 & 10.0 & 15.9 & 12.7 & 86.4 & 50.6 \\
\hline 92 & .77 & .93 & 1.73 & .34 & .89 & .55 & 1.14 & 2.43 & 3.64 \\
\hline 93 & 84.3 & 101 & 130 & 54.8 & 78.0 & 71.0 & 97.3 & 355 & 222 \\
\hline 94 & 4.08 & 13.7 & 8.14 & 7.23 & 4.36 & 8.53 & 5.57 & 14.6 & 18.1 \\
\hline 95 & 144 & 132 & 212 & 76.0 & 129 & 90.2 & 161 & 492 & 289 \\
\hline 96 & .91 & .81 & 2.19 & .31 & 1.03 & .57 & 1.35 & 2.49 & 6.47 \\
\hline 97 & .86 & 3.50 & 1.81 & 1.24 & 1.00 & 1.45 & 1.26 & 11.4 & 7.75 \\
\hline 98 & .20 & .00 & .49 & .00 & .25 & .00 & .32 & .96 & 2.16 \\
\hline 99 & 3.92 & 12.3 & 7.38 & 7.83 & 4.27 & 9.33 & 5.35 & 42.0 & 56.5 \\
\hline 100 & 13.5 & 35.6 & 23.7 & 18.3 & 13.8 & 21.1 & 17.3 & 127 & 141 \\
\hline 101 & $<.1$ & .00 & .12 & .00 & $<.1$ & .00 & $<.1$ & .20 & .54 \\
\hline 102 & 8.24 & 23.9 & 11.2 & 14.5 & 7.44 & 17.7 & 9.07 & 69.3 & 24.2 \\
\hline 103 & 29.2 & 56.7 & 38.9 & 40.7 & 24.0 & 46.8 & 28.7 & 164 & 82.9 \\
\hline 104 & 38.9 & 126 & 67.6 & 82.8 & 36.9 & 96.8 & 47.2 & 429 & 481 \\
\hline 105 & NU & 167 & $\mathrm{NU}$ & 109 & $\mathrm{NU}$ & 123 & NU & 488 & $\mathrm{NU}$ \\
\hline 106 & NU & 1.68 & $\mathrm{NU}$ & .19 & $\mathrm{NU}$ & .51 & NU & 3.06 & NU \\
\hline 107 & NU & 129 & NU & 84.9 & $\mathrm{NU}$ & 104 & NU & 159 & $\mathrm{NU}$ \\
\hline 108 & NU & 2.47 & NU & .48 & $\mathrm{NU}$ & .84 & NU & 5.90 & $\mathrm{NU}$ \\
\hline 109 & $<.1$ & .96 & .28 & .10 & $<.1$ & .23 & $<.1$ & 4.28 & 5.56 \\
\hline 110 & 3.62 & 4.99 & 5.54 & 2.05 & 2.48 & 2.48 & 3.33 & 20.8 & 15.9 \\
\hline 111 & 1.44 & 2.30 & 2.42 & .85 & .78 & 1.16 & 1.19 & 8.44 & 8.52 \\
\hline 112 & NU & .19 & $\mathrm{NU}$ & .02 & .00 & .04 & .00 & .51 & .33 \\
\hline 113 & $<.1$ & .38 & $<.1$ & .10 & .00 & .13 & $<.1$ & .90 & .70 \\
\hline
\end{tabular}


Table 2. Selected low-flow frequency statistics and harmonic mean flows computed from observed streamflow and predicted from regional regression equations for streamgages evaluated in study.-Continued

[USGS, U.S. Geological Survey; $\mathrm{mi}^{2}$, square miles; M1D10Y, annual 1-day mean low flow for a recurrence interval of 10 years; $\mathrm{ft}^{3} / \mathrm{s}$, cubic feet per second; M7D10Y, annual 7-day mean low flow for a recurrence interval of 10 years; M30D10Y, annual 30-day mean low flow for a recurrence interval of 10 years; M30D5Y, annual 30-day mean low flow for a recurrence interval of 5 years; M1D10Y1012, seasonal (October through December) 1-day mean low flow for a recurrence interval of 10 years; M7D10Y1012, seasonal (October through December) 7-day mean low flow for a recurrence interval of 10 years; QAH, harmonic mean flow. Streamgage locations are shown in figure 1; NU, streamgage not used in development of regional-regression equations; $<$, less than]

\begin{tabular}{|c|c|c|c|c|c|c|c|c|}
\hline $\begin{array}{c}\text { Map } \\
\text { number }\end{array}$ & $\begin{array}{c}\text { USGS } \\
\text { streamgage } \\
\text { number }\end{array}$ & $\begin{array}{l}\text { Low-flow } \\
\text { region }\end{array}$ & $\begin{array}{c}\text { Published } \\
\text { drainage area } \\
\left(\mathrm{mi}^{2}\right)\end{array}$ & $\begin{array}{c}\text { Observed } \\
\text { M1D10Y } \\
\left(\mathrm{ft}^{3} / \mathrm{s}\right)\end{array}$ & $\begin{array}{c}\text { Predicted } \\
\text { M1D10Y } \\
\left(f^{3} / \mathbf{s}\right)\end{array}$ & $\begin{array}{c}\text { Observed } \\
\text { M7D10Y } \\
\left(\mathrm{ft}^{3} / \mathrm{s}\right)\end{array}$ & $\begin{array}{c}\text { Predicted } \\
\text { M7D10Y } \\
\left(\mathrm{ft}^{3} / \mathrm{s}\right)\end{array}$ & $\begin{array}{c}\text { Observed } \\
\text { M30D10Y } \\
\left(\mathrm{ft}^{3} / \mathrm{s}\right)\end{array}$ \\
\hline 114 & 05487980 & Southern & 342 & 0.24 & 0.27 & 0.39 & 0.32 & 0.93 \\
\hline 115 & 05488000 & Southern & 380 & .31 & .33 & .48 & .39 & .68 \\
\hline 116 & 05488200 & Southern & 90.1 & .00 & .00 & .00 & .00 & .08 \\
\hline 117 & 05489000 & Southern & 374 & .19 & .34 & .28 & .40 & .63 \\
\hline 118 & 05491000 & Southern & 105 & .00 & .00 & .00 & .00 & .00 \\
\hline 119 & 05494300 & Southern & 87.7 & .04 & .00 & .06 & .00 & .29 \\
\hline 120 & 05495000 & Southern & 400 & .16 & .33 & .19 & .39 & .66 \\
\hline 121 & 05495500 & Southern & 349 & .00 & .66 & .07 & .78 & .38 \\
\hline 122 & 05496000 & Southern & 393 & .10 & .27 & .18 & .33 & .71 \\
\hline 123 & 05497000 & Southern & 452 & .29 & .34 & .58 & .41 & .89 \\
\hline 124 & 05498000 & Southern & 393 & .21 & .27 & .26 & .32 & .43 \\
\hline 125 & 05500000 & Southern & 620 & .28 & .55 & .33 & .66 & .66 \\
\hline 126 & 05501000 & Southern & 373 & .19 & .29 & .30 & .35 & .57 \\
\hline 127 & 05502020 & Southern & 40.9 & .00 & .00 & .00 & .00 & .00 \\
\hline 128 & 05502040 & Southern & 72.7 & .00 & .00 & .00 & .00 & .03 \\
\hline 129 & 05503000 & Southern & 2.64 & .00 & .00 & .00 & .00 & .00 \\
\hline 130 & 05557000 & Southern & 86.7 & .00 & .71 & .00 & .88 & .00 \\
\hline 131 & 05568800 & Southern & 62.7 & .35 & .34 & .50 & .41 & .95 \\
\hline 132 & 05570000 & Southern & $1,635.8$ & 19.0 & 23.9 & 21.1 & 29.9 & 31.9 \\
\hline 133 & 05584400 & Southern & 26.3 & .00 & .00 & .00 & .00 & .01 \\
\hline 134 & 05584500 & Southern & 655 & 1.10 & 3.59 & 1.35 & 4.35 & 2.89 \\
\hline 135 & 05585000 & Southern & 1,293 & 6.98 & 7.87 & 8.55 & 9.60 & 13.0 \\
\hline 136 & 06478518 & Northwest & 304 & 6.85 & 26.2 & 8.14 & 27.4 & 10.6 \\
\hline 137 & 06480400 & Northwest & 63.2 & .00 & $<.1$ & .00 & $<.1$ & .03 \\
\hline 138 & 06480650 & Northwest & 100 & .00 & NU & .00 & NU & .00 \\
\hline 139 & 06481500 & Northwest & 622 & .11 & .16 & .21 & .21 & .24 \\
\hline 140 & 06482610 & NU & 464 & 3.30 & NU & 4.31 & NU & 4.87 \\
\hline 141 & 06483500 & Northwest & 1,592 & 5.63 & 3.93 & 6.38 & 4.69 & 8.00 \\
\hline 142 & 06485696 & Northwest & 204 & .69 & .36 & .98 & .43 & 1.75 \\
\hline 143 & 06600000 & Northwest & 65.1 & .74 & .27 & 1.16 & .30 & 1.86 \\
\hline 144 & 06600100 & Northwest & 268 & .46 & .39 & .56 & .46 & .87 \\
\hline 145 & 06600300 & Northwest & 180 & .07 & .20 & .07 & .24 & .09 \\
\hline 146 & 06600500 & Northwest & 886 & 6.77 & 4.98 & 7.42 & 5.45 & 9.28 \\
\hline 147 & 06601000 & Southern & 174 & 2.45 & 4.80 & 3.54 & 6.26 & 4.80 \\
\hline 148 & 06602020 & Southern & 403 & 9.12 & 10.0 & 10.5 & 12.9 & 13.4 \\
\hline 149 & 06602400 & Southern & 900 & 26.1 & 25.4 & 29.5 & 33.2 & 37.1 \\
\hline 150 & 06605000 & Northwest & 426 & 1.53 & .74 & 1.96 & .89 & 2.21 \\
\hline 151 & 06605600 & Northwest & 1,334 & 5.85 & 7.12 & 6.37 & 8.18 & 8.85 \\
\hline
\end{tabular}


Table 2. Selected low-flow frequency statistics and harmonic mean flows computed from observed streamflow and predicted from regional regression equations for streamgages evaluated in study.-Continued

[USGS, U.S. Geological Survey; $\mathrm{mi}^{2}$, square miles; M1D10Y, annual 1-day mean low flow for a recurrence interval of 10 years; $\mathrm{ft}^{3} / \mathrm{s}$, cubic feet per second; M7D10Y, annual 7-day mean low flow for a recurrence interval of 10 years; M30D10Y, annual 30-day mean low flow for a recurrence interval of 10 years; M30D5Y, annual 30-day mean low flow for a recurrence interval of 5 years; M1D10Y1012, seasonal (October through December) 1-day mean low flow for a recurrence interval of 10 years; M7D10Y1012, seasonal (October through December) 7-day mean low flow for a recurrence interval of 10 years; QAH, harmonic mean flow. Streamgage locations are shown in figure 1; NU, streamgage not used in development of regional-regression equations; <, less than]

\begin{tabular}{|c|c|c|c|c|c|c|c|c|c|}
\hline $\begin{array}{c}\text { Map } \\
\text { number }\end{array}$ & $\begin{array}{c}\text { Predicted- } \\
\text { M30D10Y } \\
\left(\mathrm{ft}^{3} / \mathrm{s}\right) \\
\end{array}$ & $\begin{array}{c}\text { Observed } \\
\text { M30D5Y } \\
\left(\mathrm{ft}^{3} / \mathrm{s}\right)\end{array}$ & $\begin{array}{c}\text { Predicted } \\
\text { M30D5Y } \\
\left(\mathrm{ft}^{3} / \mathrm{s}\right) \\
\end{array}$ & $\begin{array}{c}\text { Observed } \\
\text { M1D10Y1012 } \\
\left(\mathrm{ft}^{3} / \mathrm{s}\right) \\
\end{array}$ & $\begin{array}{c}\text { Predicted } \\
\text { M1D10Y1012 } \\
\left(\mathrm{ft}^{3} / \mathrm{s}\right) \\
\end{array}$ & $\begin{array}{c}\text { Observed } \\
\text { M7D10Y1012 } \\
\left(\mathrm{ft}^{3} / \mathrm{s}\right) \\
\end{array}$ & $\begin{array}{c}\text { Predicted } \\
\text { M7D10Y1012 } \\
\left(\mathrm{ft}^{3} / \mathrm{s}\right) \\
\end{array}$ & $\begin{array}{c}\text { Observed } \\
\text { OAH } \\
\left(\mathrm{ft}^{3} / \mathrm{s}\right) \\
\end{array}$ & $\begin{array}{c}\text { Predicted } \\
\text { OAH } \\
\left(\mathrm{ft}^{3} / \mathrm{s}\right)\end{array}$ \\
\hline 114 & 0.63 & 1.56 & 1.12 & 0.39 & 0.31 & 0.61 & 0.49 & 6.07 & 4.23 \\
\hline 115 & .77 & 1.06 & 1.36 & .38 & .38 & .53 & .60 & 3.92 & 5.02 \\
\hline 116 & .10 & .17 & .19 & .03 & $<.1$ & .04 & $<.1$ & .74 & .96 \\
\hline 117 & .78 & 1.29 & 1.37 & .45 & .39 & .58 & .61 & 4.50 & 5.31 \\
\hline 118 & .12 & .00 & .23 & .00 & $<.1$ & .00 & .10 & 1.23 & 1.49 \\
\hline 119 & .10 & .38 & .19 & .13 & .00 & .20 & .00 & 1.44 & 1.25 \\
\hline 120 & .78 & 1.41 & 1.39 & .24 & .38 & .32 & .59 & 4.80 & 6.66 \\
\hline 121 & 1.28 & .88 & 2.08 & .14 & .76 & .22 & 1.20 & 3.08 & 8.26 \\
\hline 122 & .68 & 1.54 & 1.23 & .25 & .31 & .43 & .50 & 5.46 & 6.45 \\
\hline 123 & .84 & 3.67 & 1.51 & 1.26 & .39 & 1.72 & .62 & 10.8 & 7.18 \\
\hline 124 & .66 & 1.29 & 1.19 & .33 & .31 & .50 & .49 & 5.98 & 6.04 \\
\hline 125 & 1.38 & 1.71 & 2.45 & .57 & .64 & .58 & .96 & 8.20 & 13.5 \\
\hline 126 & .69 & 1.47 & 1.25 & .37 & .34 & .64 & .51 & 5.97 & 8.36 \\
\hline 127 & .00 & .01 & .11 & .00 & .00 & .00 & .00 & .79 & .76 \\
\hline 128 & .16 & .19 & .27 & .00 & .00 & .00 & .00 & 1.88 & 1.47 \\
\hline 129 & .00 & .00 & .00 & .00 & .00 & .00 & .00 & .06 & .15 \\
\hline 130 & .94 & .00 & 1.36 & .00 & .94 & .00 & 1.19 & 1.41 & 4.36 \\
\hline 131 & .45 & 1.55 & .67 & .54 & .44 & .74 & .57 & 6.11 & 2.60 \\
\hline 132 & 39.3 & 46.6 & 52.8 & 23.6 & 29.4 & 27.2 & 37.1 & 192 & 147 \\
\hline 133 & .13 & .02 & .20 & .00 & .00 & .00 & .00 & .52 & 1.22 \\
\hline 134 & 6.16 & 5.51 & 9.05 & 1.29 & 4.25 & 1.66 & 5.98 & 19.1 & 27.6 \\
\hline 135 & 14.5 & 20.1 & 21.1 & 9.46 & 9.21 & 10.6 & 12.9 & 75.0 & 70.8 \\
\hline 136 & 15.2 & 14.5 & 16.9 & 11.6 & 15.8 & 13.8 & 17.2 & 37.3 & 33.7 \\
\hline 137 & $<.1$ & .13 & .14 & .00 & $<.1$ & .03 & $<.1$ & 1.04 & .52 \\
\hline 138 & $\mathrm{NU}$ & .02 & $\mathrm{NU}$ & .15 & .10 & .20 & .14 & .69 & .78 \\
\hline 139 & 1.06 & .87 & 2.83 & .43 & 1.07 & .62 & 1.47 & 3.02 & 13.7 \\
\hline 140 & NU & 8.56 & $\mathrm{NU}$ & 5.84 & $\mathrm{NU}$ & 7.17 & NU & 21.6 & $\mathrm{NU}$ \\
\hline 141 & 9.18 & 15.0 & 18.3 & 7.28 & 9.15 & 10.3 & 11.9 & 22.8 & 41.7 \\
\hline 142 & .67 & 2.88 & 1.46 & .90 & .80 & 1.27 & 1.01 & 9.48 & 8.22 \\
\hline 143 & .30 & 3.19 & .58 & 1.12 & .37 & 1.71 & .46 & 5.52 & 4.15 \\
\hline 144 & .76 & 1.92 & 1.70 & 1.39 & .90 & 1.76 & 1.15 & 8.41 & 4.84 \\
\hline 145 & .44 & .58 & 1.04 & .55 & .53 & .69 & .69 & 3.00 & 6.72 \\
\hline 146 & 5.64 & 19.5 & 10.0 & 11.7 & 6.08 & 15.0 & 7.57 & 61.8 & 61.6 \\
\hline 147 & 8.17 & 8.80 & 10.6 & 3.15 & 7.05 & 4.40 & 9.59 & 18.7 & 16.1 \\
\hline 148 & 15.2 & 21.3 & 19.8 & 11.2 & 13.8 & 13.5 & 16.8 & 57.2 & 34.0 \\
\hline 149 & 46.7 & 52.8 & 60.7 & 29.8 & 35.6 & 36.7 & 43.5 & 129 & 120 \\
\hline 150 & 1.58 & 5.54 & 3.38 & 3.18 & 1.77 & 4.10 & 2.26 & 15.2 & 12.4 \\
\hline 151 & 11.2 & 12.9 & 20.0 & 11.3 & 11.4 & 12.8 & 14.3 & 60.1 & 72.6 \\
\hline
\end{tabular}


Table 2. Selected low-flow frequency statistics and harmonic mean flows computed from observed streamflow and predicted from regional regression equations for streamgages evaluated in study.-Continued

[USGS, U.S. Geological Survey; $\mathrm{mi}^{2}$, square miles; M1D10Y, annual 1-day mean low flow for a recurrence interval of 10 years; $\mathrm{ft}^{3} / \mathrm{s}$, cubic feet per second; M7D10Y, annual 7-day mean low flow for a recurrence interval of 10 years; M30D10Y, annual 30-day mean low flow for a recurrence interval of 10 years; M30D5Y, annual 30-day mean low flow for a recurrence interval of 5 years; M1D10Y1012, seasonal (October through December) 1-day mean low flow for a recurrence interval of 10 years; M7D10Y1012, seasonal (October through December) 7-day mean low flow for a recurrence interval of 10 years; QAH, harmonic mean flow. Streamgage locations are shown in figure 1; NU, streamgage not used in development of regional-regression equations; $<$, less than]

\begin{tabular}{|c|c|c|c|c|c|c|c|c|}
\hline$\underset{\text { Mumber }}{\text { Map }}$ & $\begin{array}{c}\text { USGS } \\
\text { streamgage } \\
\text { number }\end{array}$ & $\begin{array}{l}\text { Low-flow } \\
\text { region }\end{array}$ & $\begin{array}{c}\text { Published } \\
\text { drainage area } \\
\left(\mathrm{mi}^{2}\right)\end{array}$ & $\begin{array}{c}\text { Observed } \\
\text { M1D10Y } \\
\left(\mathrm{ft}^{3} / \mathbf{s}\right)\end{array}$ & $\begin{array}{c}\text { Predicted } \\
\text { M1D10Y } \\
\left(\mathrm{ft}^{3} / \mathrm{s}\right)\end{array}$ & $\begin{array}{c}\text { Observed } \\
\text { M7D10Y } \\
\text { (fts } / \mathrm{s})\end{array}$ & $\begin{array}{c}\text { Predicted } \\
\text { M7D10Y } \\
\left(\mathrm{ft}^{3} / \mathrm{s}\right)\end{array}$ & $\begin{array}{c}\text { Observec } \\
\text { M30D10Y } \\
\left(\mathrm{ft}^{3} / \mathbf{s}\right)\end{array}$ \\
\hline 152 & 06605850 & Northwest & 1,548 & 7.17 & 9.77 & 8.55 & 11.0 & 11.5 \\
\hline 153 & 06606600 & Northwest & 2,500 & 25.4 & 35.2 & 28.5 & 37.9 & 33.8 \\
\hline 154 & 06607000 & Southern & 39.3 & .41 & .22 & .49 & .27 & .64 \\
\hline 155 & 06607200 & Southern & 669 & 12.4 & 15.4 & 13.8 & 19.7 & 16.6 \\
\hline 156 & 06607500 & Southern & 3,526 & 53.3 & 106 & 59.0 & 135 & 71.3 \\
\hline 157 & 06608000 & NU & 23.0 & .01 & NU & .02 & $\mathrm{NU}$ & .08 \\
\hline 158 & 06608500 & Southern & 407 & 9.58 & 11.5 & 11.1 & 14.9 & 14.1 \\
\hline 159 & 06609500 & Southern & 871 & 13.6 & 24.6 & 15.6 & 31.6 & 20.3 \\
\hline 160 & 06610500 & Southern & 7.99 & .00 & .00 & .00 & .00 & .00 \\
\hline 161 & 06610520 & Southern & 32 & .00 & .36 & .02 & .46 & .09 \\
\hline 162 & 06799385 & NU & 204 & 1.26 & $\mathrm{NU}$ & 1.91 & $\mathrm{NU}$ & 3.79 \\
\hline 163 & 06799450 & $\mathrm{NU}$ & 731 & 14.8 & $\mathrm{NU}$ & 17.2 & $\mathrm{NU}$ & 23.4 \\
\hline 164 & 06799500 & NU & 1,015 & 30.9 & $\mathrm{NU}$ & 35.6 & $\mathrm{NU}$ & 44.4 \\
\hline 165 & 06803510 & Southern & 43.6 & .40 & .00 & .53 & .00 & 1.03 \\
\hline 166 & 06803530 & Southern & 120 & 1.49 & 2.74 & 2.26 & 3.58 & 3.39 \\
\hline 167 & 06804000 & Southern & 273 & 8.15 & 8.75 & 9.54 & 11.5 & 11.9 \\
\hline 168 & 06806000 & Southern & 30.4 & .35 & .00 & .61 & .00 & 1.32 \\
\hline 169 & 06806500 & $\mathrm{NU}$ & 241 & 1.47 & $\mathrm{NU}$ & 1.87 & $\mathrm{NU}$ & 2.74 \\
\hline 170 & 06807410 & Southern & 609 & 11.1 & 12.7 & 12.6 & 16.2 & 16.2 \\
\hline 171 & 06808500 & Southern & 1,326 & 50.4 & 42.9 & 55.8 & 55.7 & 71.0 \\
\hline 172 & 06809000 & Southern & 26 & .00 & .00 & .00 & .16 & .04 \\
\hline 173 & 06809210 & Southern & 436 & 7.95 & 6.08 & 11.1 & 7.71 & 13.6 \\
\hline 174 & 06809500 & Southern & 894 & 23.1 & 15.8 & 26.8 & 20.1 & 34.1 \\
\hline 175 & 06810000 & Southern & 2,806 & 78.8 & 102 & 88.7 & 133 & 113 \\
\hline 176 & 06810500 & NU & 218 & .09 & $\mathrm{NU}$ & .38 & $\mathrm{NU}$ & .88 \\
\hline 177 & 06811500 & Southern & 792 & 7.82 & 10.8 & 9.89 & 14.3 & 16.3 \\
\hline 178 & 06811840 & Southern & 49.3 & .00 & .00 & .00 & .00 & .04 \\
\hline 179 & 06813000 & Southern & 508 & .08 & 5.95 & .41 & 7.56 & 3.17 \\
\hline 180 & 06814500 & Southern & 548 & 3.35 & 6.02 & 4.88 & 7.93 & 8.79 \\
\hline 181 & 06815000 & $\mathrm{NU}$ & 1,339 & 9.28 & NU & 13.5 & $\mathrm{NU}$ & 25.0 \\
\hline 182 & 06815500 & Southern & 188 & 2.27 & 1.28 & 3.50 & 1.66 & 6.09 \\
\hline 183 & 06816000 & Southern & 4.90 & .00 & .00 & .00 & .00 & .00 \\
\hline 184 & 06817000 & Southern & 762 & 9.96 & 7.04 & 12.3 & 8.85 & 16.3 \\
\hline 185 & 06817500 & Southern & 1,240 & 7.65 & 13.4 & 11.4 & 16.9 & 17.8 \\
\hline 186 & 06817700 & Southern & 1,380 & 24.0 & 16.9 & 28.6 & 21.5 & 35.8 \\
\hline 187 & 06818750 & Southern & 217 & .34 & .67 & .55 & .82 & 1.01 \\
\hline 188 & 06818900 & Southern & 486 & 2.72 & 1.57 & 3.18 & 1.91 & 4.99 \\
\hline 189 & 06819185 & Southern & 85.4 & .00 & .00 & .00 & .00 & .15 \\
\hline
\end{tabular}


Table 2. Selected low-flow frequency statistics and harmonic mean flows computed from observed streamflow and predicted from regional regression equations for streamgages evaluated in study.-Continued

[USGS, U.S. Geological Survey; $\mathrm{mi}^{2}$, square miles; M1D10Y, annual 1-day mean low flow for a recurrence interval of 10 years; $\mathrm{ft}^{3} / \mathrm{s}$, cubic feet per second; M7D10Y, annual 7-day mean low flow for a recurrence interval of 10 years; M30D10Y, annual 30-day mean low flow for a recurrence interval of 10 years; M30D5Y, annual 30-day mean low flow for a recurrence interval of 5 years; M1D10Y1012, seasonal (October through December) 1-day mean low flow for a recurrence interval of 10 years; M7D10Y1012, seasonal (October through December) 7-day mean low flow for a recurrence interval of 10 years; QAH, harmonic mean flow. Streamgage locations are shown in figure 1; NU, streamgage not used in development of regional-regression equations; <, less than]

\begin{tabular}{|c|c|c|c|c|c|c|c|c|c|}
\hline $\begin{array}{c}\text { Map } \\
\text { number }\end{array}$ & $\begin{array}{l}\text { Predicted- } \\
\text { M30D10Y } \\
\left(\mathrm{ft}^{3} / \mathrm{s}\right)\end{array}$ & $\begin{array}{c}\text { Observed } \\
\text { M30D5Y } \\
\left(\mathrm{ft}^{3} / \mathrm{s}\right)\end{array}$ & $\begin{array}{c}\text { Predicted } \\
\text { M30D5Y } \\
\left(\mathrm{ft}^{3} / \mathrm{s}\right)\end{array}$ & $\begin{array}{c}\text { Observed } \\
\text { M1D10Y1012 } \\
\left(\mathrm{ft}^{3} / \mathrm{s}\right)\end{array}$ & $\begin{array}{c}\text { Predicted } \\
\text { M1D10Y1012 } \\
\left(\mathrm{ft}^{3} / \mathrm{s}\right)\end{array}$ & $\begin{array}{c}\text { Observed } \\
\text { M7D10Y1012 } \\
\left(\mathrm{ft}^{3} / \mathrm{s}\right)\end{array}$ & $\begin{array}{c}\text { Predicted } \\
\text { M7D10Y1012 } \\
\left(\mathrm{ft}^{3} / \mathrm{s}\right)\end{array}$ & $\begin{array}{c}\text { Observed } \\
\text { OAH } \\
\left(\mathrm{ft}^{3} / \mathrm{s}\right)\end{array}$ & $\begin{array}{c}\text { Predicted } \\
\text { OAH } \\
\left(\mathrm{ft}^{3} / \mathrm{s}\right)\end{array}$ \\
\hline 152 & 14.4 & 23.4 & 25.2 & 14.0 & 14.5 & 17.3 & 18.2 & 87.1 & 89.6 \\
\hline 153 & 37.6 & 55.9 & 58.9 & 33.7 & 36.7 & 41.4 & 45.3 & 213 & 167 \\
\hline 154 & .28 & .88 & .42 & .71 & .29 & .86 & .38 & 3.56 & 1.87 \\
\hline 155 & 23.5 & 29.4 & 30.8 & 18.8 & 20.7 & 24.2 & 24.6 & 96.0 & 57.7 \\
\hline 156 & 178 & 117 & 225 & 74.5 & 134 & 89.6 & 158 & 410 & 693 \\
\hline 157 & $\mathrm{NU}$ & .17 & $\mathrm{NU}$ & .09 & $\mathrm{NU}$ & .12 & $\mathrm{NU}$ & .44 & $\mathrm{NU}$ \\
\hline 158 & 17.9 & 23.1 & 23.2 & 13.6 & 16.1 & 16.1 & 19.8 & 57.2 & 37.1 \\
\hline 159 & 38.5 & 36.4 & 49.5 & 23.3 & 33.2 & 27.5 & 39.4 & 106 & 89.4 \\
\hline 160 & $<.1$ & .05 & $<.1$ & .00 & .00 & .00 & .00 & .30 & .71 \\
\hline 161 & .49 & .18 & .69 & .06 & .52 & .10 & .68 & .88 & 2.44 \\
\hline 162 & $\mathrm{NU}$ & 5.39 & $\mathrm{NU}$ & 2.70 & $\mathrm{NU}$ & 3.84 & NU & 13.9 & NU \\
\hline 163 & $\mathrm{NU}$ & 31.0 & $\mathrm{NU}$ & 21.1 & $\mathrm{NU}$ & 27.2 & $\mathrm{NU}$ & 80.7 & $\mathrm{NU}$ \\
\hline 164 & $\mathrm{NU}$ & 64.8 & $\mathrm{NU}$ & 41.9 & $\mathrm{NU}$ & 49.4 & $\mathrm{NU}$ & 144 & $\mathrm{NU}$ \\
\hline 165 & .95 & 1.41 & 1.35 & .50 & .77 & .75 & 1.14 & 4.01 & 3.98 \\
\hline 166 & 5.10 & 4.13 & 6.76 & 3.22 & 4.10 & 3.94 & 5.93 & 10.4 & 11.2 \\
\hline 167 & 17.0 & 15.2 & 21.8 & 9.20 & 13.0 & 10.9 & 18.5 & 31.3 & 28.9 \\
\hline 168 & .42 & 1.60 & .60 & 1.17 & .45 & 1.51 & .58 & 3.96 & 2.27 \\
\hline 169 & NU & 5.62 & $\mathrm{NU}$ & 2.58 & $\mathrm{NU}$ & 3.21 & NU & 14.6 & NU \\
\hline 170 & 19.6 & 28.5 & 26.0 & 17.5 & 17.0 & 20.4 & 20.3 & 85.5 & 48.1 \\
\hline 171 & 71.0 & 97.4 & 90.1 & 62.3 & 58.1 & 72.7 & 68.5 & 265 & 164 \\
\hline 172 & .16 & .11 & .25 & .00 & .17 & .00 & .22 & .83 & 1.32 \\
\hline 173 & 9.58 & 20.1 & 13.2 & 11.8 & 8.12 & 14.1 & 9.77 & 59.8 & 26.4 \\
\hline 174 & 26.0 & 47.7 & 35.0 & 31.2 & 20.9 & 37.7 & 24.8 & 140 & 69.8 \\
\hline 175 & 178 & 167 & 223 & 88.6 & 136 & 108 & 158 & 490 & 512 \\
\hline 176 & NU & 1.93 & NU & .34 & $\mathrm{NU}$ & .56 & $\mathrm{NU}$ & 4.91 & $\mathrm{NU}$ \\
\hline 177 & 26.1 & 23.3 & 36.8 & 18.0 & 15.5 & 21.2 & 20.3 & 66.3 & 106 \\
\hline 178 & .35 & .13 & .54 & .00 & .34 & .04 & .43 & .59 & 2.29 \\
\hline 179 & 9.71 & 6.48 & 13.6 & 1.99 & 7.94 & 3.31 & 9.54 & 18.8 & 27.1 \\
\hline 180 & 14.7 & 13.4 & 21.2 & 7.63 & 8.73 & 9.59 & 11.5 & 25.0 & 64.4 \\
\hline 181 & $\mathrm{NU}$ & 33.5 & $\mathrm{NU}$ & 16.2 & $\mathrm{NU}$ & 22.0 & $\mathrm{NU}$ & 96.0 & $\mathrm{NU}$ \\
\hline 182 & 2.66 & 7.94 & 4.03 & 3.48 & 1.84 & 4.79 & 2.36 & 18.8 & 14.7 \\
\hline 183 & .00 & .05 & $<.1$ & .00 & .00 & .00 & .00 & .46 & .52 \\
\hline 184 & 12.1 & 21.3 & 17.3 & 11.9 & 9.02 & 14.8 & 11.0 & 70.3 & 40.2 \\
\hline 185 & 24.2 & 24.8 & 34.2 & 10.3 & 17.0 & 15.0 & 20.6 & 89.1 & 84.2 \\
\hline 186 & 31.1 & 45.6 & 43.7 & 32.7 & 21.6 & 36.0 & 25.9 & 159 & 107 \\
\hline 187 & 1.13 & 1.58 & 1.78 & .78 & .83 & 1.32 & 1.13 & 7.49 & 6.22 \\
\hline 188 & 2.93 & 6.36 & 4.60 & 3.04 & 1.90 & 3.66 & 2.57 & 22.1 & 14.2 \\
\hline 189 & .21 & .26 & .36 & .00 & .15 & .04 & .22 & .91 & 1.65 \\
\hline
\end{tabular}




\section{Methods for Estimating Selected Low-Flow Frequency Statistics and Harmonic Mean Flows for Streams in lowa}

Table 2. Selected low-flow frequency statistics and harmonic mean flows computed from observed streamflow and predicted from regional regression equations for streamgages evaluated in study.-Continued

[USGS, U.S. Geological Survey; $\mathrm{mi}^{2}$, square miles; M1D10Y, annual 1-day mean low flow for a recurrence interval of 10 years; $\mathrm{ft}^{3} / \mathrm{s}$, cubic feet per second; M7D10Y, annual 7-day mean low flow for a recurrence interval of 10 years; M30D10Y, annual 30-day mean low flow for a recurrence interval of 10 years; M30D5Y, annual 30-day mean low flow for a recurrence interval of 5 years; M1D10Y1012, seasonal (October through December) 1-day mean low flow for a recurrence interval of 10 years; M7D10Y1012, seasonal (October through December) 7-day mean low flow for a recurrence interval of 10 years; QAH, harmonic mean flow. Streamgage locations are shown in figure 1; NU, streamgage not used in development of regional-regression equations; <, less than]

\begin{tabular}{|c|c|c|c|c|c|c|c|c|}
\hline $\begin{array}{c}\text { Map } \\
\text { number }\end{array}$ & $\begin{array}{c}\text { USGS } \\
\text { streamgage } \\
\text { number }\end{array}$ & $\begin{array}{l}\text { Low-flow } \\
\text { region }\end{array}$ & $\begin{array}{c}\text { Published } \\
\text { drainage area } \\
\left(\mathrm{mi}^{2}\right)\end{array}$ & $\begin{array}{l}\text { Observed } \\
\text { M1D10Y } \\
\left(\mathrm{ft}^{3} / \mathrm{s}\right)\end{array}$ & $\begin{array}{c}\text { Predicted } \\
\text { M1D10Y } \\
\left(\mathrm{ft}^{3} / \mathrm{s}\right)\end{array}$ & $\begin{array}{c}\text { Observed } \\
\text { M7D10Y } \\
\text { (ft/s/s) }\end{array}$ & $\begin{array}{l}\text { Predicted } \\
\text { M7D10Y } \\
\left(\mathrm{ft}^{3} / \mathrm{s}\right)\end{array}$ & $\begin{array}{c}\text { Observed } \\
\text { M30D10Y } \\
\left(\mathrm{ftt}^{3} / \mathbf{s}\right)\end{array}$ \\
\hline 190 & 06819190 & Southern & 92.1 & 0.00 & 0.00 & 0.00 & 0.00 & 0.04 \\
\hline 191 & 06819500 & Southern & 500 & .00 & 1.93 & .18 & 2.37 & .24 \\
\hline 192 & 06820000 & Southern & 6.00 & .00 & .00 & .00 & .00 & .00 \\
\hline 193 & 06896500 & Southern & 5.58 & .00 & .00 & .00 & .00 & .00 \\
\hline 194 & 06897000 & Southern & 95.0 & .00 & .00 & .00 & .00 & .00 \\
\hline 195 & 06897500 & Southern & 2,250 & 5.76 & 7.47 & 7.02 & 9.32 & 10.2 \\
\hline 196 & 06897950 & Southern & 52.5 & .00 & .00 & .00 & .00 & .00 \\
\hline 197 & 06898000 & Southern & 701 & 1.15 & 1.40 & 1.65 & 1.69 & 2.86 \\
\hline 198 & 06898100 & Southern & 891 & 9.10 & 1.78 & 9.27 & 2.16 & 12.2 \\
\hline 199 & 06898400 & Southern & 104 & .00 & .00 & .00 & .00 & .08 \\
\hline 200 & 06898500 & Southern & 246 & .00 & .20 & .00 & .23 & .00 \\
\hline 201 & 06899000 & Southern & 494 & .00 & .51 & .05 & .60 & .25 \\
\hline 202 & 06900000 & Southern & 225 & .07 & .17 & .26 & .20 & 1.12 \\
\hline 203 & 06901500 & Southern & 550 & 1.04 & .66 & 1.16 & .80 & 1.68 \\
\hline 204 & 06902500 & Southern & 2.51 & .00 & .00 & .00 & .00 & .00 \\
\hline 205 & 06903400 & Southern & 182 & .00 & .00 & .00 & .12 & .03 \\
\hline 206 & 06903500 & Southern & 13.2 & .00 & $\mathrm{NU}$ & .00 & $\mathrm{NU}$ & .00 \\
\hline 207 & 06903700 & Southern & 168 & .04 & .00 & .06 & .00 & .26 \\
\hline 208 & 06904500 & Southern & 1,370 & 1.58 & 1.93 & 1.99 & 2.32 & 2.82 \\
\hline
\end{tabular}


Table 2. Selected low-flow frequency statistics and harmonic mean flows computed from observed streamflow and predicted from regional regression equations for streamgages evaluated in study.-Continued

[USGS, U.S. Geological Survey; $\mathrm{mi}^{2}$, square miles; M1D10Y, annual 1-day mean low flow for a recurrence interval of 10 years; $\mathrm{ft}^{3} / \mathrm{s}$, cubic feet per second; M7D10Y, annual 7-day mean low flow for a recurrence interval of 10 years; M30D10Y, annual 30-day mean low flow for a recurrence interval of 10 years; M30D5Y, annual 30-day mean low flow for a recurrence interval of 5 years; M1D10Y1012, seasonal (October through December) 1-day mean low flow for a recurrence interval of 10 years; M7D10Y1012, seasonal (October through December) 7-day mean low flow for a recurrence interval of 10 years; QAH, harmonic mean flow. Streamgage locations are shown in figure 1; NU, streamgage not used in development of regional-regression equations; <, less than]

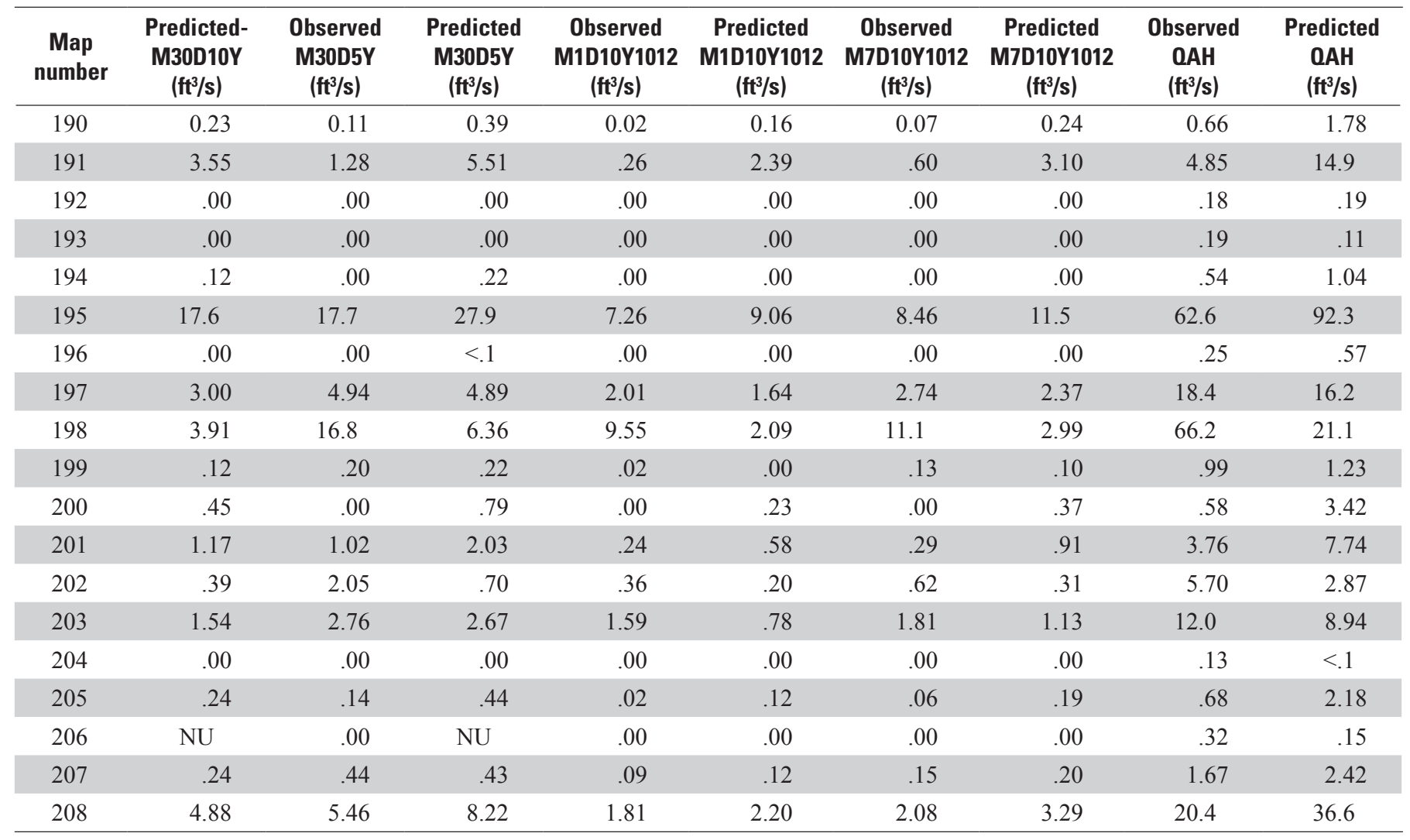


Table 3. Hydrologic characteristics computed from observed streamflow and basin characteristics measured for streamgages evaluated in study.

[USGS, U.S. Geological Survey; $\mathrm{mi}^{2}$, square miles; BFI, base-flow index; HYSEP, hydrograph separation and analysis of base flow; TAU_ANN, annual base-flow-recession time constant; STREAM_VAR, streamflow-variability index; GIS, geographic information system; SOILASSURGO, hydrologic soil type A; SOILBSSURGO, hydrologic soil type B; SOILCSSURGO, hydrologic soil type C; KSATSSUR, average soil permeability; $\mu \mathrm{m} / \mathrm{s}$, micrometer per second; DRNFREQ, drainage frequency; RSD, relative stream density; NU, streamgage not used in development of regional-regression equations. Streamgage locations are shown in figure 1]

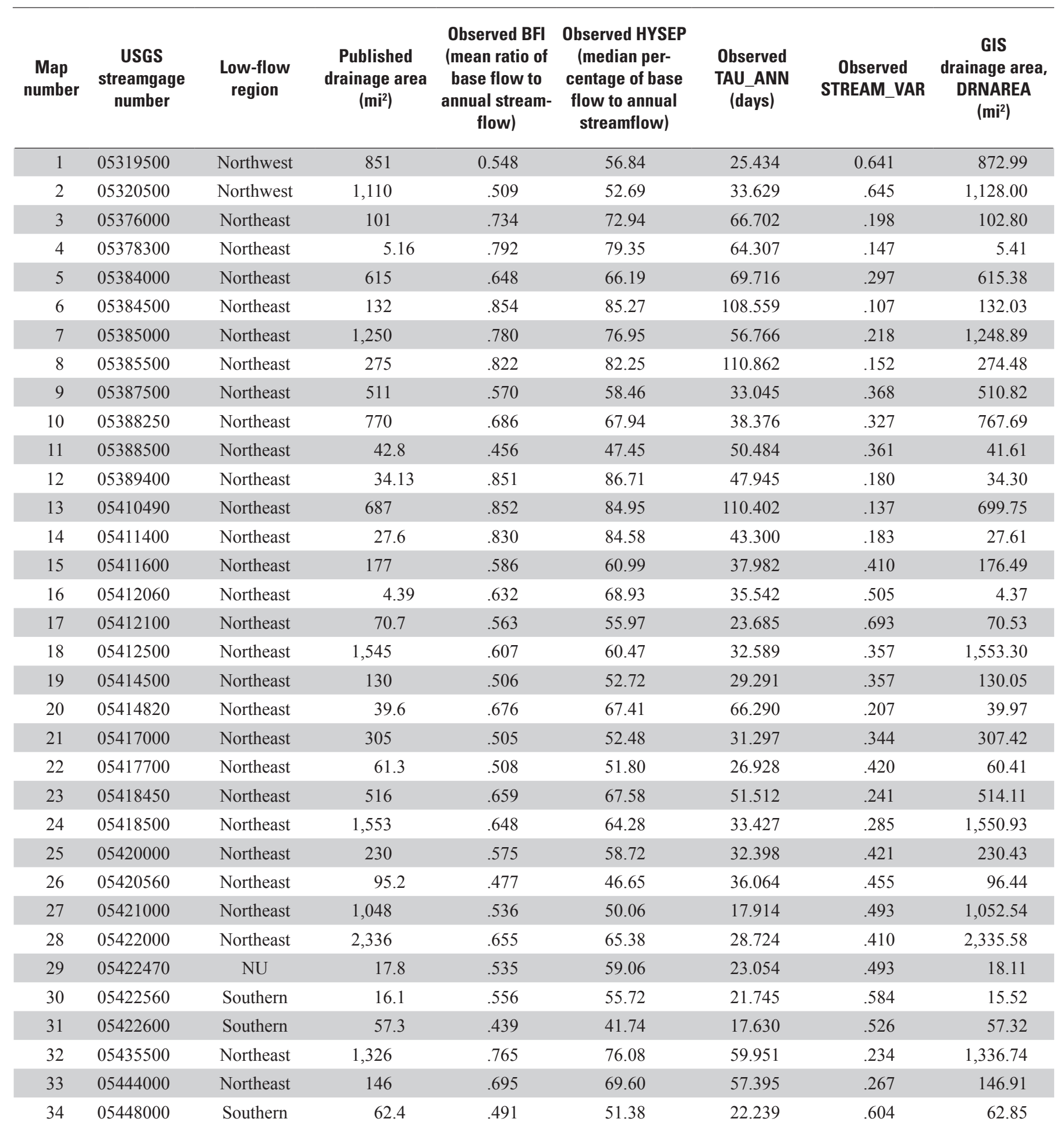


Table 3. Hydrologic characteristics computed from observed streamflow and basin characteristics measured for streamgages evaluated in study.-Continued

[USGS, U.S. Geological Survey; mi $^{2}$, square miles; BFI, base-flow index; HYSEP, hydrograph separation and analysis of base flow; TAU_ANN, annual base-flow-recession time constant; STREAM_VAR, streamflow-variability index; GIS, geographic information system; SOILASSURGO, hydrologic soil type A; SOILBSSURGO, hydrologic soil type B; SOILCSSURGO, hydrologic soil type C; KSATSSUR, average soil permeability; $\mu \mathrm{m} / \mathrm{s}$, micrometer per second; DRNFREQ, drainage frequency; RSD, relative stream density; NU, streamgage not used in development of regional-regression equations. Streamgage locations are shown in figure 1]

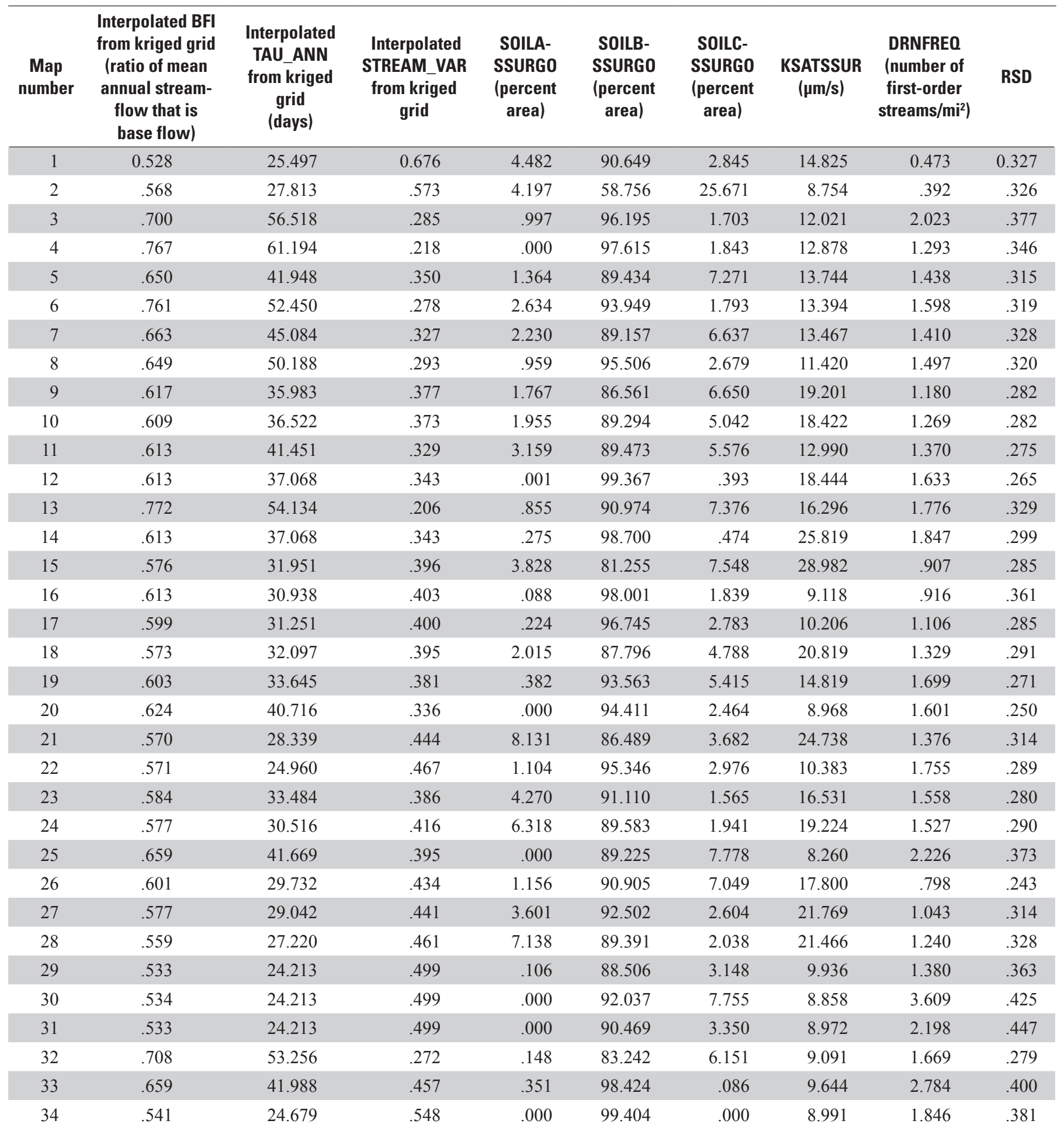


Table 3. Hydrologic characteristics computed from observed streamflow and basin characteristics measured for streamgages evaluated in study.-Continued

[USGS, U.S. Geological Survey; $\mathrm{mi}^{2}$, square miles; BFI, base-flow index; HYSEP, hydrograph separation and analysis of base flow; TAU_ANN, annual base-flow-recession time constant; STREAM_VAR, streamflow-variability index; GIS, geographic information system; SOILASSURGO, hydrologic soil type A; SOILBSSURGO, hydrologic soil type B; SOILCSSURGO, hydrologic soil type C; KSATSSUR, average soil permeability; $\mu \mathrm{m} / \mathrm{s}$, micrometer per second; DRNFREQ, drainage frequency; RSD, relative stream density; NU, streamgage not used in development of regional-regression equations. Streamgage locations are shown in figure 1]

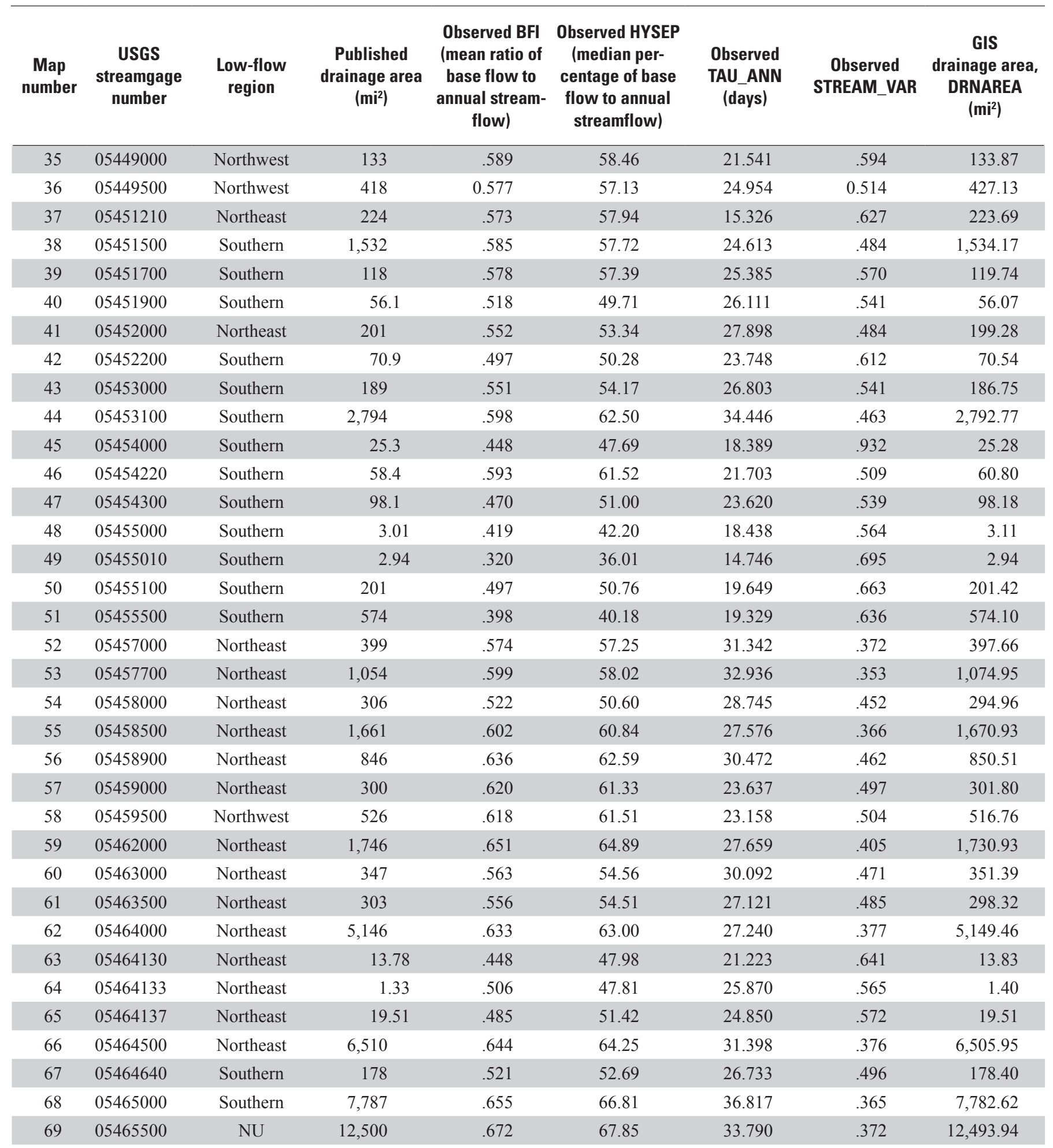


Table 3. Hydrologic characteristics computed from observed streamflow and basin characteristics measured for streamgages evaluated in study.-Continued

[USGS, U.S. Geological Survey; mi $^{2}$, square miles; BFI, base-flow index; HYSEP, hydrograph separation and analysis of base flow; TAU_ANN, annual base-flow-recession time constant; STREAM_VAR, streamflow-variability index; GIS, geographic information system; SOILASSURGO, hydrologic soil type A; SOILBSSURGO, hydrologic soil type B; SOILCSSURGO, hydrologic soil type C; KSATSSUR, average soil permeability; $\mu \mathrm{m} / \mathrm{s}$, micrometer per second; DRNFREQ, drainage frequency; RSD, relative stream density; NU, streamgage not used in development of regional-regression equations. Streamgage locations are shown in figure 1]

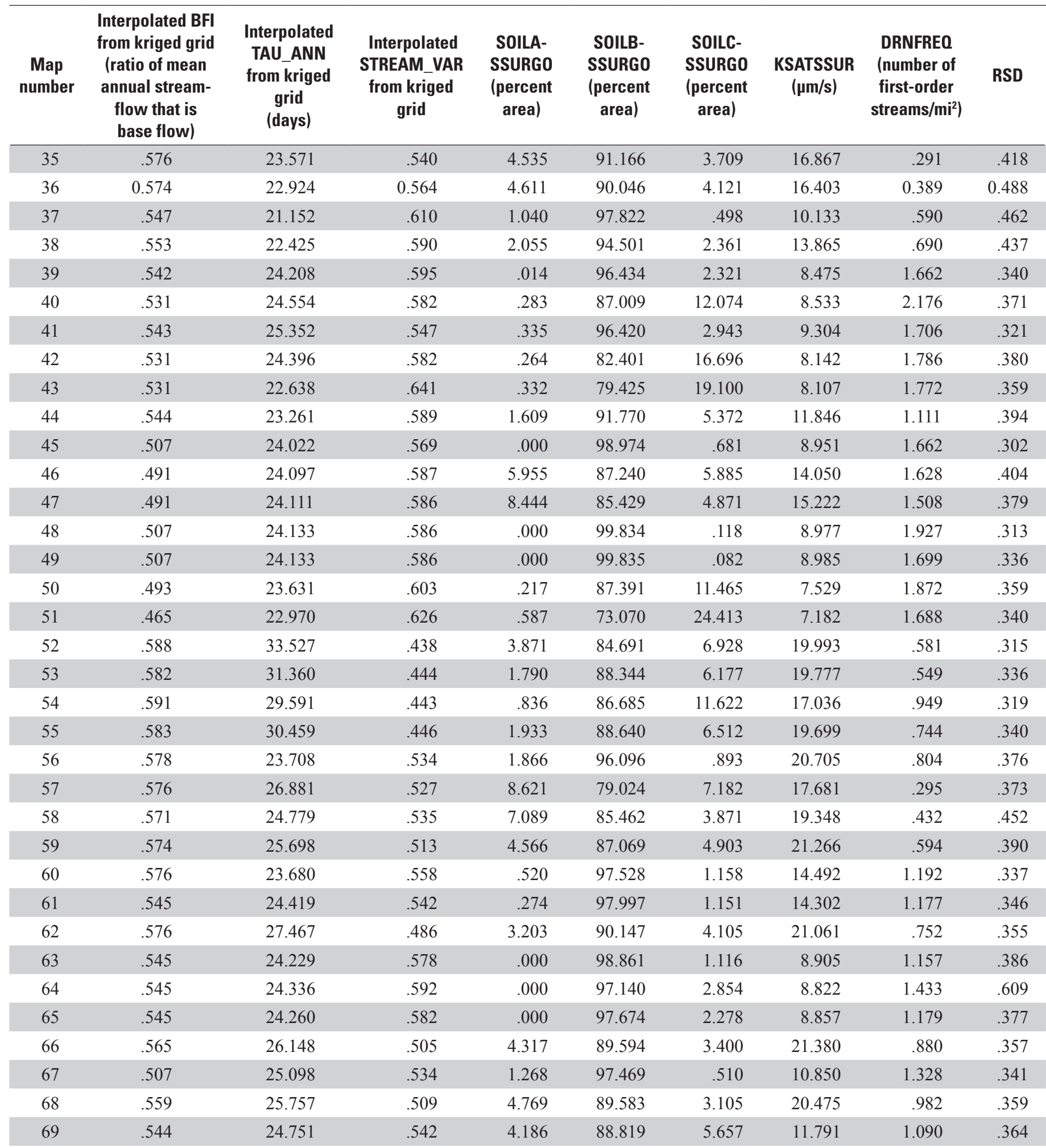


Table 3. Hydrologic characteristics computed from observed streamflow and basin characteristics measured for streamgages evaluated in study.-Continued

[USGS, U.S. Geological Survey; $\mathrm{mi}^{2}$, square miles; BFI, base-flow index; HYSEP, hydrograph separation and analysis of base flow; TAU_ANN, annual base-flow-recession time constant; STREAM_VAR, streamflow-variability index; GIS, geographic information system; SOILASSURGO, hydrologic soil type A; SOILBSSURGO, hydrologic soil type B; SOILCSSURGO, hydrologic soil type C; KSATSSUR, average soil permeability; $\mu \mathrm{m} / \mathrm{s}$, micrometer per second; DRNFREQ, drainage frequency; RSD, relative stream density; NU, streamgage not used in development of regional-regression equations. Streamgage locations are shown in figure 1]

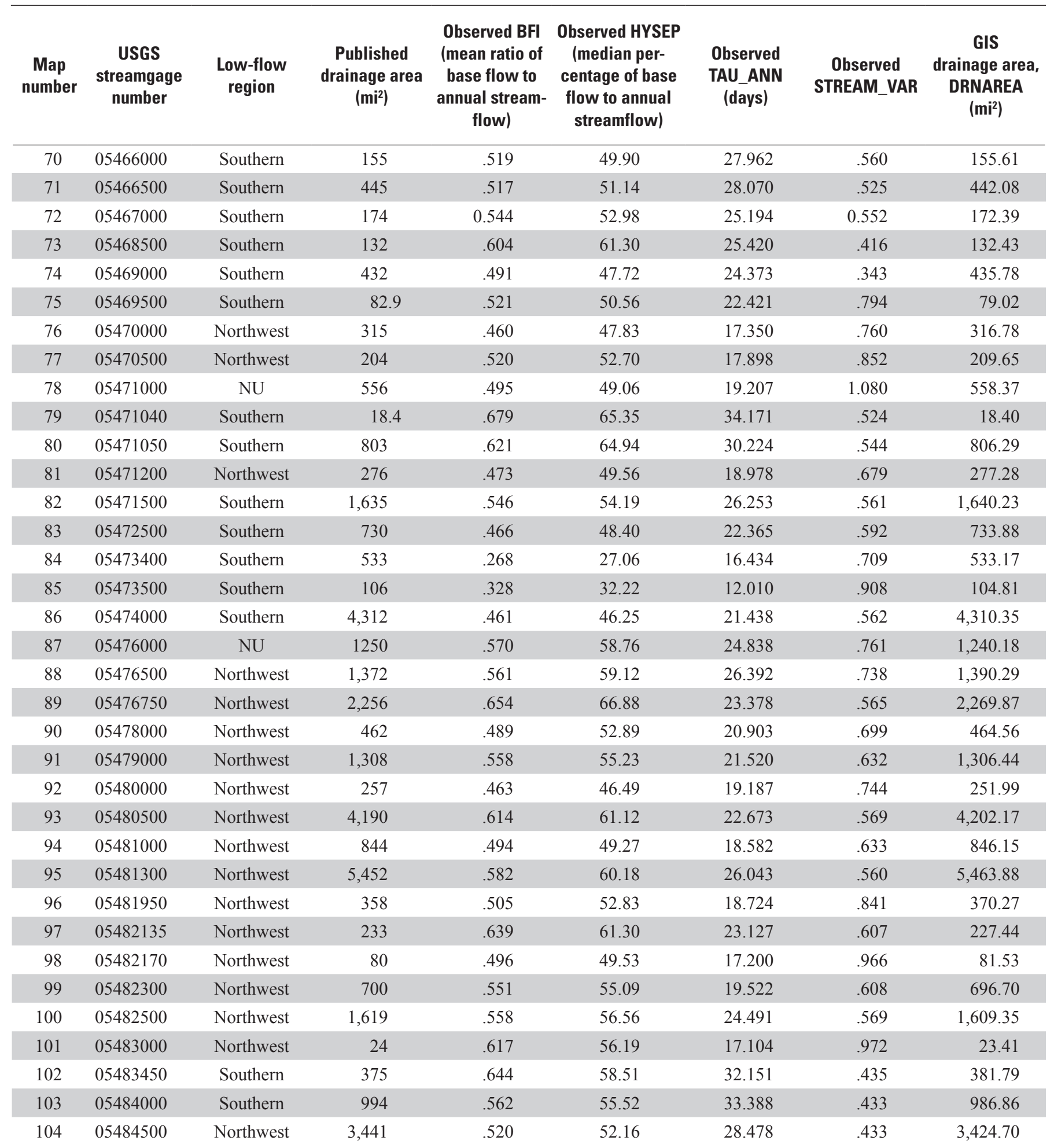


Table 3. Hydrologic characteristics computed from observed streamflow and basin characteristics measured for streamgages evaluated in study.-Continued

[USGS, U.S. Geological Survey; mi² $^{2}$ square miles; BFI, base-flow index; HYSEP, hydrograph separation and analysis of base flow; TAU_ANN, annual base-flow-recession time constant; STREAM_VAR, streamflow-variability index; GIS, geographic information system; SOILASSURGO, hydrologic soil type A; SOILBSSURGO, hydrologic soil type B; SOILCSSURGO, hydrologic soil type C; KSATSSUR, average soil permeability; $\mu \mathrm{m} / \mathrm{s}$, micrometer per second; DRNFREQ, drainage frequency; RSD, relative stream density; NU, streamgage not used in development of regional-regression equations. Streamgage locations are shown in figure 1]

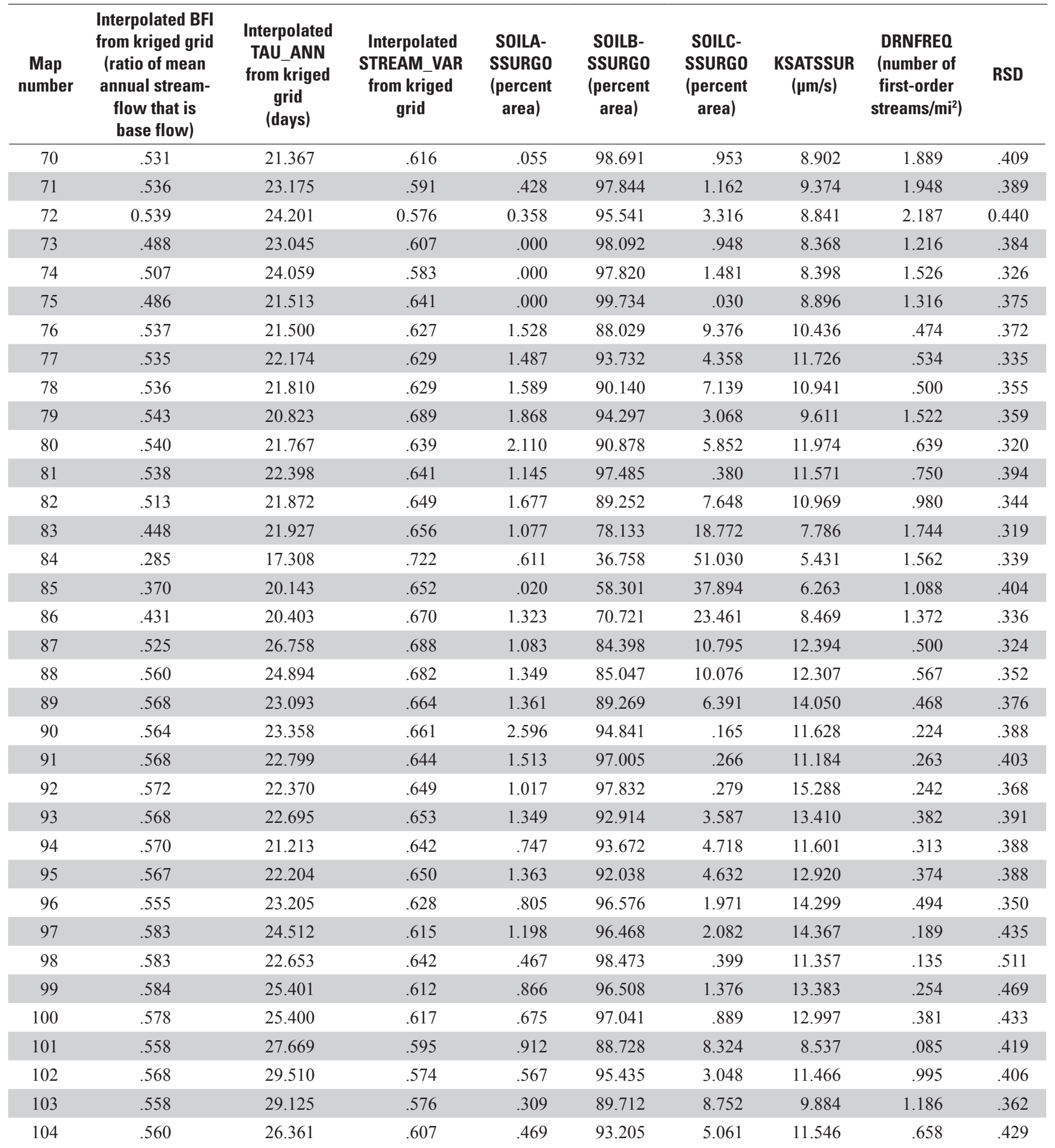


Table 3. Hydrologic characteristics computed from observed streamflow and basin characteristics measured for streamgages evaluated in study.-Continued

[USGS, U.S. Geological Survey; $\mathrm{mi}^{2}$, square miles; BFI, base-flow index; HYSEP, hydrograph separation and analysis of base flow; TAU_ANN, annual base-flow-recession time constant; STREAM_VAR, streamflow-variability index; GIS, geographic information system; SOILASSURGO, hydrologic soil type A; SOILBSSURGO, hydrologic soil type B; SOILCSSURGO, hydrologic soil type C; KSATSSUR, average soil permeability; $\mu \mathrm{m} / \mathrm{s}$, micrometer per second; DRNFREQ, drainage frequency; RSD, relative stream density; NU, streamgage not used in development of regional-regression equations. Streamgage locations are shown in figure 1]

\begin{tabular}{|c|c|c|c|c|c|c|c|c|}
\hline $\begin{array}{c}\text { Map } \\
\text { number }\end{array}$ & $\begin{array}{c}\text { USGS } \\
\text { streamgage } \\
\text { number }\end{array}$ & $\begin{array}{l}\text { Low-flow } \\
\text { region }\end{array}$ & $\begin{array}{c}\text { Published } \\
\text { drainage area } \\
\left(\mathrm{mi}^{2}\right)\end{array}$ & $\begin{array}{c}\text { Observed BFI } \\
\text { (mean ratio of } \\
\text { base flow to } \\
\text { annual stream- } \\
\text { flow) }\end{array}$ & $\begin{array}{l}\text { Observed HYSEP } \\
\text { (median per- } \\
\text { centage of base } \\
\text { flow to annual } \\
\text { streamflow) }\end{array}$ & $\begin{array}{c}\text { Observed } \\
\text { TAU_ANN } \\
\text { (days) }\end{array}$ & $\begin{array}{c}\text { Observed } \\
\text { STREAM_VAR }\end{array}$ & $\begin{array}{c}\text { GIS } \\
\text { drainage area, } \\
\text { DRNAREA } \\
\left(\mathrm{mi}^{2}\right)\end{array}$ \\
\hline 105 & 05484650 & NU & 3,529 & .558 & 53.86 & 23.513 & .487 & $3,505.11$ \\
\hline 106 & 05484800 & NU & 78 & .506 & 49.88 & 21.035 & .627 & 76.76 \\
\hline 107 & 05484900 & NU & 3,625 & .548 & 52.59 & 22.624 & .518 & $3,602.79$ \\
\hline 108 & 05485640 & NU & 92.7 & 0.524 & 50.32 & 18.296 & 0.611 & 91.35 \\
\hline 109 & 05486000 & Northwest & 349 & .373 & 39.07 & 19.443 & .786 & 349.31 \\
\hline 110 & 05486490 & Southern & 503 & .373 & 37.71 & 24.623 & .637 & 489.37 \\
\hline 111 & 05487470 & Southern & 460 & .230 & 24.19 & 18.188 & .772 & 457.59 \\
\hline 112 & 05487540 & Southern & 6.78 & .715 & 67.35 & 24.188 & .594 & 6.77 \\
\hline 113 & 05487550 & Southern & 20.3 & .619 & 58.86 & 25.493 & .605 & 20.25 \\
\hline 114 & 05487980 & Southern & 342 & .218 & 22.77 & 17.405 & .763 & 339.86 \\
\hline 115 & 05488000 & Southern & 380 & .216 & 20.76 & 14.469 & .892 & 376.74 \\
\hline 116 & 05488200 & Southern & 90.1 & .252 & 26.66 & 14.710 & .853 & 90.66 \\
\hline 117 & 05489000 & Southern & 374 & .225 & 23.31 & 19.575 & .775 & 371.90 \\
\hline 118 & 05491000 & Southern & 105 & .214 & 21.17 & 13.111 & .813 & 106.25 \\
\hline 119 & 05494300 & Southern & 87.7 & .201 & 22.90 & 17.032 & .759 & 87.31 \\
\hline 120 & 05495000 & Southern & 400 & .198 & 20.52 & 14.114 & .798 & 395.71 \\
\hline 121 & 05495500 & Southern & 349 & .144 & 15.25 & 16.011 & .861 & 349.00 \\
\hline 122 & 05496000 & Southern & 393 & .165 & 17.85 & 13.965 & .810 & 398.00 \\
\hline 123 & 05497000 & Southern & 452 & .214 & 22.53 & 15.865 & .712 & 443.61 \\
\hline 124 & 05498000 & Southern & 393 & .185 & 19.74 & 13.536 & .806 & 386.68 \\
\hline 125 & 05500000 & Southern & 620 & .180 & 18.70 & 12.892 & .815 & 620.86 \\
\hline 126 & 05501000 & Southern & 373 & .182 & 18.39 & 14.246 & .752 & 366.62 \\
\hline 127 & 05502020 & Southern & 40.9 & .136 & 14.42 & 14.650 & .760 & 41.88 \\
\hline 128 & 05502040 & Southern & 72.7 & .243 & 23.59 & 16.265 & .767 & 73.06 \\
\hline 129 & 05503000 & Southern & 2.64 & .049 & 6.23 & 10.146 & .706 & 2.66 \\
\hline 130 & 05557000 & Southern & 86.7 & .472 & 45.88 & 19.859 & .844 & 85.97 \\
\hline 131 & 05568800 & Southern & 62.7 & .579 & 56.24 & 24.549 & .562 & 63.20 \\
\hline 132 & 05570000 & Southern & $1,635.8$ & .465 & 48.12 & 23.138 & .547 & $1,637.87$ \\
\hline 133 & 05584400 & Southern & 26.3 & .513 & 53.84 & 19.877 & .803 & 26.75 \\
\hline 134 & 05584500 & Southern & 655 & .330 & 33.99 & 17.038 & .702 & 663.48 \\
\hline 135 & 05585000 & Southern & 1293 & .300 & 30.93 & 19.241 & .657 & $1,312.34$ \\
\hline 136 & 06478518 & Northwest & 304 & .636 & 63.76 & 33.437 & .295 & 315.20 \\
\hline 137 & 06480400 & Northwest & 63.2 & .454 & 47.02 & 37.629 & .518 & 61.58 \\
\hline 138 & 06480650 & Northwest & 100 & .431 & 43.53 & 24.357 & .807 & 100.18 \\
\hline 139 & 06481500 & Northwest & 622 & .547 & 57.16 & 19.916 & .815 & 620.96 \\
\hline
\end{tabular}


Table 3. Hydrologic characteristics computed from observed streamflow and basin characteristics measured for streamgages evaluated in study.-Continued

[USGS, U.S. Geological Survey; mi² $^{2}$ square miles; BFI, base-flow index; HYSEP, hydrograph separation and analysis of base flow; TAU_ANN, annual base-flow-recession time constant; STREAM_VAR, streamflow-variability index; GIS, geographic information system; SOILASSURGO, hydrologic soil type A; SOILBSSURGO, hydrologic soil type B; SOILCSSURGO, hydrologic soil type C; KSATSSUR, average soil permeability; $\mu \mathrm{m} / \mathrm{s}$, micrometer per second; DRNFREQ, drainage frequency; RSD, relative stream density; NU, streamgage not used in development of regional-regression equations. Streamgage locations are shown in figure 1]

\begin{tabular}{|c|c|c|c|c|c|c|c|c|c|}
\hline $\begin{array}{c}\text { Map } \\
\text { number }\end{array}$ & $\begin{array}{l}\text { Interpolated BFI } \\
\text { from kriged grid } \\
\text { (ratio of mean } \\
\text { annual stream- } \\
\text { flow that is } \\
\text { base flow) }\end{array}$ & $\begin{array}{l}\text { Interpolated } \\
\text { TAU_ANN } \\
\text { from kriged } \\
\text { grid } \\
\text { (days) }\end{array}$ & $\begin{array}{c}\text { Interpolated } \\
\text { STREAM_VAR } \\
\text { from kriged } \\
\text { grid }\end{array}$ & $\begin{array}{l}\text { SOILA- } \\
\text { SSURGO } \\
\text { (percent } \\
\text { area) }\end{array}$ & $\begin{array}{l}\text { SOILB- } \\
\text { SSURGO } \\
\text { (percent } \\
\text { area) }\end{array}$ & $\begin{array}{l}\text { SOILC- } \\
\text { SSURGO } \\
\text { (percent } \\
\text { area) }\end{array}$ & $\begin{array}{c}\text { KSATSSUR } \\
(\mu \mathrm{m} / \mathrm{s})\end{array}$ & $\begin{array}{c}\text { DRNFREQ } \\
\text { (number of } \\
\text { first-order } \\
\text { streams/mi) }\end{array}$ & RSD \\
\hline 105 & .556 & 26.320 & .608 & .460 & 92.915 & 5.217 & 11.469 & .671 & .425 \\
\hline 106 & .551 & 24.581 & .651 & .000 & 90.300 & .000 & 10.392 & .951 & .366 \\
\hline 107 & .555 & 26.273 & .609 & .448 & 92.764 & 5.082 & 11.434 & .677 & .424 \\
\hline 108 & 0.551 & 21.203 & 0.678 & 0.317 & 96.453 & 0.000 & 9.488 & 0.712 & 0.436 \\
\hline 109 & .358 & 24.509 & .652 & .086 & 67.974 & 26.924 & 7.403 & 1.294 & .302 \\
\hline 110 & .373 & 23.364 & .673 & .149 & 59.308 & 35.717 & 6.566 & 1.759 & .294 \\
\hline 111 & .284 & 19.126 & .737 & .034 & 32.343 & 60.668 & 4.708 & 2.017 & .328 \\
\hline 112 & .543 & 20.823 & .689 & .000 & 92.020 & 7.582 & 7.985 & 1.182 & .403 \\
\hline 113 & .527 & 20.823 & .689 & .000 & 86.138 & 13.088 & 7.552 & 1.185 & .346 \\
\hline 114 & .232 & 17.790 & .751 & .022 & 12.724 & 80.411 & 3.691 & 2.204 & .323 \\
\hline 115 & .237 & 17.754 & .752 & .033 & 16.290 & 77.322 & 3.843 & 2.182 & .320 \\
\hline 116 & .283 & 17.395 & .755 & .000 & 19.186 & 76.902 & 3.701 & 1.886 & .342 \\
\hline 117 & .228 & 16.811 & .748 & .058 & 16.717 & 72.827 & 4.226 & 2.256 & .308 \\
\hline 118 & .255 & 15.291 & .743 & 1.361 & 12.081 & 59.974 & 4.320 & 1.534 & .282 \\
\hline 119 & .222 & 14.894 & .735 & .000 & 15.622 & 59.180 & 3.668 & 1.695 & .352 \\
\hline 120 & .213 & 14.905 & .748 & .090 & 11.521 & 62.291 & 3.952 & 4.579 & .843 \\
\hline 121 & .227 & 15.533 & .752 & .000 & 55.098 & 34.107 & 5.647 & 1.845 & .302 \\
\hline 122 & .197 & 14.295 & .757 & .000 & 5.718 & 63.130 & 3.412 & 1.334 & .282 \\
\hline 123 & .193 & 14.079 & .752 & .000 & 7.255 & 66.940 & 3.672 & 1.776 & .284 \\
\hline 124 & .188 & 13.365 & .753 & .000 & 4.711 & 66.293 & 3.525 & 1.797 & .282 \\
\hline 125 & .187 & 12.895 & .738 & .000 & 2.792 & 57.104 & 3.650 & 1.419 & .283 \\
\hline 126 & .186 & 12.740 & .733 & .000 & 5.205 & 41.973 & 3.738 & 1.432 & .299 \\
\hline 127 & .224 & 14.954 & .755 & .188 & 60.571 & 38.679 & 7.982 & 2.364 & .282 \\
\hline 128 & .210 & 14.922 & .757 & .108 & 69.003 & 29.994 & 9.093 & 2.382 & .283 \\
\hline 129 & .185 & 12.865 & .742 & .000 & .000 & 9.931 & 2.294 & 1.501 & .235 \\
\hline 130 & .560 & 31.914 & .580 & 2.630 & 96.162 & 1.157 & 16.034 & 1.012 & .237 \\
\hline 131 & .531 & 21.134 & .620 & .021 & 92.291 & 7.495 & 7.894 & 2.927 & .406 \\
\hline 132 & .513 & 22.260 & .647 & .040 & 89.465 & 8.774 & 8.172 & 1.834 & .358 \\
\hline 133 & .437 & 21.513 & .641 & .000 & 99.817 & .012 & 7.127 & 1.196 & .452 \\
\hline 134 & .327 & 18.150 & .703 & .000 & 76.463 & 19.606 & 6.980 & 1.491 & .330 \\
\hline 135 & .315 & 17.936 & .709 & .000 & 70.962 & 22.893 & 6.591 & 1.651 & .320 \\
\hline 136 & .620 & 35.821 & .409 & 7.867 & 88.477 & 2.304 & 17.163 & 1.240 & .257 \\
\hline 137 & .496 & 27.396 & .674 & .313 & 93.284 & 4.967 & 24.155 & 1.039 & .228 \\
\hline 138 & .496 & 27.396 & .674 & 1.733 & 95.314 & .761 & 18.963 & 1.118 & .189 \\
\hline 139 & .509 & 25.044 & .604 & 1.064 & 71.476 & 15.193 & 10.344 & .636 & .301 \\
\hline
\end{tabular}


Table 3. Hydrologic characteristics computed from observed streamflow and basin characteristics measured for streamgages evaluated in study.-Continued

[USGS, U.S. Geological Survey; $\mathrm{mi}^{2}$, square miles; BFI, base-flow index; HYSEP, hydrograph separation and analysis of base flow; TAU_ANN, annual base-flow-recession time constant; STREAM_VAR, streamflow-variability index; GIS, geographic information system; SOILASSURGO, hydrologic soil type A; SOILBSSURGO, hydrologic soil type B; SOILCSSURGO, hydrologic soil type C; KSATSSUR, average soil permeability; $\mu \mathrm{m} / \mathrm{s}$, micrometer per second; DRNFREQ, drainage frequency; RSD, relative stream density; NU, streamgage not used in development of regional-regression equations. Streamgage locations are shown in figure 1]

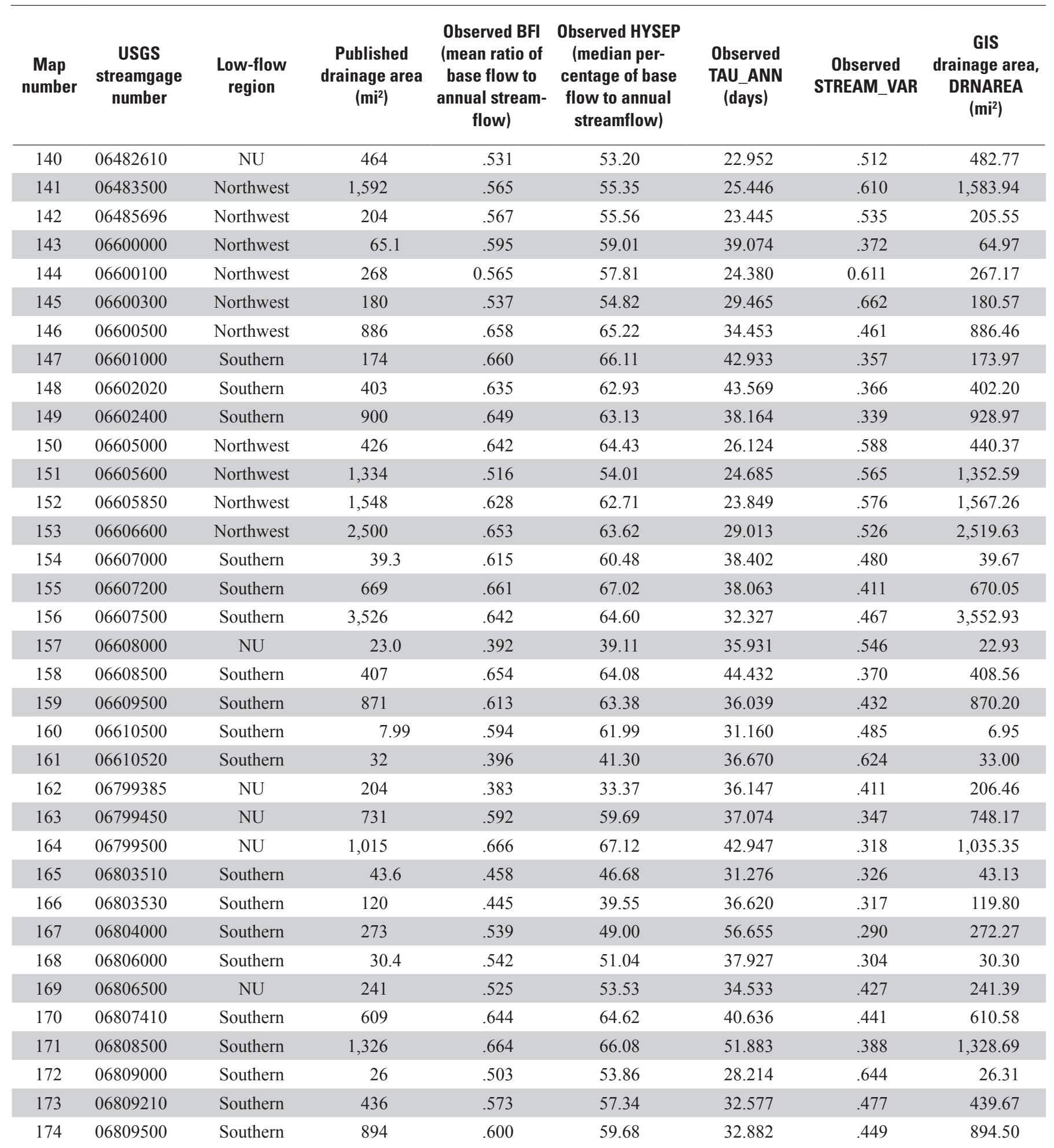


Table 3. Hydrologic characteristics computed from observed streamflow and basin characteristics measured for streamgages evaluated in study.-Continued

[USGS, U.S. Geological Survey; mi $^{2}$, square miles; BFI, base-flow index; HYSEP, hydrograph separation and analysis of base flow; TAU_ANN, annual base-flow-recession time constant; STREAM_VAR, streamflow-variability index; GIS, geographic information system; SOILASSURGO, hydrologic soil type A; SOILBSSURGO, hydrologic soil type B; SOILCSSURGO, hydrologic soil type C; KSATSSUR, average soil permeability; $\mu \mathrm{m} / \mathrm{s}$, micrometer per second; DRNFREQ, drainage frequency; RSD, relative stream density; NU, streamgage not used in development of regional-regression equations. Streamgage locations are shown in figure 1]

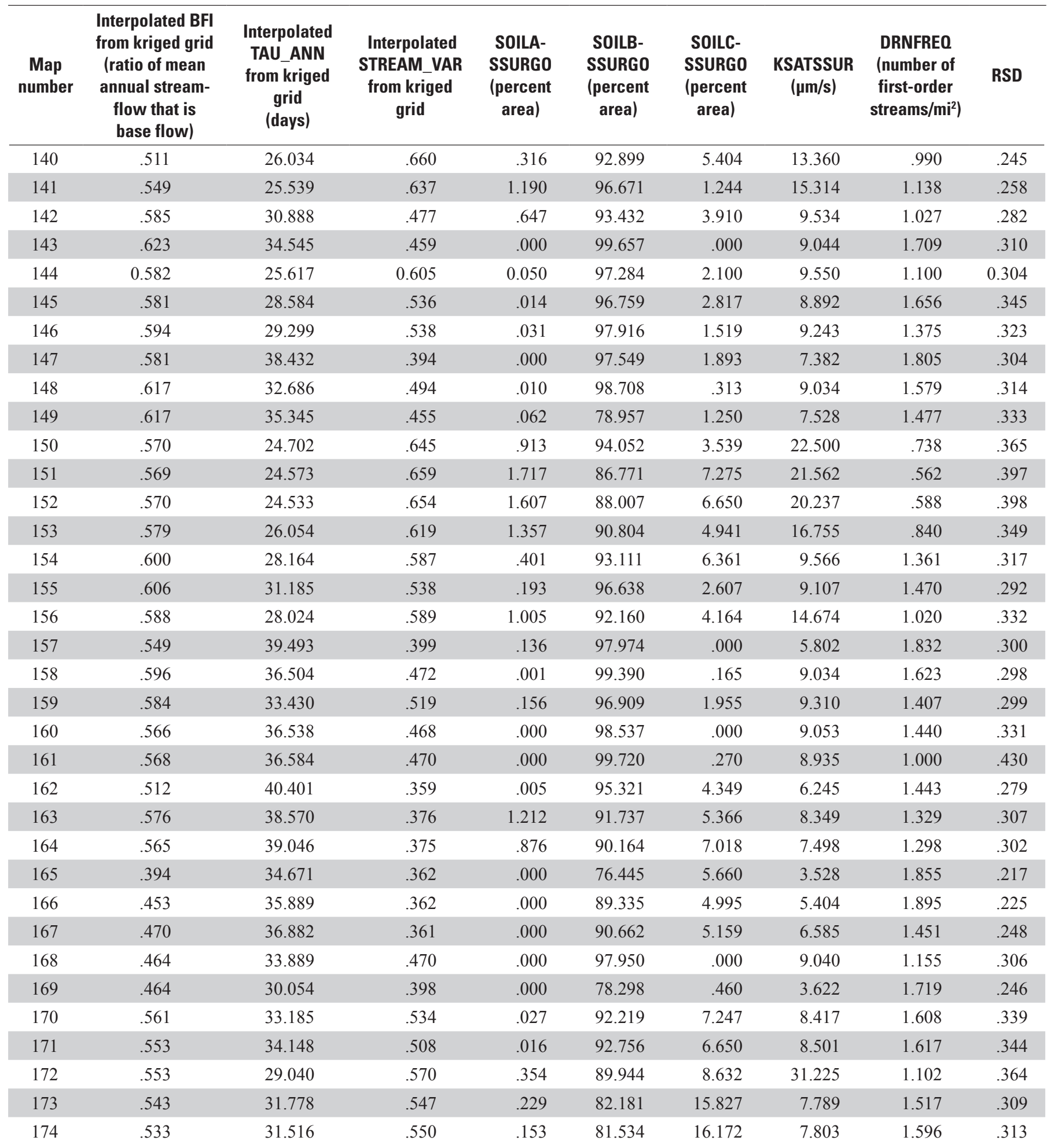


Table 3. Hydrologic characteristics computed from observed streamflow and basin characteristics measured for streamgages evaluated in study.-Continued

[USGS, U.S. Geological Survey; $\mathrm{mi}^{2}$, square miles; BFI, base-flow index; HYSEP, hydrograph separation and analysis of base flow; TAU_ANN, annual base-flow-recession time constant; STREAM_VAR, streamflow-variability index; GIS, geographic information system; SOILASSURGO, hydrologic soil type A; SOILBSSURGO, hydrologic soil type B; SOILCSSURGO, hydrologic soil type C; KSATSSUR, average soil permeability; $\mu \mathrm{m} / \mathrm{s}$, micrometer per second; DRNFREQ, drainage frequency; RSD, relative stream density; NU, streamgage not used in development of regional-regression equations. Streamgage locations are shown in figure 1]

\begin{tabular}{|c|c|c|c|c|c|c|c|c|}
\hline $\begin{array}{c}\text { Map } \\
\text { number }\end{array}$ & $\begin{array}{c}\text { USGS } \\
\text { streamgage } \\
\text { number }\end{array}$ & $\begin{array}{l}\text { Low-flow } \\
\text { region }\end{array}$ & $\begin{array}{l}\text { Published } \\
\text { drainage area } \\
\left(\mathrm{mi}^{2}\right)\end{array}$ & $\begin{array}{c}\text { Observed BFI } \\
\text { (mean ratio of } \\
\text { base flow to } \\
\text { annual stream- } \\
\text { flow) }\end{array}$ & $\begin{array}{l}\text { Observed HYSEP } \\
\text { (median per- } \\
\text { centage of base } \\
\text { flow to annual } \\
\text { streamflow) }\end{array}$ & $\begin{array}{c}\text { Observed } \\
\text { TAU_ANN } \\
\text { (days) }\end{array}$ & $\begin{array}{c}\text { Observed } \\
\text { STREAM_VAR }\end{array}$ & $\begin{array}{c}\text { GIS } \\
\text { drainage area, } \\
\text { DRNAREA } \\
\left(\mathrm{mi}^{2}\right)\end{array}$ \\
\hline 175 & 06810000 & Southern & 2,806 & .616 & 62.73 & 39.348 & .419 & $2,809.05$ \\
\hline 176 & 06810500 & NU & 218 & .316 & 30.75 & 20.473 & .534 & 209.13 \\
\hline 177 & 06811500 & Southern & 792 & .398 & 39.78 & 29.345 & .398 & 793.13 \\
\hline 178 & 06811840 & Southern & 49.3 & .417 & 43.52 & 26.814 & .798 & 50.12 \\
\hline 179 & 06813000 & Southern & 508 & .460 & 46.14 & 29.581 & .574 & 479.35 \\
\hline 180 & 06814500 & Southern & 548 & 0.300 & 30.98 & 25.518 & 0.422 & 548.99 \\
\hline 181 & 06815000 & NU & 1,339 & .306 & 31.46 & 23.846 & .488 & ND \\
\hline 182 & 06815500 & Southern & 188 & .407 & 41.30 & 31.576 & .331 & 186.57 \\
\hline 183 & 06816000 & Southern & 4.90 & .475 & 46.92 & 31.879 & .432 & 4.96 \\
\hline 184 & 06817000 & Southern & 762 & .445 & 43.17 & 28.221 & .525 & 761.32 \\
\hline 185 & 06817500 & Southern & 1,240 & .326 & 33.62 & 27.010 & .575 & $1,293.70$ \\
\hline 186 & 06817700 & Southern & 1,380 & .454 & 45.09 & 26.190 & .537 & $1,516.23$ \\
\hline 187 & 06818750 & Southern & 217 & .296 & 31.70 & 26.444 & .669 & 215.75 \\
\hline 188 & 06818900 & Southern & 486 & .215 & 22.86 & 15.810 & .618 & 485.80 \\
\hline 189 & 06819185 & Southern & 85.4 & .239 & 22.65 & 21.377 & .821 & 85.78 \\
\hline 190 & 06819190 & Southern & 92.1 & .178 & 18.39 & 17.623 & .840 & 92.04 \\
\hline 191 & 06819500 & Southern & 500 & .204 & 22.35 & 16.698 & .791 & 491.03 \\
\hline 192 & 06820000 & Southern & 6.00 & .155 & 17.65 & 12.163 & .465 & 6.06 \\
\hline 193 & 06896500 & Southern & 5.58 & .147 & 15.48 & 12.893 & .433 & 5.45 \\
\hline 194 & 06897000 & Southern & 95.0 & .166 & 17.18 & 10.910 & .968 & 90.80 \\
\hline 195 & 06897500 & Southern & 2,250 & .248 & 23.79 & 20.843 & .695 & $2,245.71$ \\
\hline 196 & 06897950 & Southern & 52.5 & .168 & 16.56 & 13.600 & 1.024 & 52.26 \\
\hline 197 & 06898000 & Southern & 701 & .285 & 29.20 & 18.442 & .688 & 695.38 \\
\hline 198 & 06898100 & Southern & 891 & .354 & 33.08 & 25.582 & .583 & 856.10 \\
\hline 199 & 06898400 & Southern & 104 & .147 & 15.77 & 19.759 & .828 & 101.79 \\
\hline 200 & 06898500 & Southern & 246 & .119 & 4.81 & 10.531 & .227 & 250.58 \\
\hline 201 & 06899000 & Southern & 494 & .142 & 14.91 & 17.258 & .794 & 479.87 \\
\hline 202 & 06900000 & Southern & 225 & .235 & 22.24 & 16.489 & .699 & 231.89 \\
\hline 203 & 06901500 & Southern & 550 & .193 & 20.20 & 17.735 & .736 & 554.36 \\
\hline 204 & 06902500 & Southern & 2.51 & .099 & 12.75 & 9.420 & .458 & 2.54 \\
\hline 205 & 06903400 & Southern & 182 & .182 & 18.98 & 12.043 & .958 & 185.68 \\
\hline 206 & 06903500 & Southern & 13.2 & .235 & 19.73 & 20.883 & .509 & 13.30 \\
\hline 207 & 06903700 & Southern & 168 & .184 & 20.02 & 13.825 & .829 & 169.52 \\
\hline 208 & 06904500 & Southern & 1,370 & .238 & 24.70 & 12.487 & .810 & $1,364.30$ \\
\hline
\end{tabular}


Table 3. Hydrologic characteristics computed from observed streamflow and basin characteristics measured for streamgages evaluated in study.-Continued

[USGS, U.S. Geological Survey; mi $^{2}$, square miles; BFI, base-flow index; HYSEP, hydrograph separation and analysis of base flow; TAU_ANN, annual base-flow-recession time constant; STREAM_VAR, streamflow-variability index; GIS, geographic information system; SOILASSURGO, hydrologic soil type A; SOILBSSURGO, hydrologic soil type B; SOILCSSURGO, hydrologic soil type C; KSATSSUR, average soil permeability; $\mu \mathrm{m} / \mathrm{s}$, micrometer per second; DRNFREQ, drainage frequency; RSD, relative stream density; NU, streamgage not used in development of regional-regression equations. Streamgage locations are shown in figure 1]

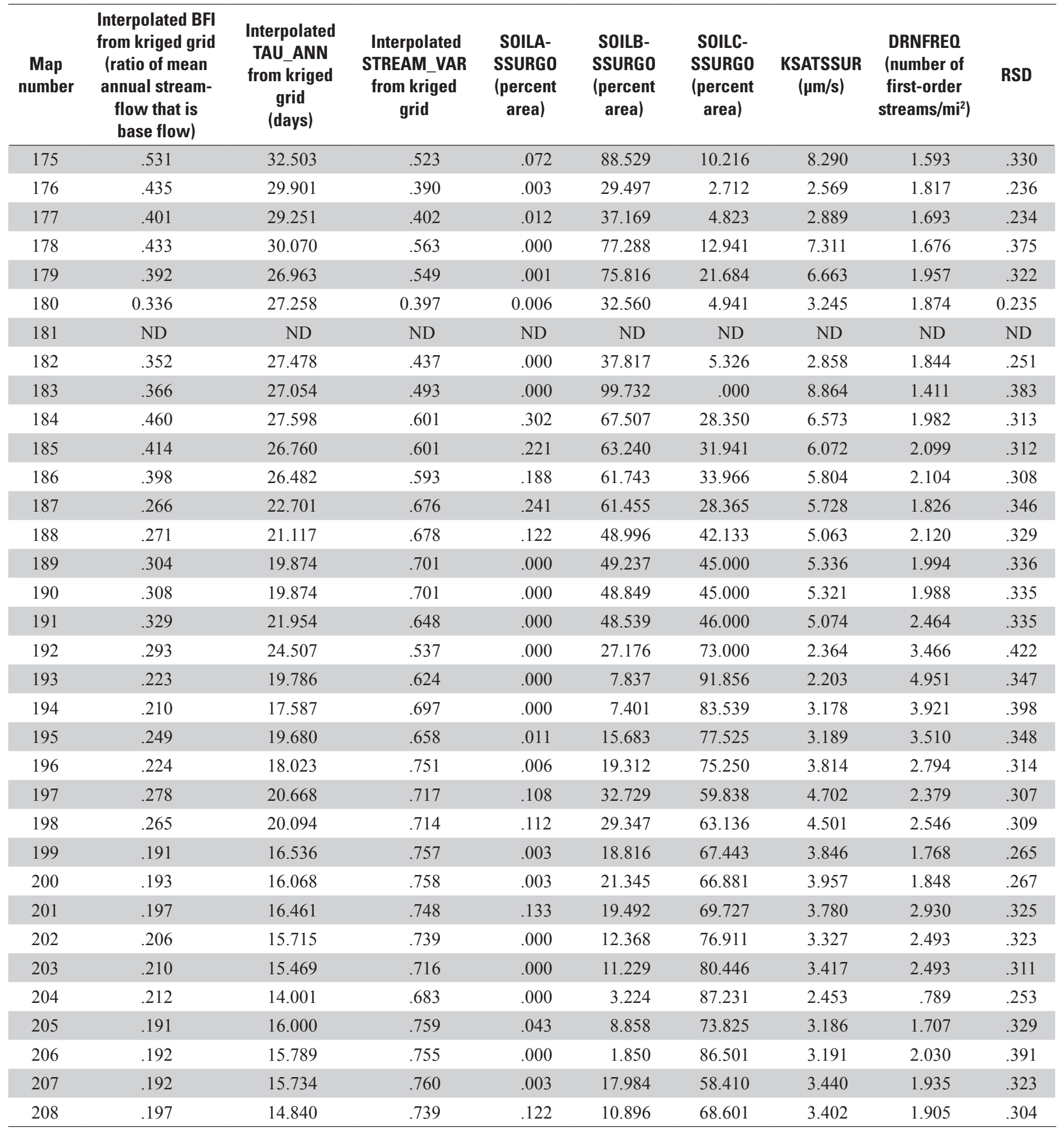


Table 5. Basin characteristics tested for significance in developing regression equations.

[USGS, U.S. Geological Survey; DEM, digital elevation model; WBD, watershed boundary dataset; m, meters; 24K, 1:24,000 scale; BFI, base-flow index; HYSEP, hydrograph separation and analysis; TAU_ANN, annual base-flow-recession time constant; NHD, national hydrography dataset; NRSC, Natural Resource Conservation Service; SSURGO, Soil Survey Geographic database; IDNR, Iowa Department of Natural Resources; PRISM, parameter-elevation regressions on independent slopes model]

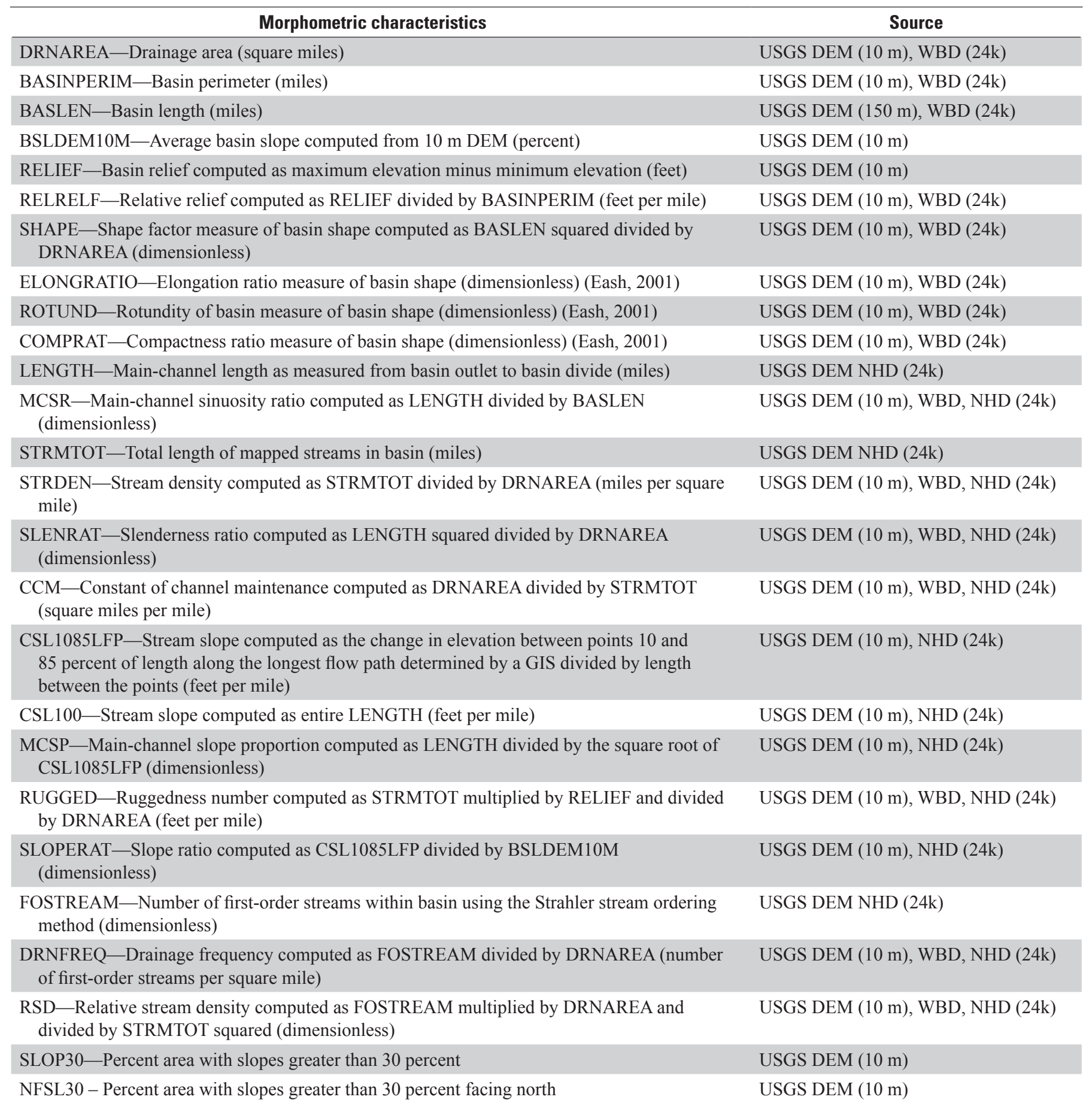


Table 5. Basin characteristics tested for significance in developing regression equations.-Continued

[USGS, U.S. Geological Survey; DEM, digital elevation model; WBD, watershed boundary dataset; m, meters; 24K, 1:24,000 scale; BFI, base-flow index; HYSEP, hydrograph separation and analysis; TAU_ANN, annual base-flow-recession time constant; NHD, national hydrography dataset; NRSC, Natural Resource Conservation Service; SSURGO, Soil Survey Geographic database; IDNR, Iowa Department of Natural Resources; PRISM, parameter-elevation regressions on independent slopes model]

\section{Hydrologic characteristics}

BFI-Base-flow index is the mean ratio of base flow to annual streamflow (dimensionless) (Wahl and Wahl, 1988)

HYSEP-Hydrograph separation and analysis is the median percentage of baseflow to annual streamflow (percent) (Sloto and Crouse, 1996)

TAU_ANN-Annual base-flow-recession time constant computes the rate of baseflow recession between storm events (days) (Eng and Milly, 2007)

TAU_1012 - Seasonal base-flow-recession time constant computed for October to December (days)

STREAM_VAR - Streamflow-variability index is a measure of the steepness of the slope of a duration curve (dimensionless) (Koltun and Whitehead, 2002)

\section{Pedologic/geologic/land-use characteristics}

SOILASSURGO - Percent area underlain by hydrologic soil type A (percent area)

SOILBSSURGO_-Percent area underlain by hydrologic soil type B (percent area)

SOILCSSURGO - Percent area underlain by hydrologic soil type C (percent area)

SOILDSSURGO - Percent area underlain by hydrologic soil type D (percent area)

SAND_Percent volume of sand content of soil (percent volume)

CLAY - Percent volume of clay content of soil (percent volume)

KSATSSUR - Average soil permeability or saturated hydraulic conductivity of soil (micrometers per second)

DESMOIN_-Percent area of basin within Des Moines Lobe landform region (percent area)

ROWCROP_Percent area of cultivated crops (percent area), see <http://www.mrlc.gov/ index.php> and Homer and others (2004)

\begin{tabular}{|c|c|}
\hline Climatic characteristics & Source \\
\hline $\begin{array}{l}\text { PRECIP_Mean annual precipitation 1971-2000, see <http://www.prism.oregonstate.edu/> } \\
\text { (inches) }\end{array}$ & PRISM Climate Group \\
\hline PRC1-Mean January precipitation 1971-2000 (inches) & PRISM Climate Group \\
\hline FEBAVPRE-Mean February precipitation 1971-2000 (inches) & PRISM Climate Group \\
\hline MARAVPRE-Mean March precipitation 1971-2000 (inches) & PRISM Climate Group \\
\hline PRC4 - Mean April precipitation 1971-2000 (inches) & PRISM Climate Group \\
\hline MAYAVEPRE- Mean May precipitation 1971-2000 (inches) & PRISM Climate Group \\
\hline JUNEAVPRE-Mean June precipitation 1971-2000 (inches) & PRISM Climate Group \\
\hline JULYAVPRE-Mean July precipitation 1971-2000 (inches) & PRISM Climate Group \\
\hline PRC8-Mean August precipitation 1971-2000 (inches) & PRISM Climate Group \\
\hline SEPAVPRE-Mean September precipitation 1971-2000 (inches) & PRISM Climate Group \\
\hline OCTAVPRE-Mean October precipitation 1971-2000 (inches) & PRISM Climate Group \\
\hline NOVAVPRE-Mean November precipitation 1971-2000 (inches) & PRISM Climate Group \\
\hline DECAVPRE-Mean December precipitation 1971-2000 (inches) & PRISM Climate Group \\
\hline PRC10_12-Mean October to December precipitation 1971-2000 (inches) & PRISM Climate Group \\
\hline
\end{tabular}

Source

USGS kriged BFI grid

USGS kriged HYSEP grid

USGS kriged TAU_ANN grid

USGS kriged TAU_1012 grid

USGS kriged STREAM VAR grid

Source

NRCS SSURGO Web Soil Survey

NRCS SSURGO Web Soil Survey

NRCS SSURGO Web Soil Survey

NRCS SSURGO Web Soil Survey NRCS SSURGO Web Soil Survey

NRCS SSURGO Web Soil Survey

NRCS SSURGO Web Soil Survey

Iowa Geological \& Water Survey, IDNR grid

2001 National Landcover Database grid 
Table 14. Range of basin-characteristic values used to develop selected low-flow frequency and harmonic-mean-flow regression equations for unregulated streams in lowa.

[DRNAREA, GIS drainage area; TAU_ANN, annual base-flow-recession time constant; KSATSSUR, average soil permeability; STREAM_VAR, streamflowvariability index; DRNFREQ, drainage frequency; M1D10Y, annual 1-day mean low flow for a recurrence interval of 10 years; NA, not applicable; M7D10Y, annual 7-day mean low flow for a recurrence interval of 10 years; M30D10Y, annual 30-day mean low flow for a recurrence interval of 10 years; M30D5Y, annual 30-day mean low flow for a recurrence interval of 5 years; M1D10Y1012, seasonal (October through December) 1-day mean low flow for a recurrence interval of 10 years; M7D10Y1012, seasonal (October through December) 7-day mean low flow for a recurrence interval of 10 years; QAH, harmonic mean flow; BFI, base-flow index; SOILASSURGO, hydrologic soil type A; RSD, relative stream density; SOILBSSURGO, hydrologic soil type B; SOILCSSURGO, hydrologic soil type C; GLS, generalized least-squares regression]

\begin{tabular}{|c|c|c|c|c|c|c|c|c|c|c|}
\hline \multicolumn{11}{|c|}{ Northeast Region } \\
\hline \multirow[t]{2}{*}{ Statistic equation } & \multicolumn{2}{|c|}{ DRNAREA } & \multicolumn{2}{|c|}{ TAU_ANN } & \multicolumn{2}{|c|}{ KSATSSUR } & \multicolumn{2}{|c|}{ STREAM_VAR } & \multicolumn{2}{|c|}{ DRNFREQ } \\
\hline & Minimum & Maximum & Minimum & Maximum & Minimum & Maximum & Minimum & Maximum & Minimum & Maximum \\
\hline M7D10Y & 1.40 & $6,505.95$ & 21.2 & 61.2 & 8.260 & 29.0 & NA & NA & NA & NA \\
\hline M30D10Y & 1.40 & $6,505.95$ & 21.2 & 61.2 & 8.260 & 29.0 & NA & NA & NA & NA \\
\hline M1D10Y1012 & 1.40 & $6,505.95$ & 21.2 & 61.2 & 8.260 & 29.0 & NA & NA & NA & NA \\
\hline M7D10Y1012 & 1.40 & $6,505.95$ & 21.2 & 61.2 & 8.260 & 29.0 & NA & NA & NA & NA \\
\hline QAH & 1.40 & $6,505.95$ & NA & NA & NA & NA & 0.206 & 0.610 & 0.295 & 2.78 \\
\hline \multicolumn{11}{|c|}{ Northwest Region } \\
\hline & \multicolumn{2}{|c|}{ DRNAREA } & \multicolumn{2}{|c|}{ BFI } & \multicolumn{2}{|c|}{ SOILASSURGO } & \multicolumn{2}{|c|}{ TAU_ANN } & \multicolumn{2}{|c|}{ RSD } \\
\hline M30D10Y & 23.41 & $5,463.88$ & .358 & .623 & .000 & 7.87 & NA & NA & NA & NA \\
\hline M30D5Y & 23.41 & $5,463.88$ & .358 & .623 & .000 & 7.87 & NA & NA & NA & NA \\
\hline M1D10Y1012 & 23.41 & $5,463.88$ & .358 & .623 & .000 & 7.87 & NA & NA & NA & NA \\
\hline M7D10Y1012 & 23.41 & $5,463.88$ & .358 & .623 & .000 & 7.87 & NA & NA & NA & NA \\
\hline QAH & 23.41 & $5,463.88$ & NA & NA & NA & NA & 21.2 & 35.8 & 0.189 & 0.511 \\
\hline \multicolumn{11}{|c|}{ Southern Region } \\
\hline & \multicolumn{2}{|c|}{ DRNAREA } & \multicolumn{2}{|c|}{ STREAM_VAR } & \multicolumn{2}{|c|}{ SOILBSSURGO } & \multicolumn{2}{|c|}{ BFI } & \multicolumn{2}{|c|}{ SOILCSSURGO } \\
\hline & Minimum & Maximum & Minimum & Maximum & Minimum & Maximum & Minimum & Maximum & Minimum & Maximum \\
\hline Logistic M30D5Y & 2.54 & $7,782.62$ & NA & NA & NA & NA & .185 & .617 & NA & NA \\
\hline GLS M30D5Y & 2.94 & $7,782.62$ & .361 & .760 & 2.79 & 99.8 & NA & NA & NA & NA \\
\hline $\begin{array}{l}\text { Logistic } \\
\qquad \text { M1D10Y1012 }\end{array}$ & 2.54 & $7,782.62$ & NA & NA & NA & NA & .185 & .617 & NA & NA \\
\hline GLS M1D10Y1012 & 6.77 & $7,782.62$ & .361 & .760 & 2.79 & 99.7 & NA & NA & NA & NA \\
\hline $\begin{array}{l}\text { Logistic } \\
\text { M7D10Y1012 }\end{array}$ & 2.54 & $7,782.62$ & NA & NA & NA & NA & .185 & .617 & NA & NA \\
\hline GLS M7D10Y1012 & 6.77 & $7,782.62$ & .361 & .760 & 2.79 & 99.7 & NA & NA & NA & NA \\
\hline QAH & 2.54 & $7,782.62$ & .361 & .760 & NA & NA & NA & NA & 0.000 & 91.9 \\
\hline
\end{tabular}


Table 15. Values needed to determine the 90-percent prediction intervals for estimates obtained from regional regression equations using covariance matrices in lowa.

$[t$, the critical value from Students t-distribution for the 90-percent probability used in equation 11; MEV, regression model error variance used in equation 12; $\mathrm{U}$, covariance matrix as used in equation 12; M1D10Y, annual 1-day mean low flow for a recurrence interval of 10 years; Intercept, $y$-axis intercept of regression equation; DRNAREA, GIS drainage area; TAU_ANN, annual base-flow-recession time constant; KSATSSUR, average soil permeability; M7D10Y, annual 7-day mean low flow for a recurrence interval of 10 years; M30D10Y, annual 30-day mean low flow for a recurrence interval of 10 years; M30D5Y, annual 30-day mean low flow for a recurrence interval of 5 years; M1D10Y1012, seasonal (October through December) 1-day mean low flow for a recurrence interval of 10 years; M7D10Y1012, seasonal (October through December) 7-day mean low flow for a recurrence interval of 10 years; QAH, harmonic mean flow; STREAM_VAR, streamflow-variability index; DRNFREQ, drainage frequency; BFI, base-flow index; SOILASSURGO, hydrologic soil type A; RSD, relative stream density; SOILBSSURGO, hydrologic soil type B; SOILCSSURGO, hydrologic soil type C]

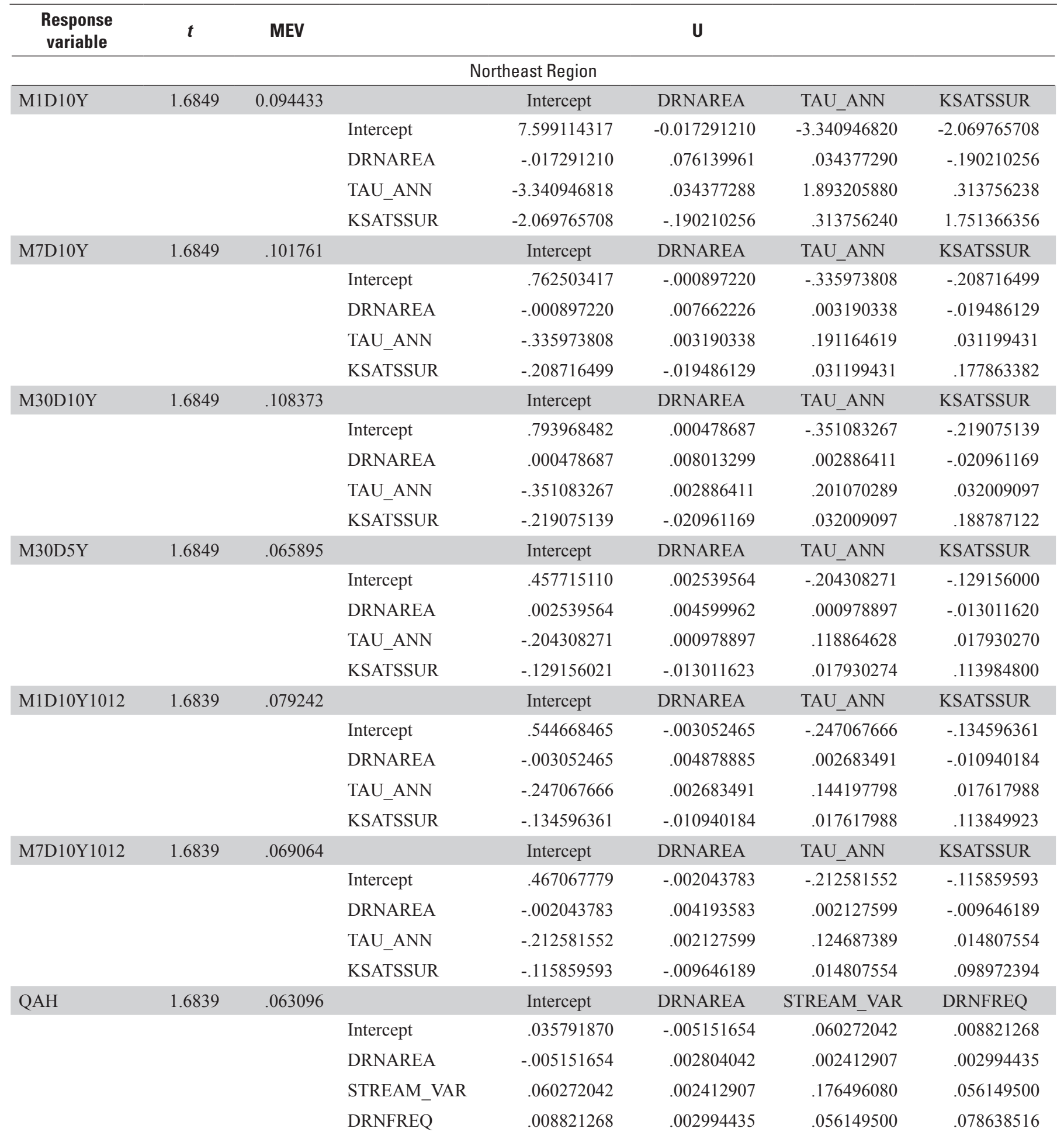


Table 15. Values needed to determine the 90-percent prediction intervals for estimates obtained from regional regression equations using covariance matrices in lowa.-Continued

$[t$, the critical value from Students t-distribution for the 90-percent probability used in equation 11; MEV, regression model error variance used in equation 12; $\mathrm{U}$, covariance matrix as used in equation 12; M1D10Y, annual 1-day mean low flow for a recurrence interval of 10 years; Intercept, y-axis intercept of regression equation; DRNAREA, GIS drainage area; TAU_ANN, annual base-flow-recession time constant; KSATSSUR, average soil permeability; M7D10Y, annual 7-day mean low flow for a recurrence interval of 10 years; M30D10Y, annual 30-day mean low flow for a recurrence interval of 10 years; M30D5Y, annual 30-day mean low flow for a recurrence interval of 5 years; M1D10Y1012, seasonal (October through December) 1-day mean low flow for a recurrence interval of 10 years; M7D10Y1012, seasonal (October through December) 7-day mean low flow for a recurrence interval of 10 years; QAH, harmonic mean flow; STREAM_VAR, streamflow-variability index; DRNFREQ, drainage frequency; BFI, base-flow index; SOILASSURGO, hydrologic soil type A; RSD, relative stream density; SOILBSSURGO, hydrologic soil type B; SOILCSSURGO, hydrologic soil type C]

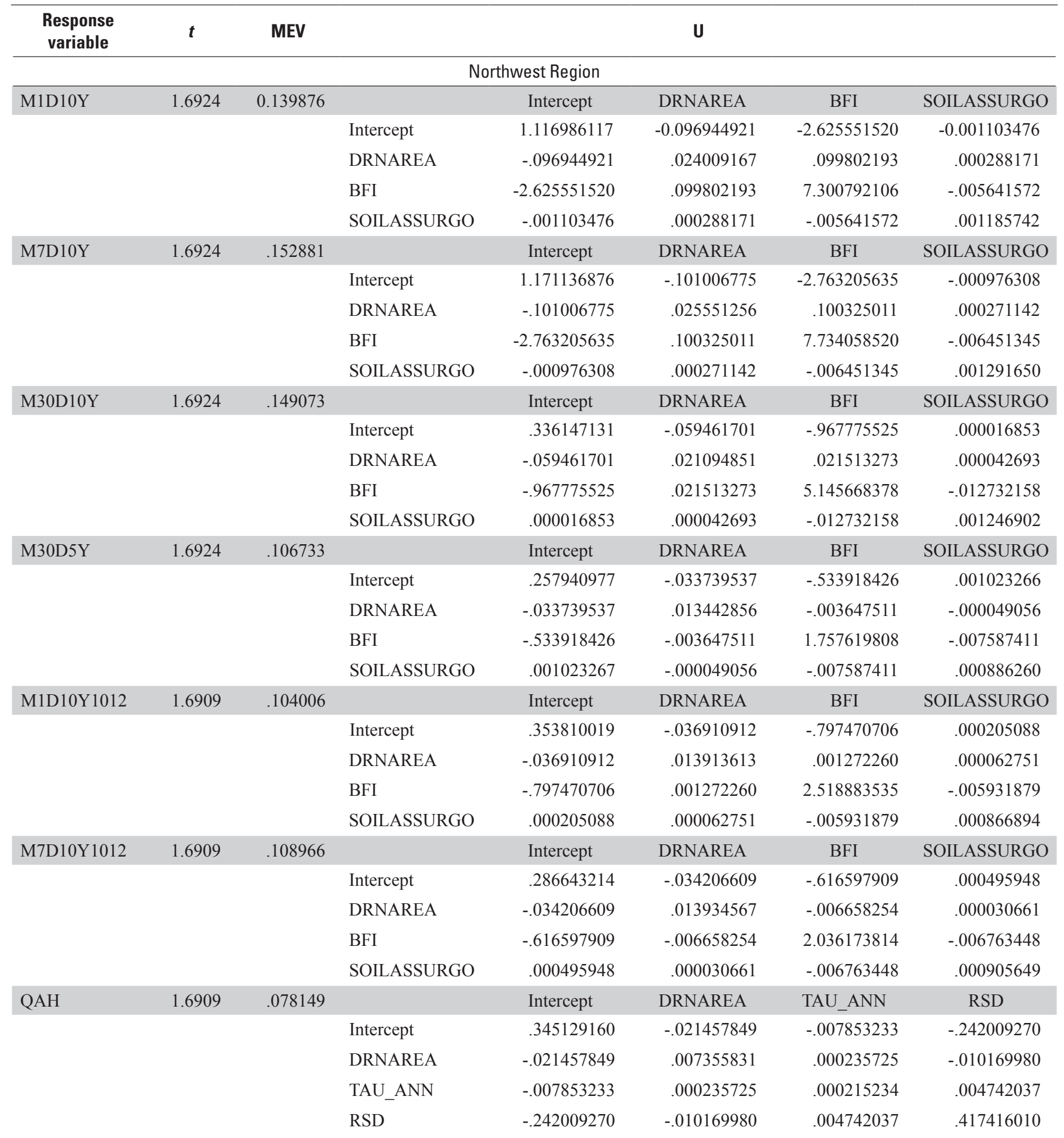


Table 15. Values needed to determine the 90-percent prediction intervals for estimates obtained from regional regression equations using covariance matrices in lowa.-Continued

$[t$, the critical value from Students t-distribution for the 90-percent probability used in equation 11; MEV, regression model error variance used in equation 12; $\mathrm{U}$, covariance matrix as used in equation 12; M1D10Y, annual 1-day mean low flow for a recurrence interval of 10 years; Intercept, y-axis intercept of regression equation; DRNAREA, GIS drainage area; TAU_ANN, annual base-flow-recession time constant; KSATSSUR, average soil permeability; M7D10Y, annual 7-day mean low flow for a recurrence interval of 10 years; M30D10Y, annual 30-day mean low flow for a recurrence interval of 10 years; M30D5Y, annual 30-day mean low flow for a recurrence interval of 5 years; M1D10Y1012, seasonal (October through December) 1-day mean low flow for a recurrence interval of 10 years; M7D10Y1012, seasonal (October through December) 7-day mean low flow for a recurrence interval of 10 years; QAH, harmonic mean flow; STREAM_VAR, streamflow-variability index; DRNFREQ, drainage frequency; BFI, base-flow index; SOILASSURGO, hydrologic soil type A; RSD, relative stream density; SOILBSSURGO, hydrologic soil type B; SOILCSSURGO, hydrologic soil type C]

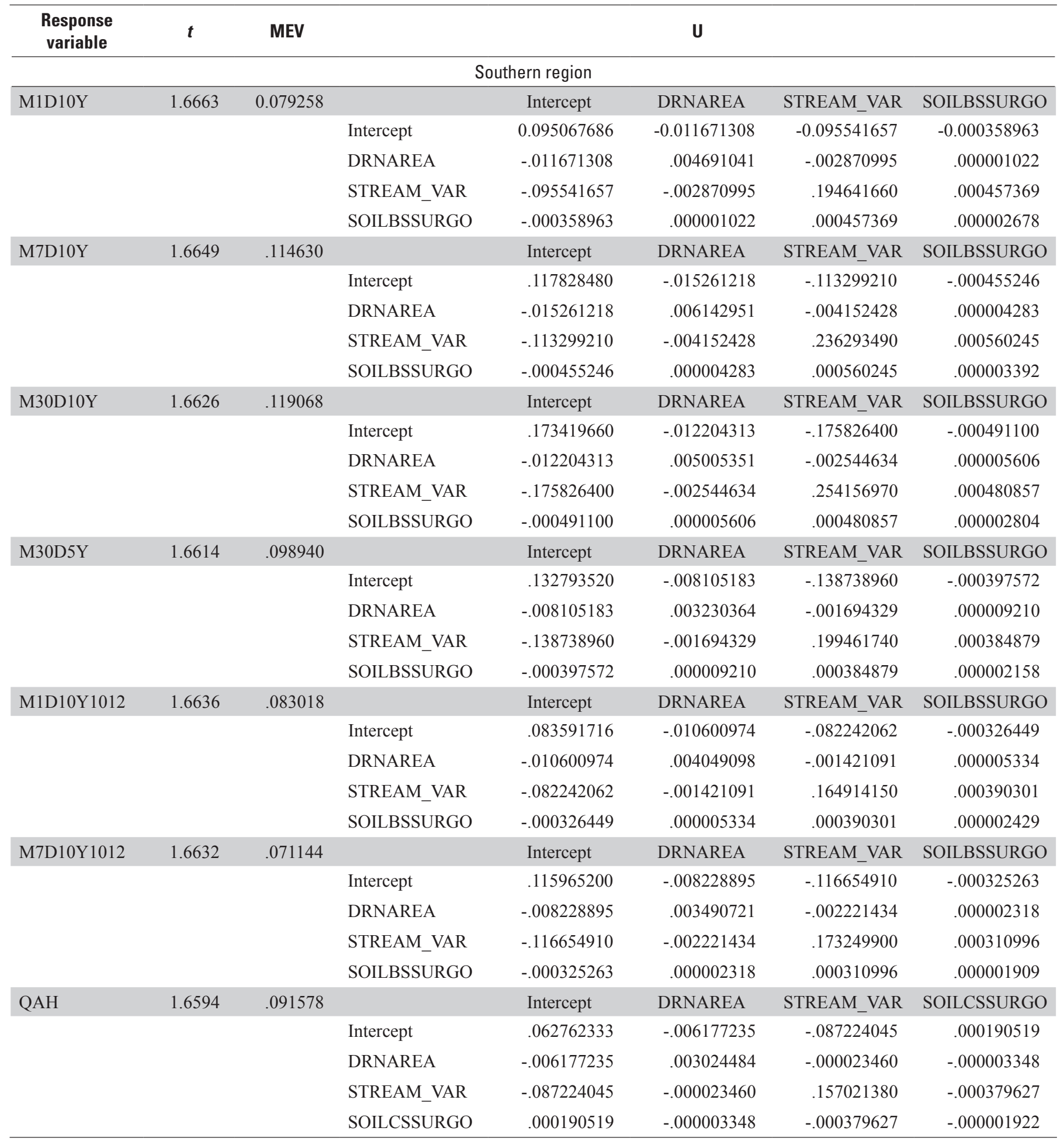




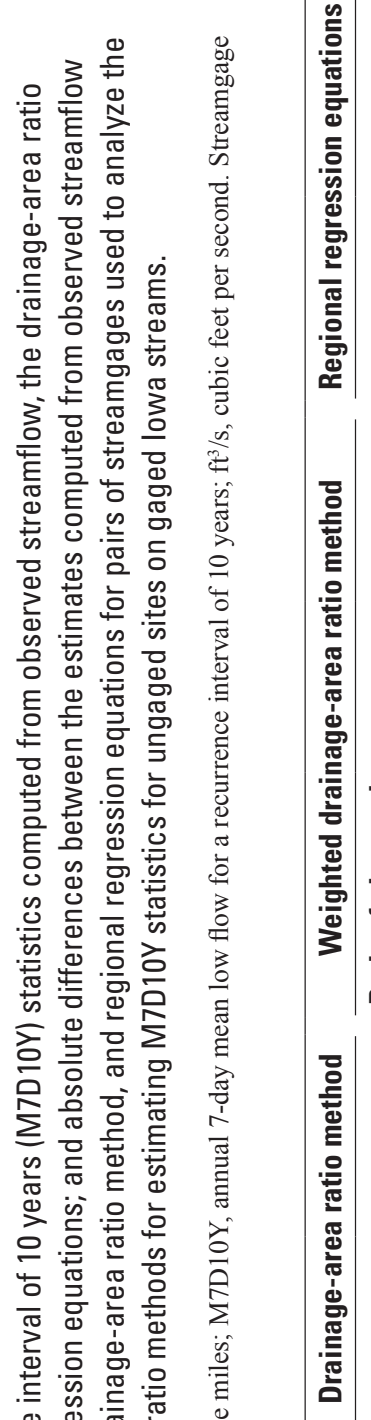

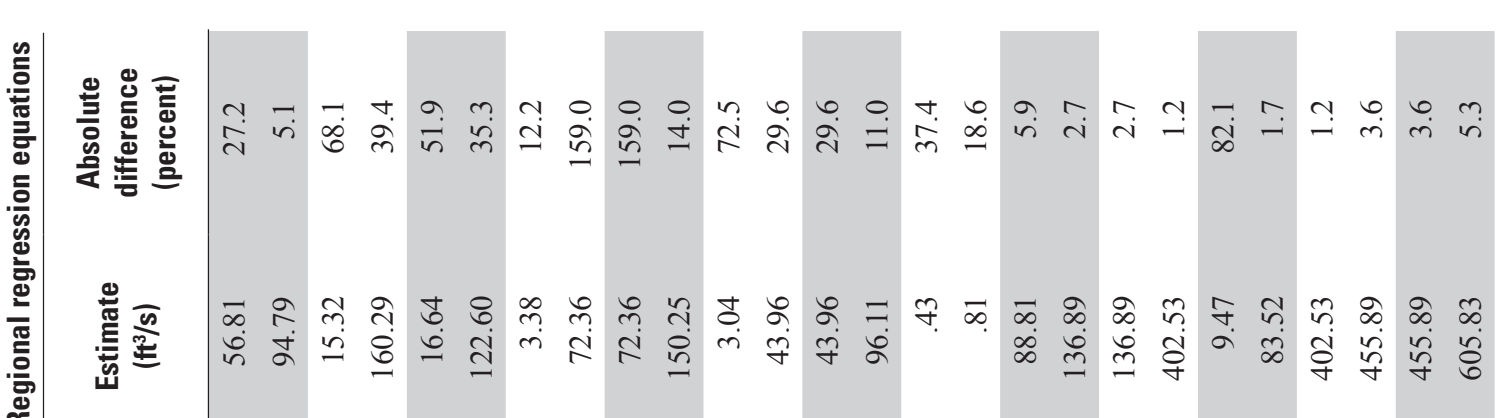

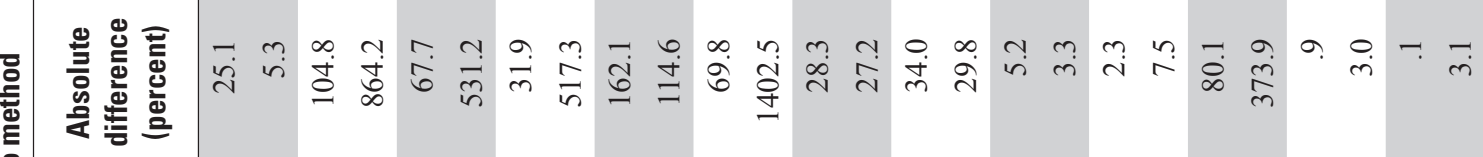

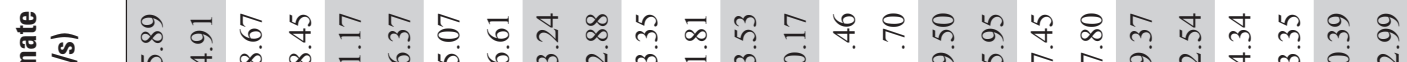

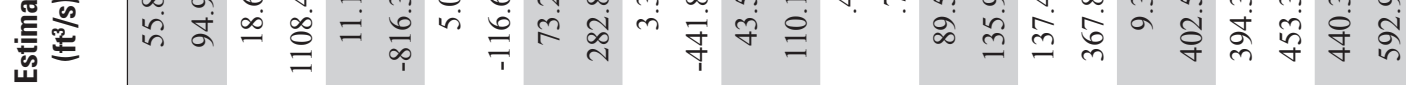
焉

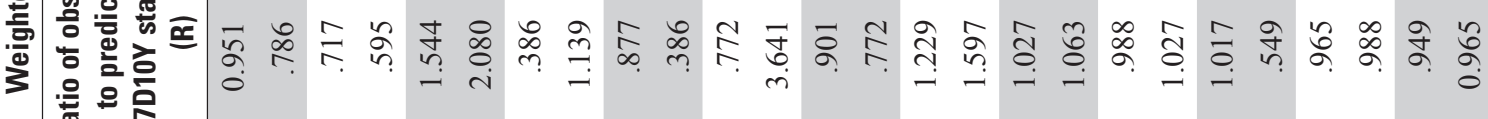

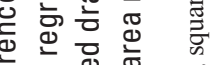

票

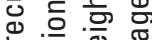

ब

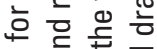

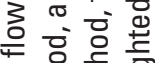

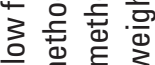

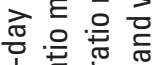

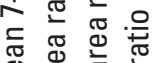

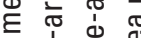

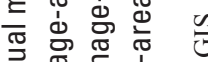
总施

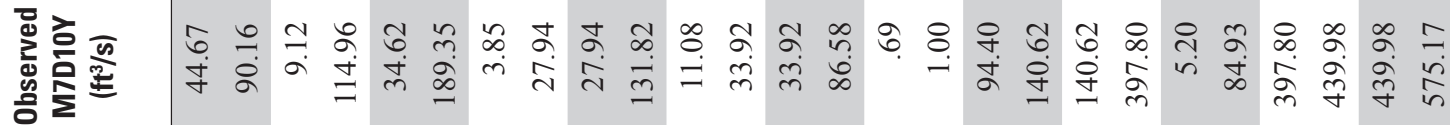

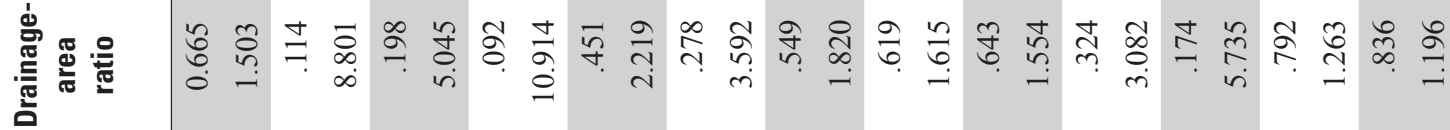

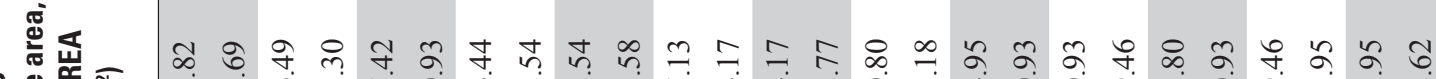

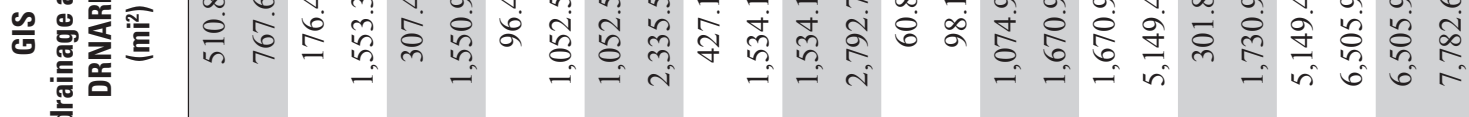

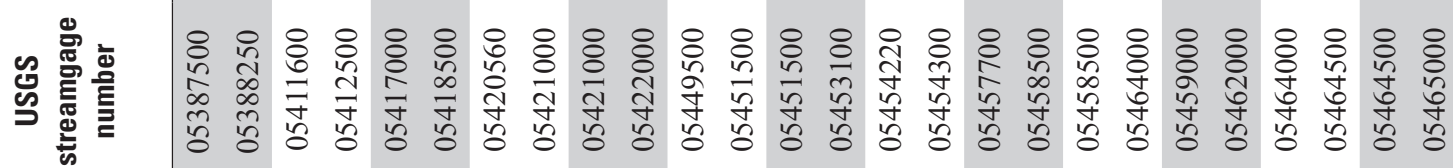

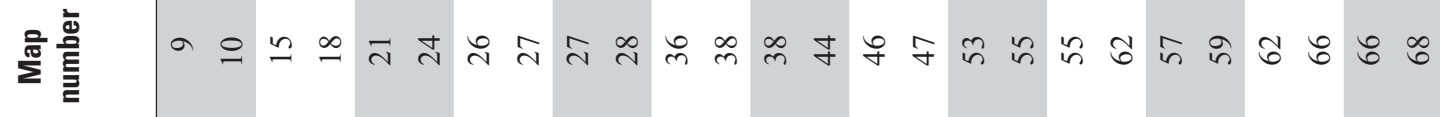




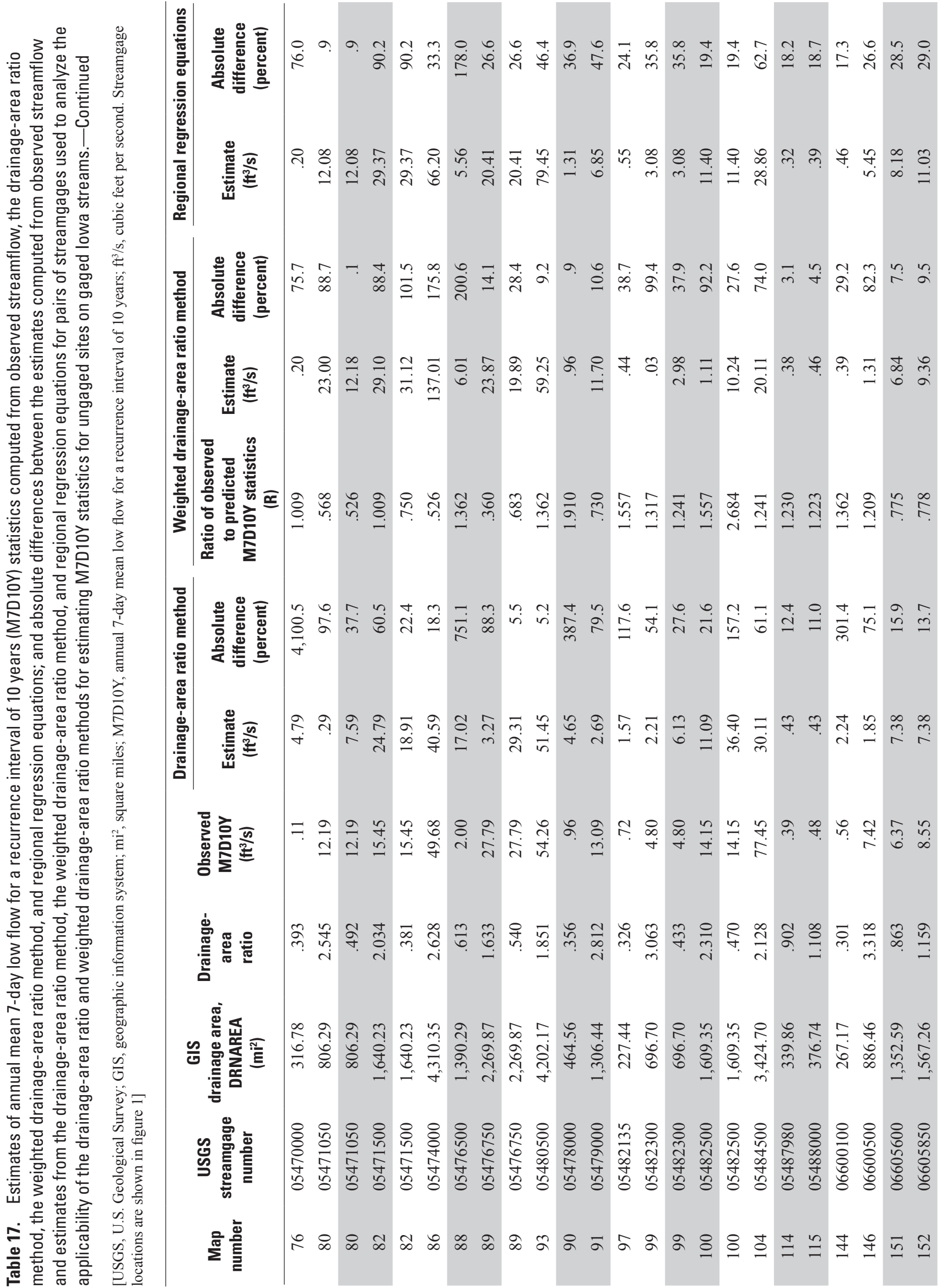




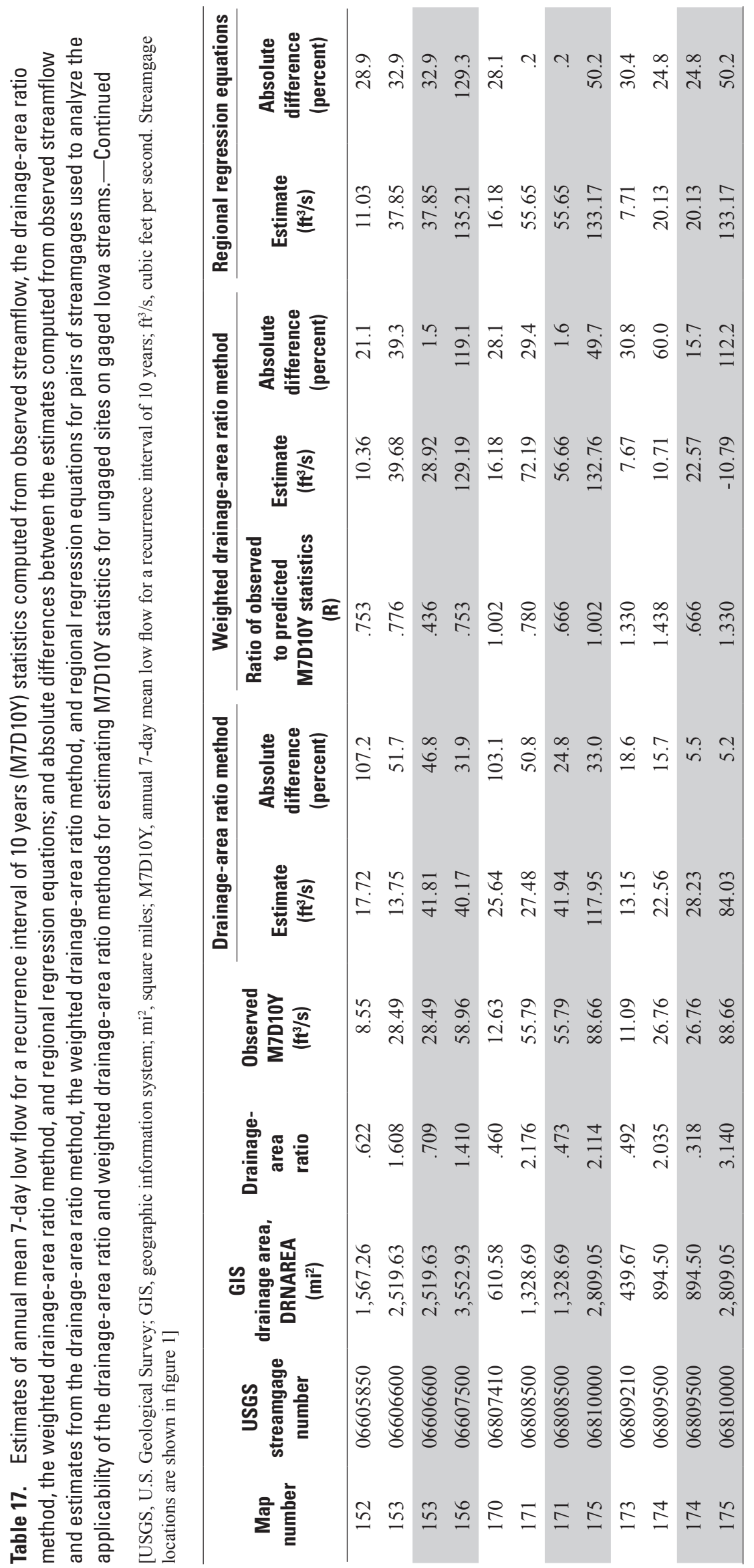


Appendix 1 


\section{Appendix 1. Excluded Streamgages}

Streamflow data from 22 streamgages operated by the lowa Water Science Center were excluded from consideration in the development of low-flow frequency and harmonic-mean-flow regression equations for lowa (table $A-1$, figure $A-1$ ). Twentyone of the streamgages are located on regulated streams, and one streamgage, 06485500 Big Sioux River at Akron (map number 223), has a drainage area that extends outside of the 50-mile buffer used for the study area. Table A-2 lists the same six selected low-flow frequency statistics and the harmonic-mean-flow statistic for these 22 streamgages as computed for all other streamgages included in this study.
The low-flow statistics listed in table A-2 were computed from observed regulated streamflow records using data through September 30, 2006, with the exception of the Akron streamgage for which the streamflow record is unregulated. Because significant positive trends in annual low flows were found when considering the entire period of regulated streamflow record for some of the streamgages listed in table A-1, low-flow frequency statistics and harmonic mean flows were computed for each streamgage in table A-2 using the longest, most-recent period of regulated record without a significant trend in low flow. 


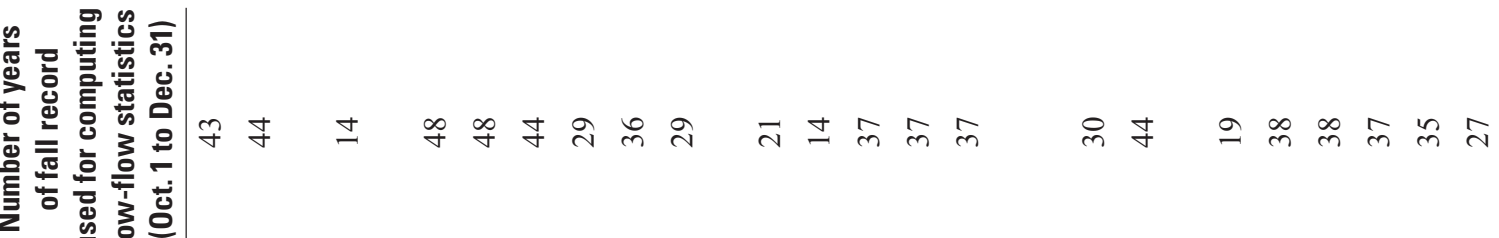
总

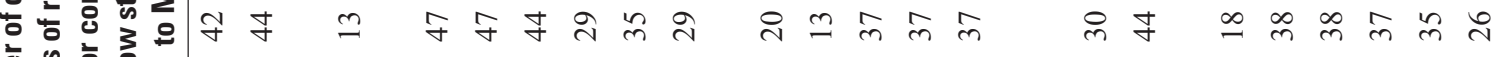

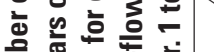

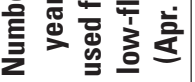

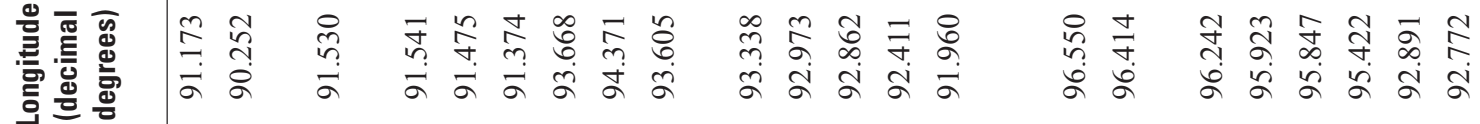
焉造㝝

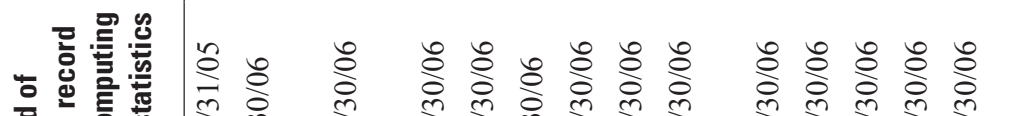

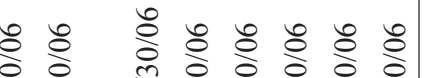

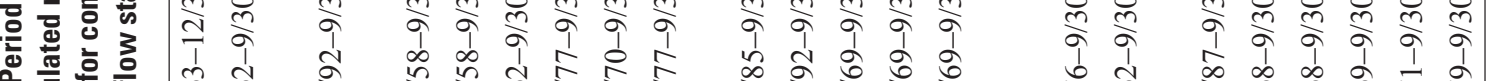

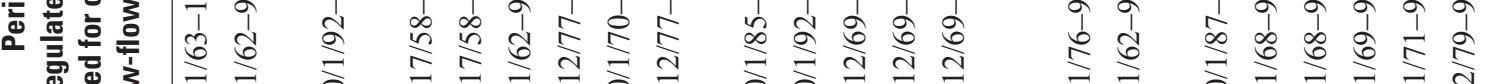

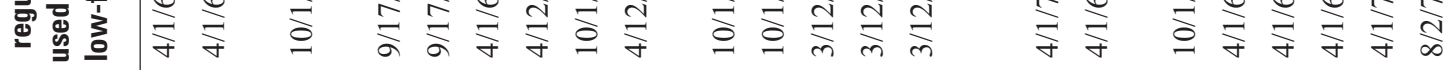

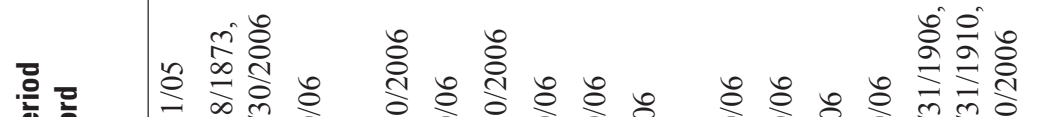

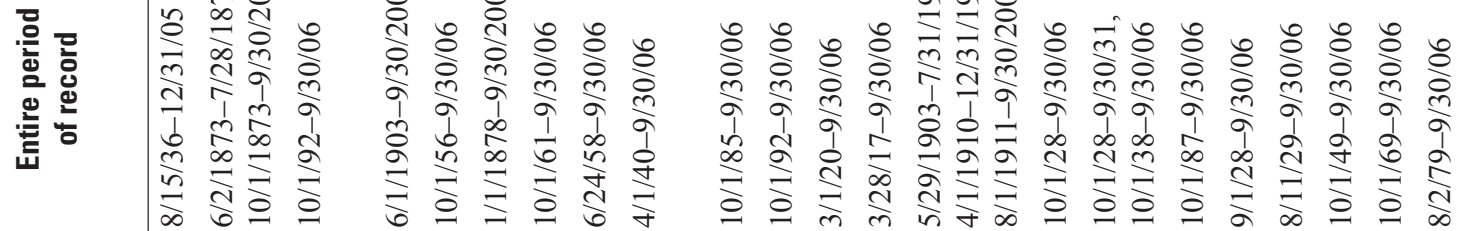

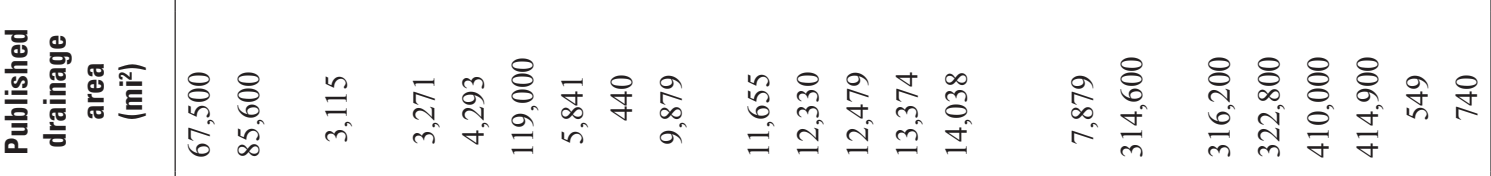
$\sum^{\pi}$

르

$\stackrel{\oplus}{\rightleftarrows}$

亏а

힌

흥

:

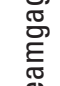

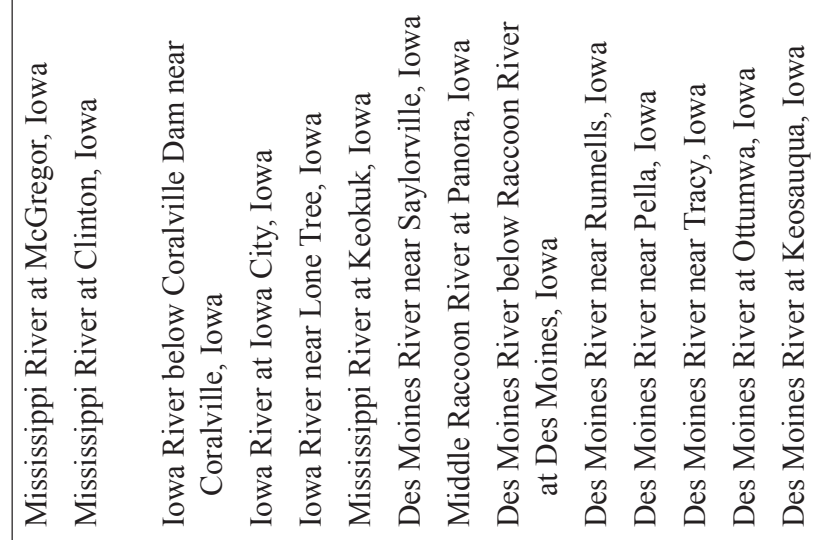

$\frac{2}{3}$ 


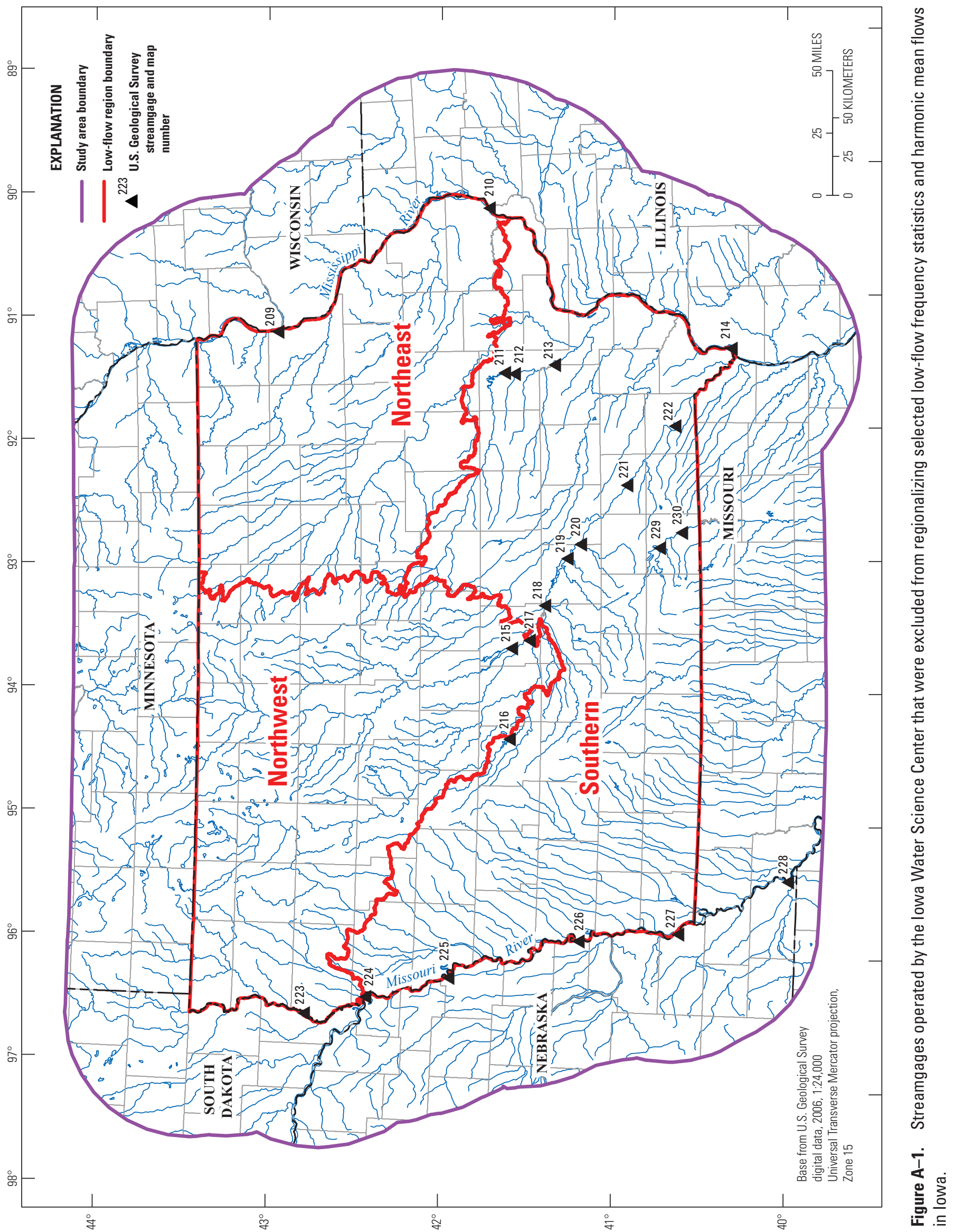


Table A-2. Selected low-flow frequency statistics and harmonic mean flows computed from observed streamflow for streamgages in the study area operated by the lowa Water Science Center that were excluded from the development of regression equations.

[no., number; USGS, U.S. Geological Survey; $\mathrm{mi}^{2}$, square miles; M1D10Y, annual 1-day mean low flow with a recurrence interval of 10 years; $\mathrm{ft}^{3} / \mathrm{s}$, cubic feet per second; M7D10Y, annual 7-day mean low flow with a recurrence interval of 10 years; M30D10Y, annual 30-day mean low flow with a recurrence interval of 10 years; M30D5Y, annual 30-day mean low flow with a recurrence interval of 5 years; M1D10Y1012, seasonal (October through December) 1-day mean low flow with a recurrence interval of 10 years; M7D10Y1012, seasonal (October through December) 7-day mean low flow with a recurrence interval of 10 years; QAH, harmonic mean flow. Streamgage locations are shown in figure A-1]

\begin{tabular}{|c|c|c|c|c|c|c|c|c|c|}
\hline $\begin{array}{c}\text { Map } \\
\text { no. }\end{array}$ & $\begin{array}{c}\text { USGS } \\
\text { streamgage } \\
\text { number }\end{array}$ & $\begin{array}{c}\text { Published } \\
\text { drainage } \\
\text { area } \\
\left(\mathrm{mi}^{2}\right)\end{array}$ & $\begin{array}{c}\text { Observed } \\
\text { M1D10Y } \\
\left(\mathrm{ft}^{3} / \mathrm{s}\right)\end{array}$ & $\begin{array}{c}\text { Observed } \\
\text { M7D10Y } \\
\left(\mathrm{ft}^{3} / \mathrm{s}\right)\end{array}$ & $\begin{array}{c}\text { Observed } \\
\text { M30D10Y } \\
\left(\mathrm{ft}^{3} / \mathrm{s}\right)\end{array}$ & $\begin{array}{c}\text { Observed } \\
\text { M30D5Y } \\
\left(\mathrm{ft}^{3} / \mathrm{s}\right)\end{array}$ & $\begin{array}{c}\text { Observed } \\
\text { M1D10Y1012 } \\
\left(\mathrm{ft}^{3} / \mathrm{s}\right)\end{array}$ & $\begin{array}{c}\text { Observed } \\
\text { M7D10Y1012 } \\
\left(\mathrm{ft}^{3} / \mathrm{s}\right)\end{array}$ & $\begin{array}{c}\text { Observed } \\
\text { OAH } \\
\left(\mathrm{ft}^{3} / \mathrm{s}\right)\end{array}$ \\
\hline 209 & 05389500 & 67,500 & 8,540 & 9,860 & 11,600 & 13,400 & 9,250 & 10,600 & 27,600 \\
\hline 210 & 05420500 & 85,600 & 12,500 & 13,600 & 15,600 & 18,300 & 13,800 & 15,100 & 37,500 \\
\hline 211 & 05453520 & 3,115 & 127 & 130 & 162 & 199 & 118 & 125 & 726 \\
\hline 212 & 05454500 & 3,271 & 99.1 & 106 & 128 & 173 & 140 & 151 & 634 \\
\hline 213 & 05455700 & 4,293 & 128 & 141 & 182 & 240 & 179 & 197 & 875 \\
\hline 214 & 05474500 & 119,000 & 14,600 & 17,100 & 20,800 & 24,700 & 16,200 & 19,600 & 51,700 \\
\hline 215 & 05481650 & 5,841 & 128 & 139 & 150 & 202 & 164 & 190 & 747 \\
\hline 216 & 05483600 & 440 & 14.4 & 13.6 & 17.1 & 25.3 & 15.5 & 17.9 & 63.2 \\
\hline 217 & 05485500 & 9,879 & 190 & 229 & 274 & 392 & 285 & 382 & 1,440 \\
\hline 218 & 05487500 & 11,655 & 334 & 365 & 410 & 540 & 366 & 406 & 1,860 \\
\hline 219 & 05488110 & 12,330 & 241 & 255 & 293 & 403 & 244 & 275 & 1,740 \\
\hline 220 & 05488500 & 12,479 & 231 & 255 & 299 & 411 & 274 & 329 & 1,670 \\
\hline 221 & 05489500 & 13,374 & 97.7 & 266 & 326 & 462 & 142 & 330 & 1,780 \\
\hline 222 & 05490500 & 14,038 & 212 & 310 & 374 & 526 & 251 & 377 & 1,990 \\
\hline 223 & 06485500 & 7,879 & 39.8 & 42.4 & 51.7 & 106 & 71.6 & 84.3 & 302 \\
\hline 224 & 06486000 & 314,600 & 6,390 & 8,620 & 9,720 & 11,800 & 7,950 & 9,750 & 25,000 \\
\hline 225 & 06601200 & 316,200 & 8,470 & 10,100 & 10,700 & 12,100 & 9,390 & 10,400 & 24,700 \\
\hline 226 & 06610000 & 322,800 & 7,650 & 11,100 & 13,400 & 14,900 & 9,850 & 12,100 & 30,100 \\
\hline 227 & 06807000 & 410,000 & 8,930 & 12,300 & 16,000 & 17,800 & 11,100 & 13,900 & 35,700 \\
\hline 228 & 06813500 & 414,900 & 10,500 & 13,100 & 16,900 & 18,900 & 13,700 & 15,400 & 38,100 \\
\hline 229 & 06903900 & 549 & 5.99 & 10.5 & 11.1 & 12.3 & 10.6 & 12.0 & 37.4 \\
\hline 230 & 06904010 & 740 & 15.9 & 19.3 & 19.6 & 21.3 & 15.2 & 15.5 & 68.4 \\
\hline
\end{tabular}


Publishing support provided by the:

Lafayette and Rolla Publishing Service Centers

For more information concerning this publication, contact:

Director, USGS lowa Water Science Center

P.O. Box 1230

lowa City, IA 52244

(319) 337-4191

Or visit the lowa Water Science Center Web site at: http://ia.water.usgs.gov 



$$
\text { 䞤 }
$$

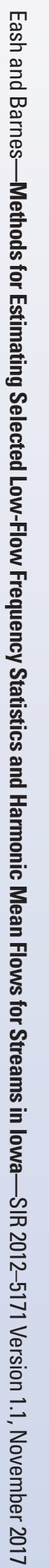

